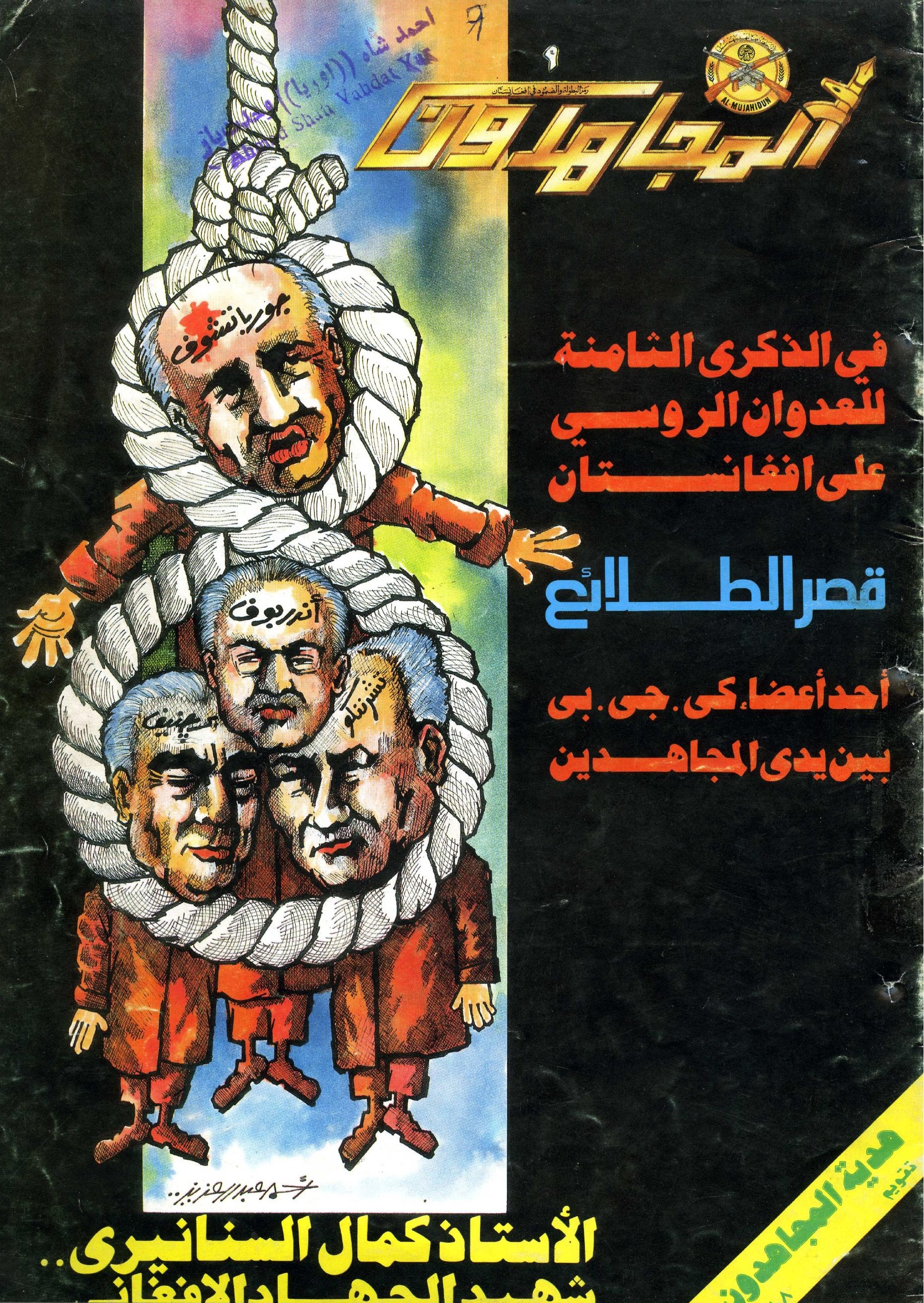




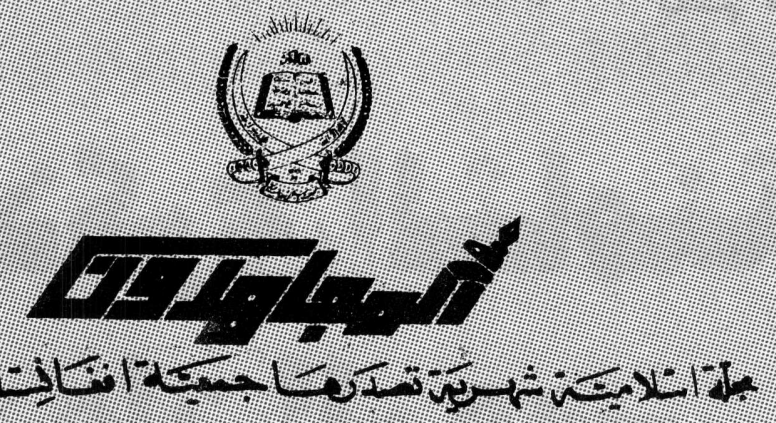

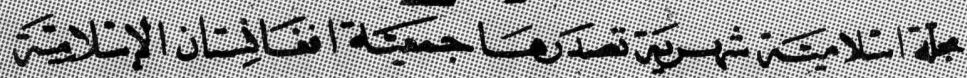

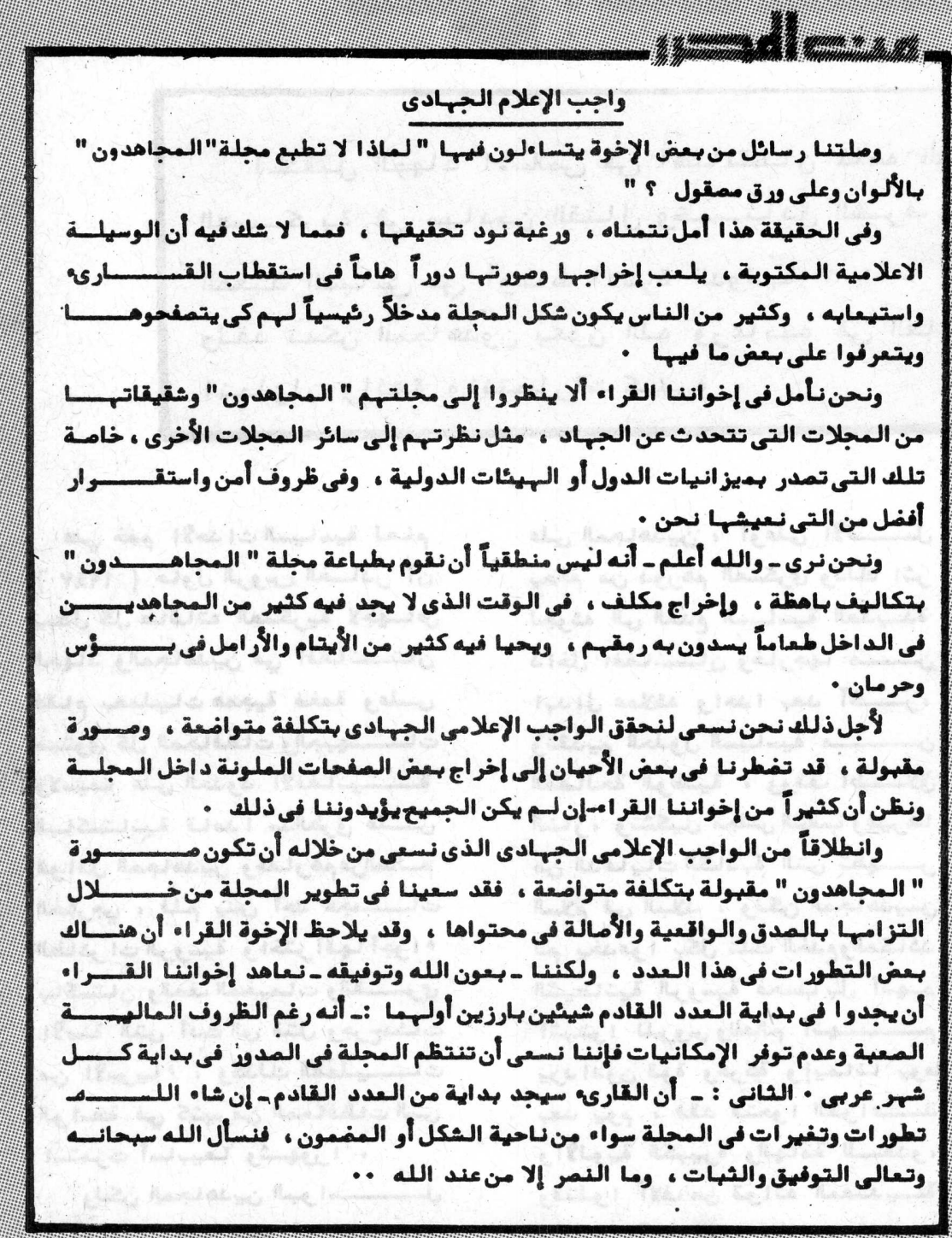

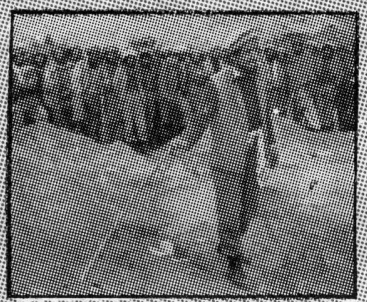

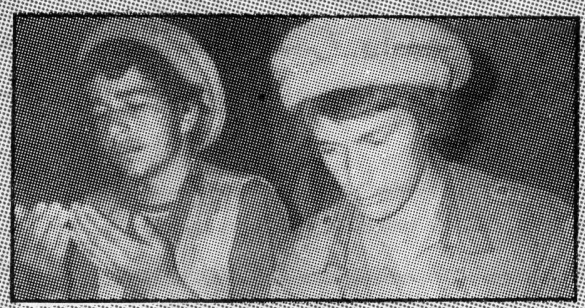

9

HIF

T is

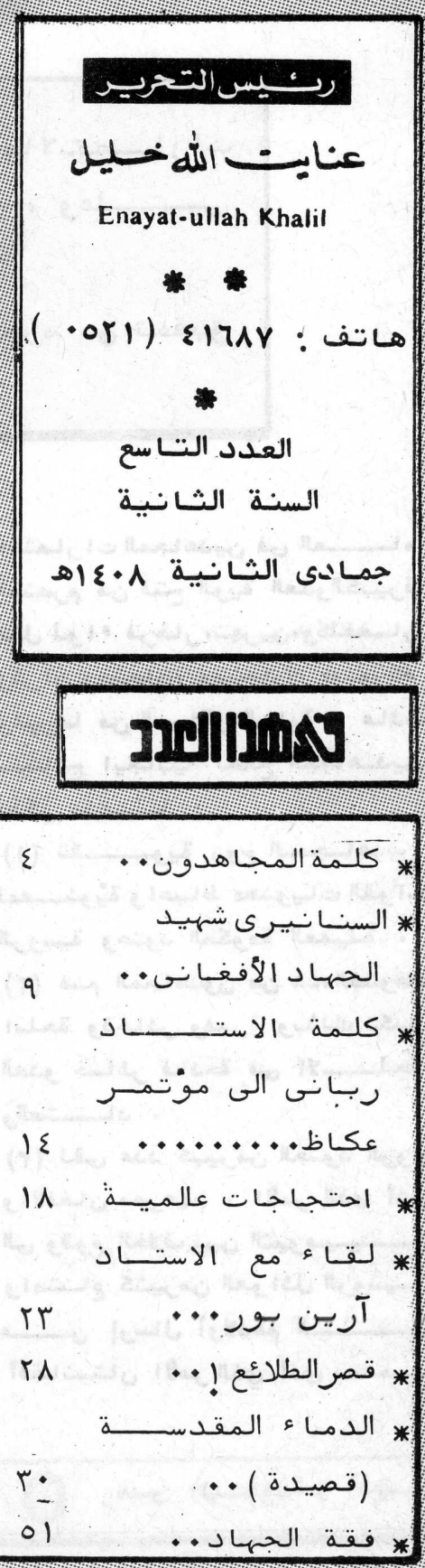


بقلم عنـايت الله "خليل"

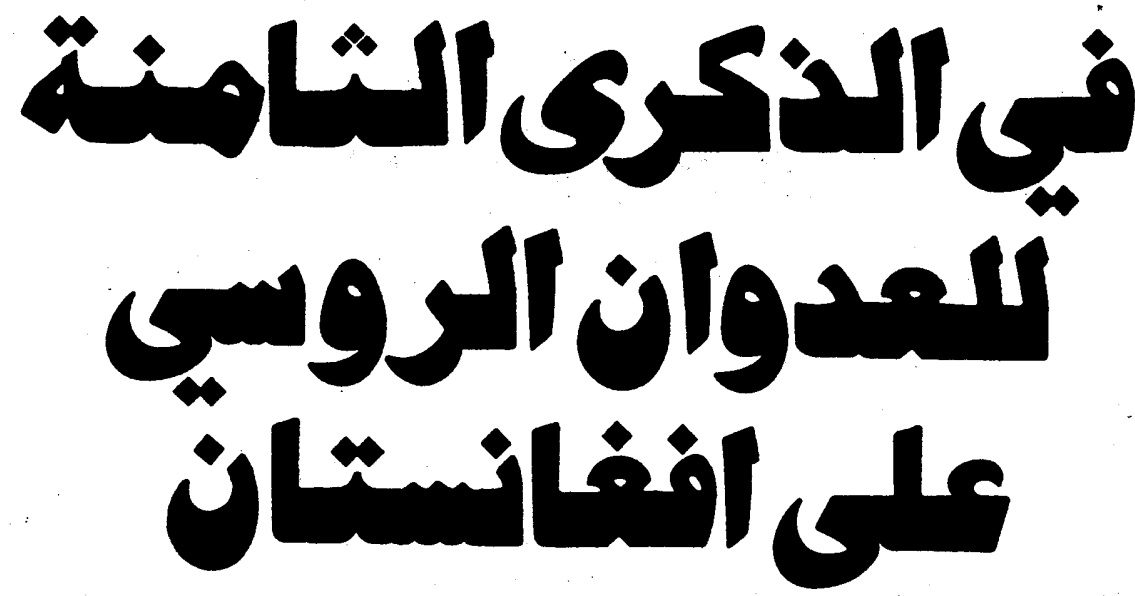

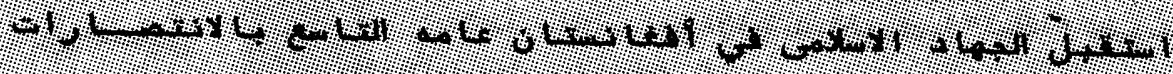

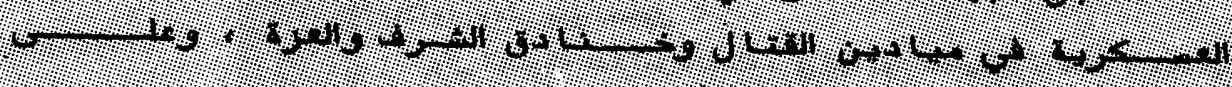

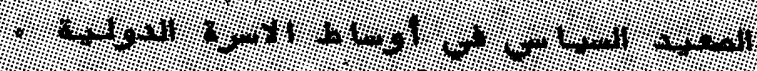

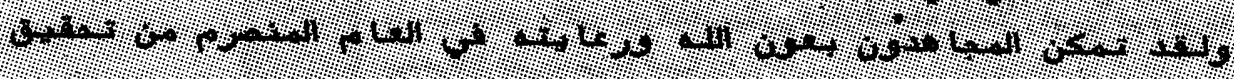
U:

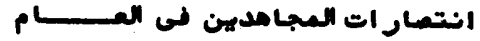

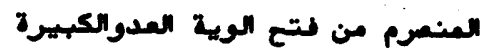

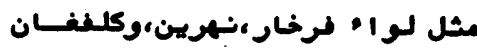

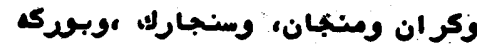

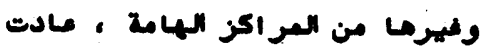
بنتامج ايجابية لماكع المبامديدين : مدكر منهــ

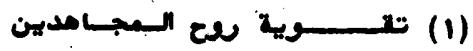

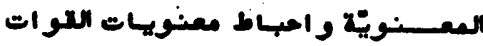

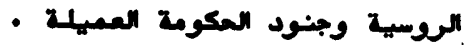

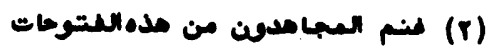

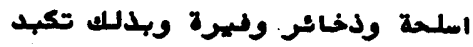

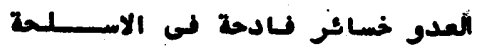

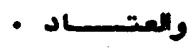

وامد (r) لتى عدد كهيرمن الجنود الورس

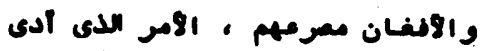

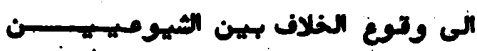

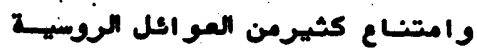

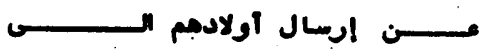

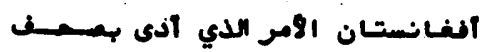

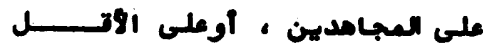

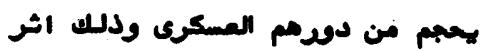

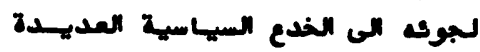

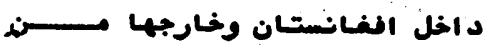

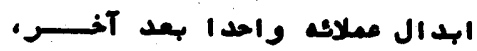

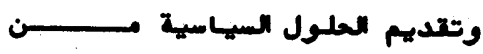

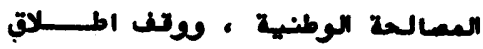
النار ب وتشكيل مجلس لمشعب ومهيره

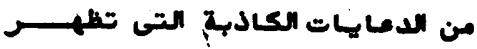

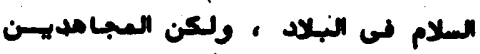

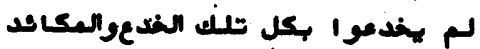

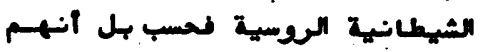

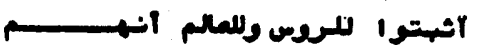

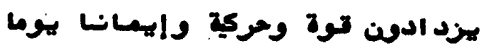

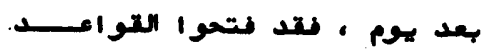

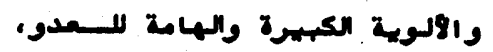

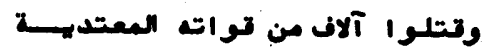

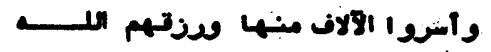

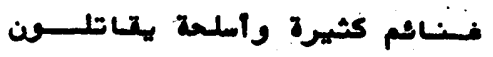

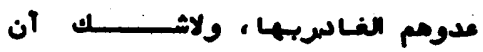

كلي خغم ال8حد اث السياسية لعام

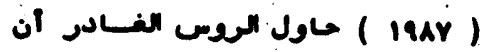

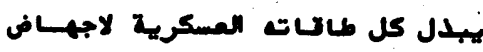
الجهاد والشجاهدين في الففانسستان

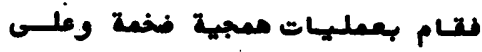

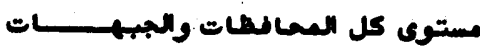

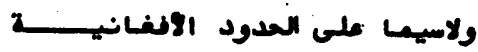

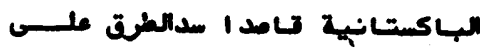

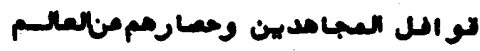

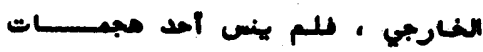

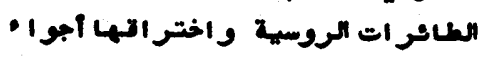

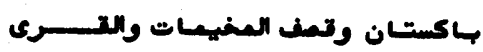
الومنح التى أدت الى قتل وجرعبشات

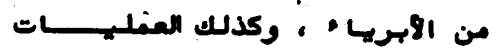

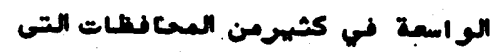

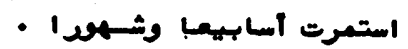

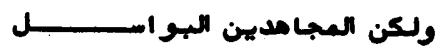

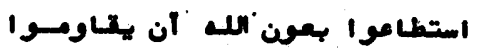

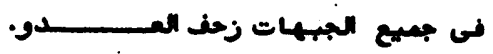

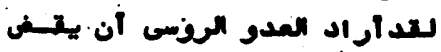

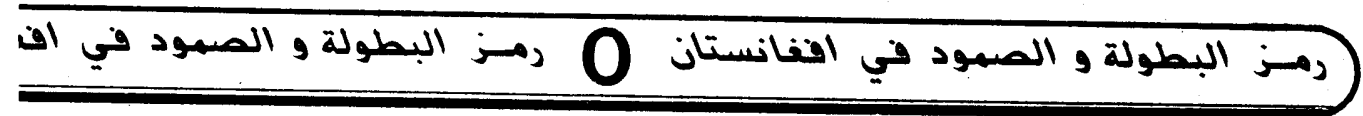

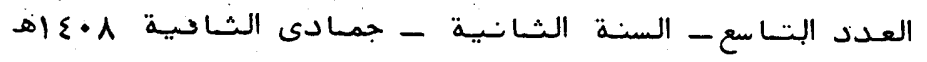

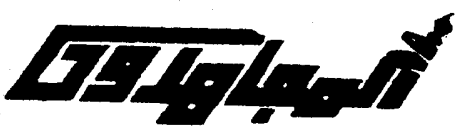




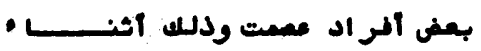

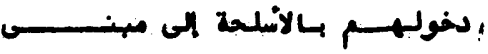

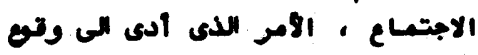

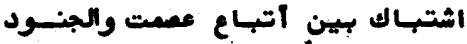

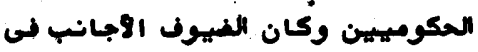

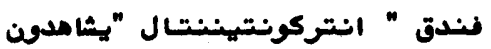
الاحد اث وتد قتل خلال مذا الاثتبهال

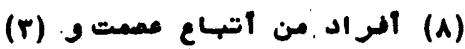

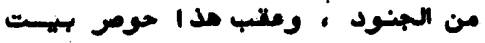

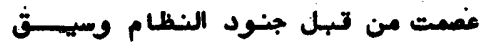

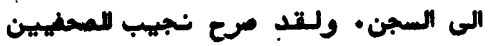
أن مصمت كان قد الدمن على ولى الخمسر

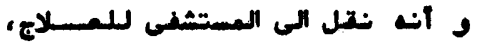

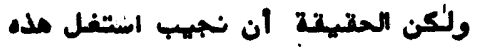
العرمة لفرب عممت الذي كان خمسطاً

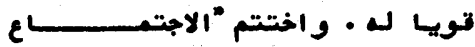

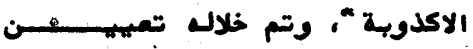

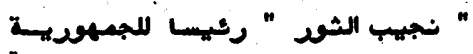

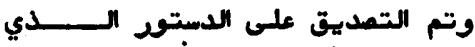

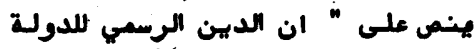

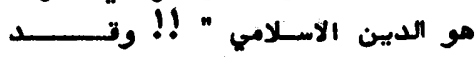

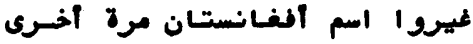

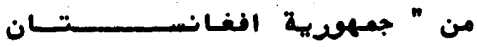

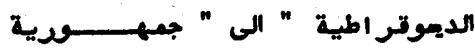

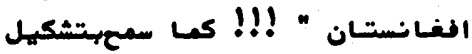

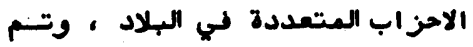

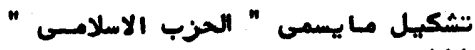

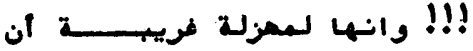
يدعي نطام كابل الشيوعي الاســلام

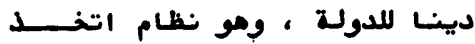

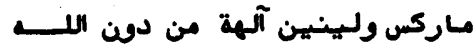

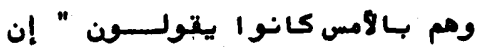

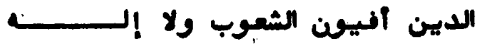

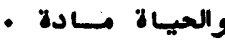

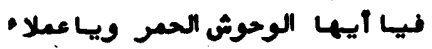
الكرملهين لتد مركمم شعبالفانستان

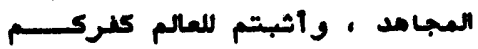

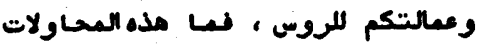

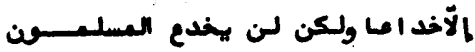

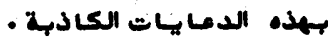

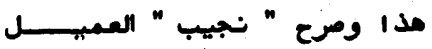

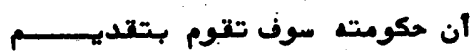

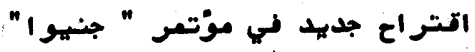

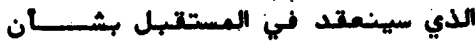

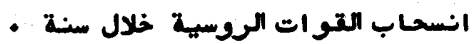

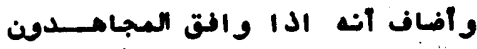

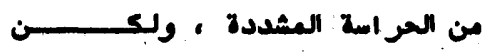

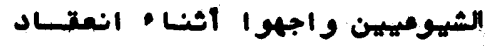

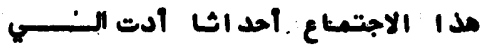

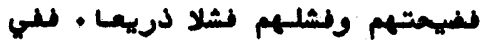

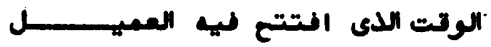

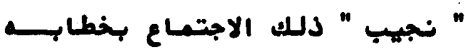

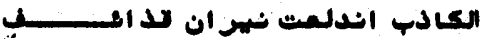
السبامدهن ، ومزت الصواريسغ موتحع

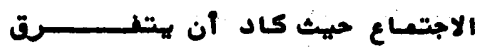

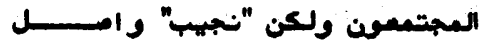

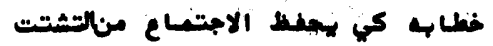

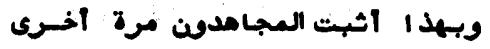
العالم أن الحكومة العميلس وأسيًادها.

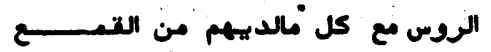

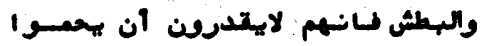

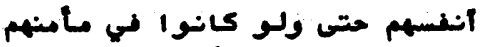

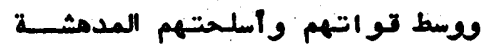

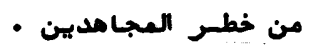

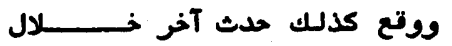
الاجتماع وأدى الى فضيحة الثيـوعيين

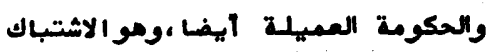
العنيف الدي وقع بين جنود الحكومة

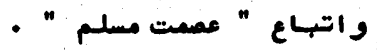
من هو .عصمت مسـلـم ?

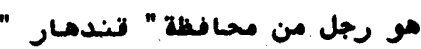
سمى نلسه مجامدا لترة من من من الزمسن

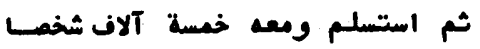

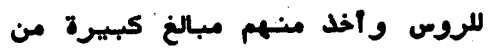

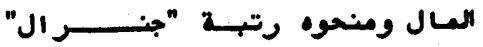

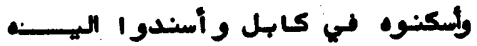

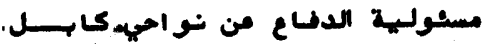

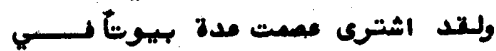

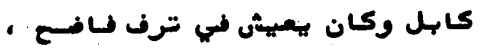

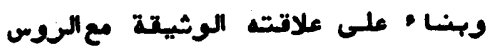

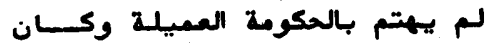

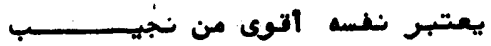

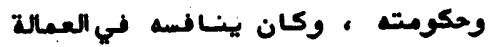

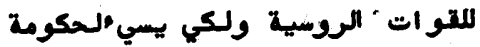

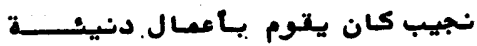

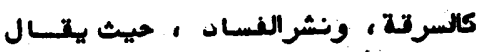

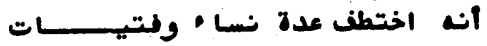

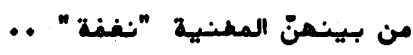

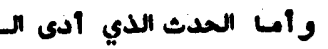

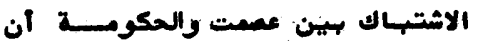

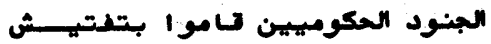

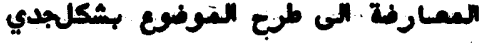

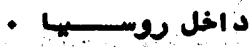

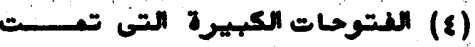

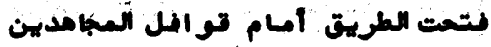

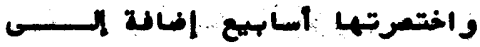

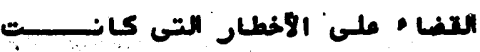

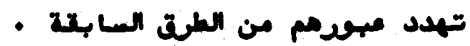

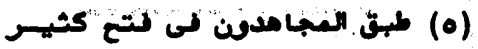

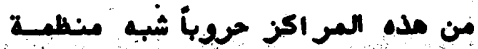

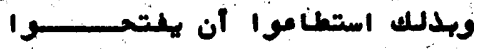

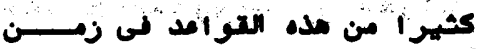

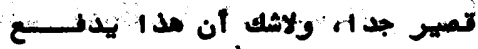

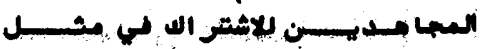
هذه العملميات هروع مالهي و واطمفنان

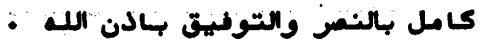
(1) والامم من كل مادكر أن مسله

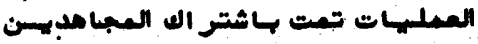

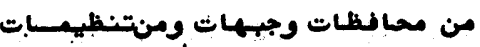

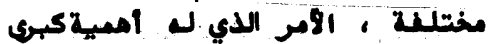

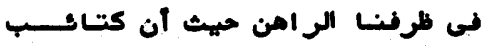

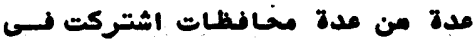

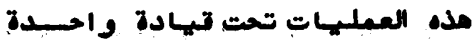

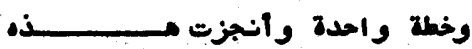

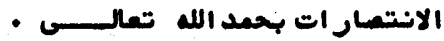

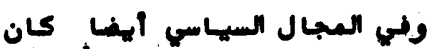

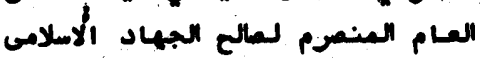

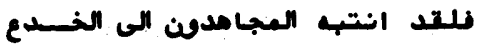

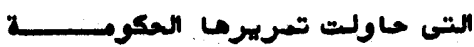

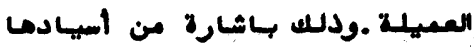

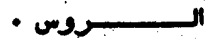

مـجلسي الشعب وفضائَح الشيوعيـة أوعزت الامعريالية الروسية لسي

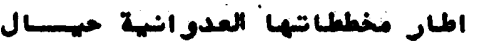

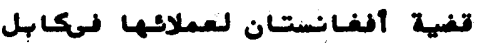
ولمي متدمتهم " نجيب " العميل أن

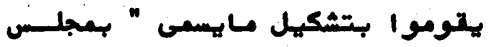

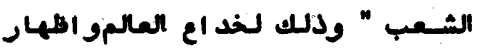

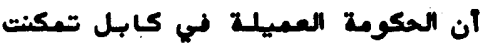

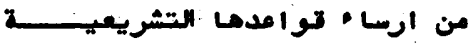

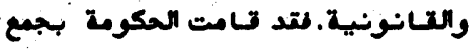
عدد من الشيوعيين ، 'ومدد كبيرمن

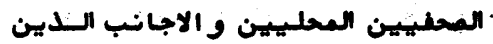

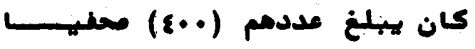
لتغطية الاجتماع العنوف لي أواخر

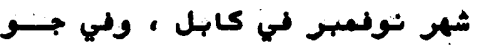




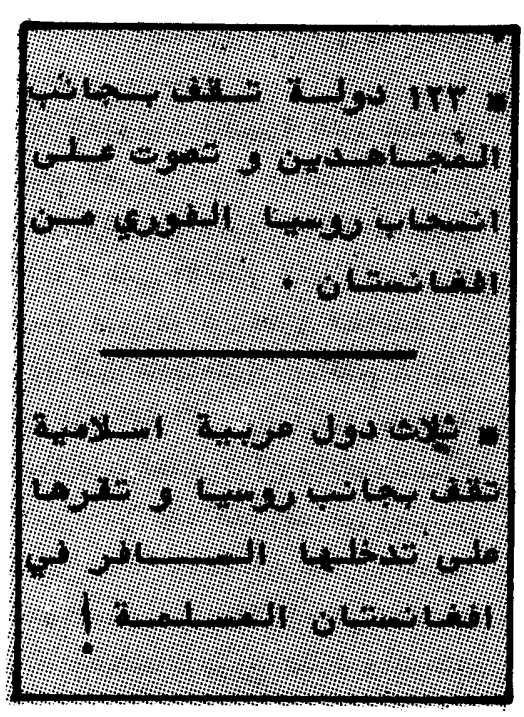

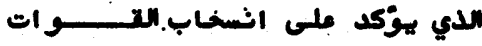

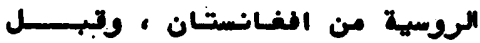

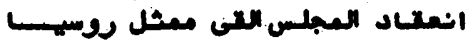
في اوم المتحدة خطابـ كال فيـ

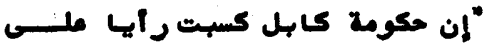

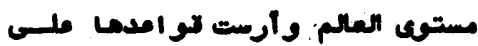

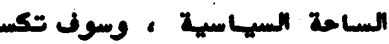

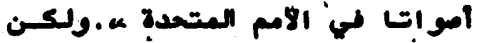

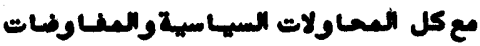

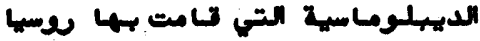

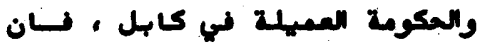

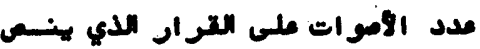

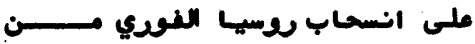

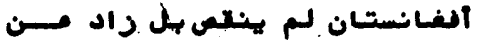

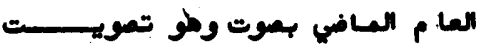
دوبل " هوتان " التي كان لـهارأيا

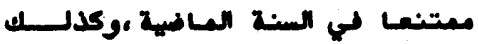

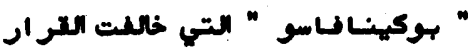

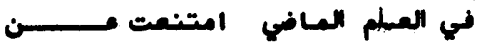

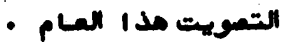

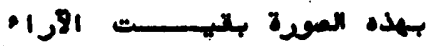

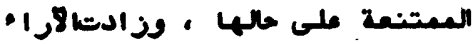

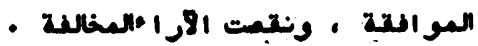

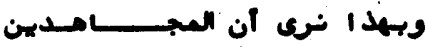

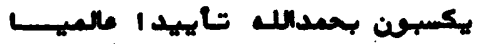

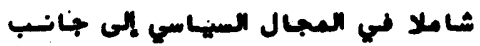

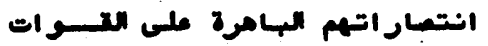

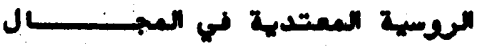

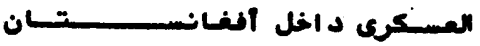
وفي خنسادق الجهاد الاسلامى المبارل.

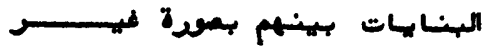
قانونهة ، وأن رجال الحزب الششيوعي

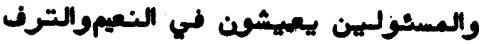

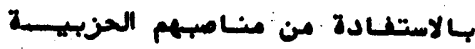

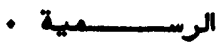

أفغـانستـان في الأمم المتحدة :

و اجهت روسيا والمكومة العمنيلـا

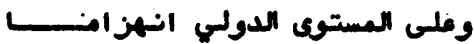

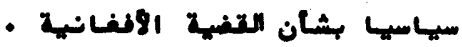
كلي الاجتماع الدي عقدت

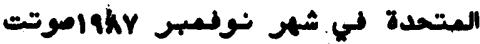

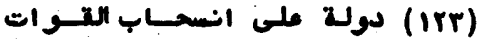

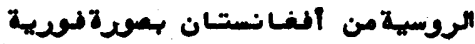

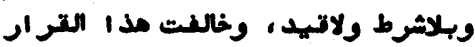

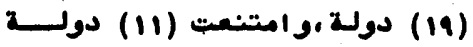

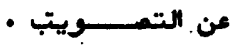$$
\text { الدول المخالفـــة }
$$

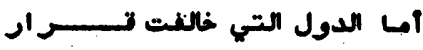

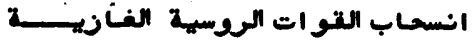

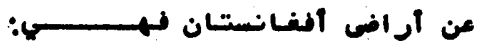

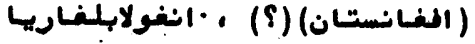

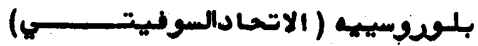

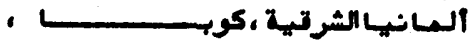

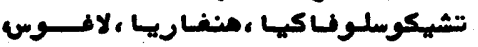

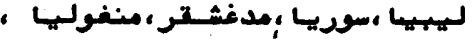

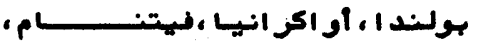
والاتحادالسوفيتي ، اليمن الجنزبي رالمبشة .

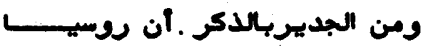

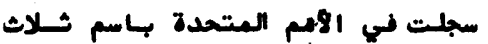

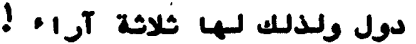

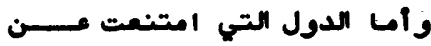

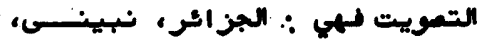

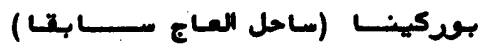

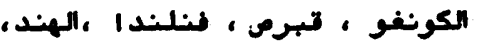

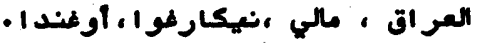

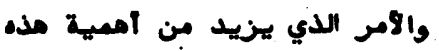

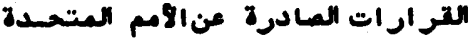

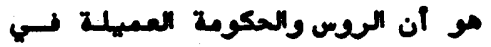

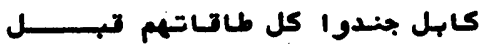

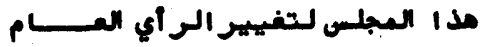

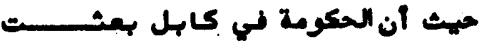

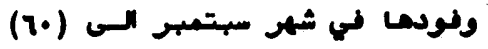

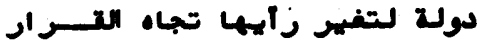

على وتف إطلاق التنر سيتمتالانسحسباب

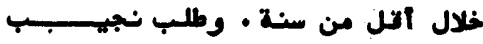

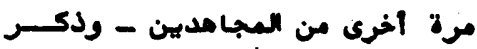

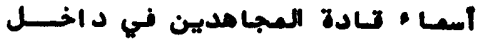

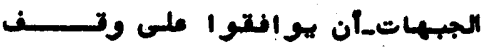

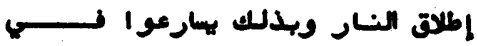

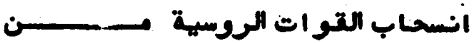

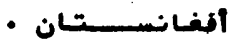

الر أي العالم في روسينا :

اثشارت الاحمافيات الرسميح لتي

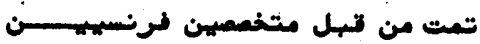

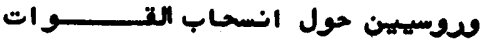

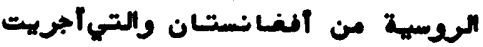

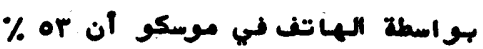

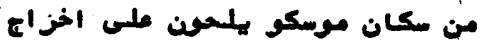

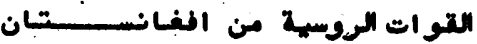

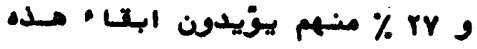

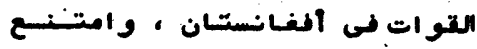

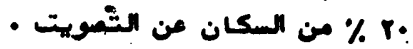

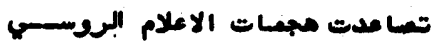

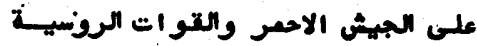

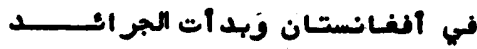
والصحف العوسية تكتب أثيا • لم تكن

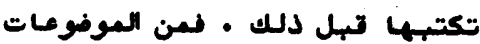

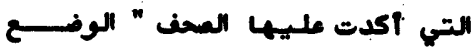

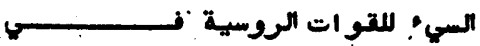

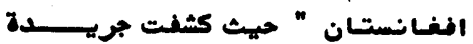

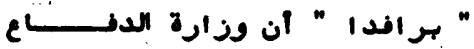

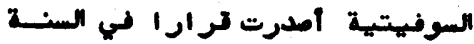

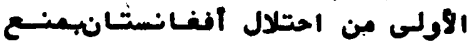

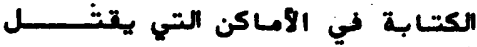

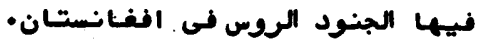

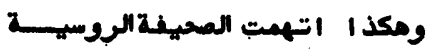

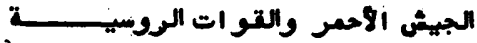

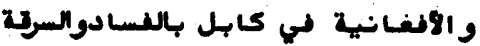

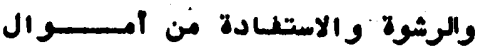

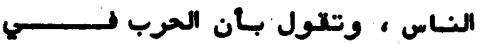

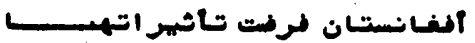

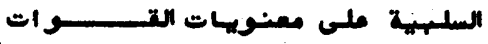

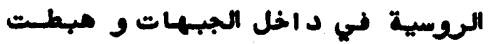

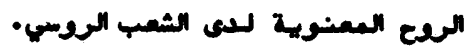

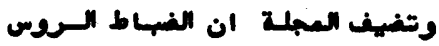

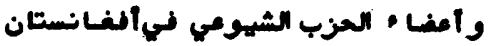

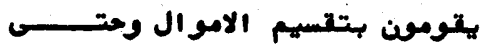

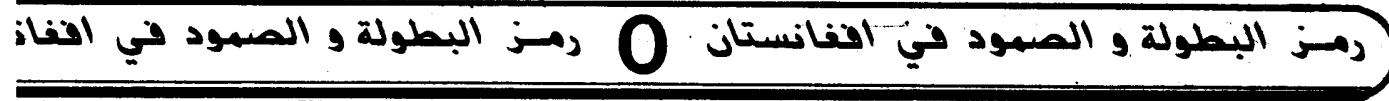




\section{متانص عن}

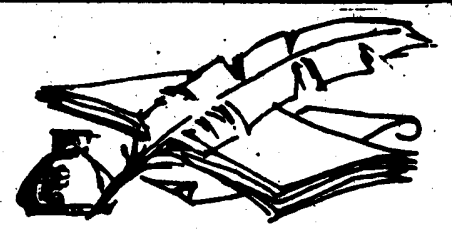

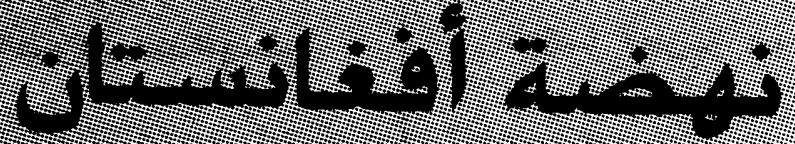
الاسبالانية

د اخل اففانستـان وخبارجهـــــ

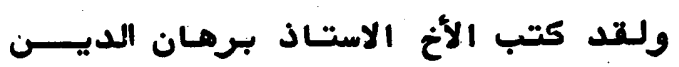

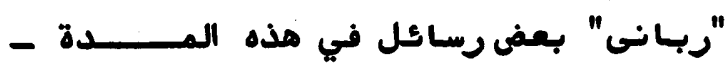

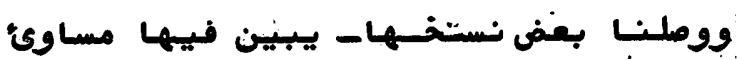

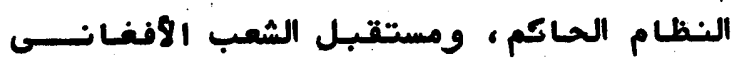

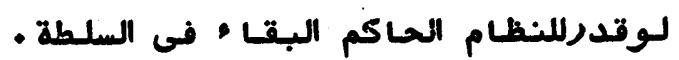

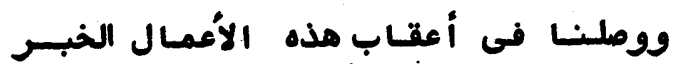

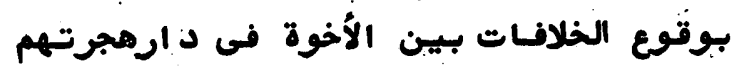

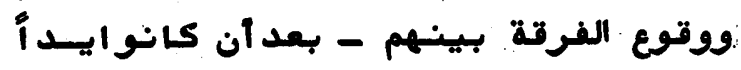

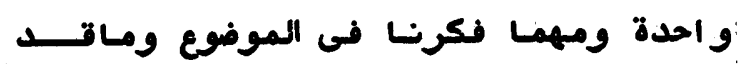

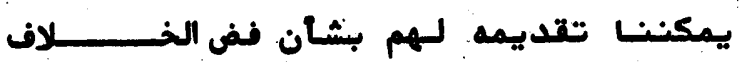

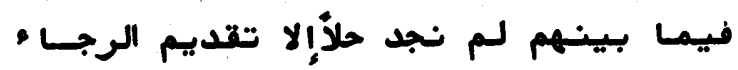
لههم وإطهار مزيد فروتنالـهم على تنسازئم

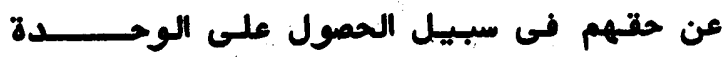

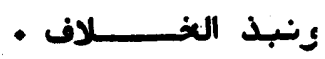
وكلـمـا مرّالزمن أتسانس الجز عن استحنام

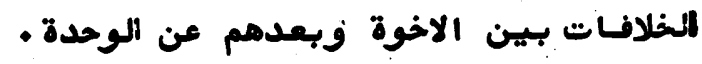

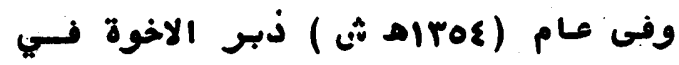

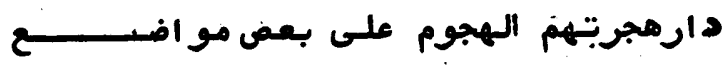

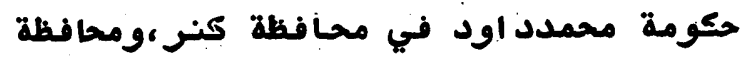

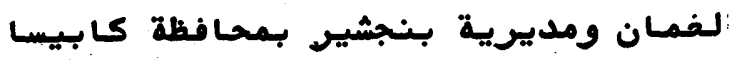

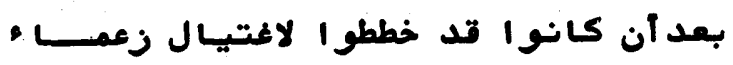

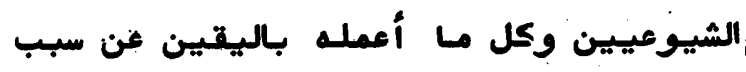

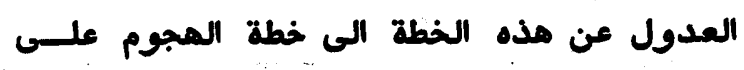

لـقد كتبنـا فى مـامضى أن النهضة بهجرة

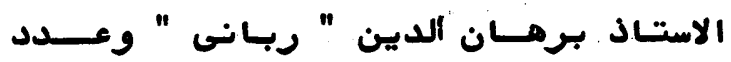

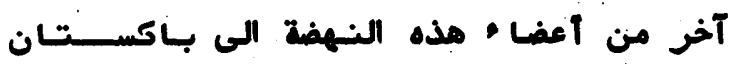

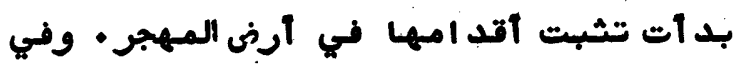

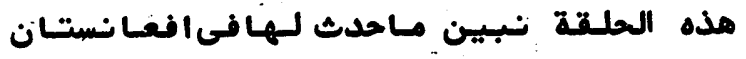

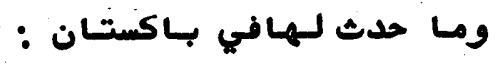

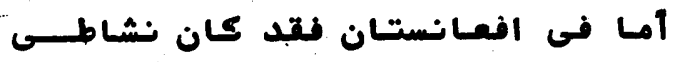

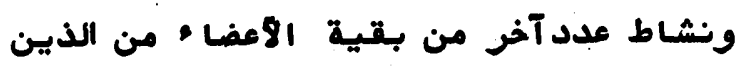

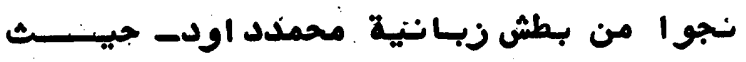

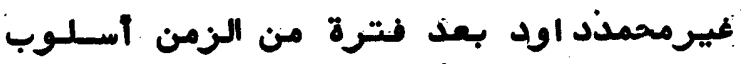

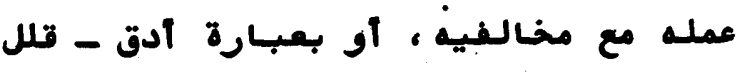

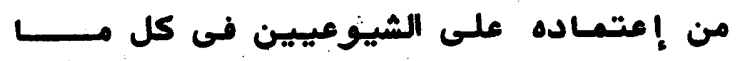

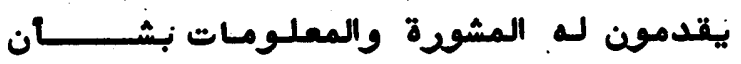
القضا • على خصومهم - بـتلخم فى مـابـاتى:

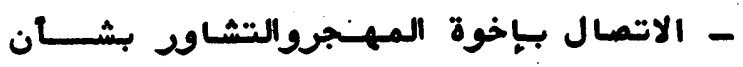
- بعض الأمسور

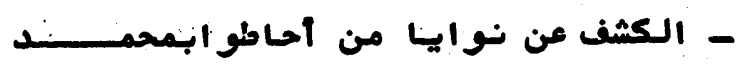

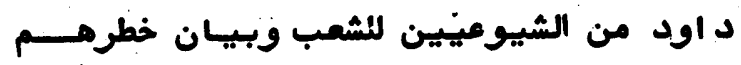

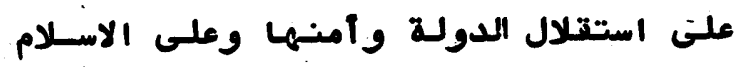

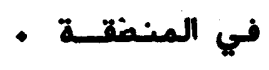
- الاجتماعات المسرية القلِيلة وبعدن قليل

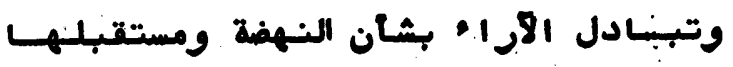

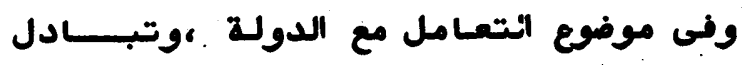

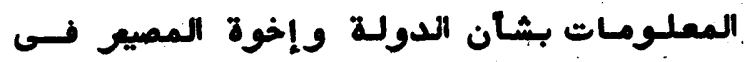

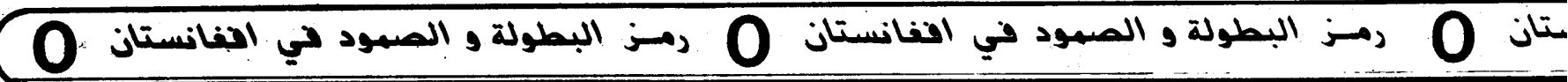




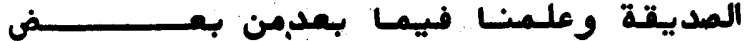

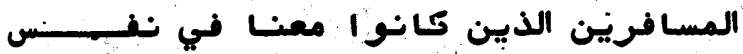

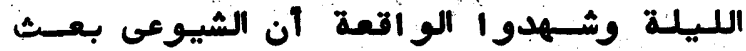

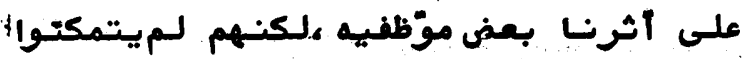

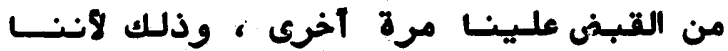

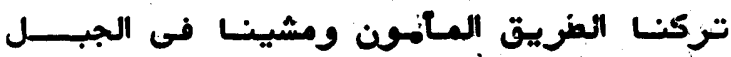
حتى الصباع والى أر اضى باكستان

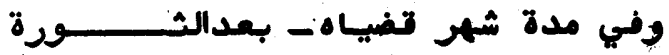

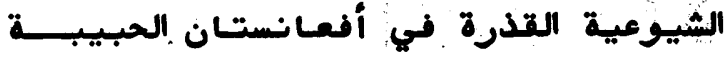

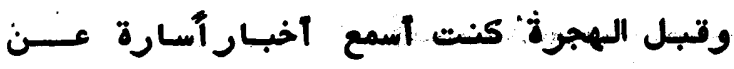

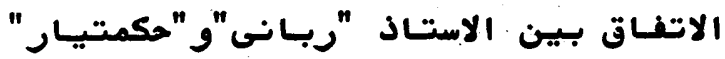
وعن تمثيرة عدد الفد ائيين،ووكثرة الســلاح

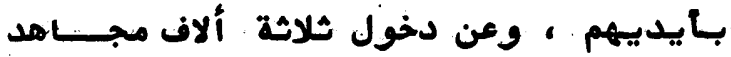

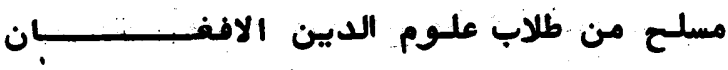

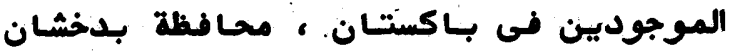

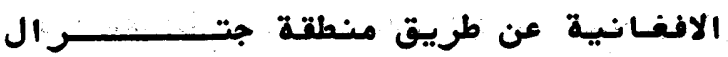

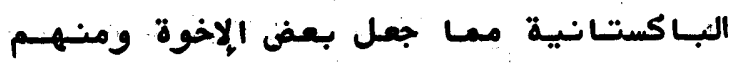

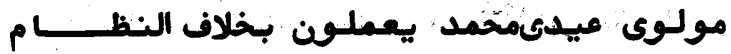

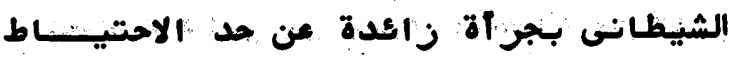
فانه كان يتصور هجوم المجاهدين القريسب

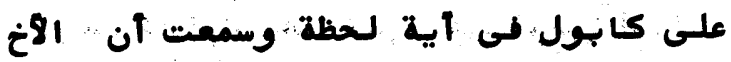

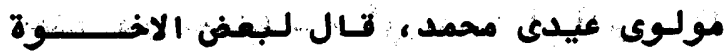
بعدالقبف عليه وتعذيبه تعذيبا ثـديبا:

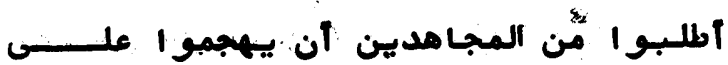

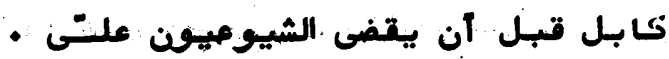

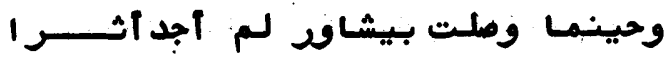

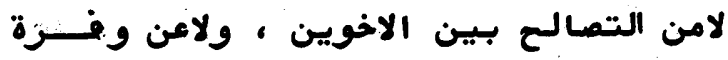

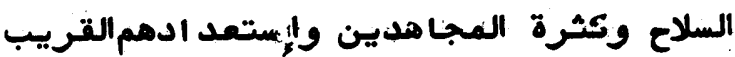

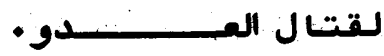

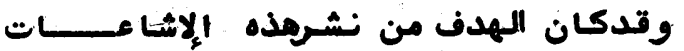

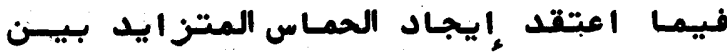

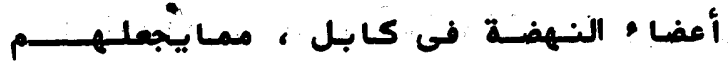

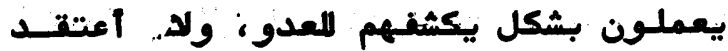

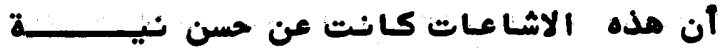

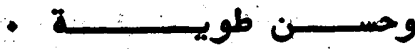

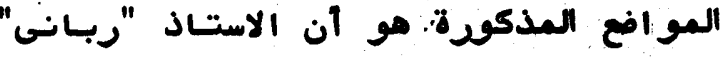

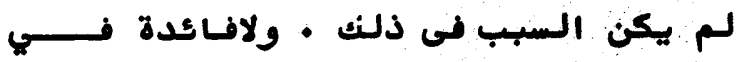

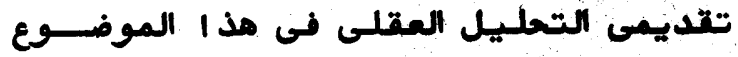

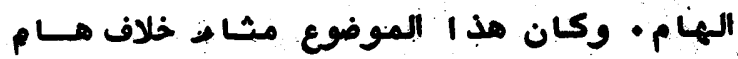

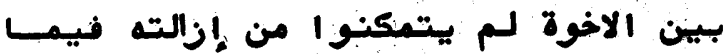

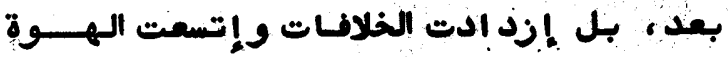

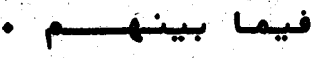
وقد إتمل بى أحد :من الاخوة يسألنـــى

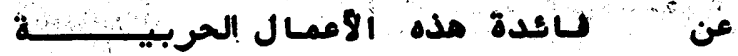
ضدالحكومة محمدد اود،وكان ردى بعد تامل

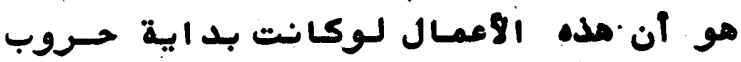

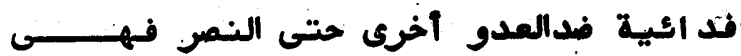

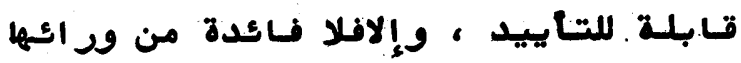

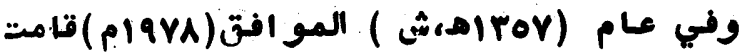

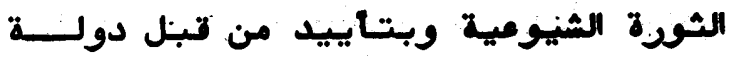

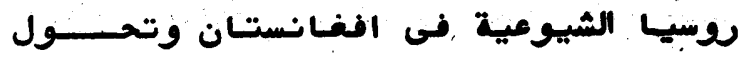

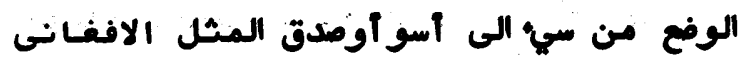

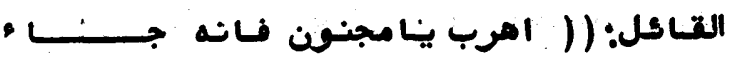

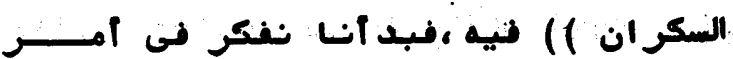

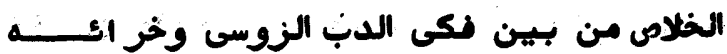

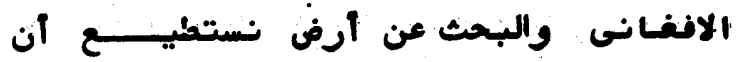

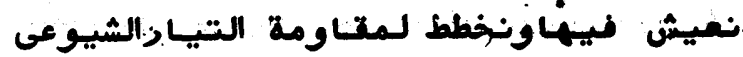

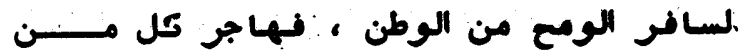

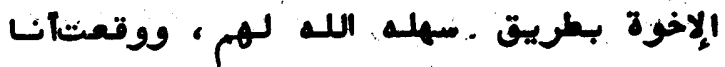

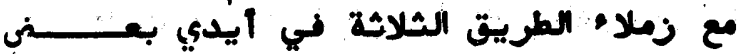
الحكوميين كان كبيرهم. شيوعيا ،وبعدنقاشي

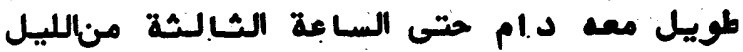

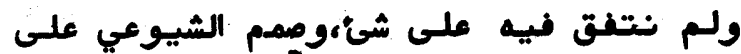

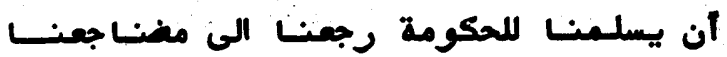

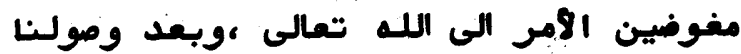

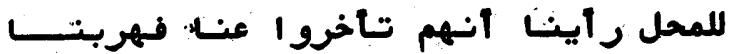

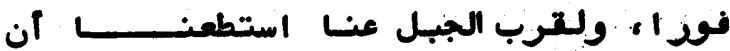

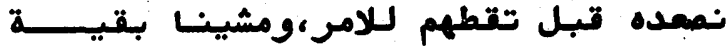

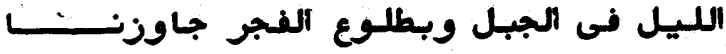

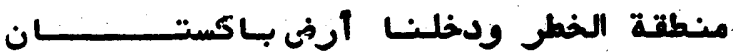


السجون ، وثللو ا يكيلون لـه العذاب ،حتـى

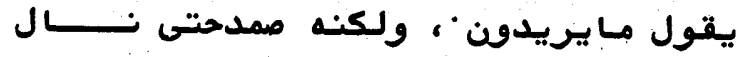

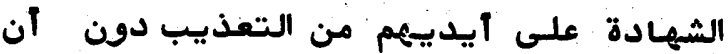

ينـالوا منه شيكا ، وكانت تهمتهنه الرئسية

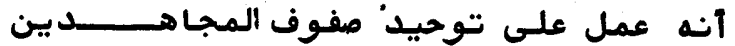

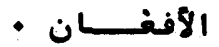

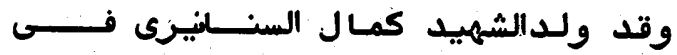

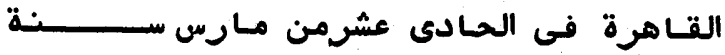

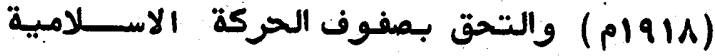
فى أواعل الأربعينيـات ، وكان مقربـا من واهن

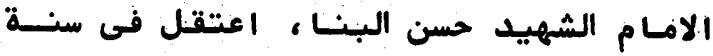

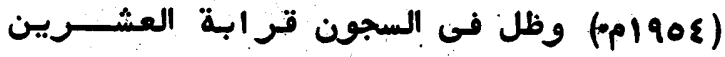

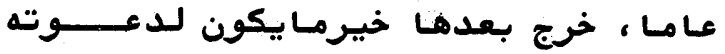
وإخو انه ، كان متزوجا من السيدة أمبينة

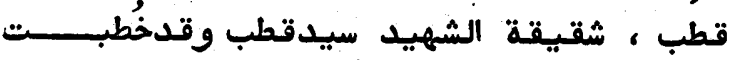

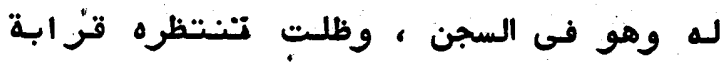

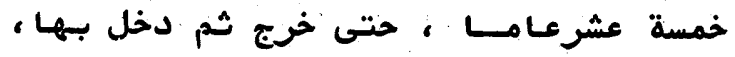

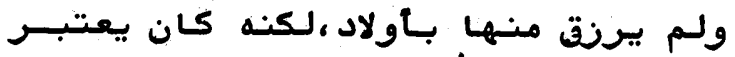
شبـاب الاخوان كلههم أولاده

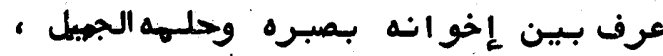

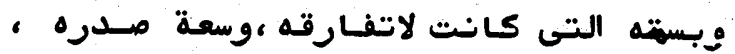

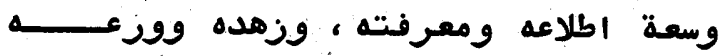

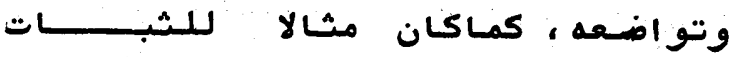

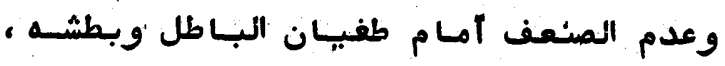

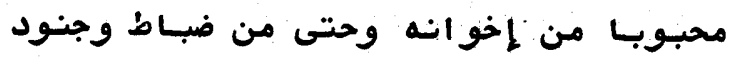

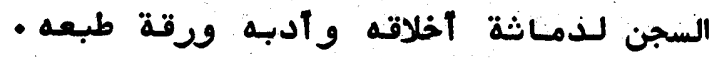

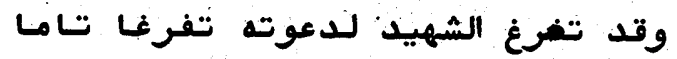

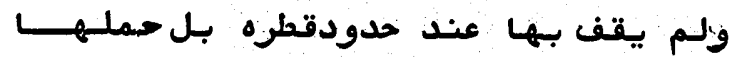

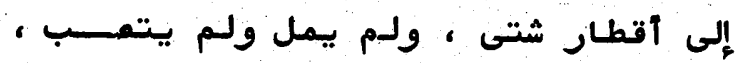

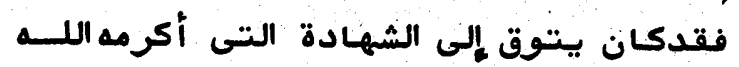

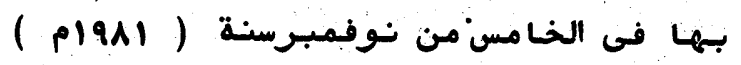

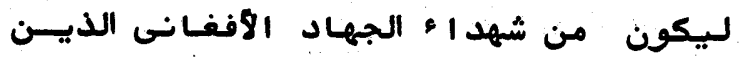

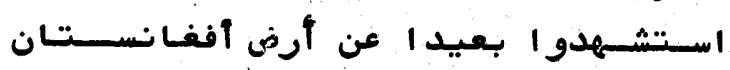

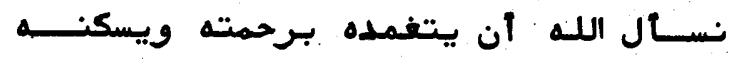

أحمدالكاتب

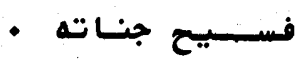
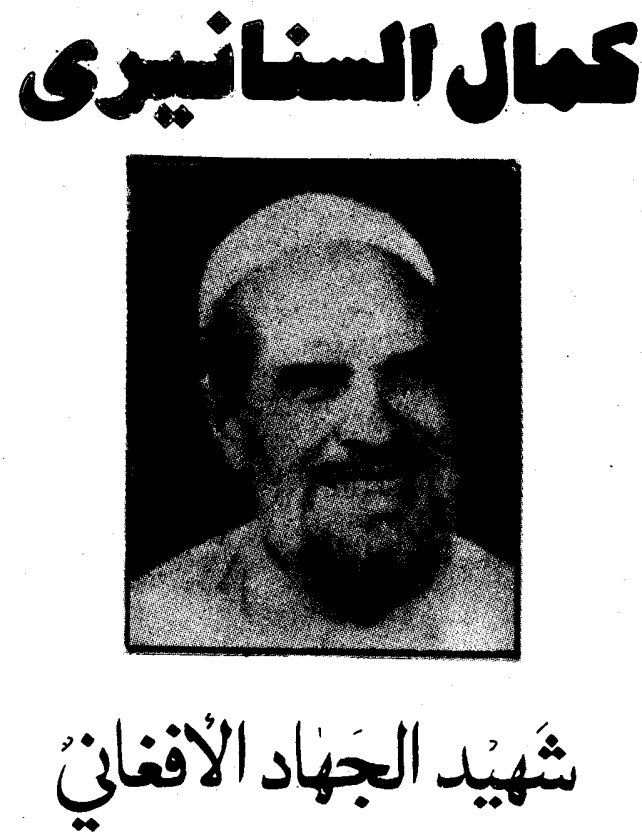

قلبيل هم هولا \& الرجـال الذبن يعملونفن

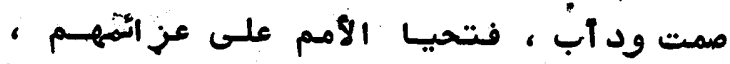

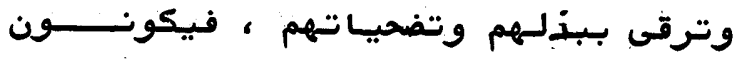

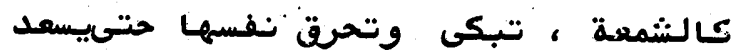
- غيرها بالنور وروية الطريتة

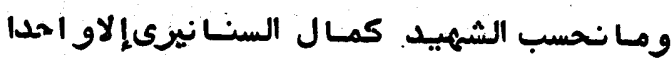

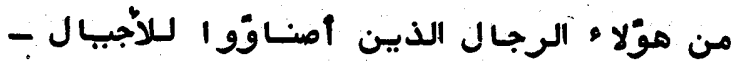

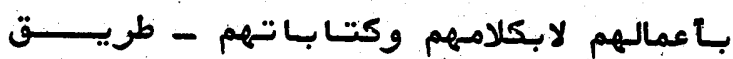

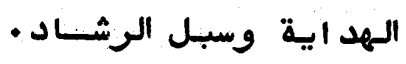

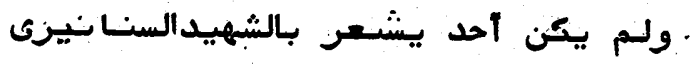

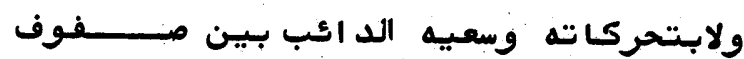
قادة المجاهذينهرغم أنه كانت تنمرعليـه بعض · الايـام دون نوم أور احة ،ولكن الرجل

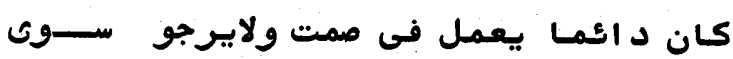

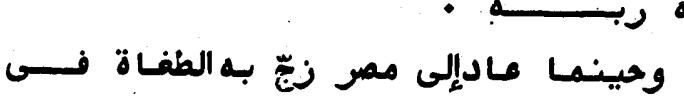


بقلم : ع • ابوعبــــــــ

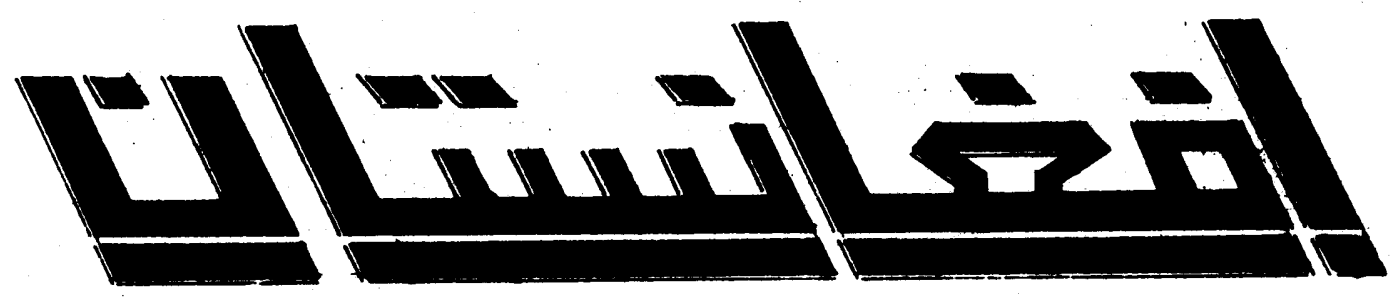

\section{بين أنياب الأعداء و ملفات الأمدقاء}

الحلـقة الثانية

موقف سلبيا أكثر من كونه ايبـابيــــ و أكثر من ذلك فـان هذه الدول لـم تتمكين

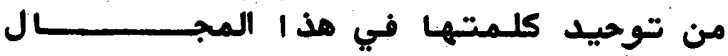

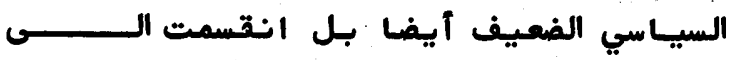

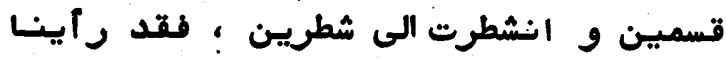

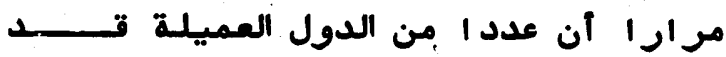

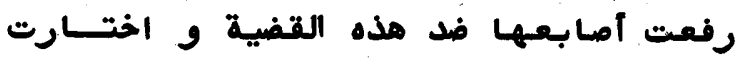

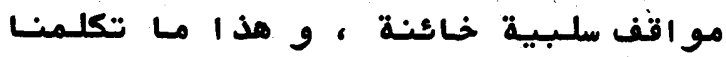

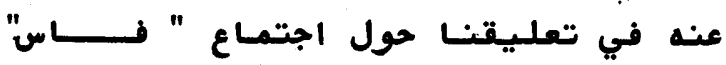

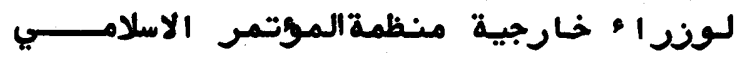

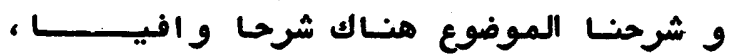

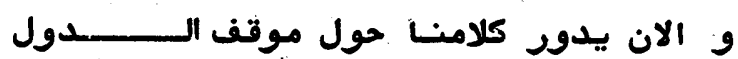

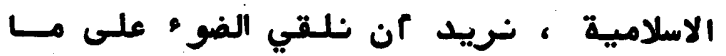

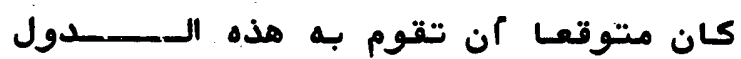

كنـ نـتوقع من جميع الدول الاسلاميــــة 'ان لا تكتفي بهذا الدور السلسبي و هو رفي الامابع في جَّ من التوتر العصبي و الخوف

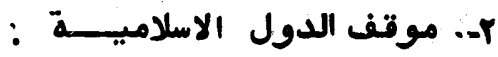

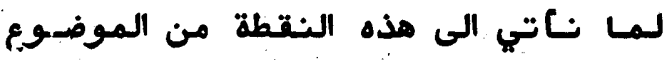

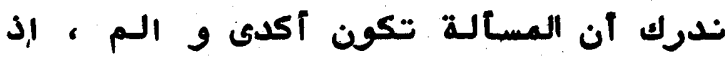

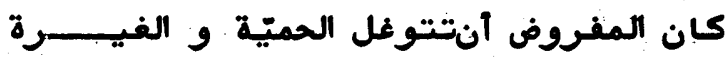

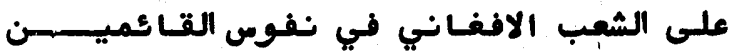

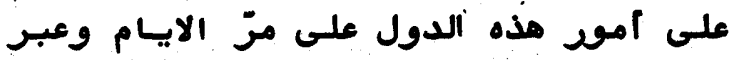

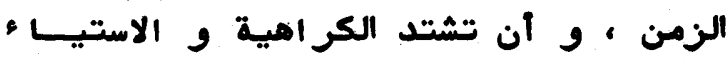

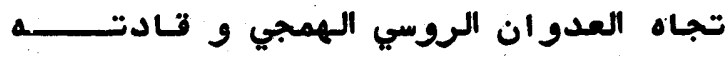

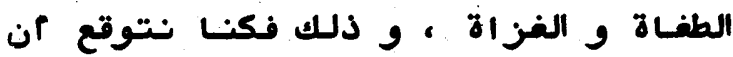

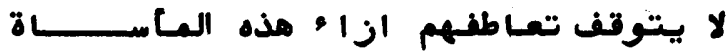
البشرية في هذه الحقبة من المزمن على رفع

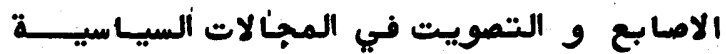
و في تاروقة الموتمر ات و المنـاسبـات لانهم

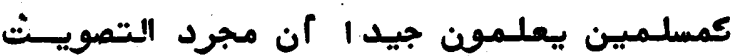

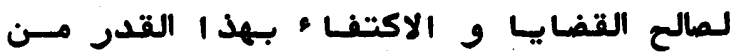

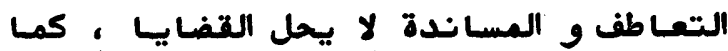

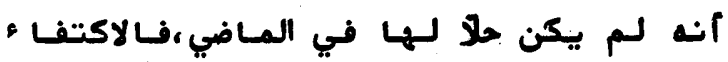

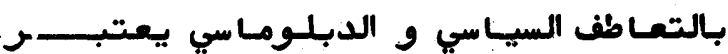



تقدم او تصعيد مع مورد الايـام طــــوال

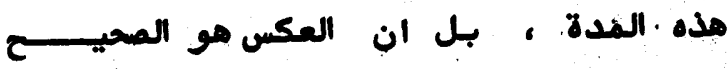

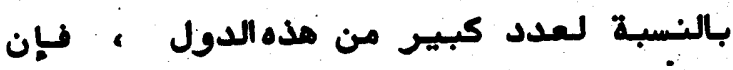

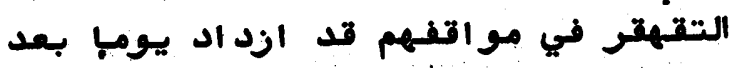

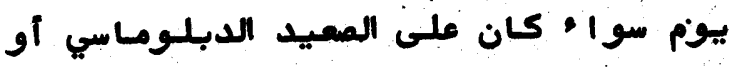
ملى المبستوى المحلبي فيمسا يتعلتق بـإرسبـال

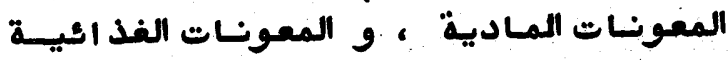

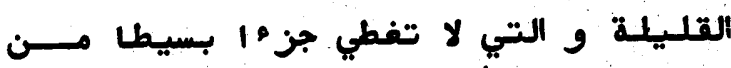

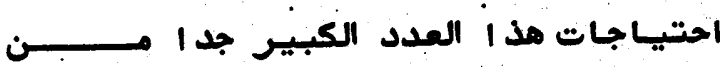
المهاجرين الموجودين في بـاكستـان واير ان

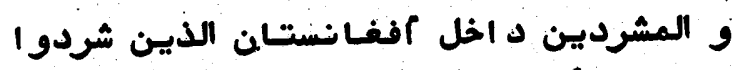
من منسزلهم و هم يعيشون بلا شيء د داخل

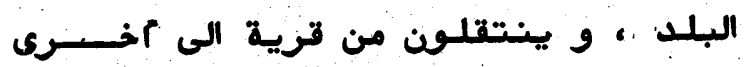

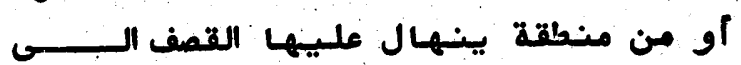

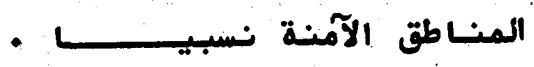

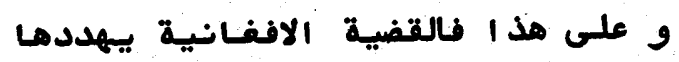

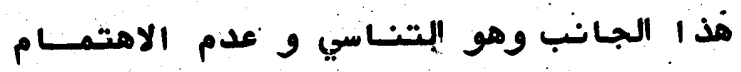

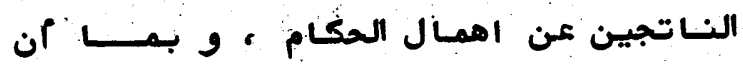

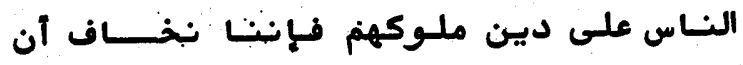

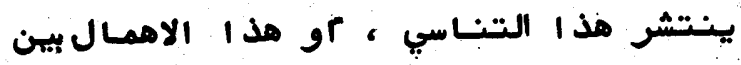

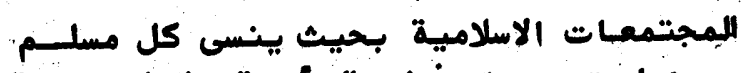

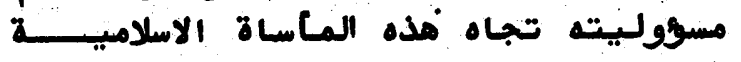

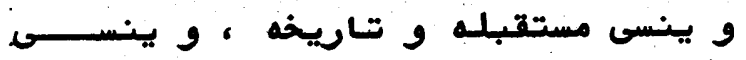

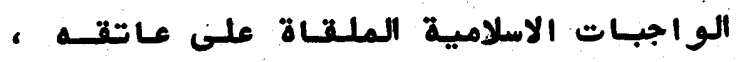

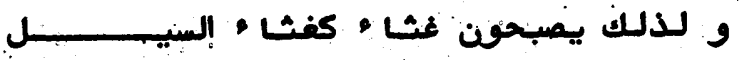
و زبدا على وجه المـا : ، كمـ اخبرالرسول

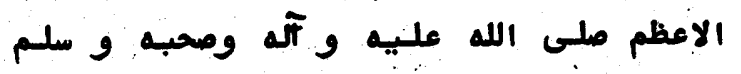
قبل خمسة عشر قرنـا. r بـ موقف الهيكـات و الجمعيـات الاسلامية بـمـا

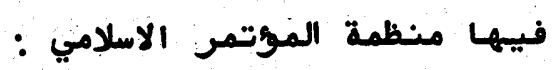
ان المتتبع لـقضية أفغانستـان والعـارف لجوانبها المختلفة يجد أن الفتور قدسياد

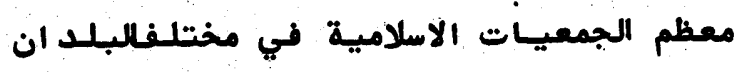

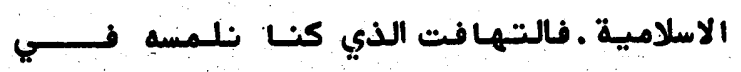

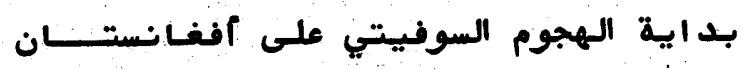

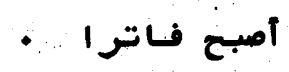

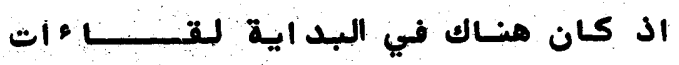

بل كان علـيهم أن يتبعو ال هذه المشياعسـو

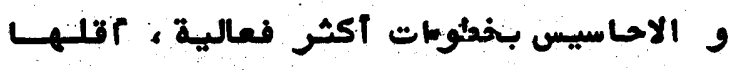

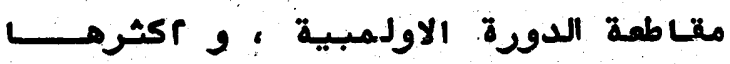

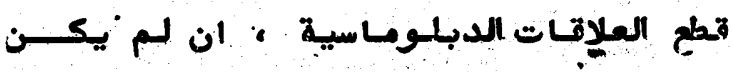
مع موسكو فعلف الاقلا قطعهـ مع الحكومسة

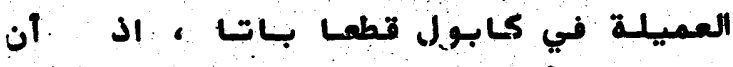

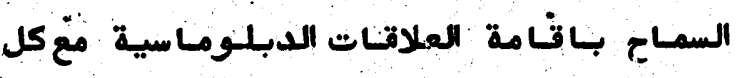
جمهورية من جمهوريسات الاتحاد السوفيتهي و هذ الأن الحكومة الاففـانية الفعليهة وهي التي تعيش تحنت رعايهة و حماية اكثر مسن مين

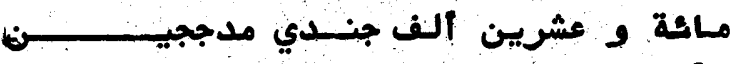

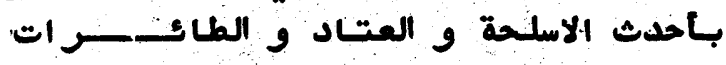

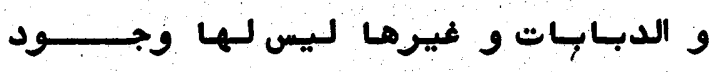

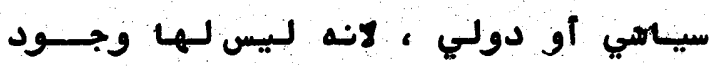

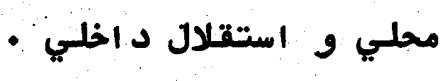

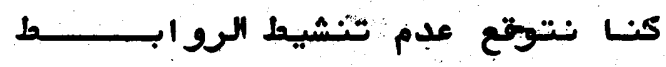

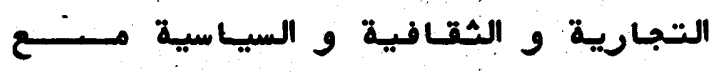

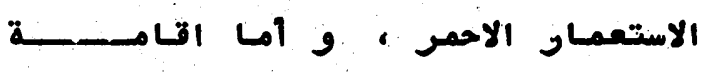

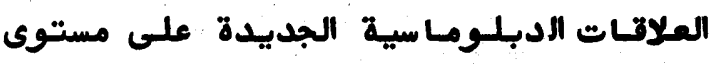

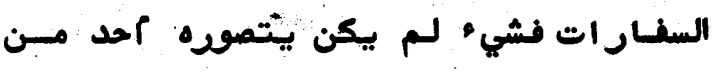
المسلمين أبدات فئري

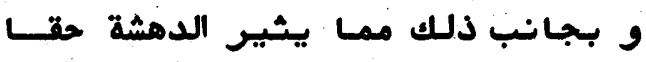

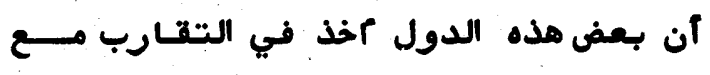

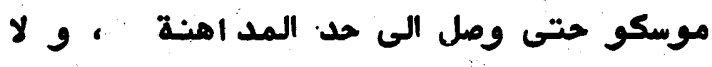

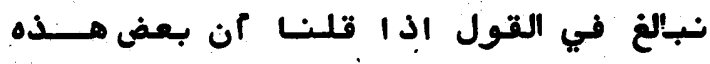

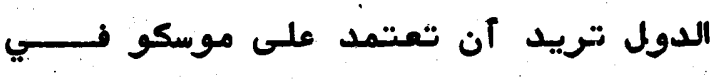

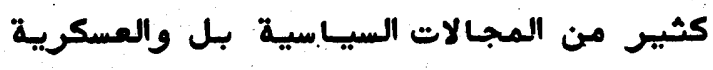

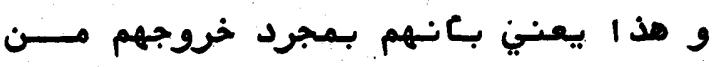
قاعة الامم المتحدة بو قاعة الاجتمـاعات

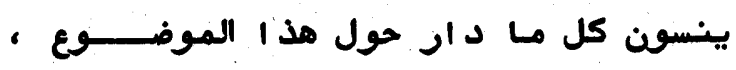

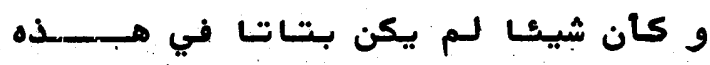

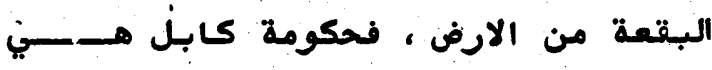

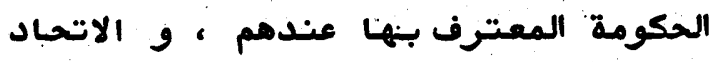

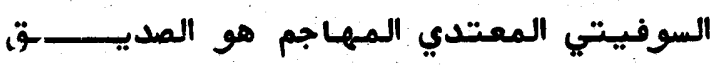

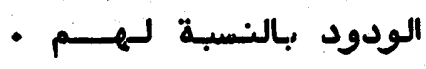

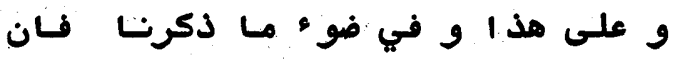

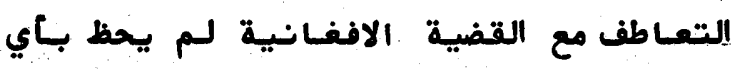


بمفة عـامة ، و المحيط الهندي كمـا هـــــو

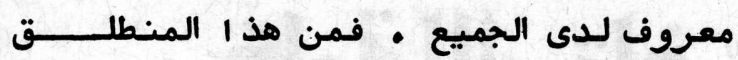

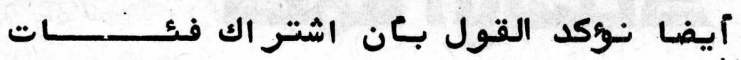
مختلففة منالبلد ان الاسلامية هو عبـارة عن

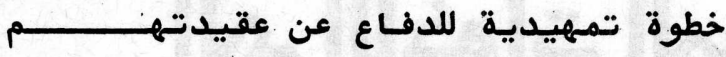
و أعر اضهم و كر امتتهم و أر اضيهم ، وأد أد أ

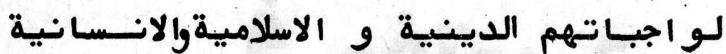

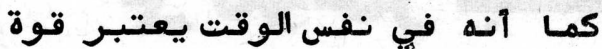

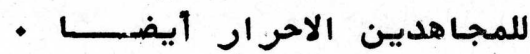

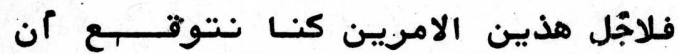
يدرك أخو انــا في جميع البلد اند الاسلامية

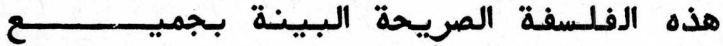

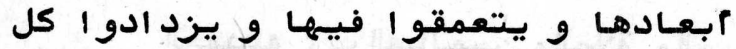

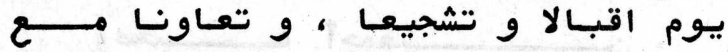
اخو انـهم في خنـادق القتــال دون أي فتـــور في عز اعممهم و دون آي شكوك في عقـاعدهم و بهذذا المنهج القويـم و الخط المستقيــــم و الفلسفة الو اضحة البينة سوف يكون النصر

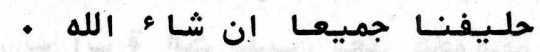

و تعالى على كل مسلم مهما كانـاعيا عن

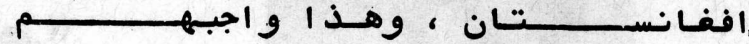

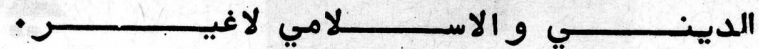

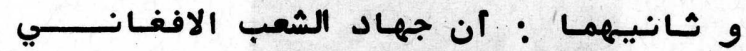

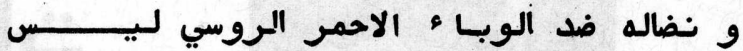

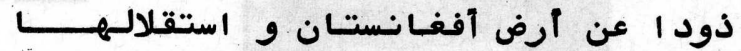
فقط و دفـاعـا عن كر امتهـا و عزة أهلـهــا

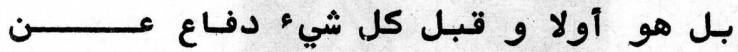

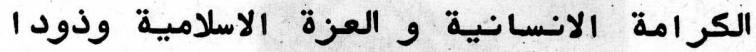

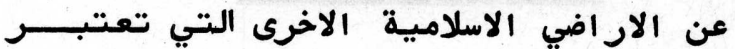

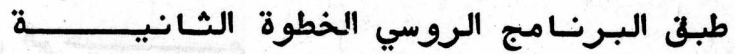

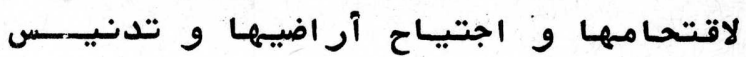

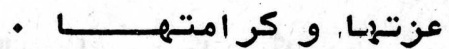

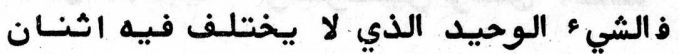

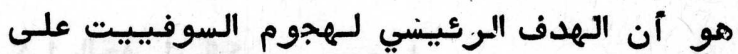
مففـانستـان و احتلالهيا بالشكل الذي نلـمسه

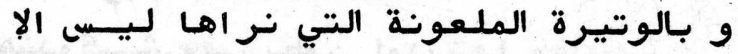

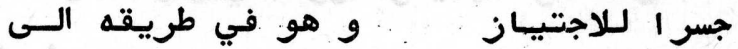

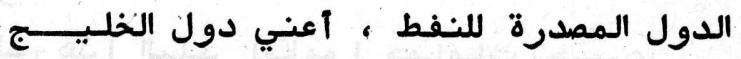

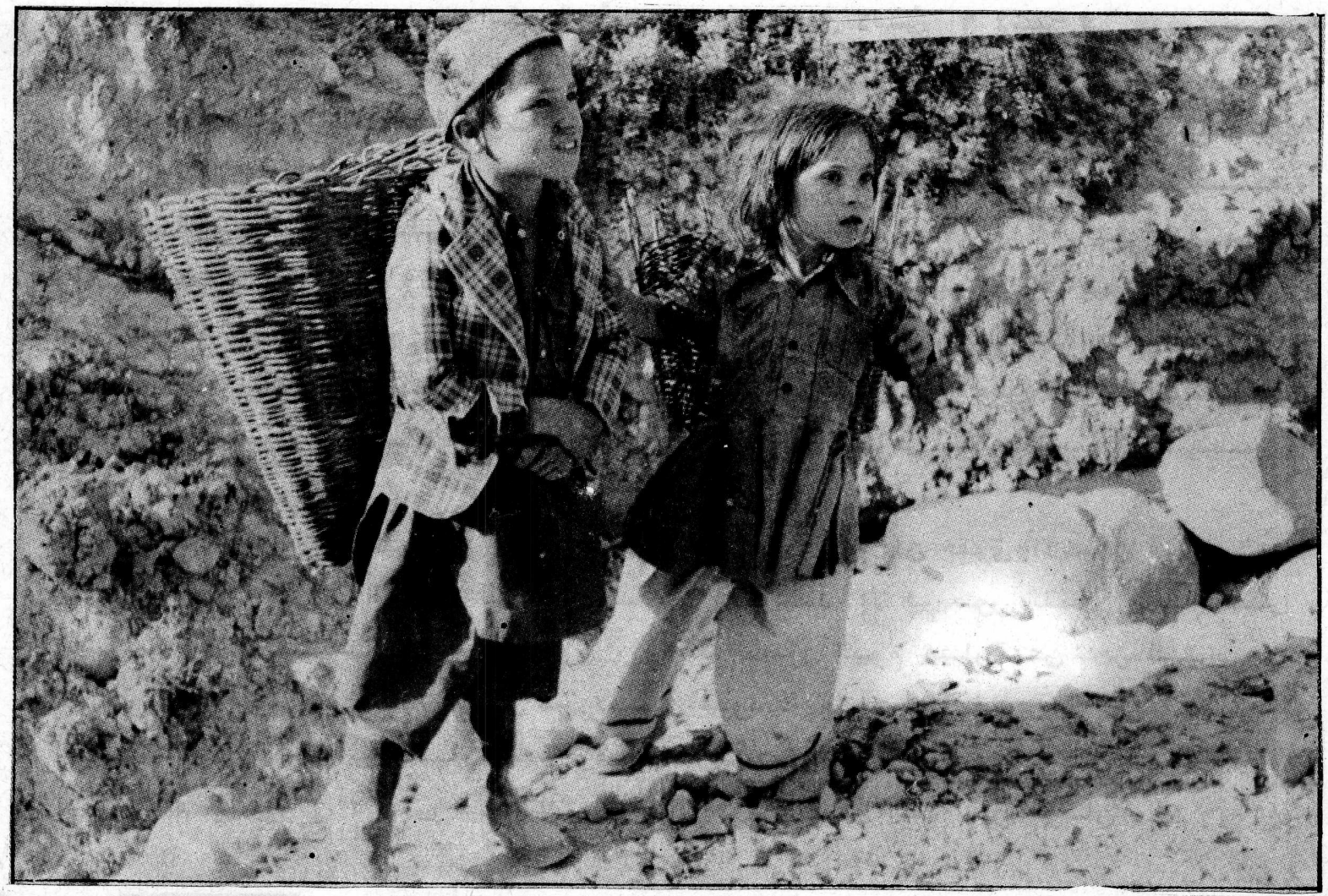

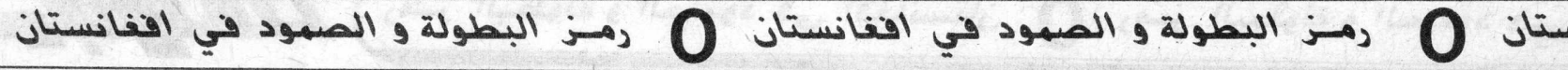




\section{كلمة الأستاذ "رياني"}

\section{الى الإخوات المسلمات}

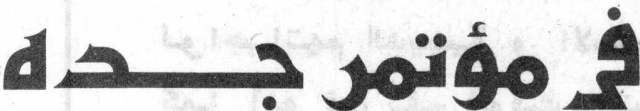

الحمدنله رب العـالــيـن والصلاة والســلام على افضل الانبـيـاء والمرسلـين وعلى آلــــه

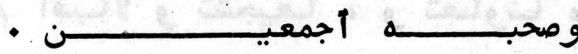

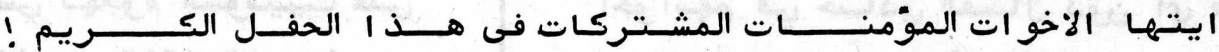

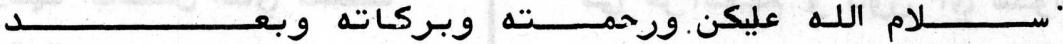

لايخفى علـيكن مـا يجرى على سفوح جبـال الهندوكـــثن وفي بطون اوديتتهـا وعلــــى

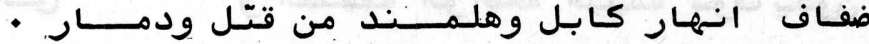

أن بر ابرة الكرملـين بعد هجومههم الغـادر على هذا البلـد اقـاموا حمـامـات تجــــرث

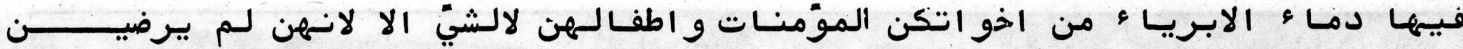

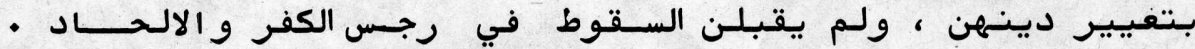

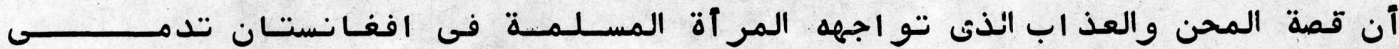

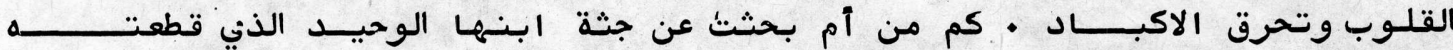

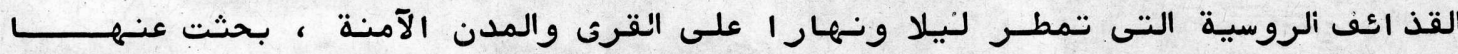

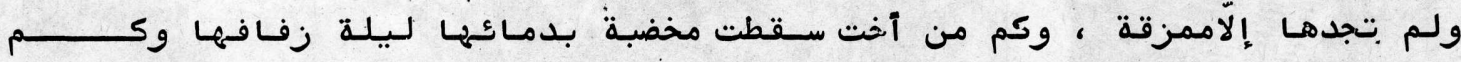

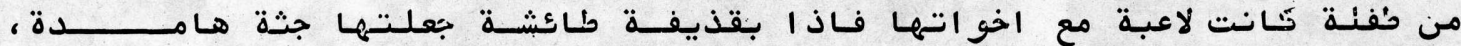

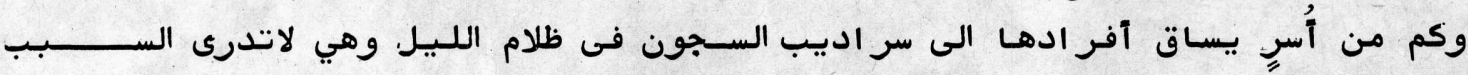

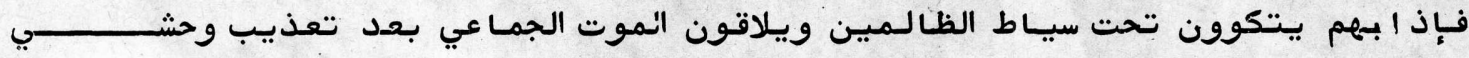

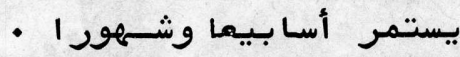
إن العالم اليوم يتحدث عن حقوق الانسـان وكر امته إلا أن حقوق الانسـان فى النذأم

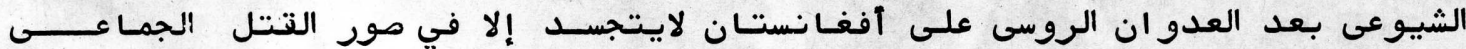

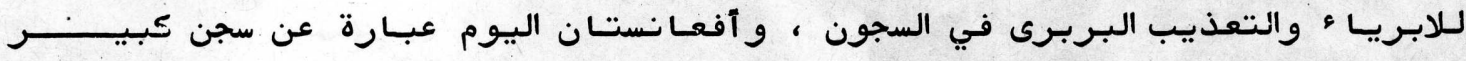

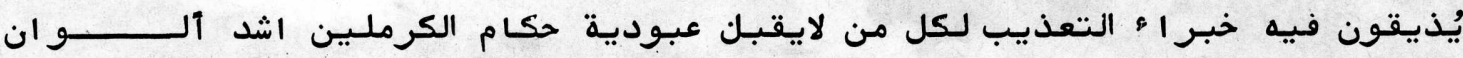

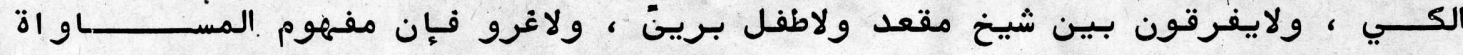

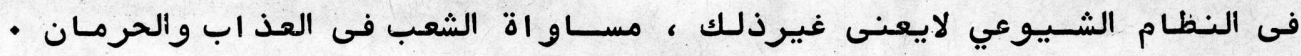

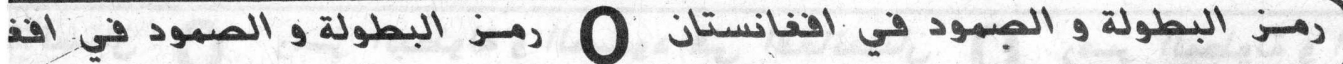




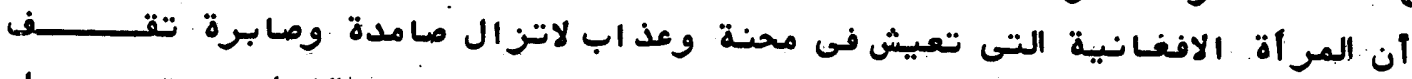

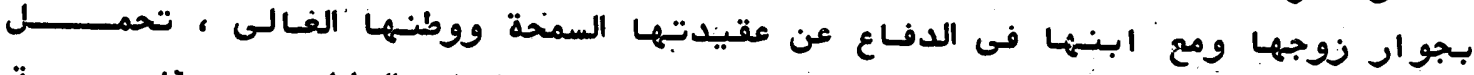

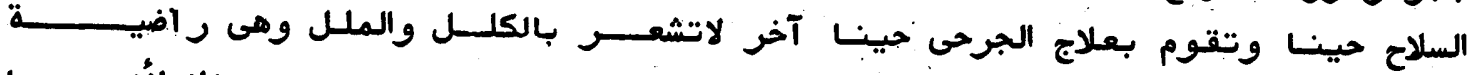

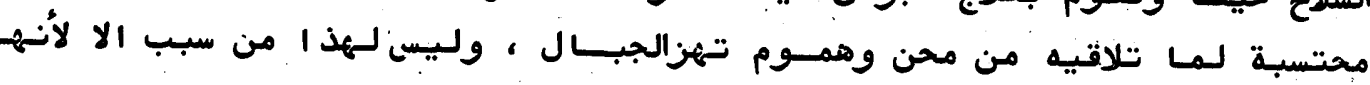

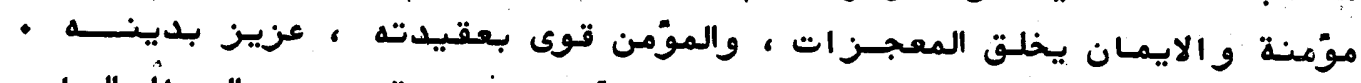

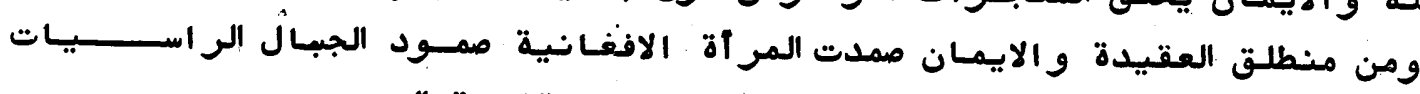

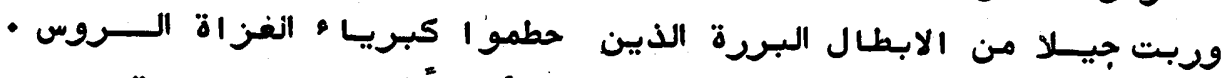

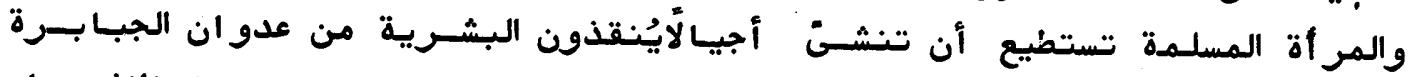

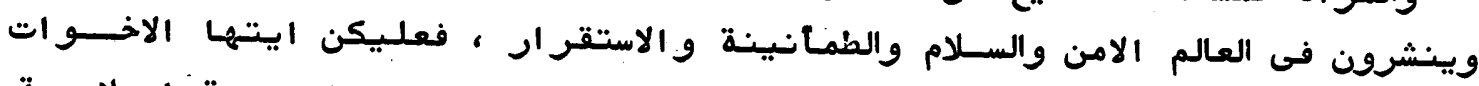

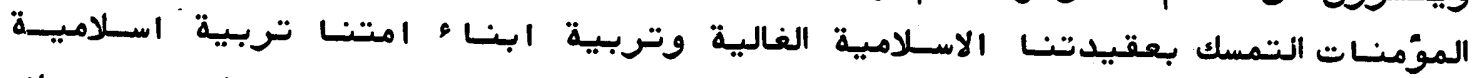

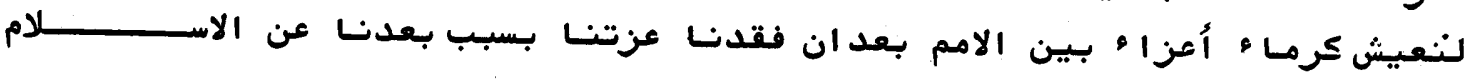

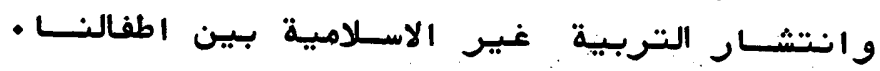

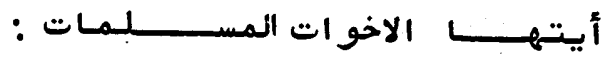

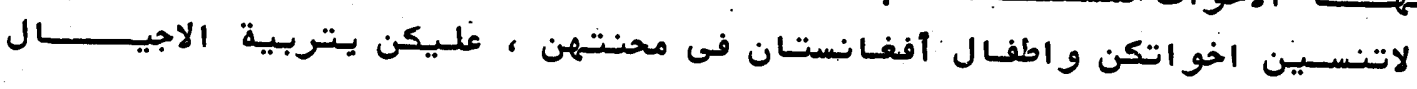

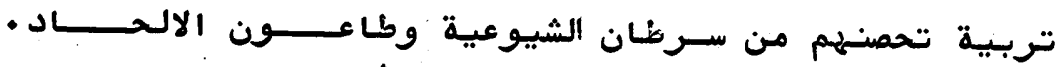

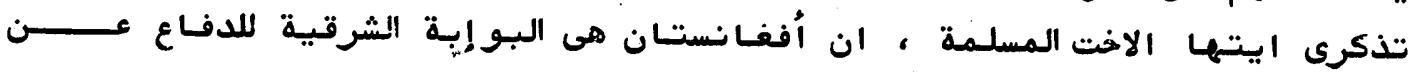

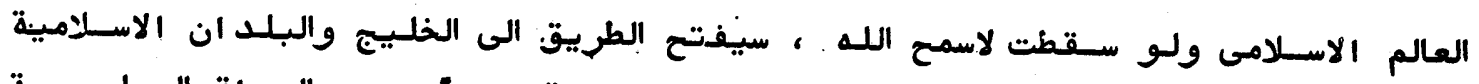

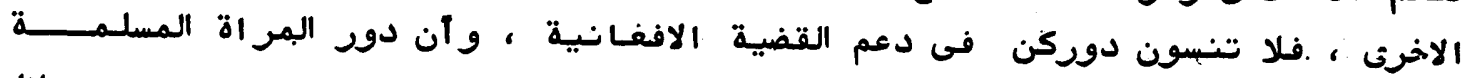

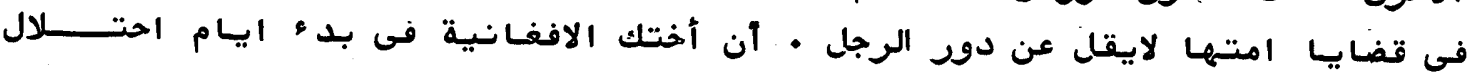

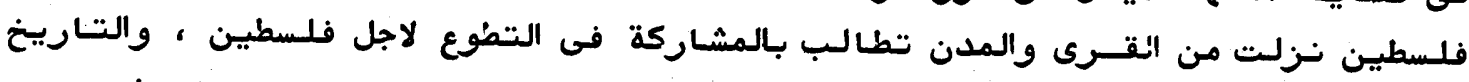

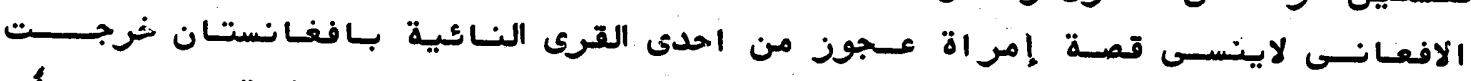

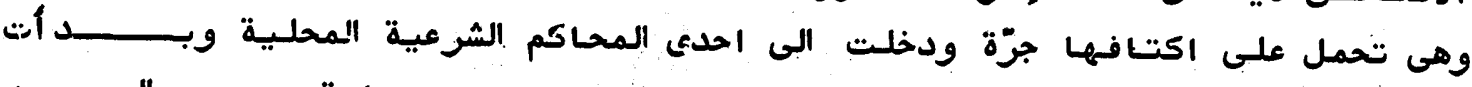

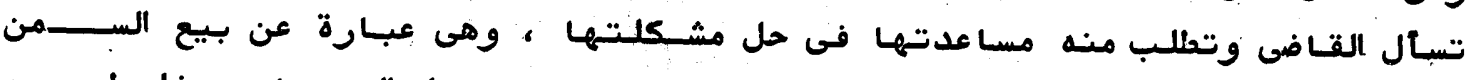

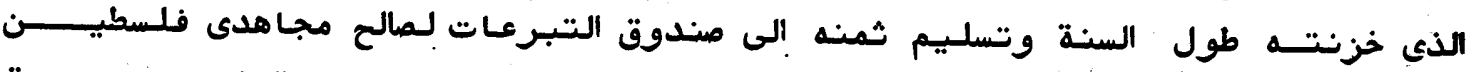

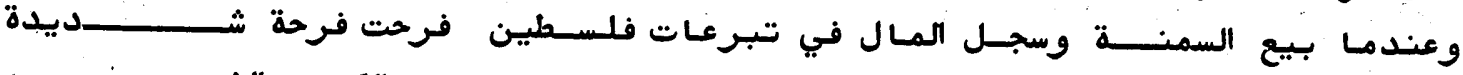

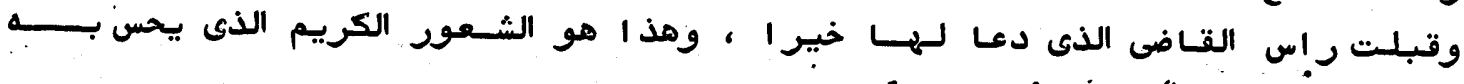

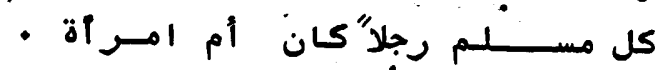

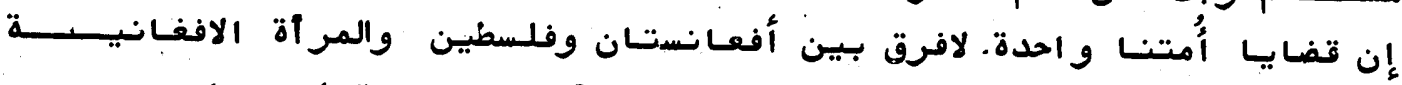

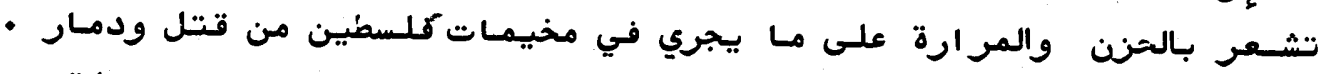

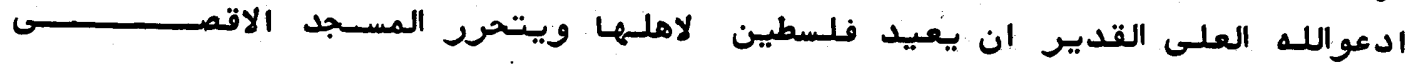

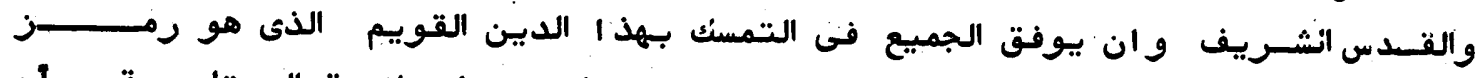

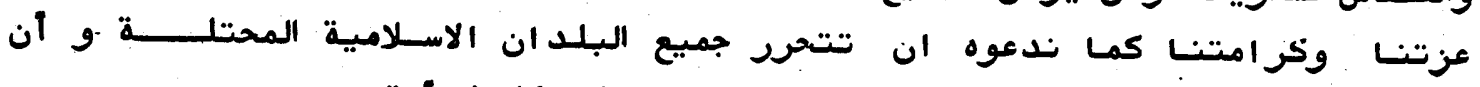

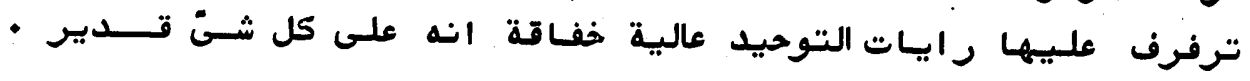




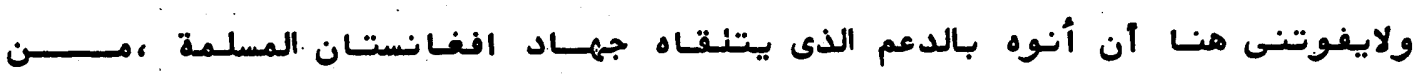

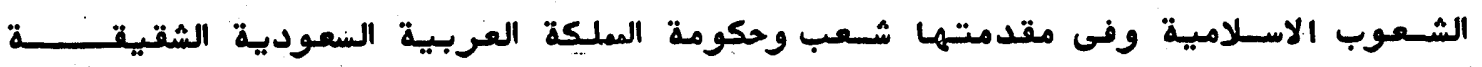

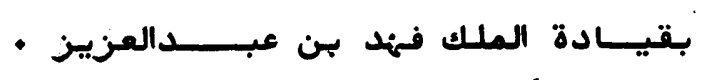

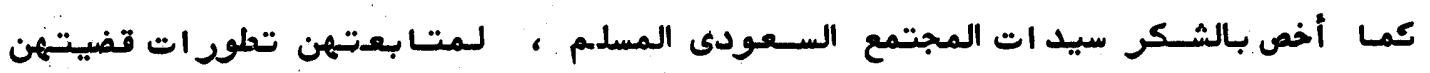

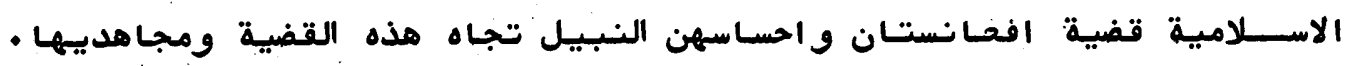

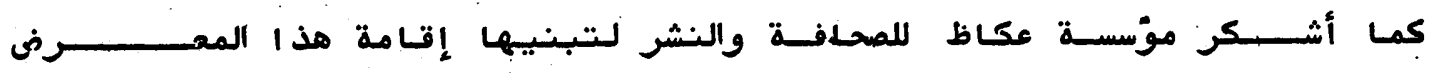

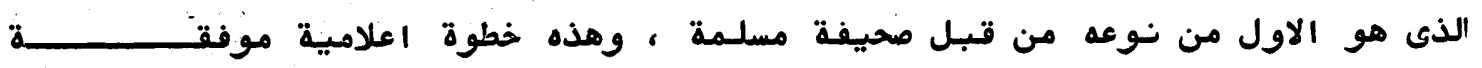

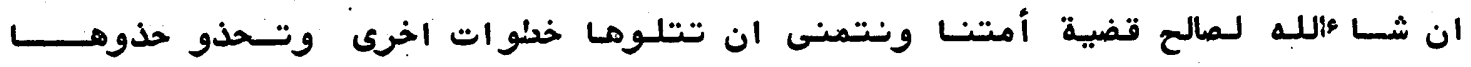

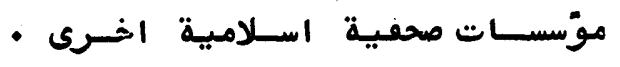

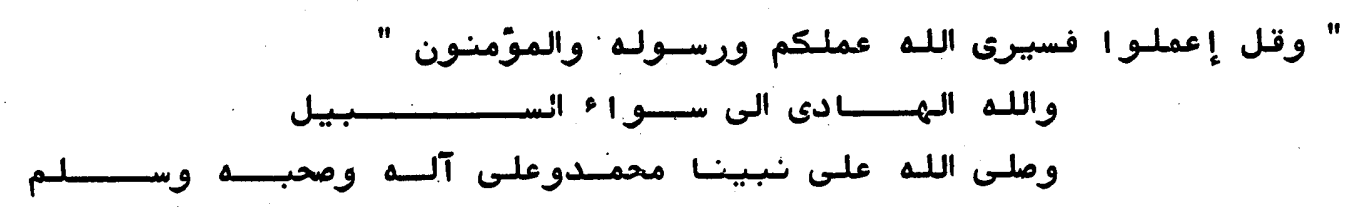
والسلام عليكم ورحمة الله وبركـات
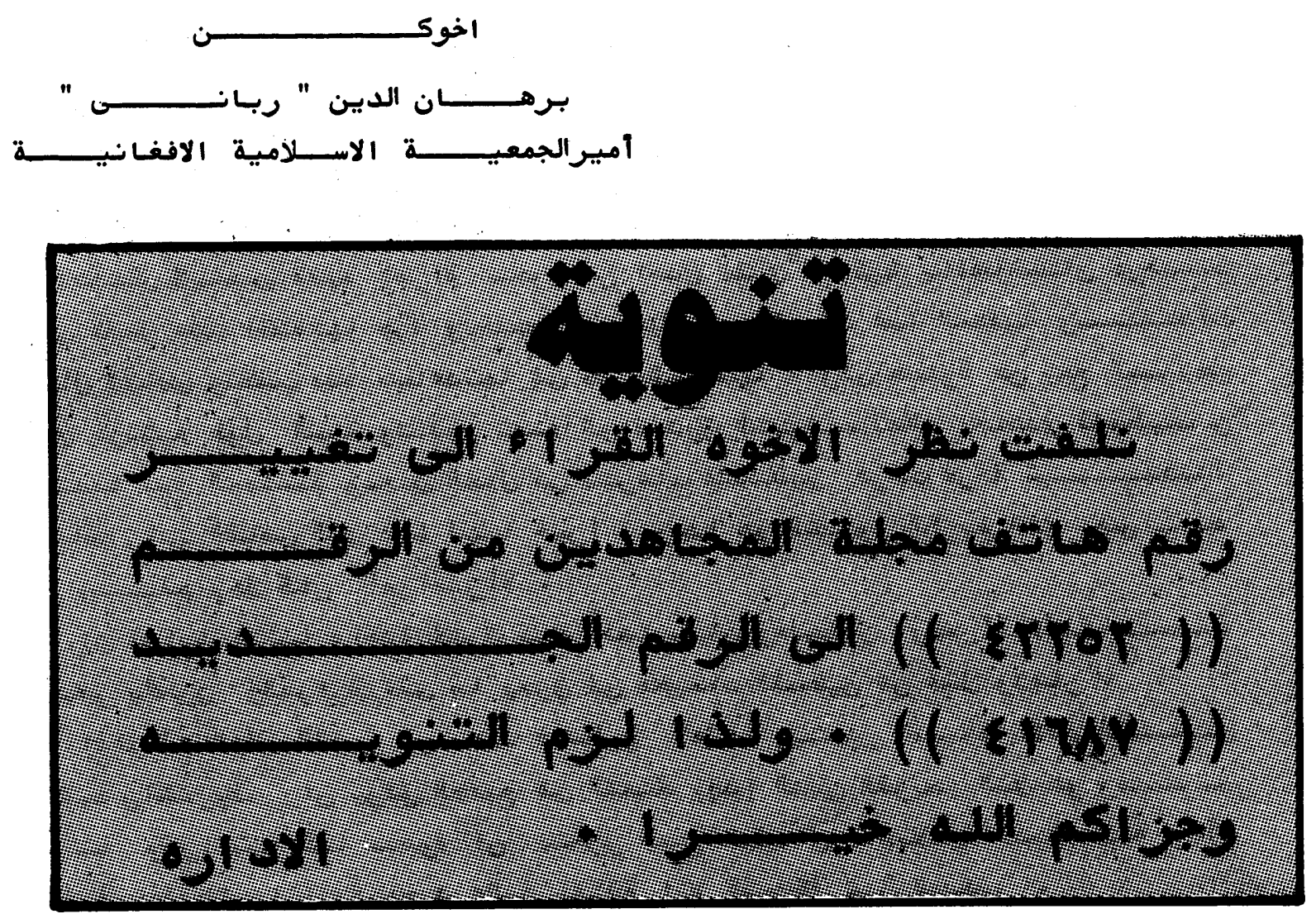

رمسز البطولة و الصمود في افغانستان O رمسز البمولة و الصمود في الفان

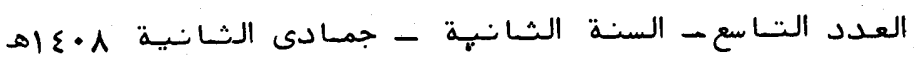


يكتمل فى السـابع والعشرين من شهر ديسمبر ( كانسـون الاول )

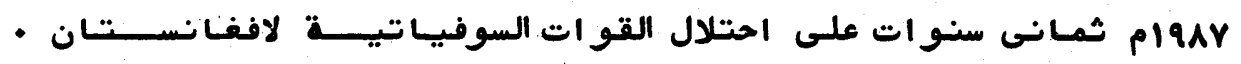

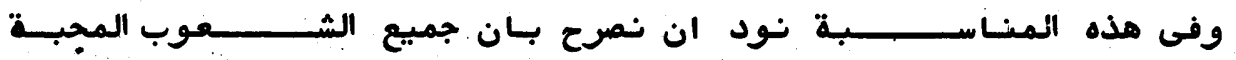

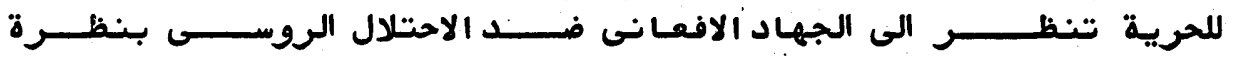

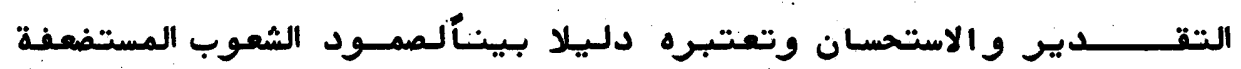

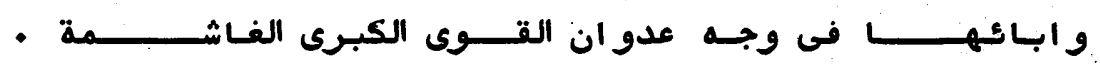

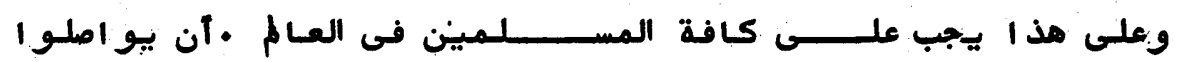

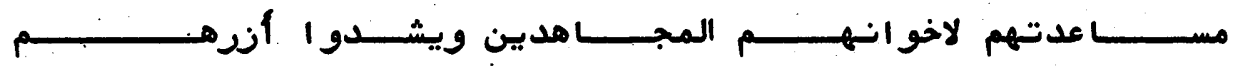

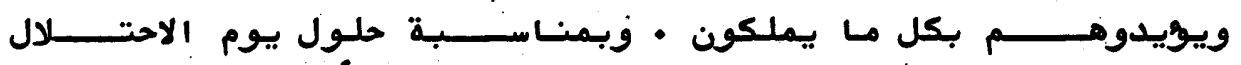

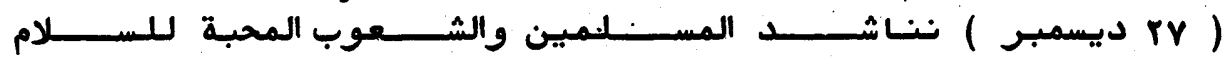

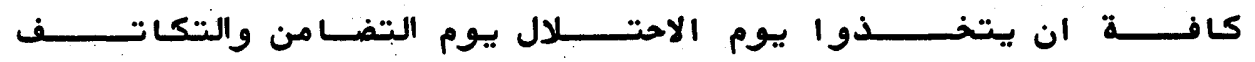

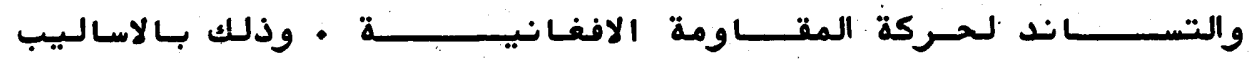

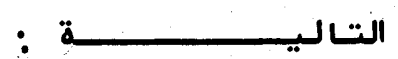

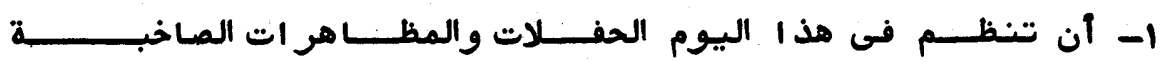

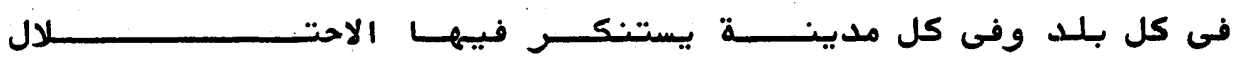

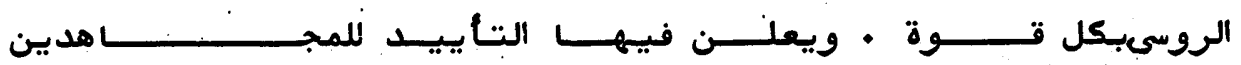

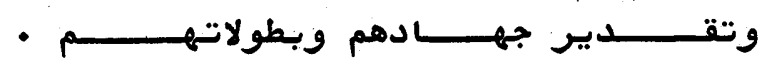

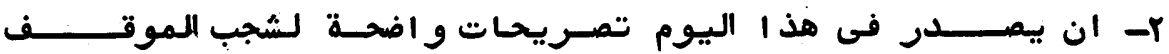

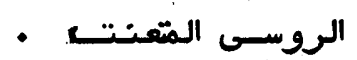

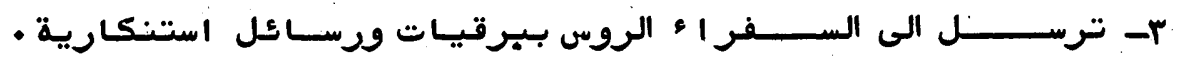

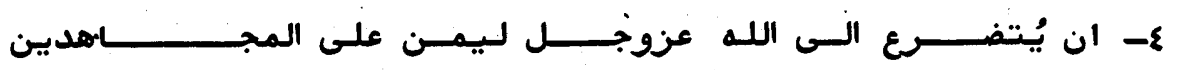

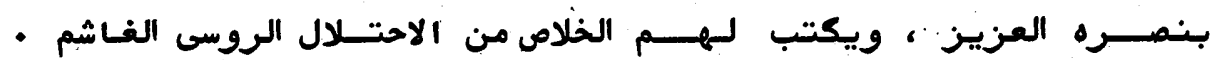




\section{احتجاجات عالمية فُ ذرمـ التحخل الروسي ف و افغانستان}

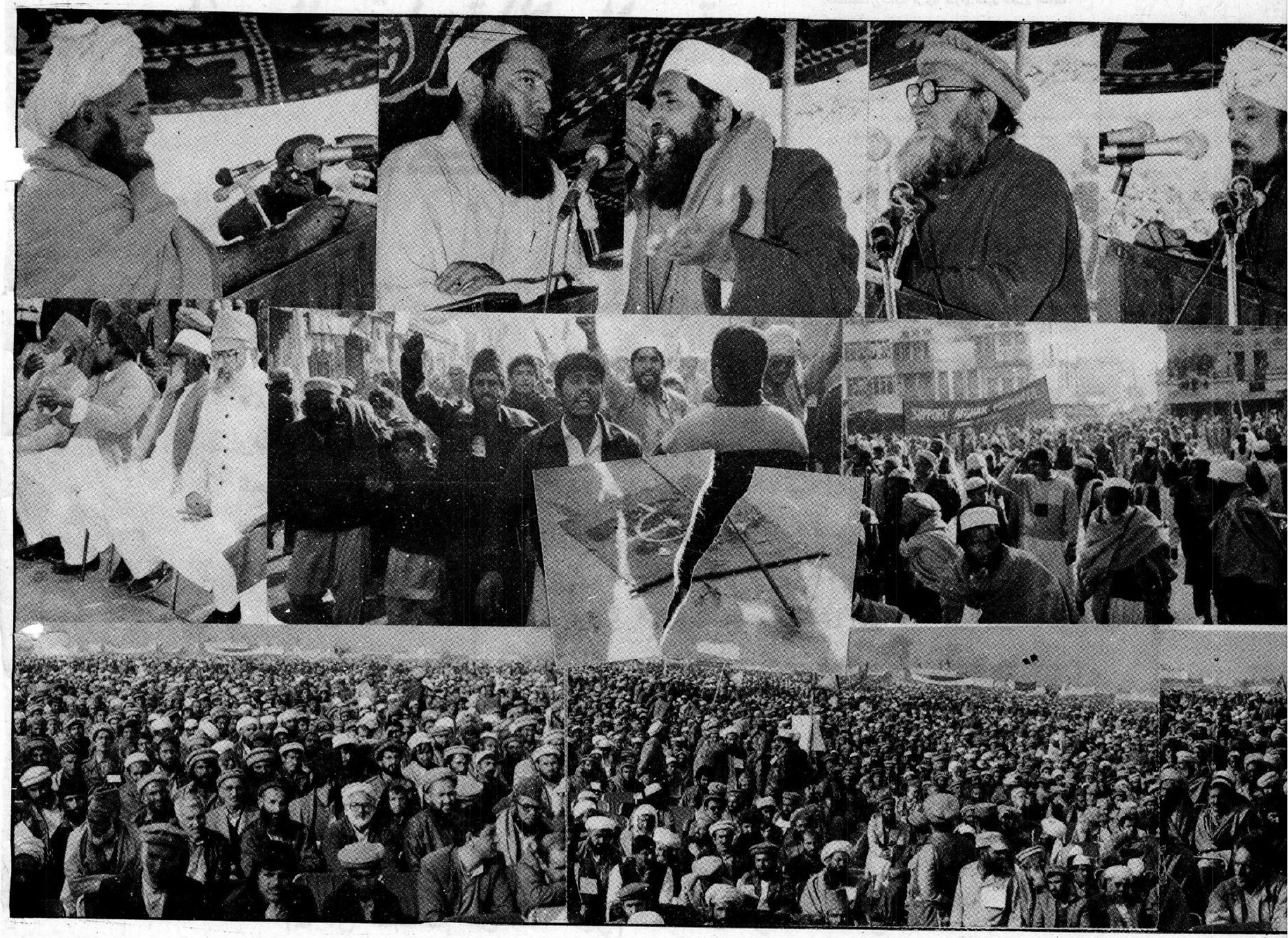

وتدميره للاخضر واليـابس ، ولـقد ، أعلبـــن

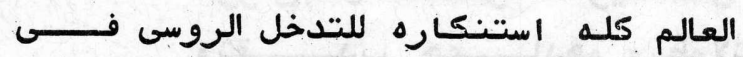

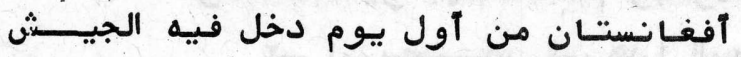

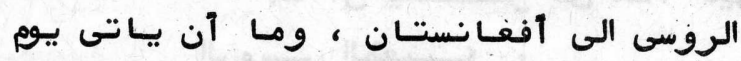
السابع والعشرين من ديسمبر الاويجددالعالم

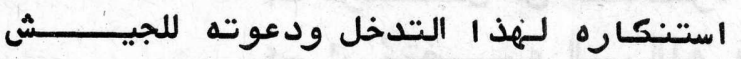

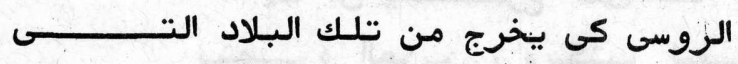
مصنت ثمـانى سنو ات على التدخل الروسـى

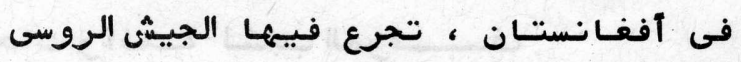

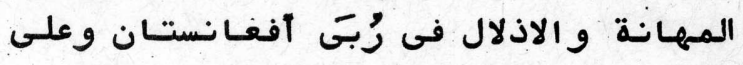

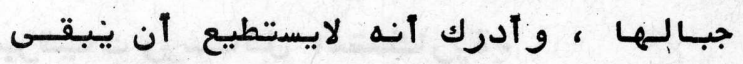

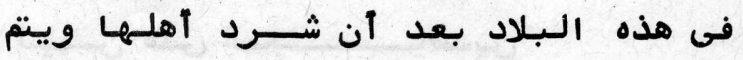
أطفالهـا بهجمـاته الظالمة على قرى الآهنية

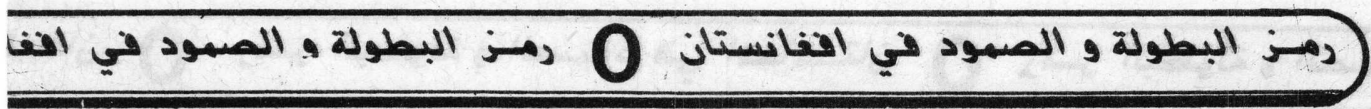

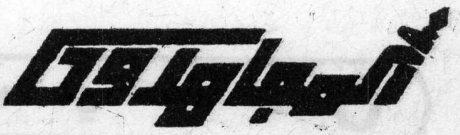




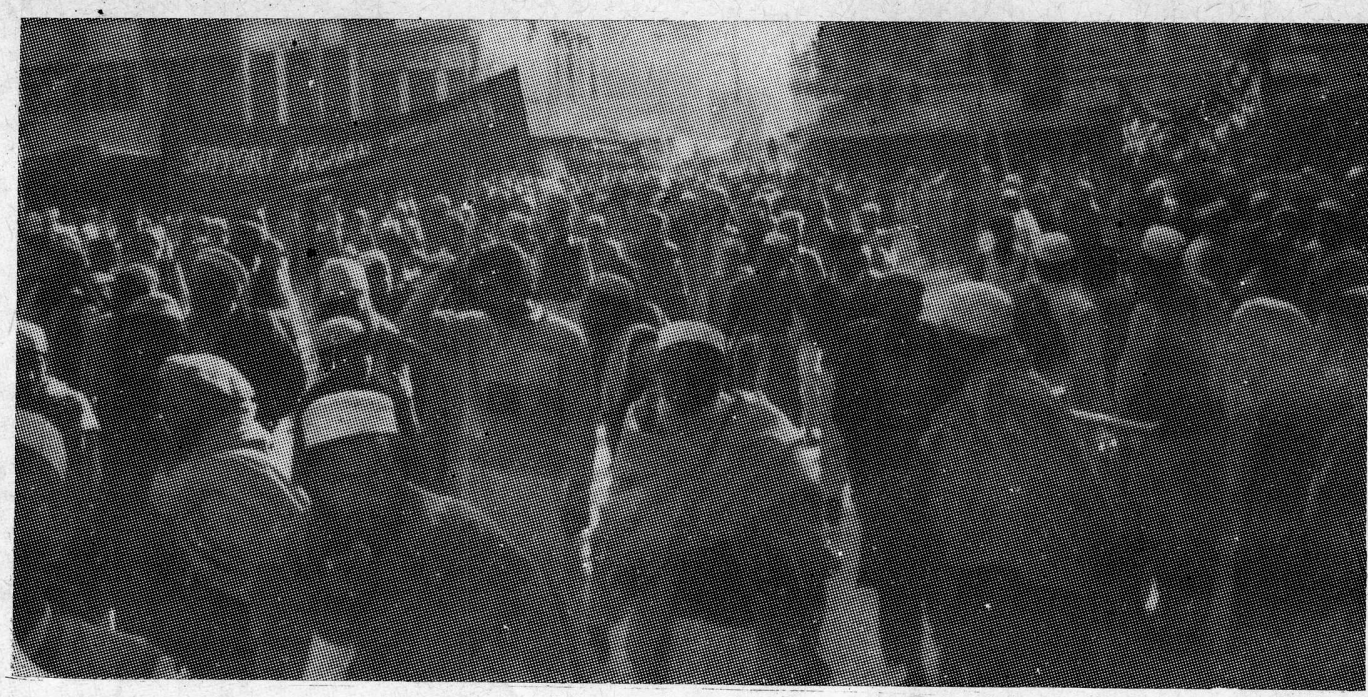

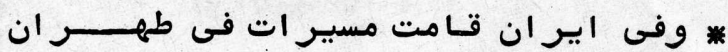

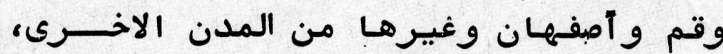
وفى أصفهـان هجم المتظاهرون على القــصلية

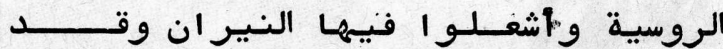

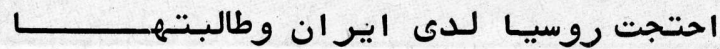

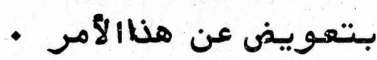

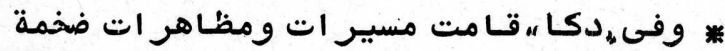

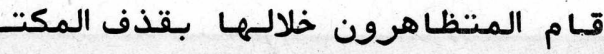

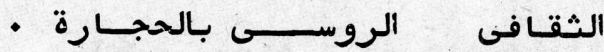

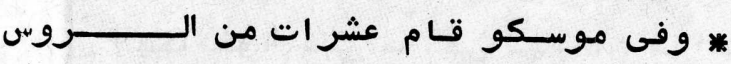

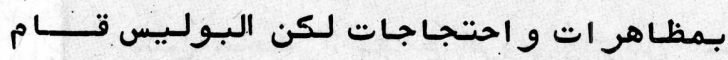

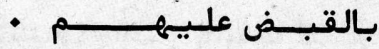
* وفى كـابل قـام عشر ات من الطلاب بمظاهرة

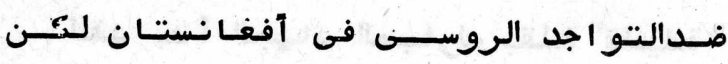

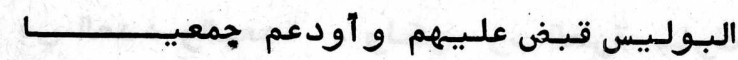
- الســـــــن

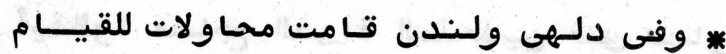
بمسـيـر ات ضد التدخل الروسى في ولى اففـانستان

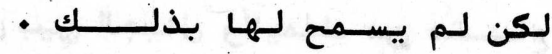

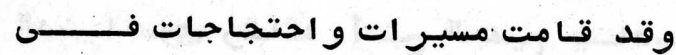

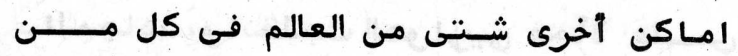

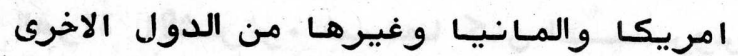

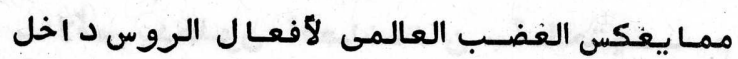
آففان
اغتصبهـا وشرد أهلهـا . .. وقد تمتُلت هـذه

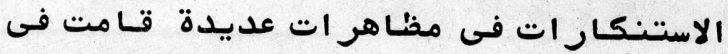

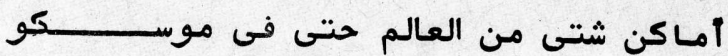
وكابيول :

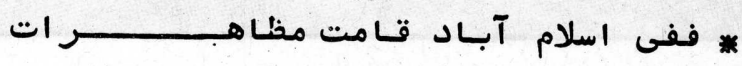

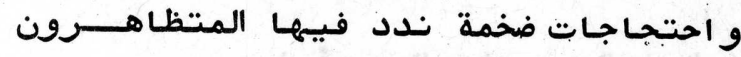

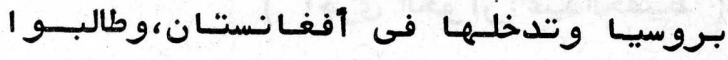

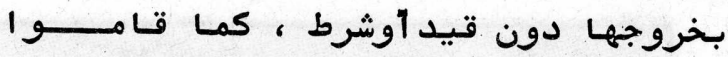

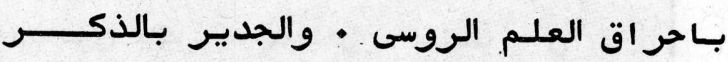

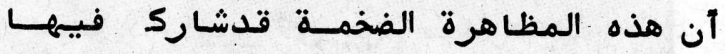
كثيرمن المسـلـمين من شتى الجاليـاتهوكـانت

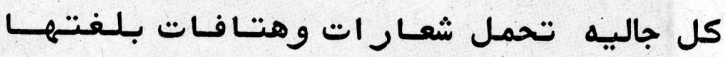
وفى نـهاية المسيرة قـام ممثلـو المجاهدين

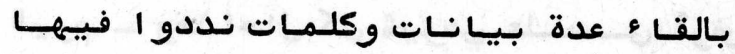

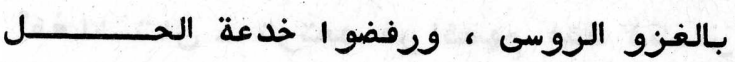

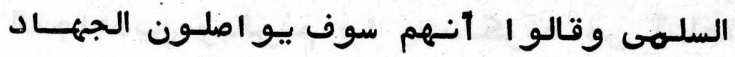

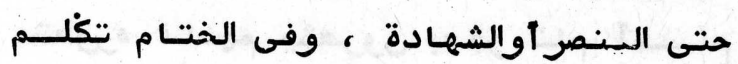

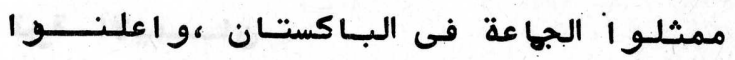

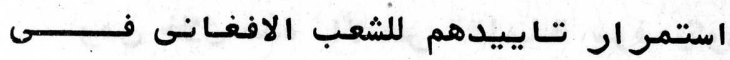

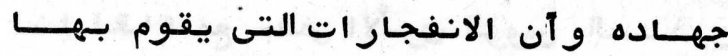

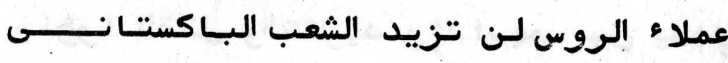

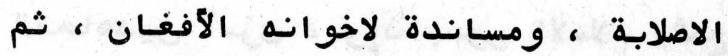
اختـتمت المسيرة بالدعـاءوالنصر - الاففــــــن

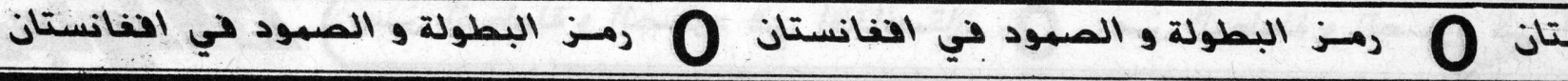


من العباد ات • أما الآن فهو يدرس كتــاب

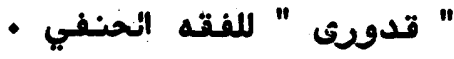

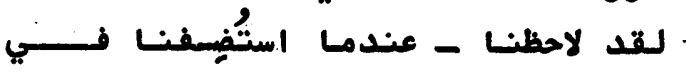

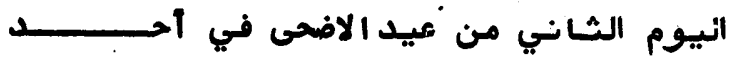
معسكر ات المجـاهديـن - آن الأسرى لايختلفون عن بإخو انهم الاففـان إلا من ناحية الشــــل

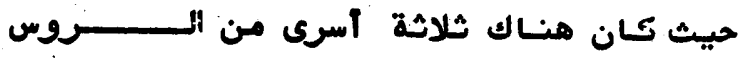
اعلـوا إسلامههم وصاروا يعملسون جنبا إلى جنب مع المجاهدين ويتناولمن معهم الطمام

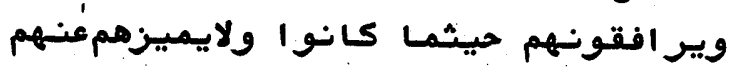
- سـوى الاعين الرزقـا م والشعر

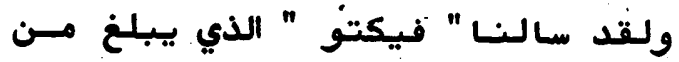

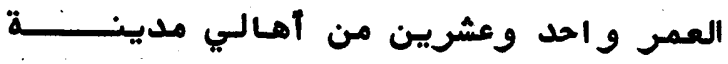

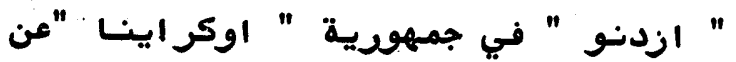
بد ايـة التحافه بالحزب الشيوعي فقـال: "كان ذلك لـما بلـغت السابعة من عمري"و أفاف :

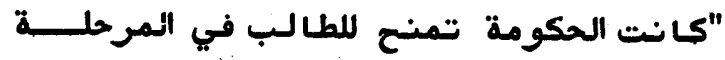
الاولى - عندمـا ينفم إلى الحزب - علامــــة حديدية تثم تفيروابعد عدة سنو ات إلىشريط

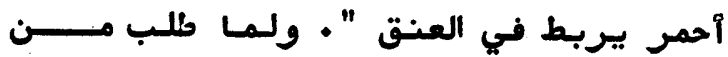

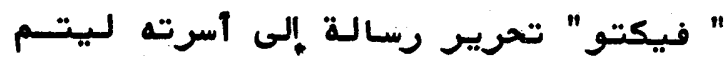

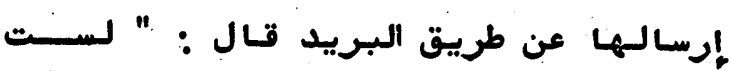
بحاجة إلى اربسال رسالـة "

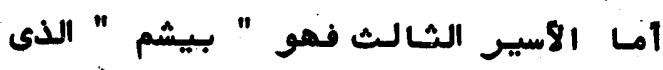
أمبح يلـقبه المجاهدون بعبداللهه • وقدوقع في الاسر قبل عدة سنوات في محسافنلــــــة "بروران" على " جبـلسلسراج " حينمسا كبـان مشضولا بجمع بعذ الخضر في إحدى المسز ارع قال : " بـيشم : كLت نمعي قنبلـة يدوية

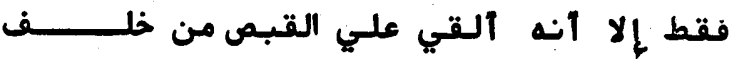

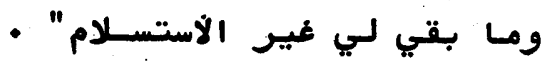
هذا الجندى الاسير يعمل هـإليـإلىجانب

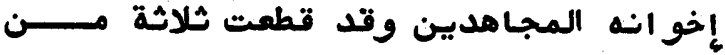
أهابعه اثر انفجار لغم على سيارتــهـه وهو من جمهورية ." تركمـانستان "ويتسدث بـانلفة الفـارسية بلـهجتمهيا التبي تعلـمها في
إخوانهم المجاهدين الاففسان وكثيرمنهـمنمني المادقين - يحاوللون التكفيرعماستق أن فعلوه قبل اسلامهم

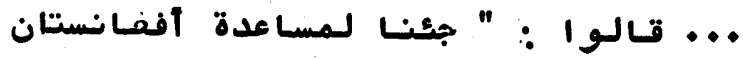

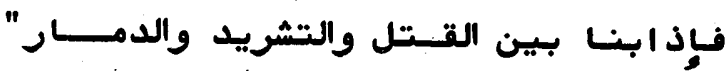
هذ ا مـا أشار السيه " سيركى " "الجندى الروسي

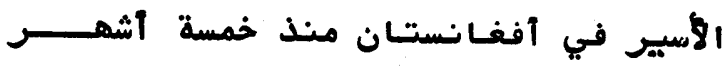

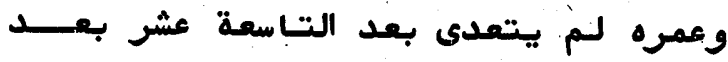
أن مار يعرف بعخل الكلمـات بـاللعة الرفـارسية شم اضانى : "كنت أبيع بنـزين السيارة في

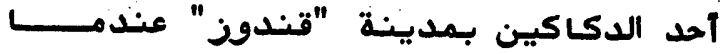

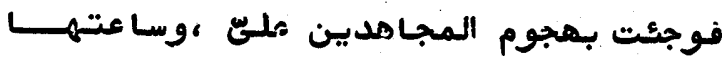
وقعت في الاسر و اخبر "سيركى" المجاتمدين بانه من أهالى

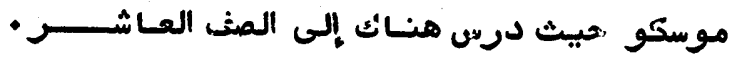

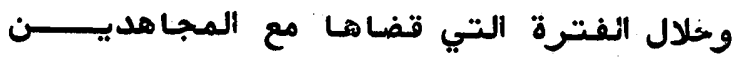

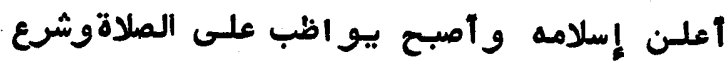

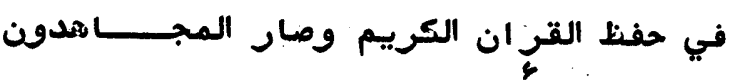
- يلـقبونه باكمد

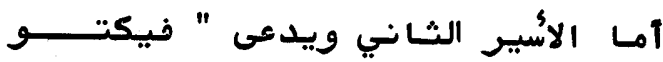

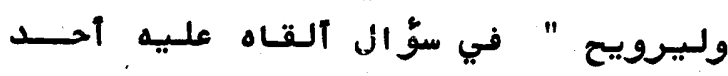
الاخوة : " ل لمـاذ ا ذخلـت القو اة الرونيســة

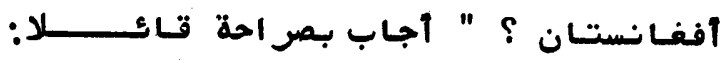

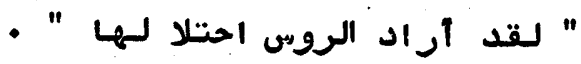

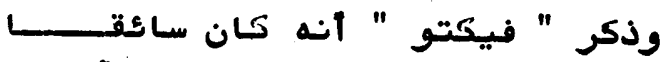
لاحدى سيبار ات " جيب " "ووتع في الأنســــ

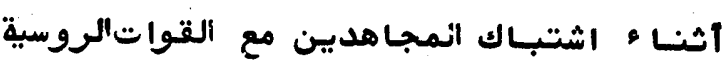
وبعد إعلان اسلامه أصبح " فيكتو " "يلـب

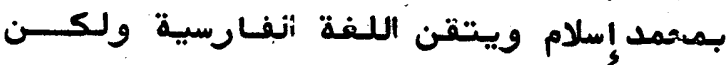

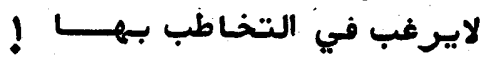

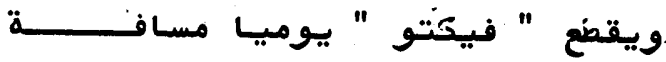
نيلـومترين لـتعلم القر آن الكريمر على أيدي

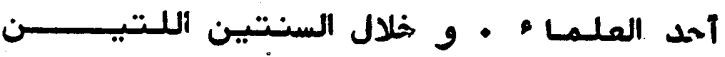

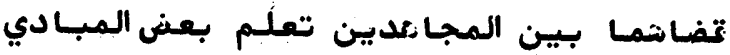
الاسلامية و اطلـع على ألحديد من الحتبابـاتم هذا اضافة إلى مو اطبـته على الاضُلاة وغيرها 


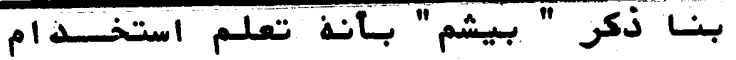

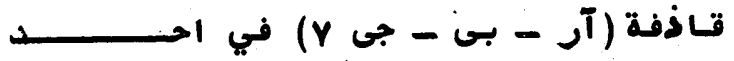

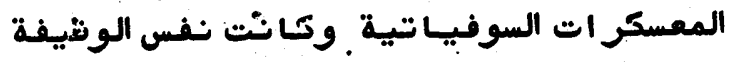

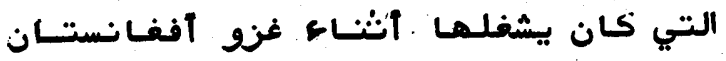

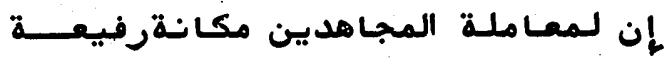

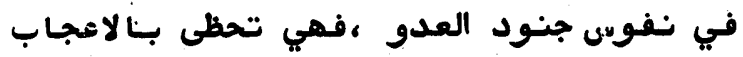

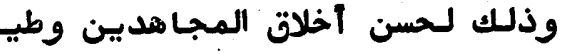

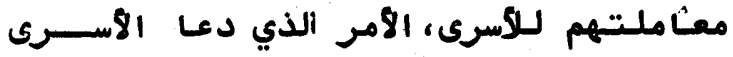

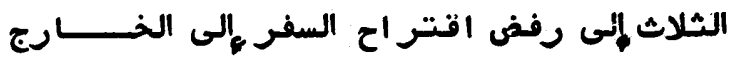

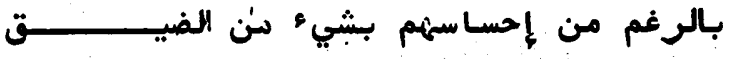

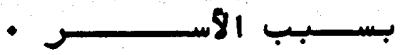

المنـاطق أعليـا من وادى بنجشير ولايمكـن

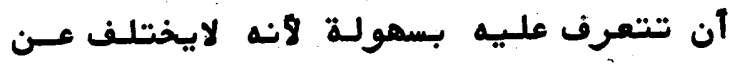

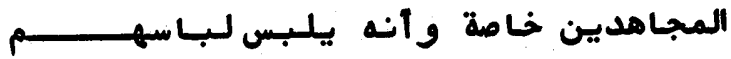

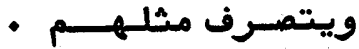
ولقد سئل "بيشم" غن كيفية مجئه إلى فئى

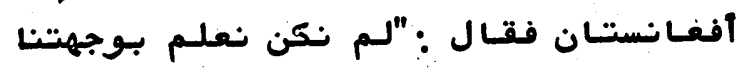

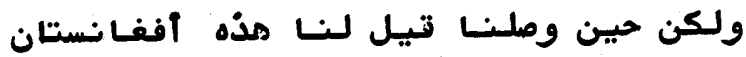

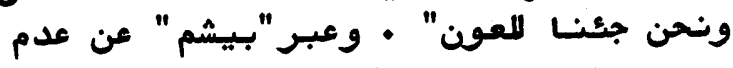

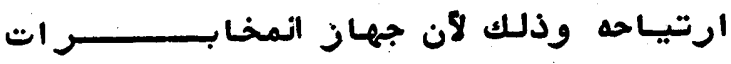

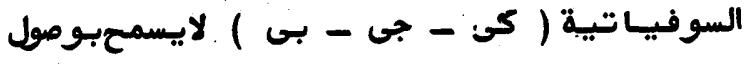

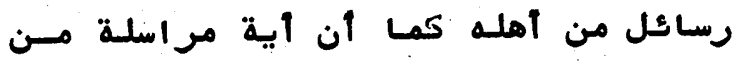

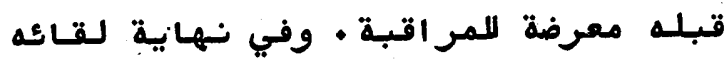

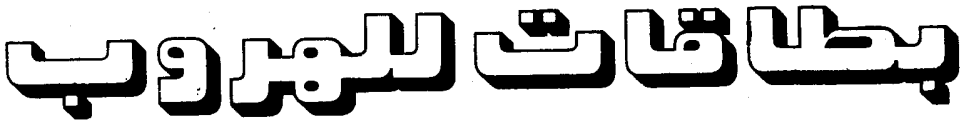

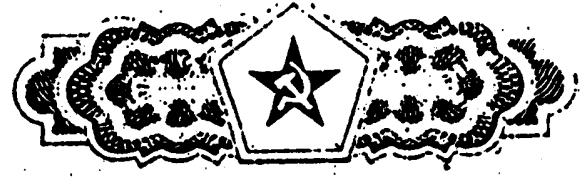

дOחYCK

НА ВНЕОЧЕРЕДНУЮ ЭВАКУАНИЮ

TOB

IPEДOCTABRAETCA ПPABO HA

ВНЕОЧЕРЕДНУЮ ЭВАКУАНИЬ ВОЗДУШНЫМ

И НАЗЕМНЫМ ТРАНСПОРТОМ С СОХРАНЕНИЕМ всеX льгот нА пОлученние жилья и пРОДУКТОВ ПитАнИЯ ПО ПРИБЫТИИО

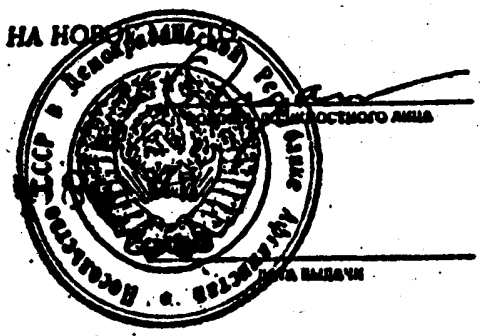

وقع فى أهدى المجامدهين نمودج لبطاتسات الهروب التى

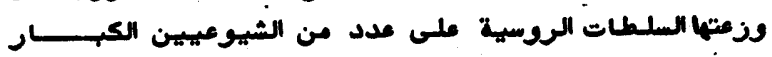

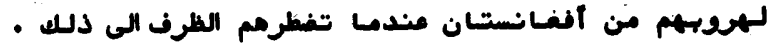

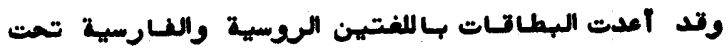

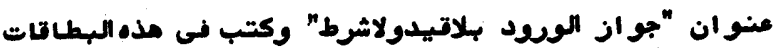

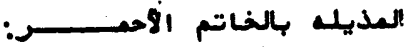

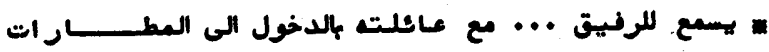

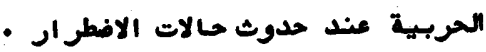

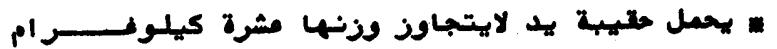

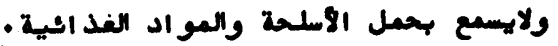

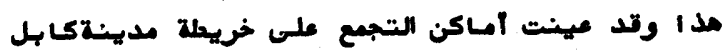

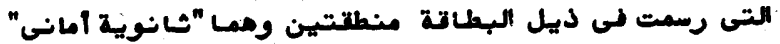

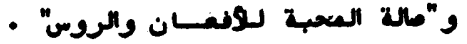

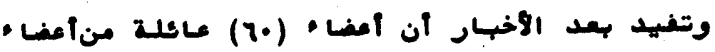

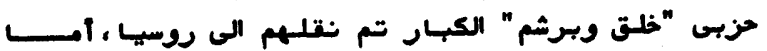

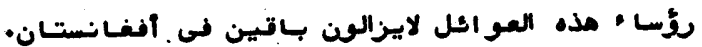

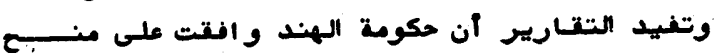

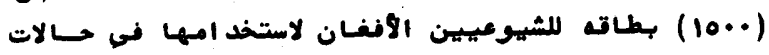
- الاضطر ار ل)

رمسزز البطولة و الصهود خي الفانستان O O رمسز البطولة و الصهود دي الغ 


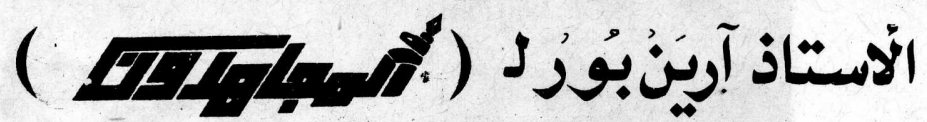
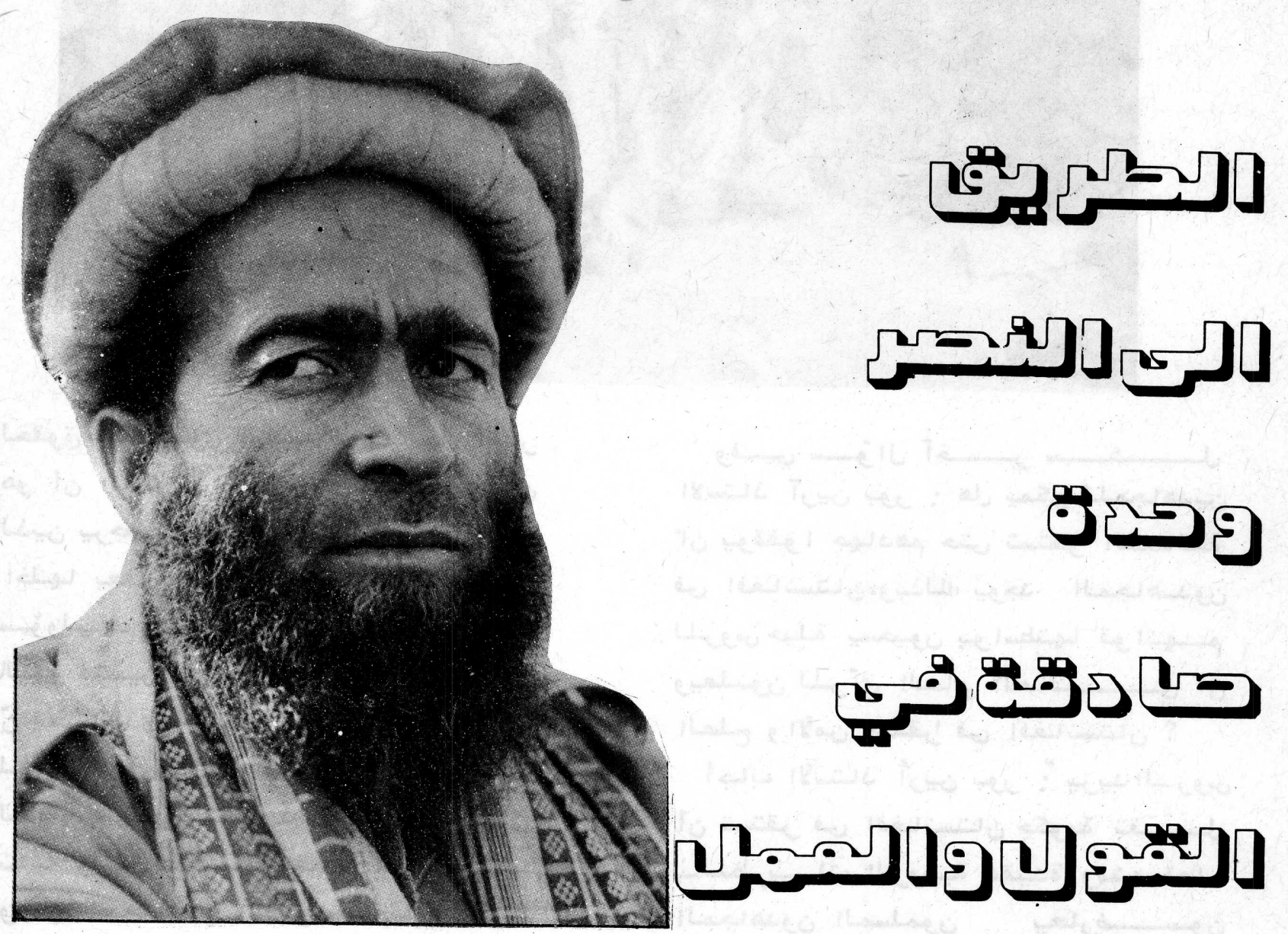

פכكتة

الاستتاذ ارين بور ضمن لقاعه بـالاخ حفيظ الله ولقد أبدى الاخ أرين بور رآيه بخصوص

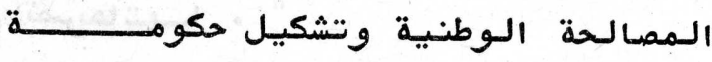

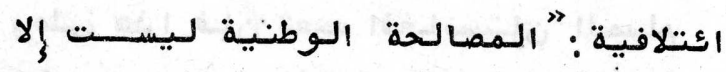

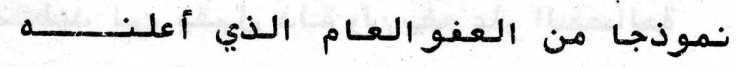

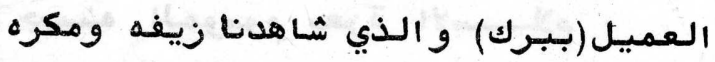

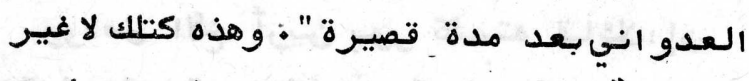

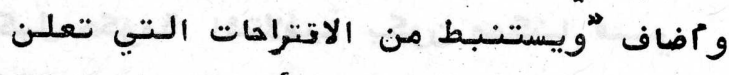

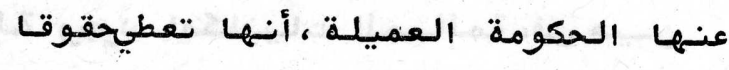

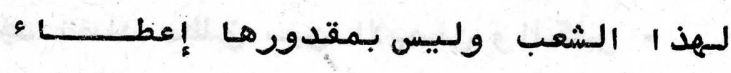

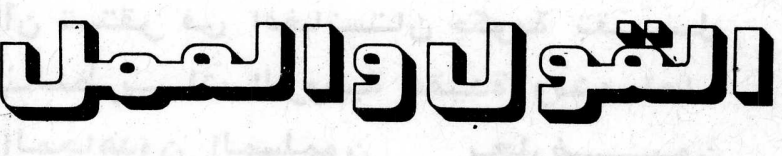

b פ

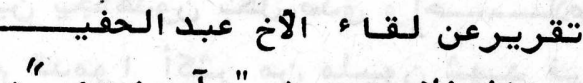

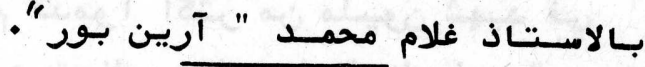

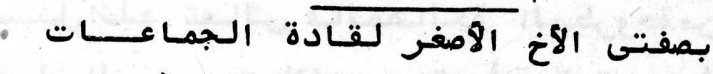

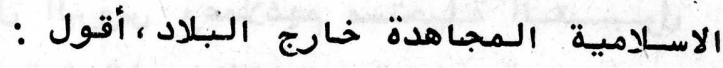

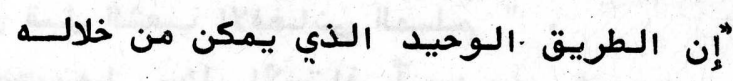

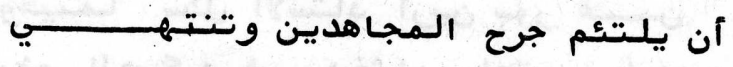

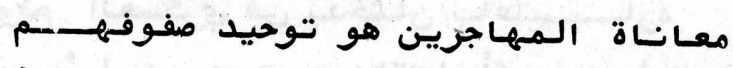

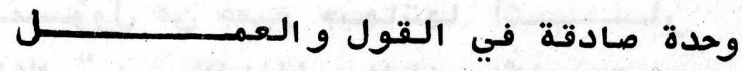

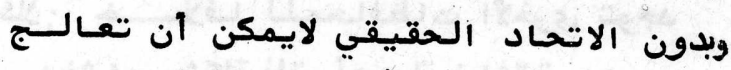

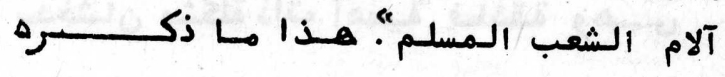

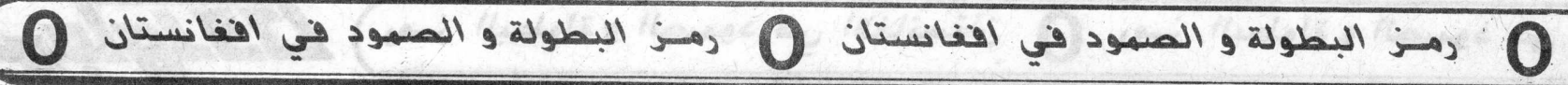




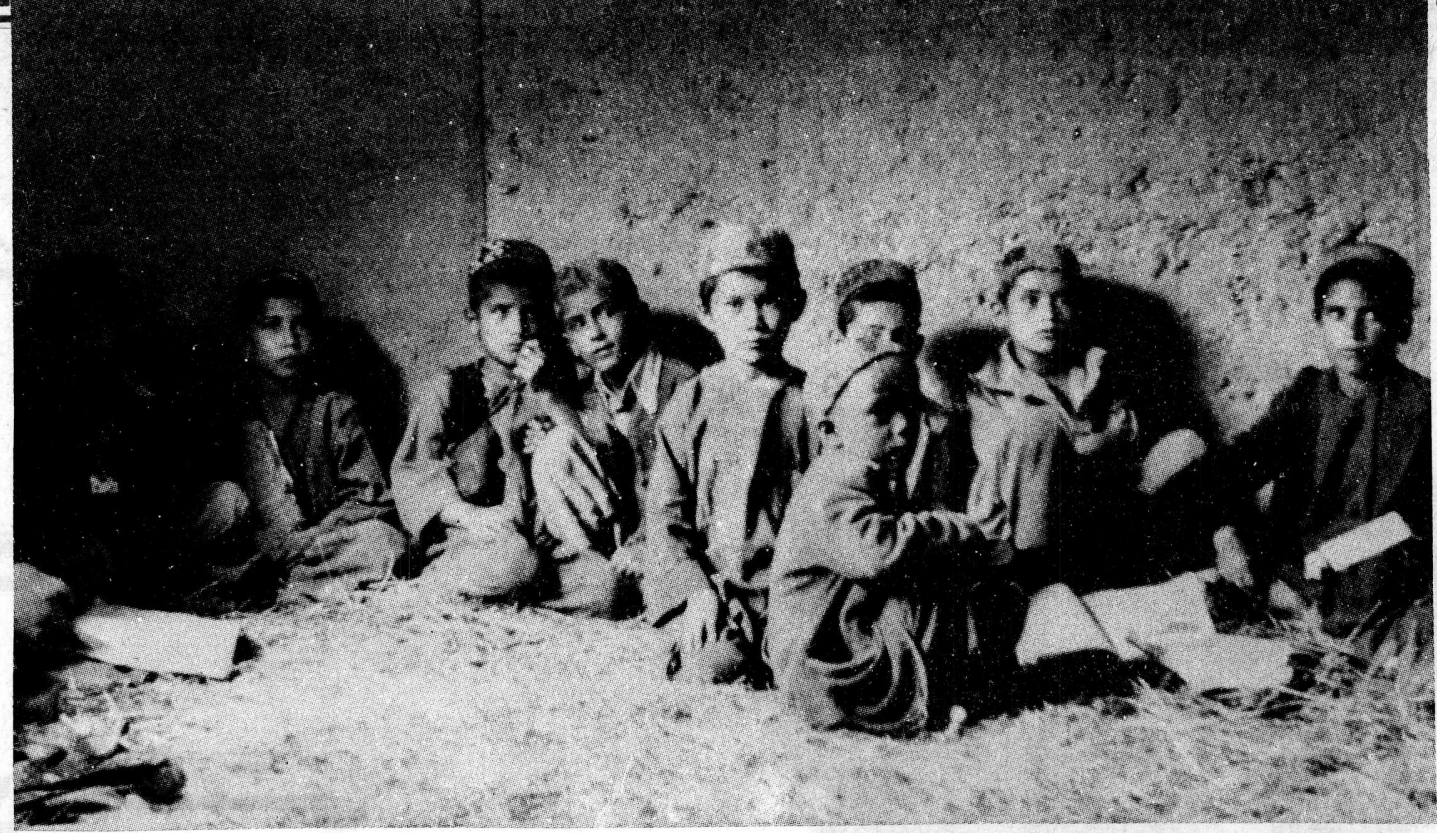

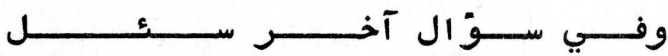

الاستـاذ آريبن بـور : هاى يمكن للسمجاهدين احن "ان بيوقفوا جهادهم حتى تستقر الـمصاللحة فى اففـانستـان،وبذللك، يوجد السمجا هـدون لـلروس حيلـة يسحبـون يسو اسطتهـا قو اتتهـــم

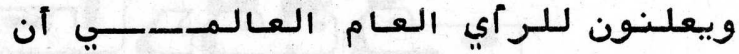
السملح و.الامن استقرا في افغـستـان ؟

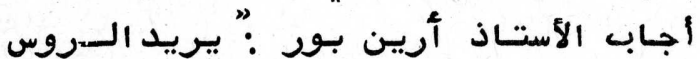

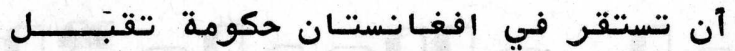
بنالسفريســات الـروسية عقبدة ومنهـاجـا .

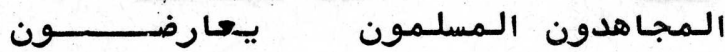

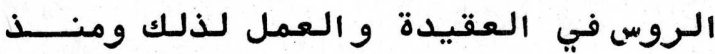

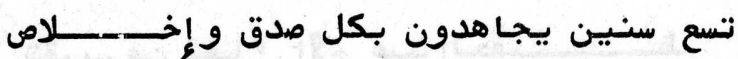
مع rنهم قدمو ا أكثر من مليون شهيد في سببيل اللله تهـالى فـالـمصالـة السمطروحة من قبل الروس وعملاعهم مستحبلـة الـنسـبسول من قبـل الشعب الافغـاني المسلـم "

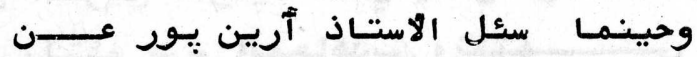

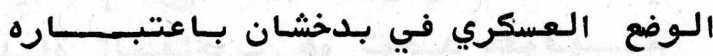

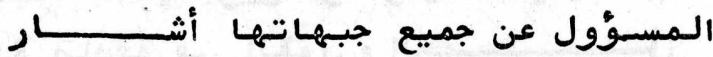
قـاعلا:" خــــلافـ لـلـمحافظات الاخرى توجد في بدخشان مشكلة ذات أهمية فـعقة وهــى
الحقوق،كمـا يقوي قولنـا هذا دلبيل آخـر

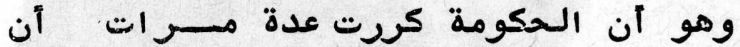
الـذين يـرجعون من خـارج أفغانستان إلـى

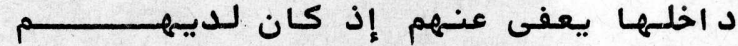
مسسؤوليـات وتسـاعدهم الحكومة بــمساعدات مالية • فتبسبن من خلال هذه التتصريحسات آن شعبن الذي أجبـز من جر اء ع الهجوم الاخمر على الـهجرة وترك الديبار إلى الديبـلاد

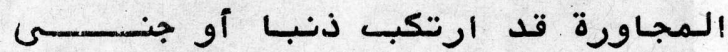

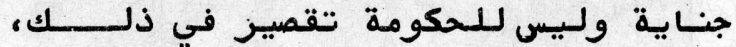
أو أن الـمجاهدين الذين يحساربون دفـاعـا عن دينـهم ووطنهم هم الـمقصرونو السمجرمون

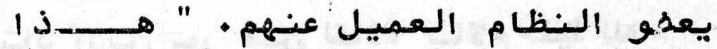

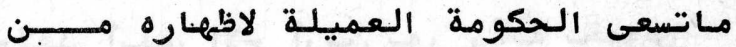

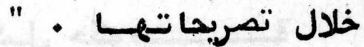
وعلى هذ 1 فـإن شعب افغانستان السمسلم السضطهد لـن يقبـل ذلة ولن يفضع عار الـمصالحة على جبينه السموسوم بعزة الاســلام وو اصل الأخ أرين يـور كلمته قـاعلا : إن

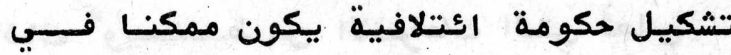
حالـة وجود امكانيـات للمسالسمة ،فى حبيسن •بوجد تضاد مطلقت بين الايمـان و الـكفر

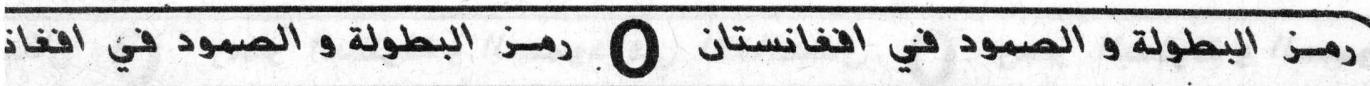
العدد التـاسع - السنة الثـانيـة - جمسادى الثـانية م مـاهـ 


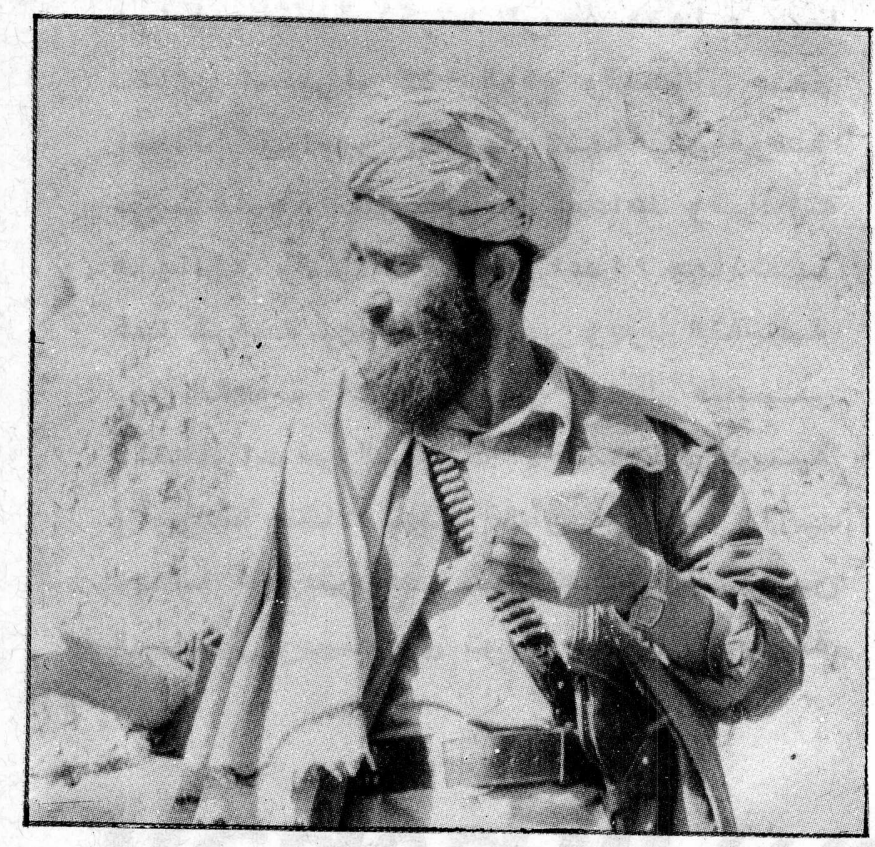

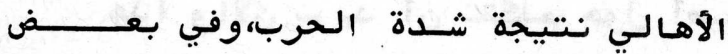

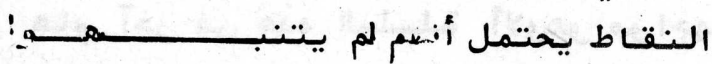

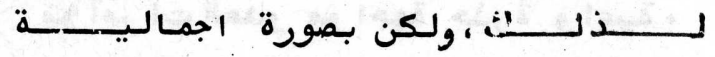

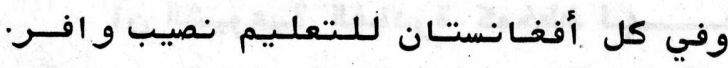

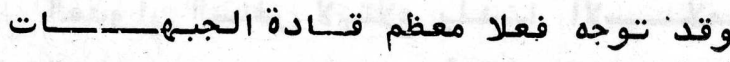

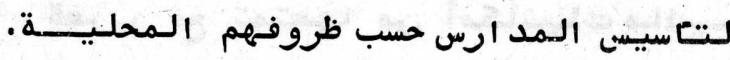

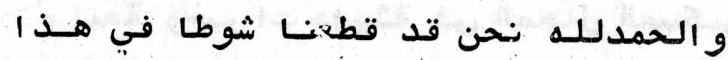

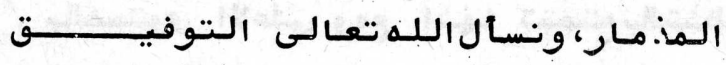
و.الحمـابية. فقد آسسن في كشم مدرسة من الصف الاوّل الى

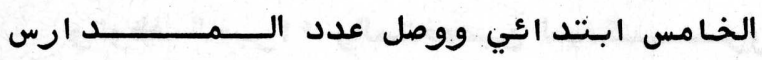

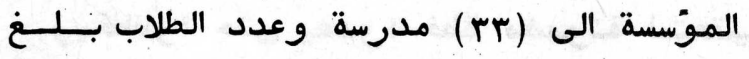
) (ro...)

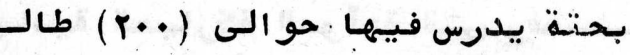

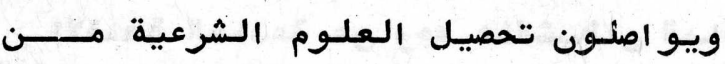

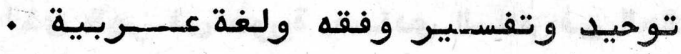

بعد الـطرق لـنقل الـمـتن ؤوعورتـهاوصعوبـة

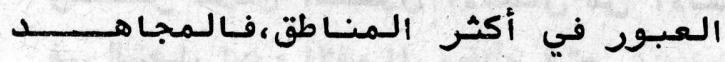

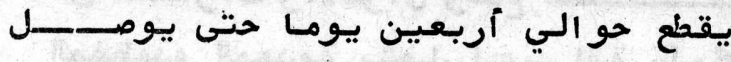

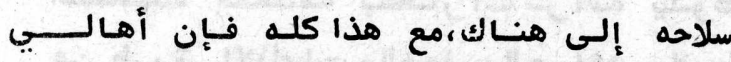

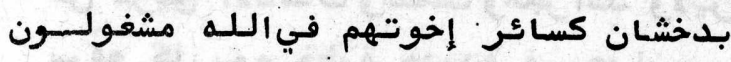

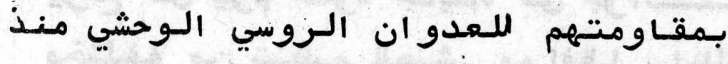

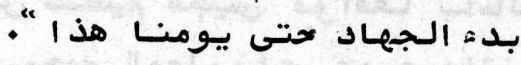

واثنـا \& الحديث عن فتح كلـفغـان صرح الاخ الاخ

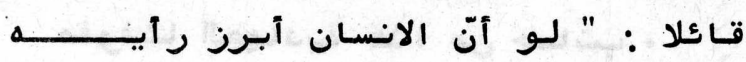

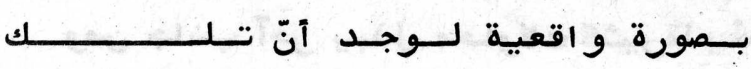

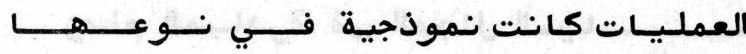

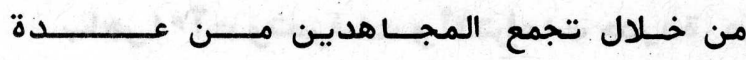

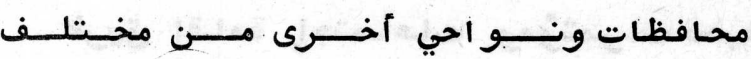

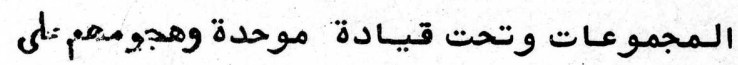
لـواء الـدو ومن شم فتح (الـمديرية )وهذا

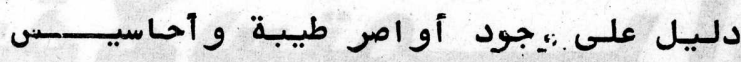

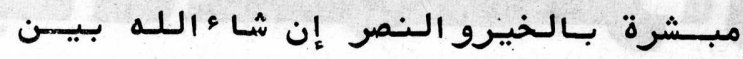
الـمجاهدين • لـقد ساهمت عمليـات كلفغـان

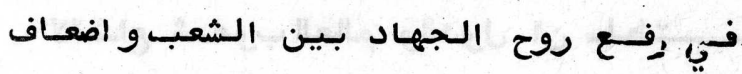

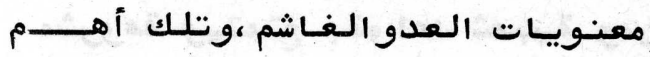

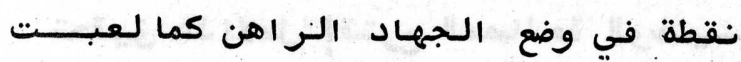

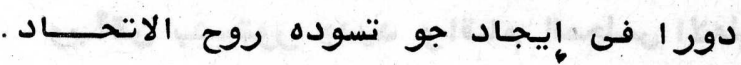

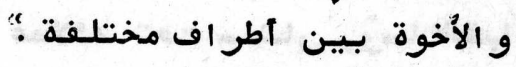

وقـال الأستـاذ آرين يـور :" إن مجلـــــس إنس

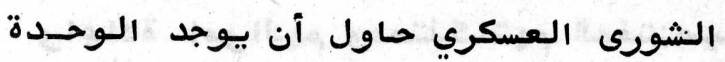

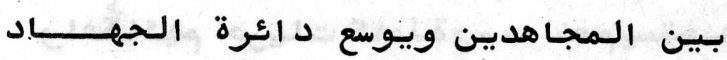

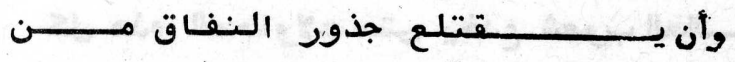

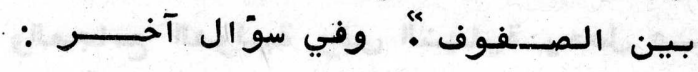

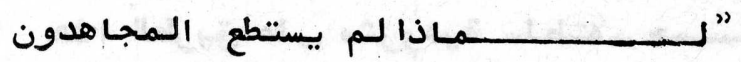

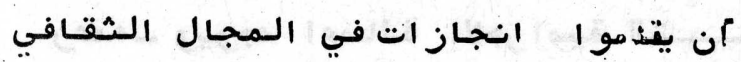

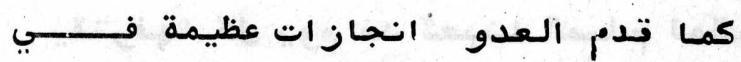

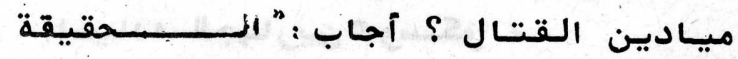

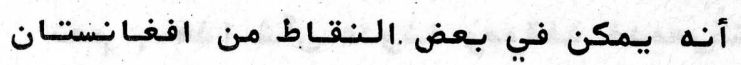

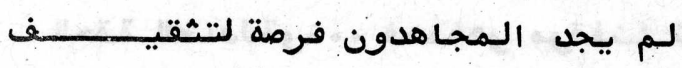

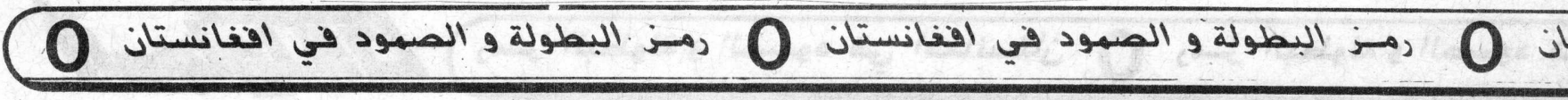


ومحب الانسـان فى المجتمعسات البشريةالراهنة

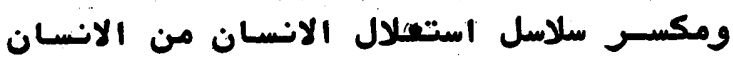

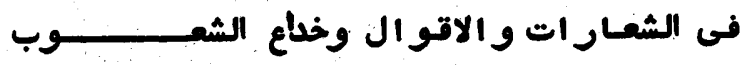

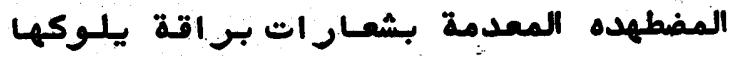

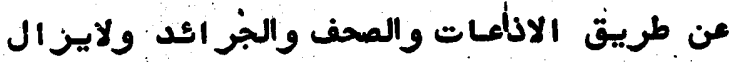

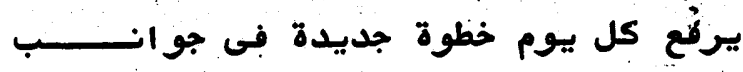

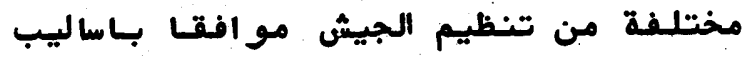

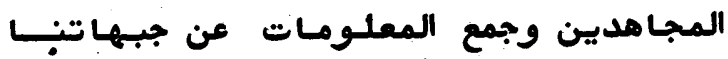

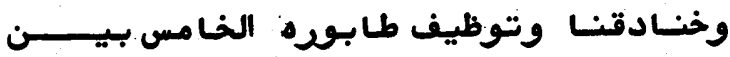

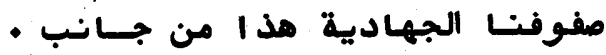

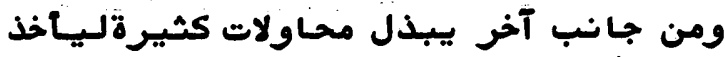

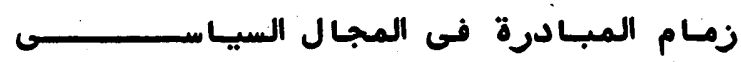

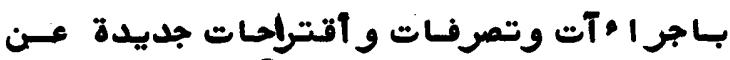

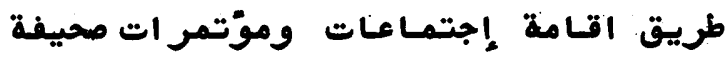

لـقد تكلمنـا فى العلقة السادسة مبـــن

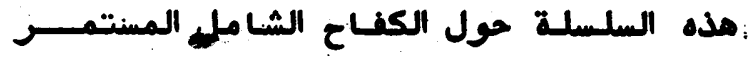

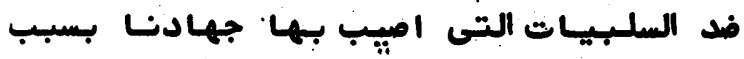

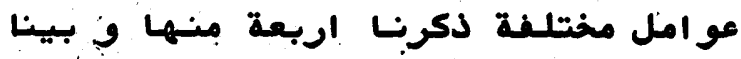

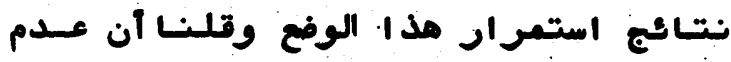

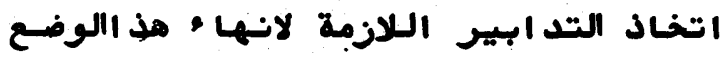

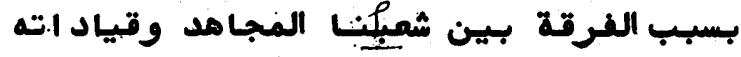

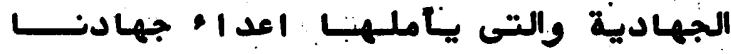

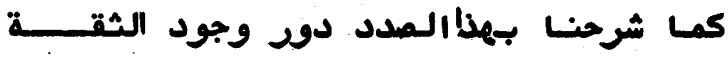

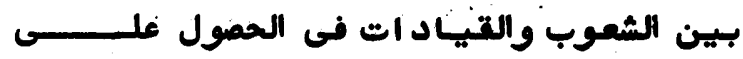

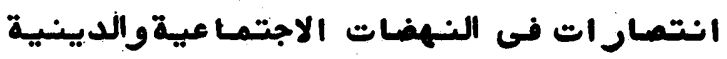

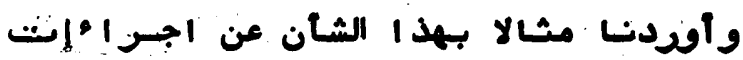

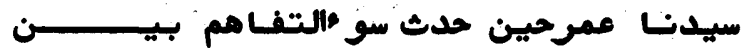

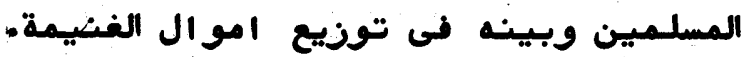

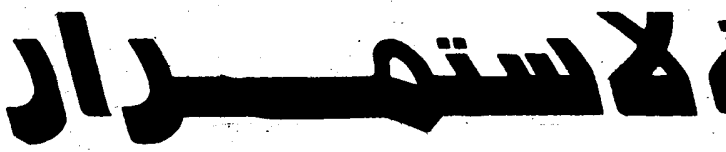
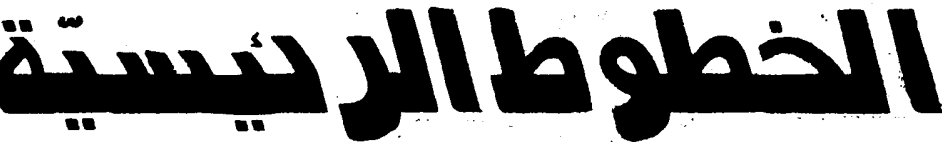

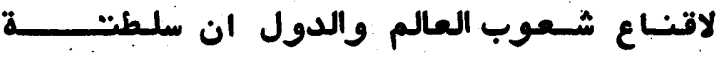

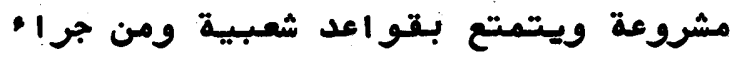

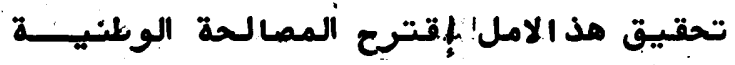

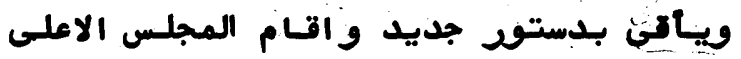

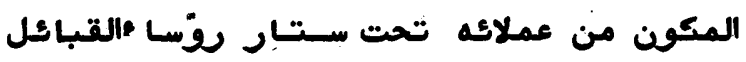
والشيوخ للتوقيع. على هذ الـدستور و أمسـدر

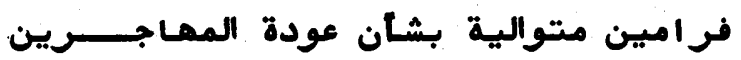
واعادة امو الـهم وممتلككاتهم المغتبِصيـه

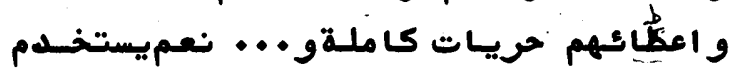

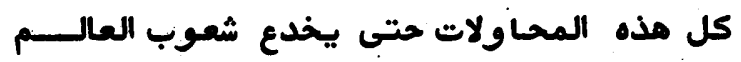

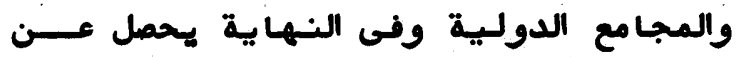

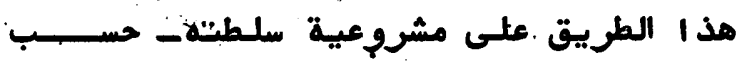

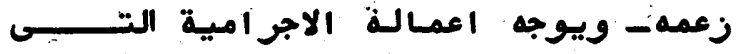
يقترفها كل يوم ضد شعبــا المسلـم لـمالـح

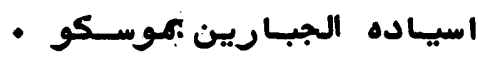
نعم : هذا شأن عدونسا وموقفة ضدمعرئنا

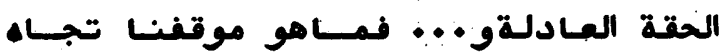

هذا و الآن نريد أن نتكلم حول أمسـل

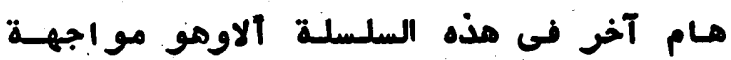

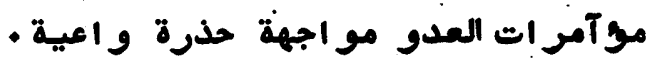

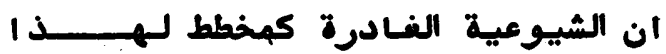

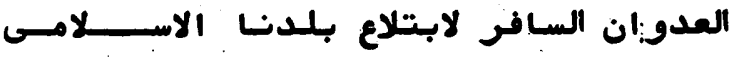

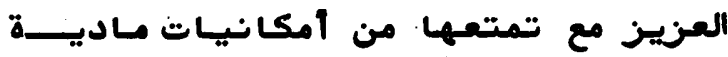
واسعة وخبر ات حديثة فى المجـال العسكـرى مئى بالمستوى الاعلى ومع انها وتيا تتمتع بالتنظيم

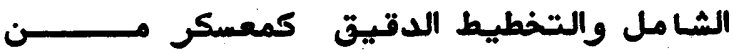

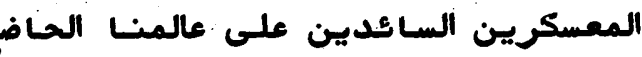

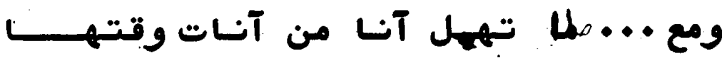

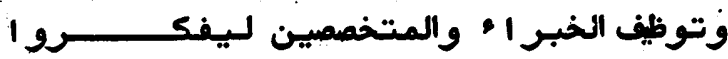
ويخططوا حتى يعدورا خطة مضمونة لـتحقيق

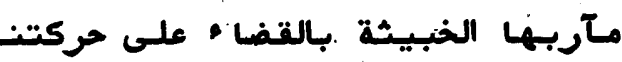

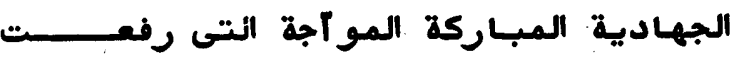
الاقنعة الخادعة عن وجه هذالشيطان المسكر

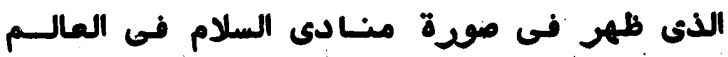

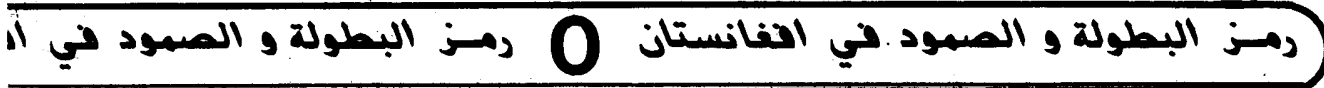




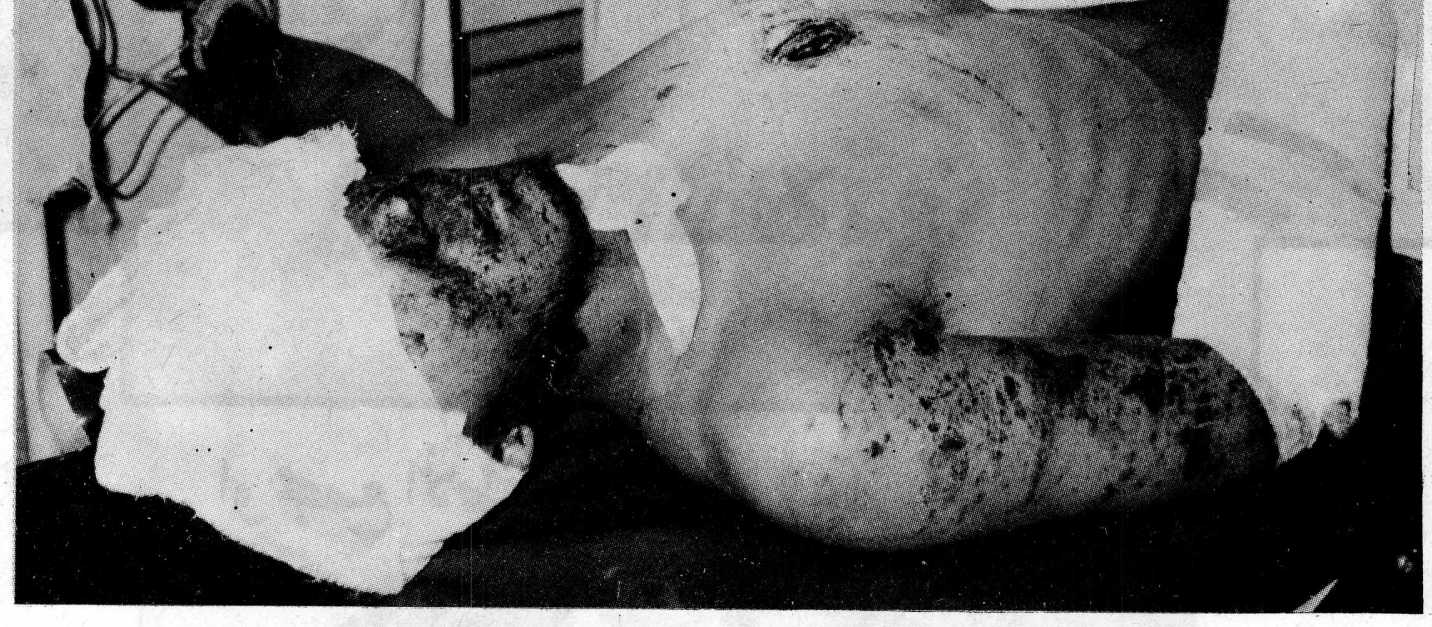

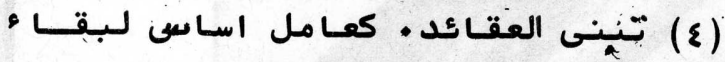

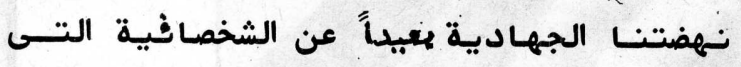

كل مـاذكرنـ عن المؤآمر ات التى اسـتخدمت

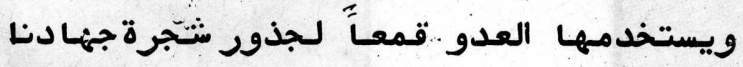

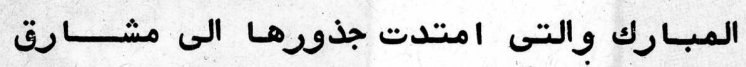
$\square$

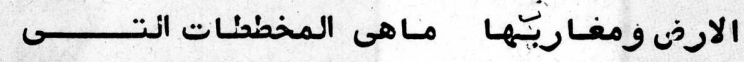
الحلـقـــــة الســـابعة

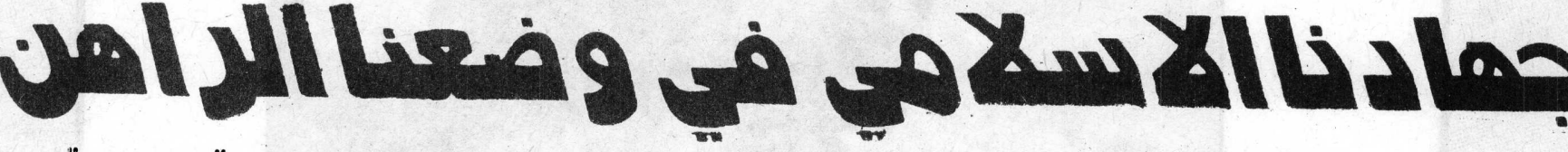

بقلـم الاستـاذ عنـايت الله " :ثاد اب "

توجه ضربة مميتة نحوكل حركهُتتبنـاهــا. (0) توثيق العلاقات بين القيـاد ات الجهادية

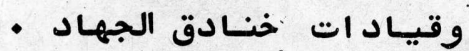
(7) توجيه الجبهـات الجهاديـة عن طـــريقت

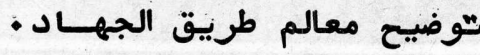

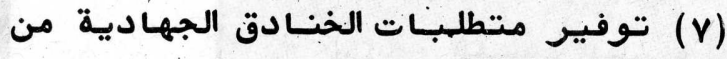

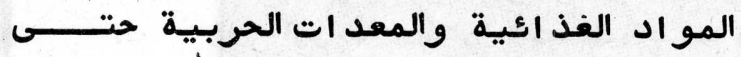

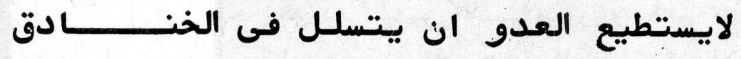

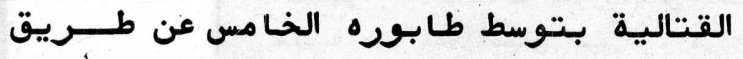

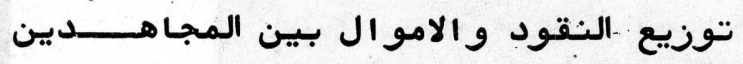

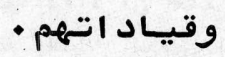

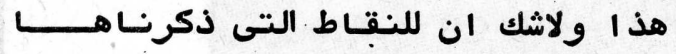
انفاتكون اشرا بـارزا فى انتمار جهادنا

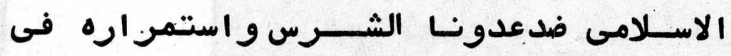

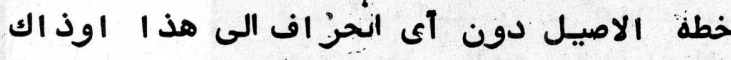

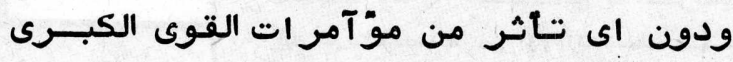

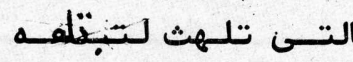

تقضى على هذه إلحيل ؟ ومـاهوالطريت لانقاذ

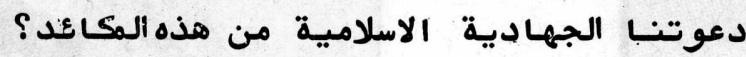

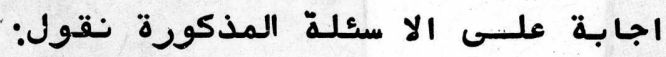

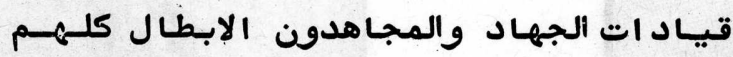

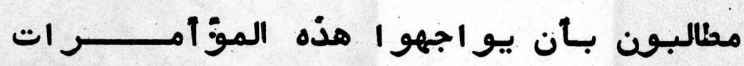

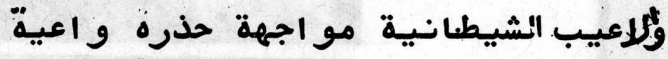

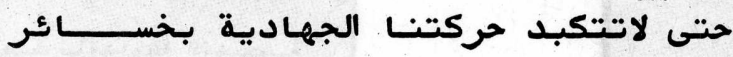

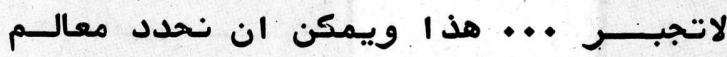

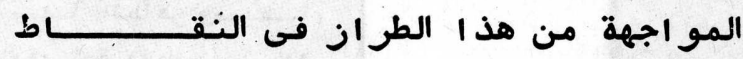

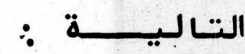
(1) ايضاح الطريق لاقـامة الدولـة الاسلامية

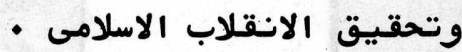

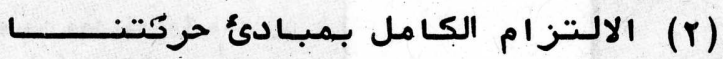

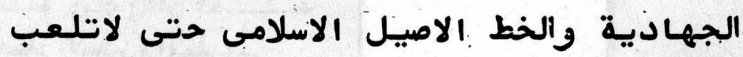

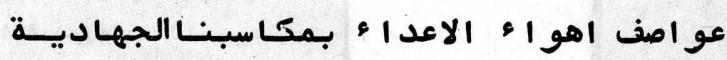

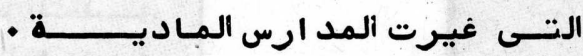

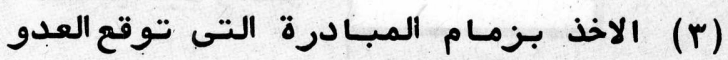

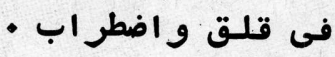

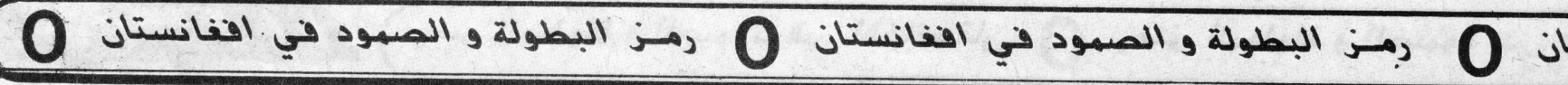




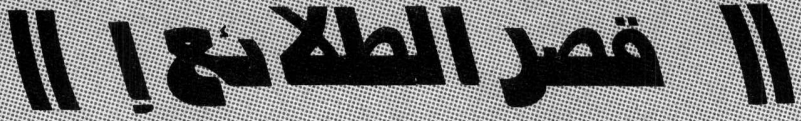

اوبمع الأطفال لتدريبهمعلى الجوسسة

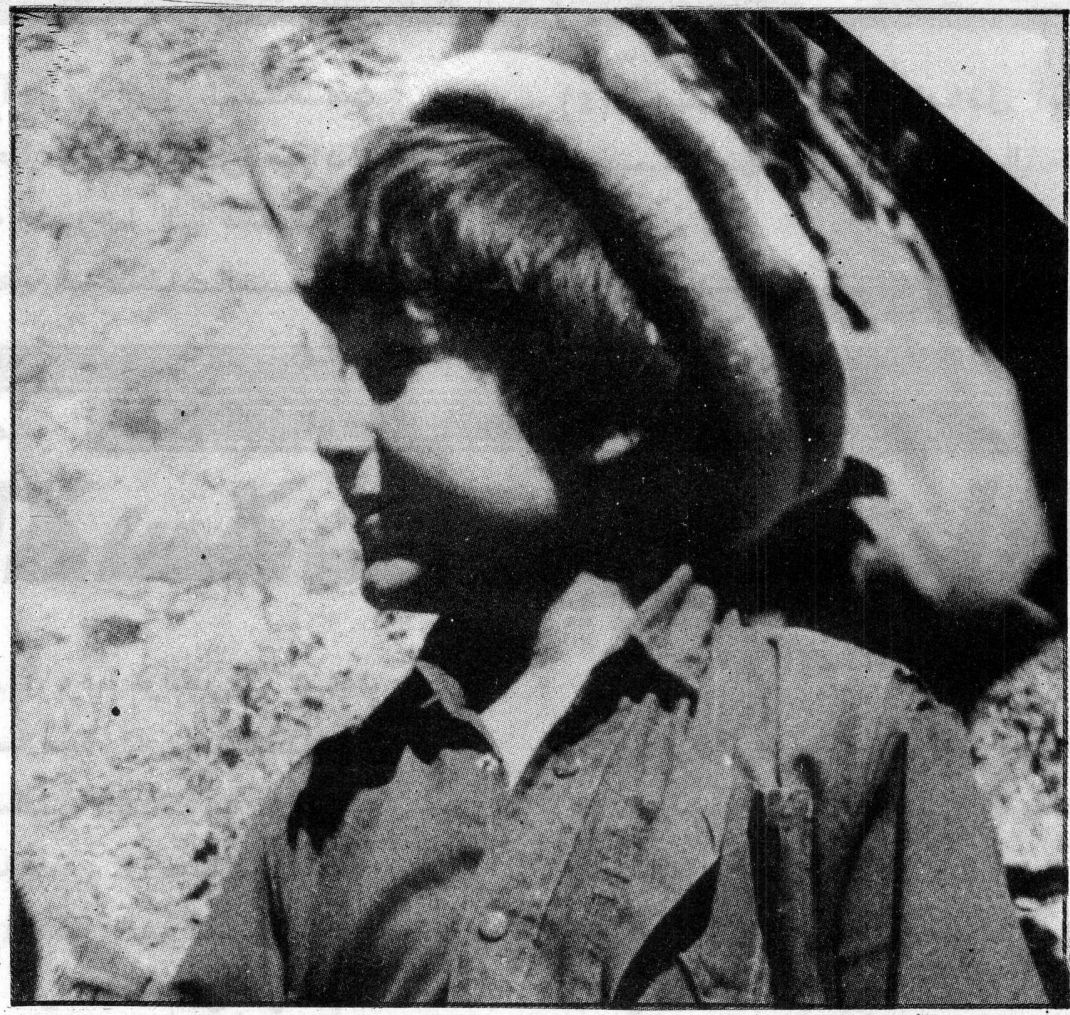

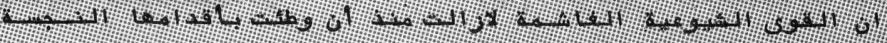

7

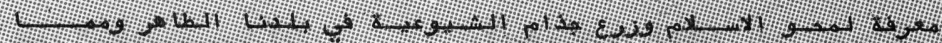
1

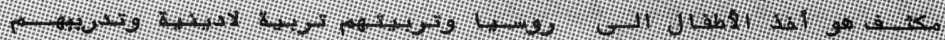
B

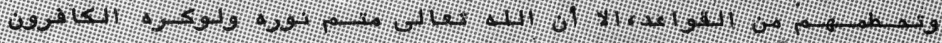
1 4.

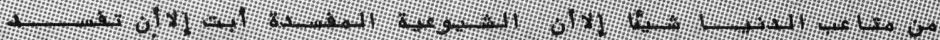

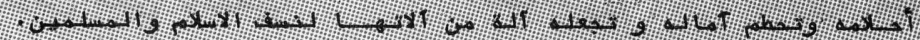

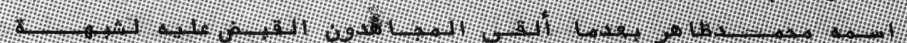

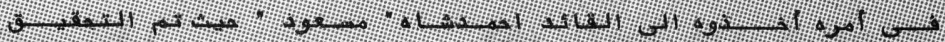

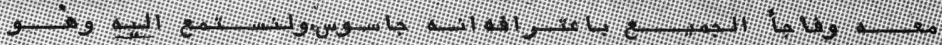
前 


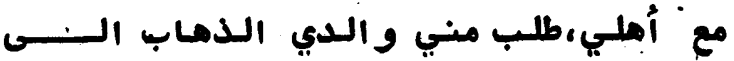

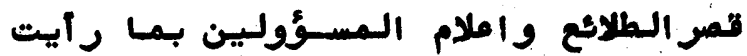

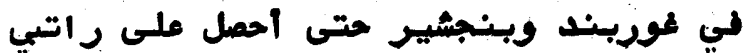

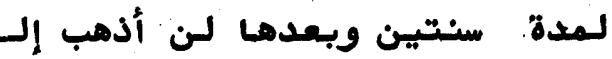

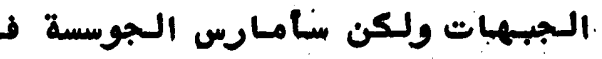

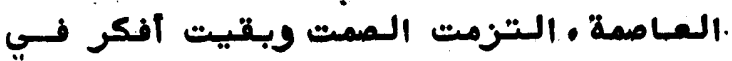

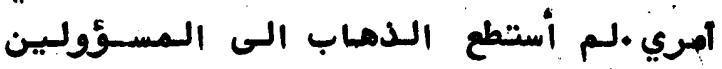

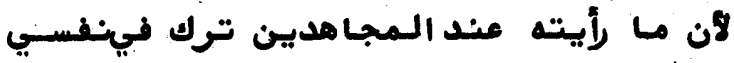
أشرا: كبيرا’ولسم أكن لافشي أسرارهم بعد فئد

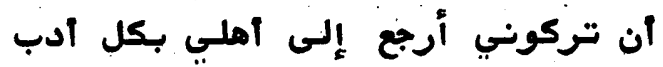

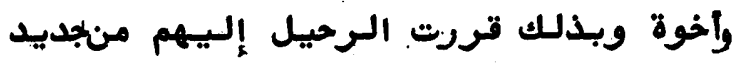

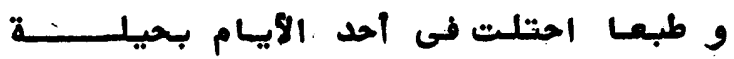

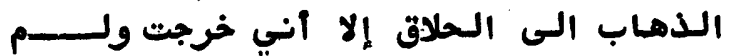

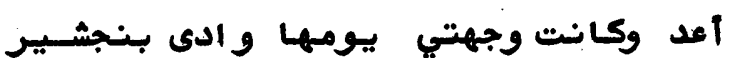

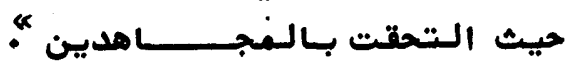
كانت هذه قمقة الـطل الـجاسوس اللذب مار

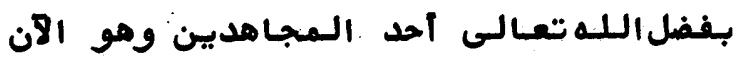
من حملة الـقر آن الـكريم حيث حفظه خـــلال

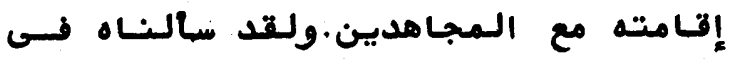

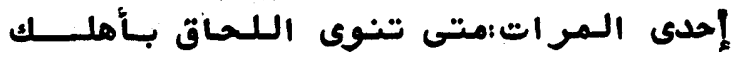

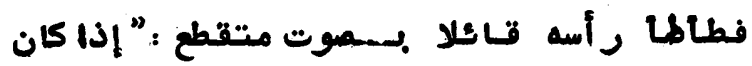
أهلي مسلمين فسياتون هنـ و إن لـميكونوا

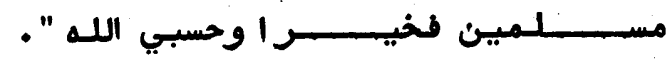
اخي القارئ ؛ مذا نموذج بسيط لالاف الاطفال

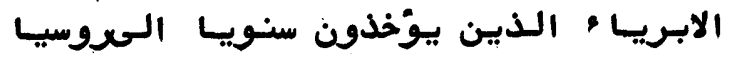
لغسـل أدمغتهم وتربيتهم ترببية إلحسادية

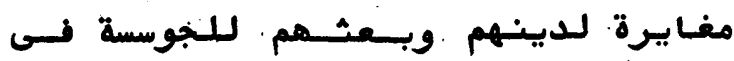

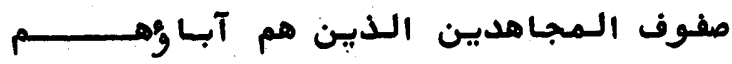

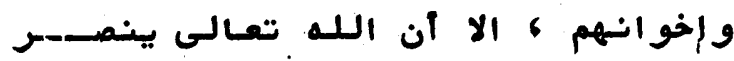

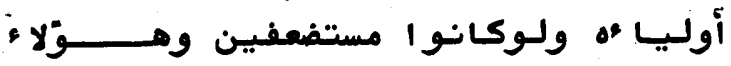

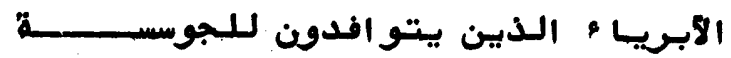

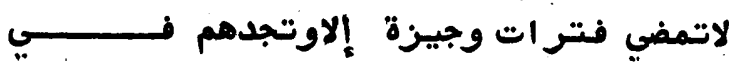
مفوف الـمجاهدين يبذلـون دما عممو ارواههم

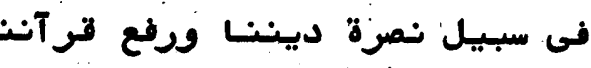

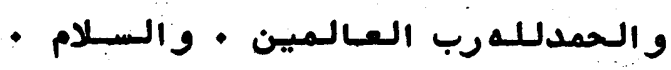

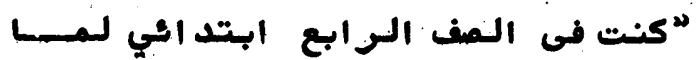

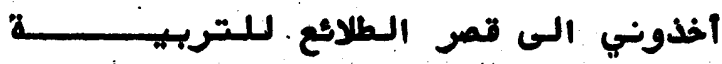
الجاسوسية ومنـاك الخدات أواعل دورسيسي

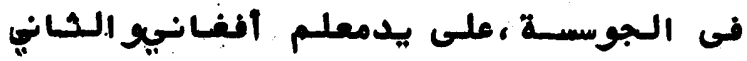

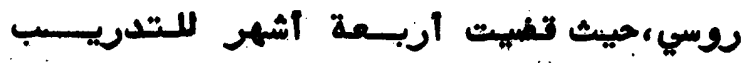

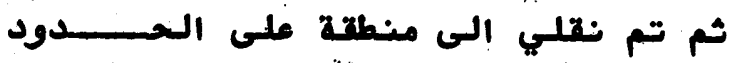

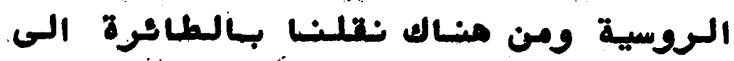

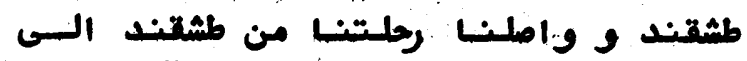

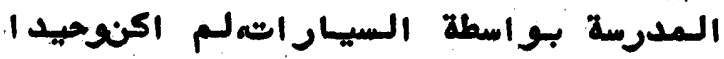

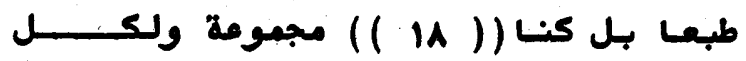
واحدة نحو ، (10) طفلا،فكن تقريبـاحوالي (YV•)

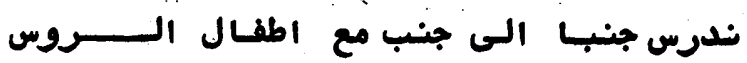

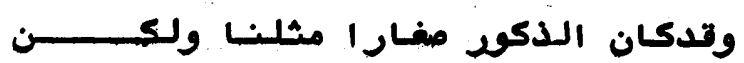

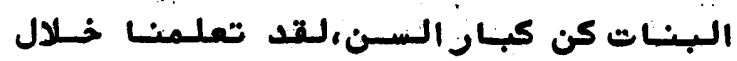

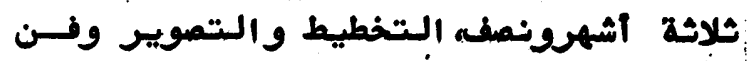

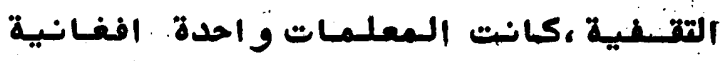

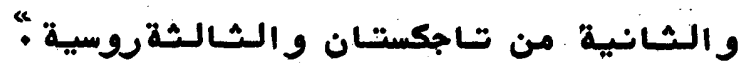

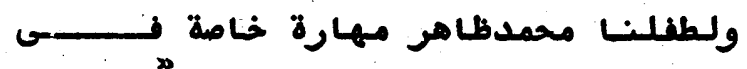

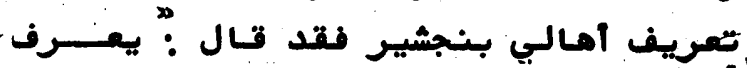

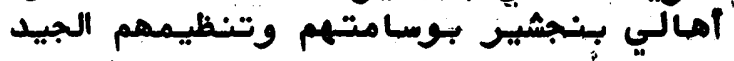

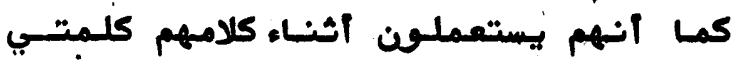

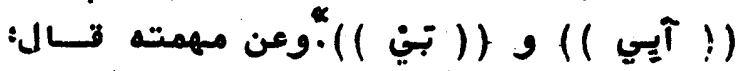

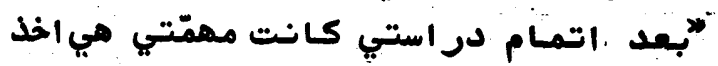
البمخططات وكل المعلومهات عن و الدىغوربند

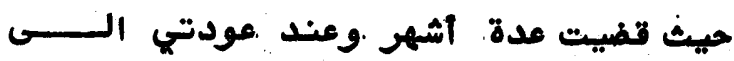

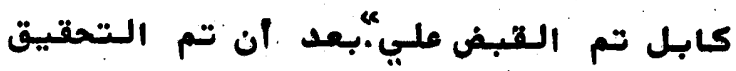

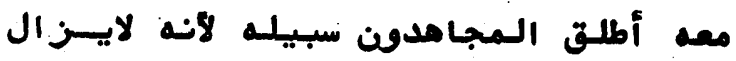

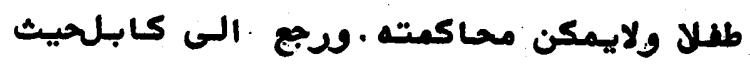

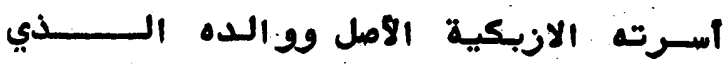

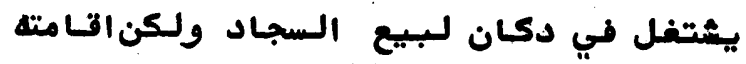

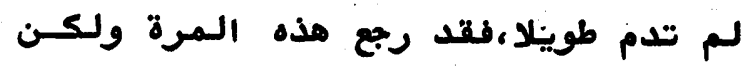

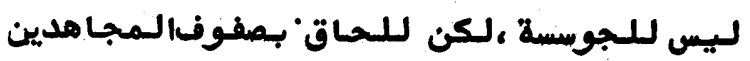

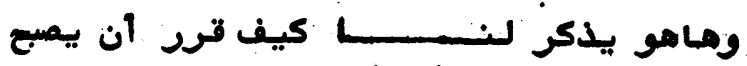

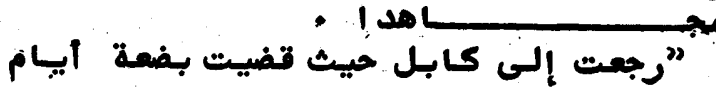




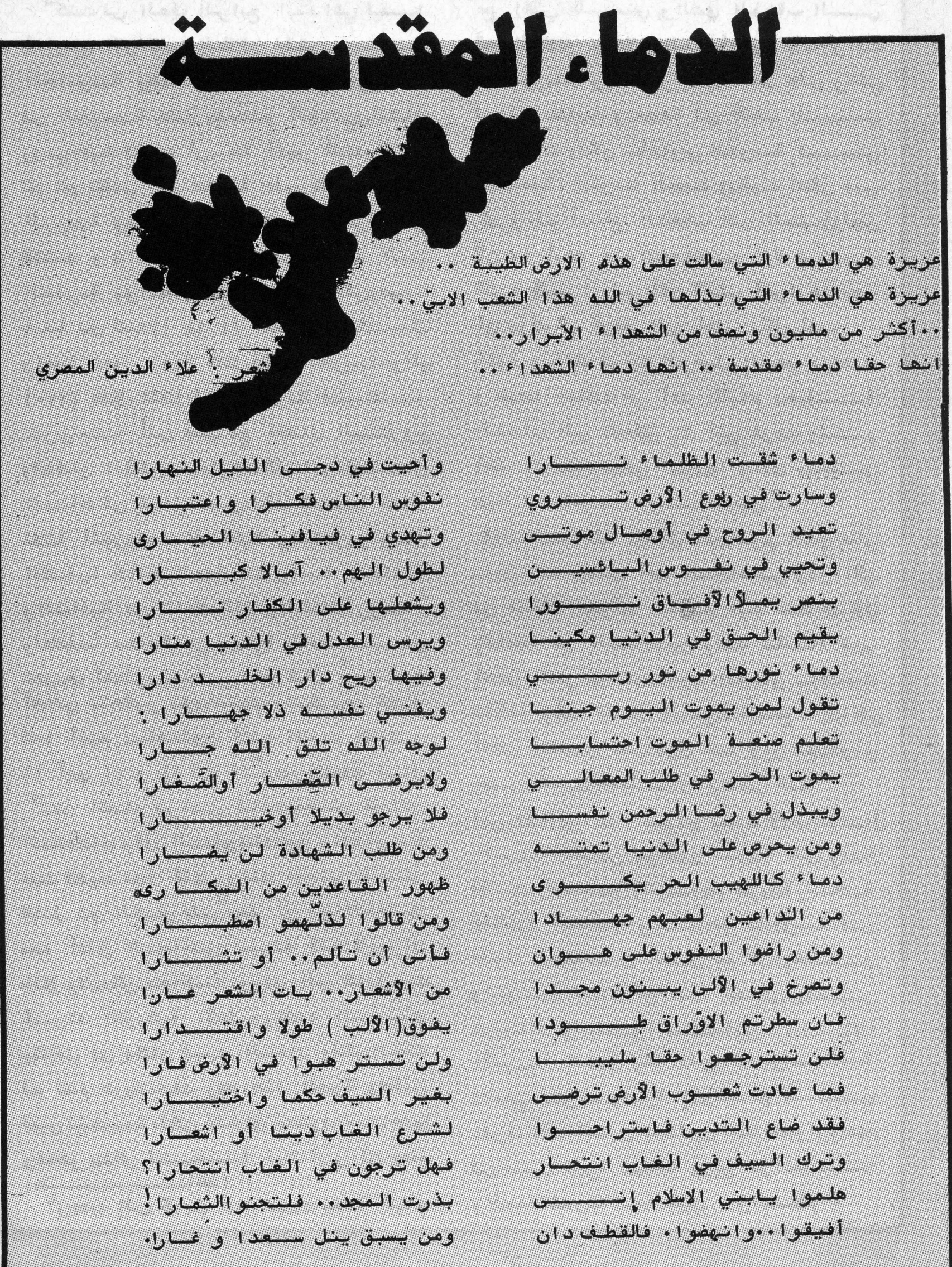

رم-تز البطولة و الصهود في الفانسبتان 0 رمـز البطولة و الصهود في اه 
بشير حمزه

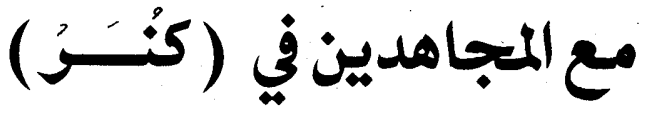

قدتستغربوا وكدلاتمدقوا ما أنــــول

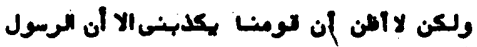

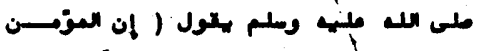

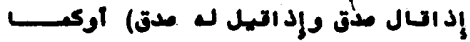

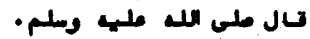

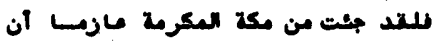

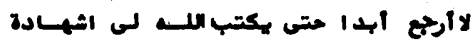

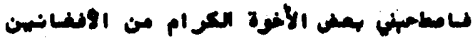

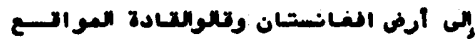

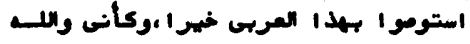

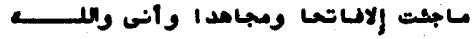

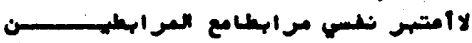

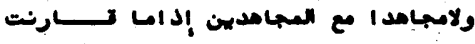

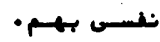

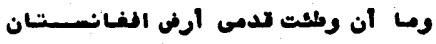

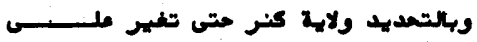

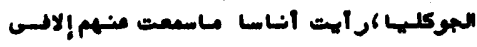

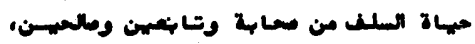

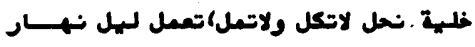

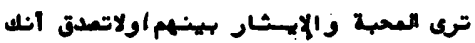

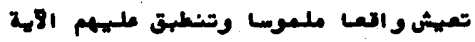

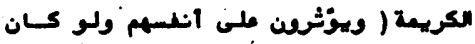

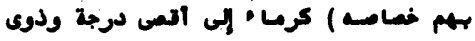

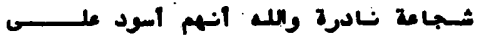

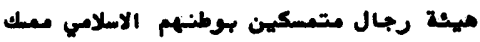

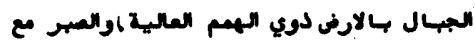

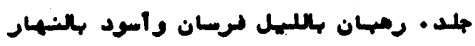

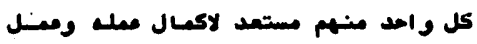

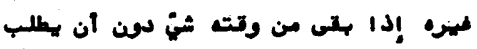

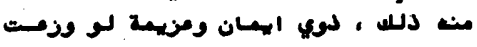

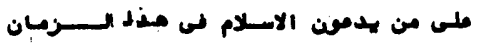

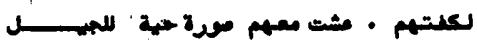

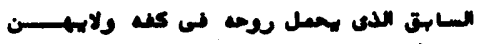

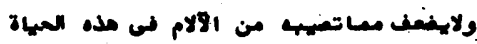

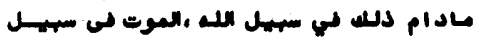

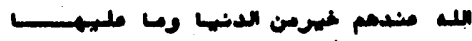

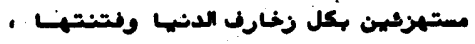

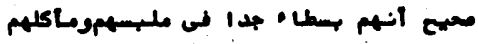

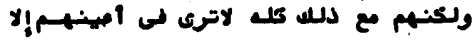

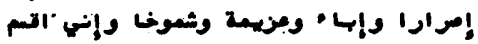

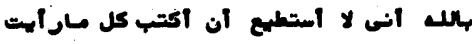

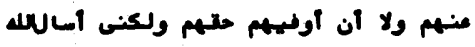

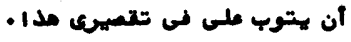

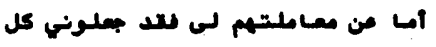

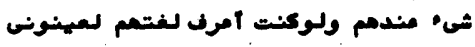

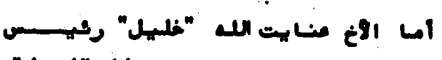

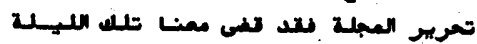

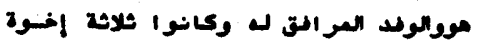

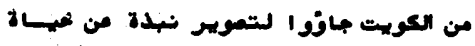

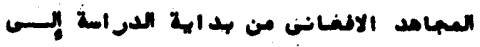

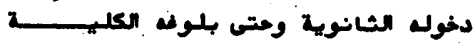

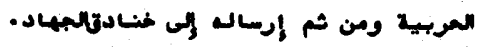

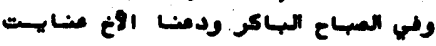

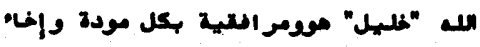

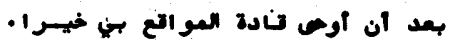

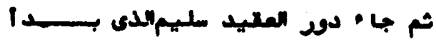

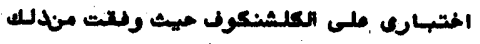

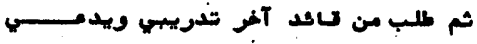

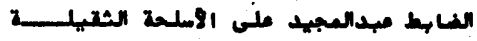

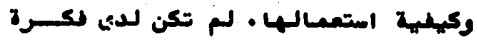

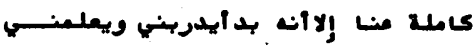

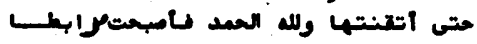

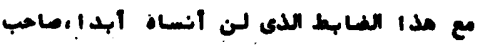

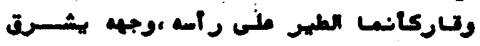

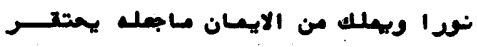

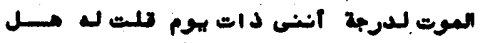

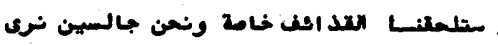

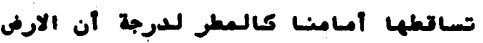

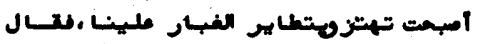

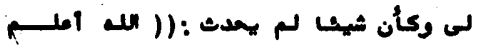

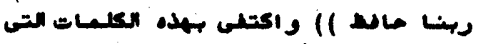

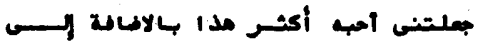

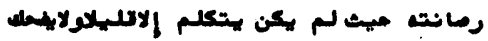

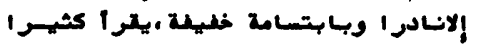

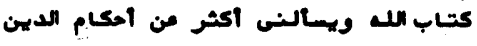

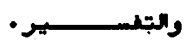

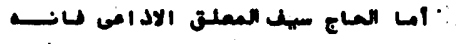

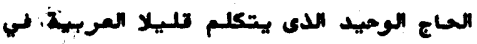

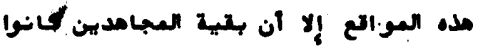

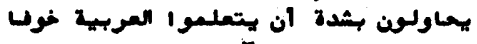

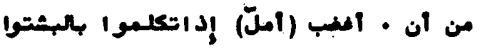

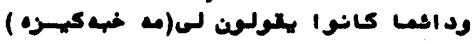

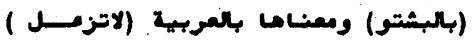

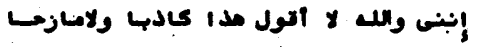

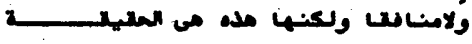

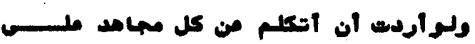

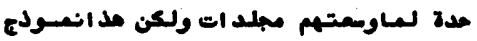

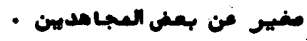

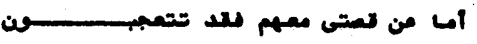

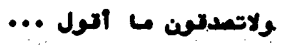

بدابخ رملتهـى :

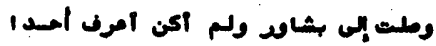

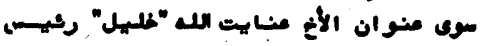

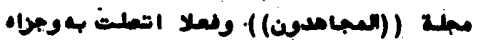

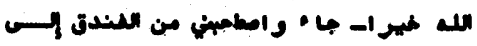

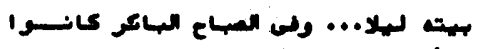

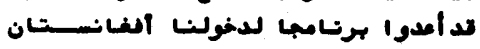

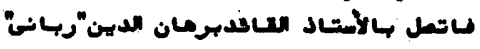

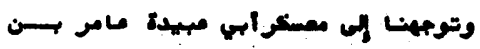

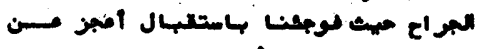

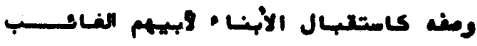

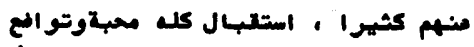

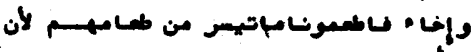

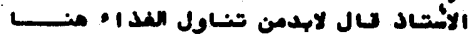

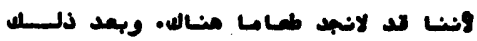
مهاثرة توكلن ملف الله تامدهن - ولاهية

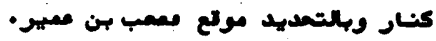

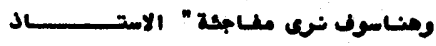

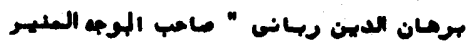

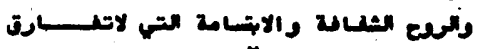

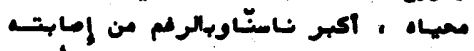

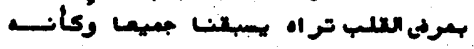

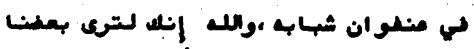

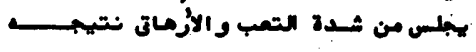

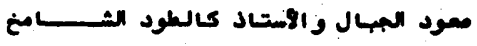

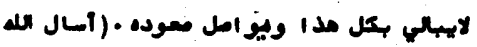

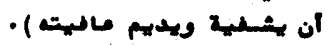

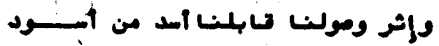

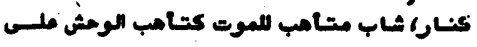

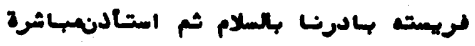

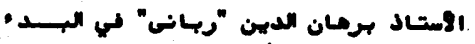

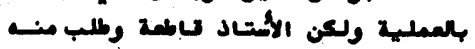

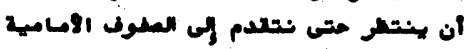

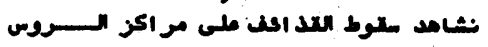

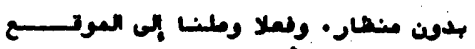

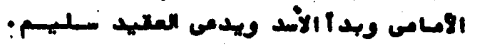

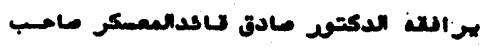

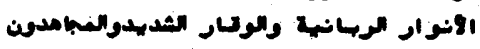

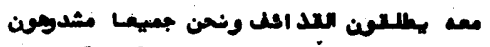

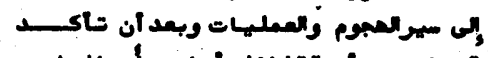

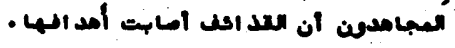

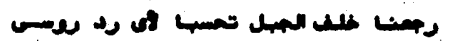

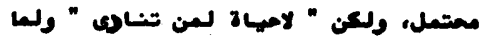

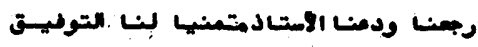

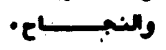



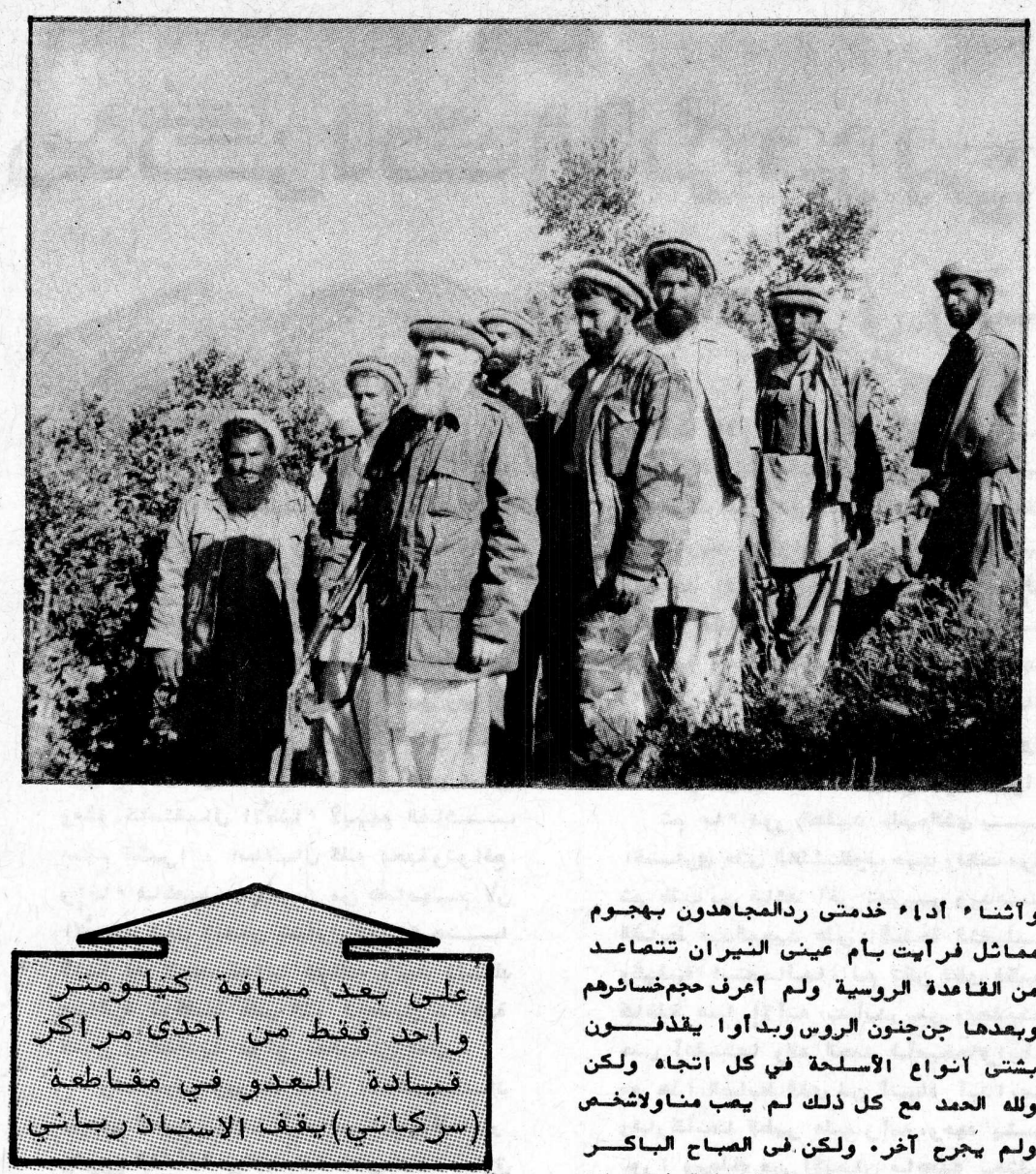

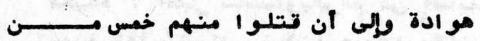

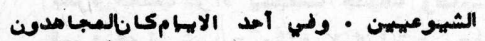

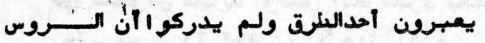

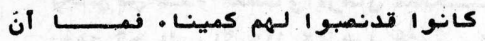

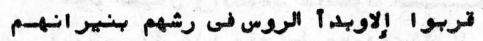

وآثنا • اد إ خدمتى ردالمجاهدون بهجهوم

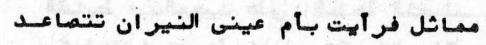

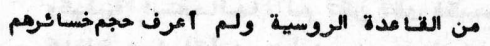

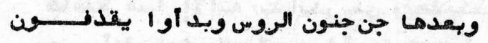

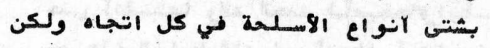

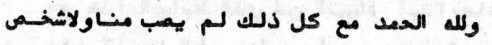

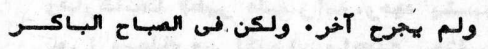

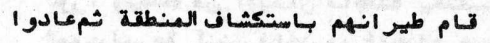

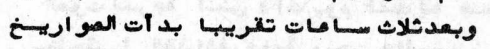

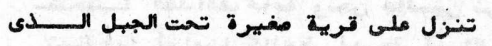

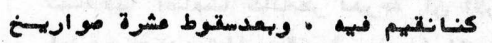

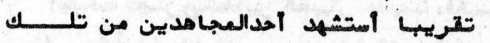

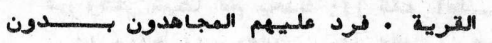

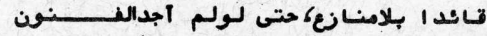

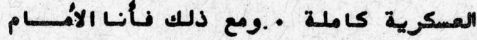

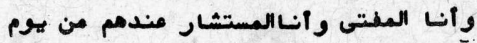

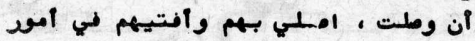

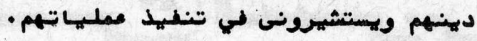

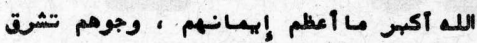

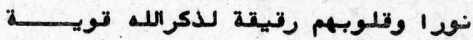

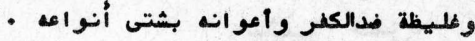

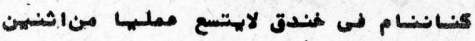

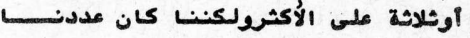

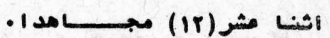

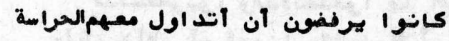

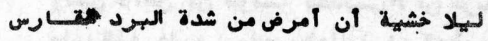

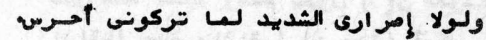

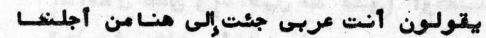

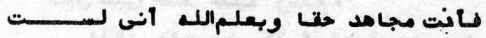

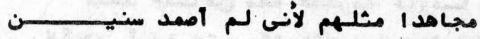

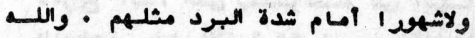

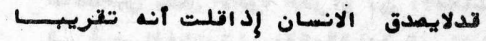

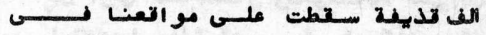

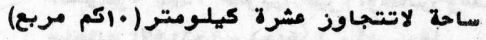

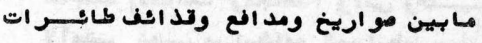

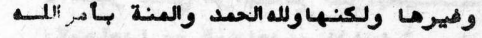

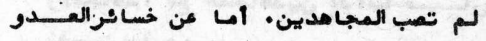

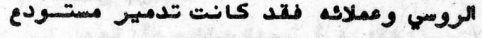

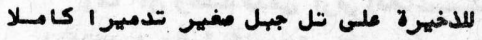

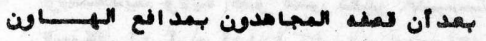

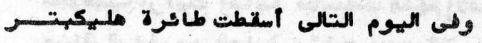

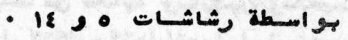

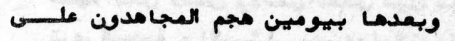

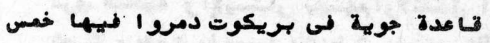

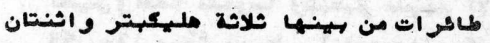

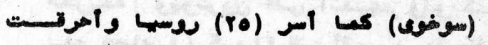

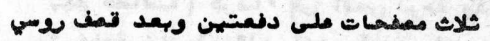

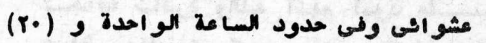

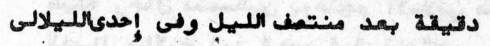
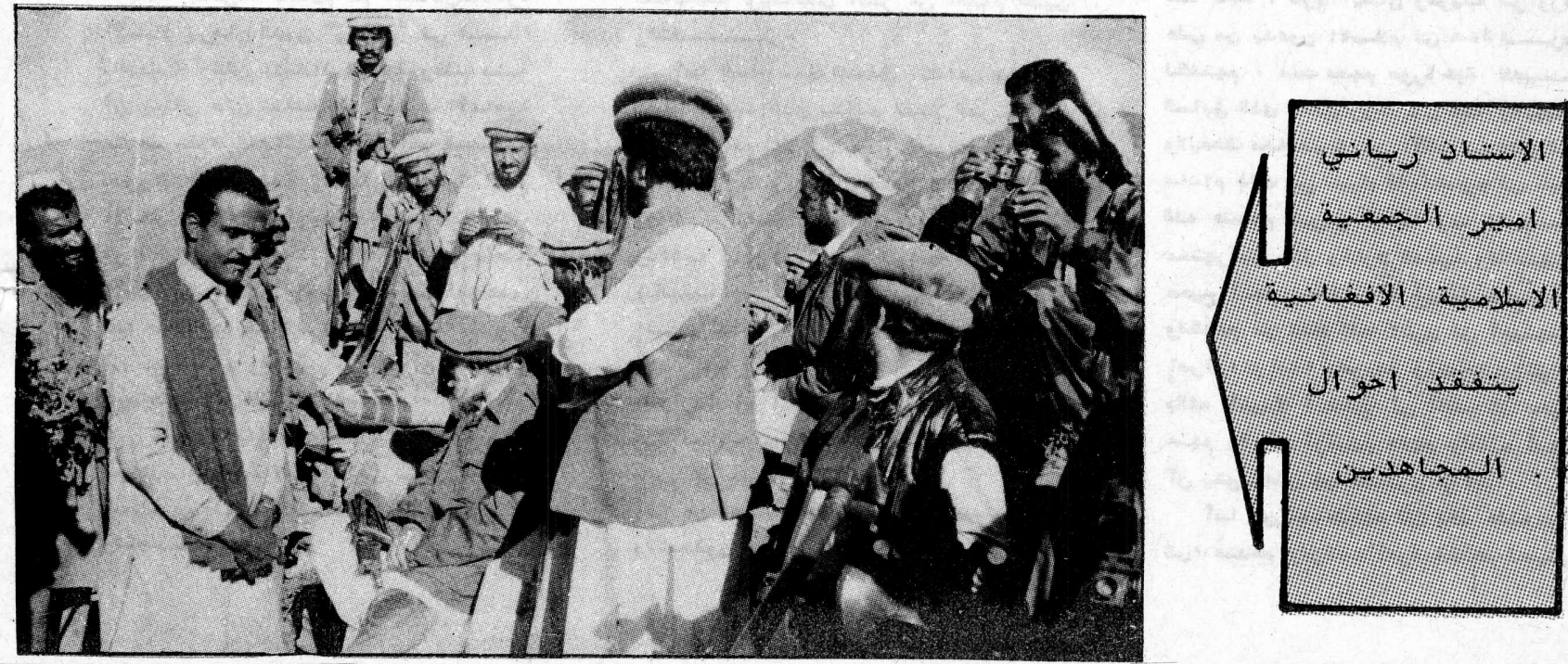


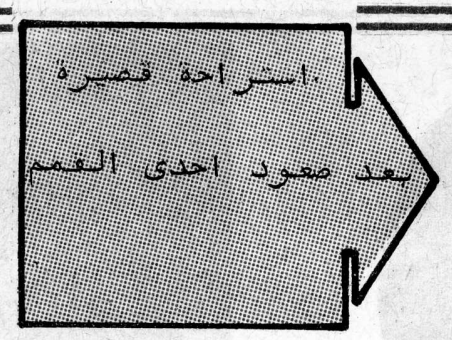

سيطونون مابخلوابه يوم القيامة )||

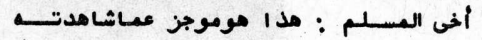

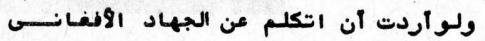

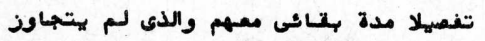

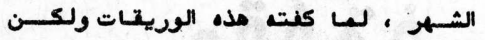

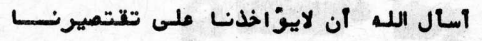

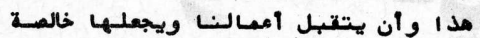

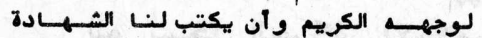

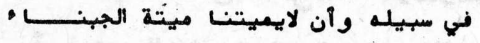

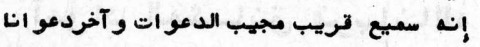

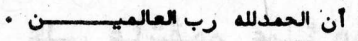
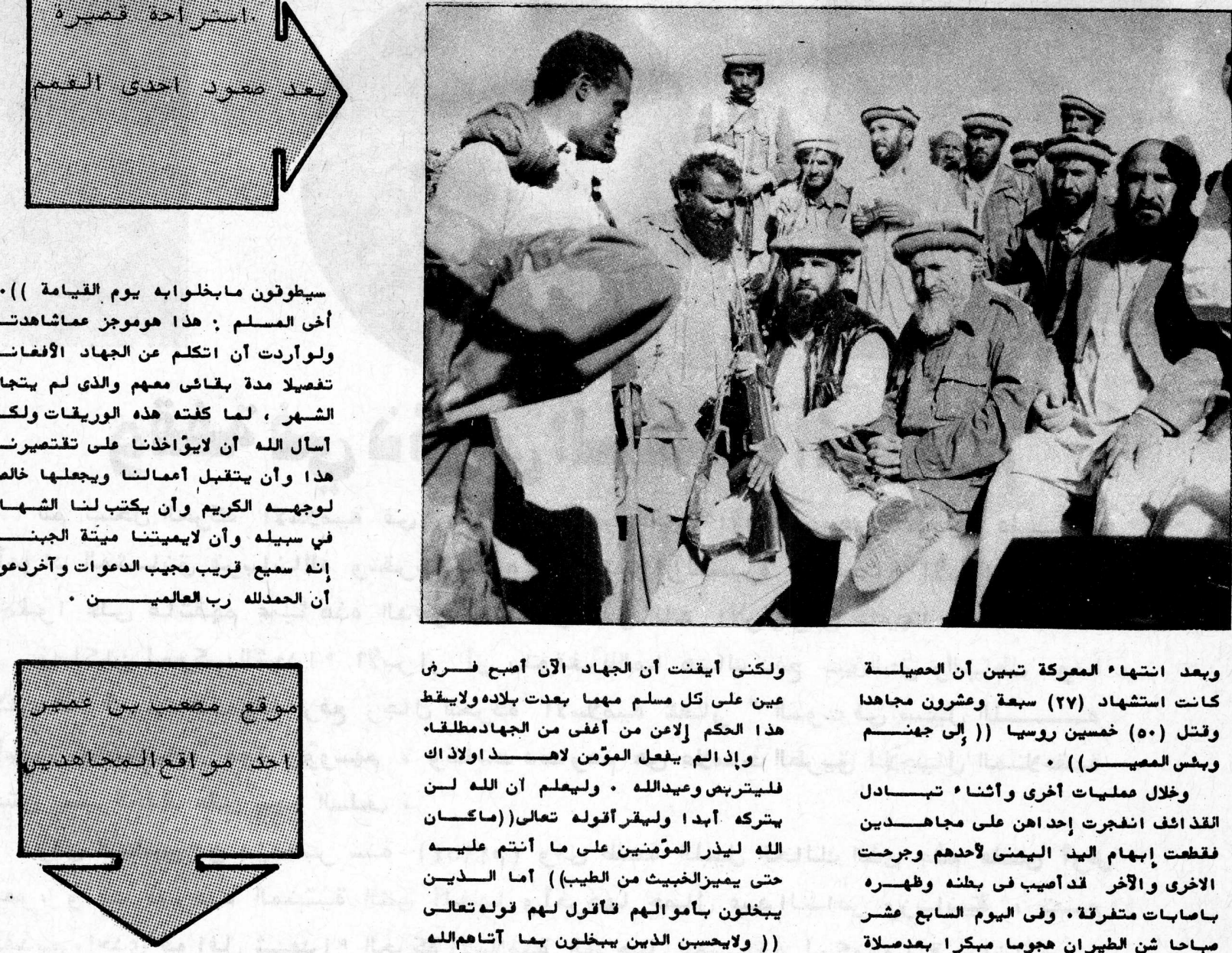

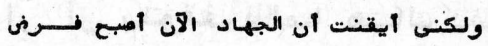

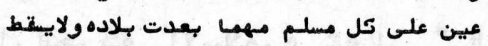

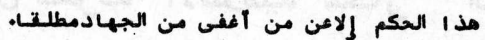

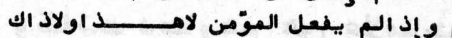

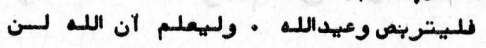

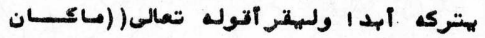

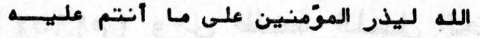

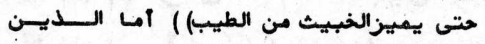

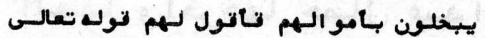

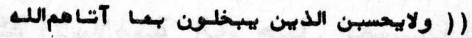

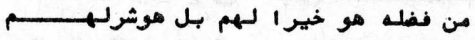

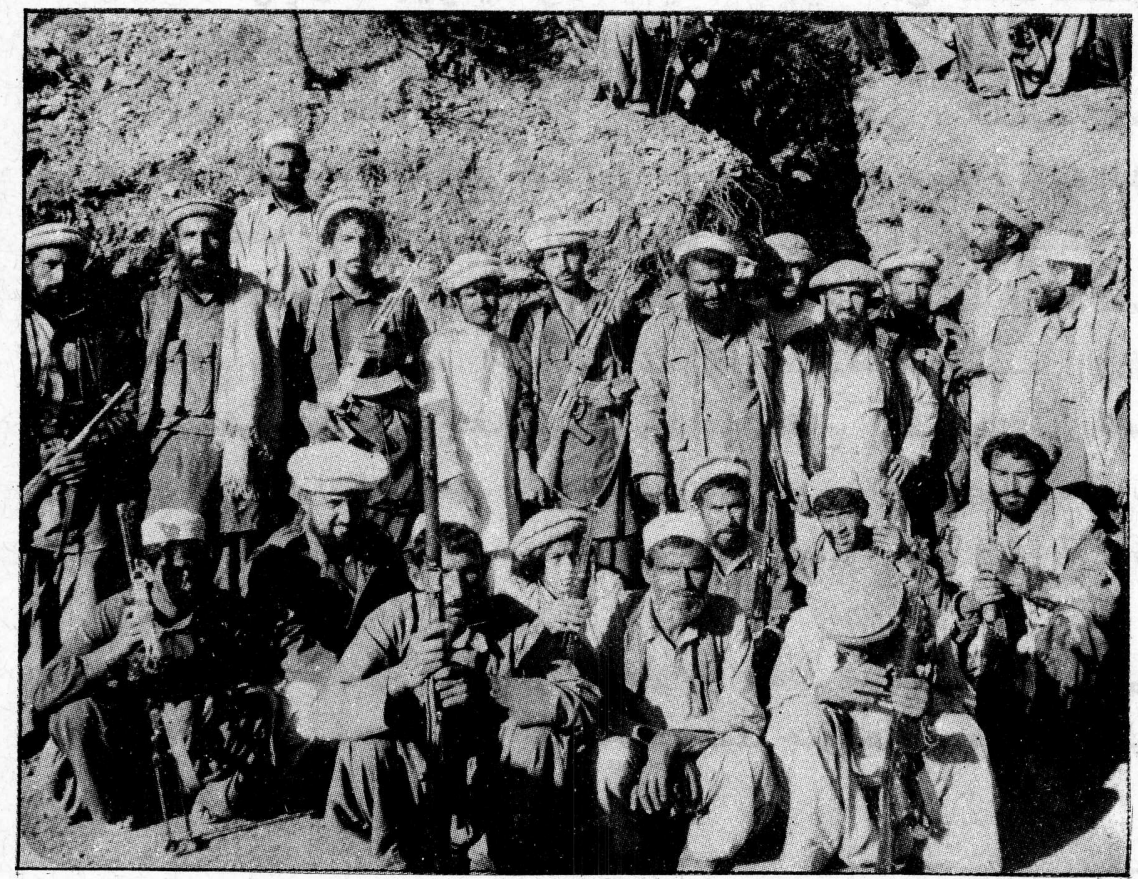

وبعد انتها • السعركة تهين ان الحصيلــــــاد

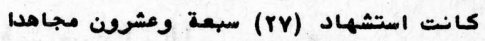

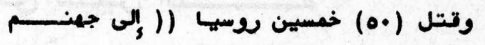

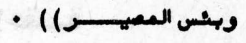

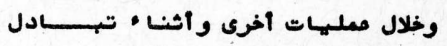

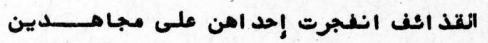

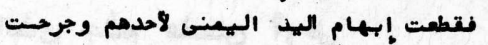

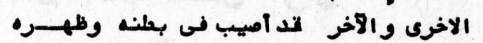

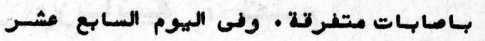

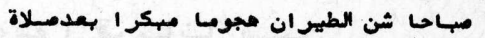

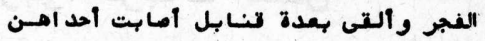

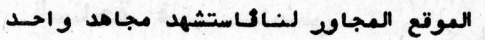
حتى أن جسعه كله حثق وأضيب خمسة آخرون

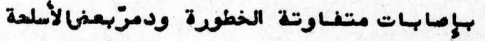

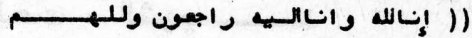

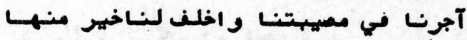

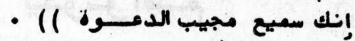

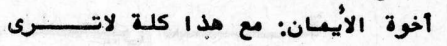

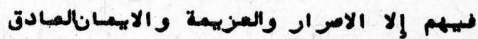

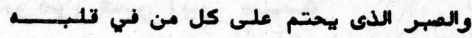

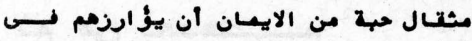

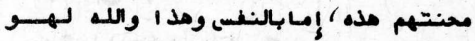

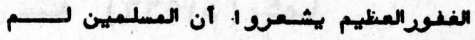

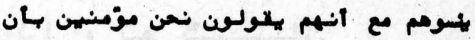

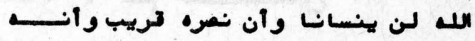

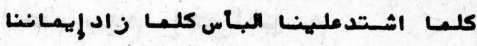

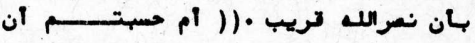

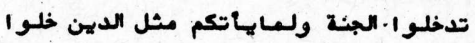

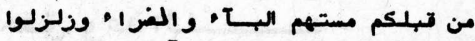

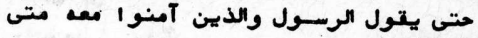

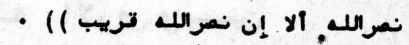

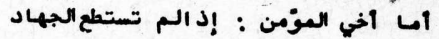

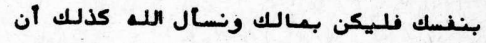

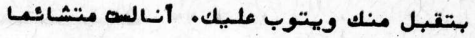

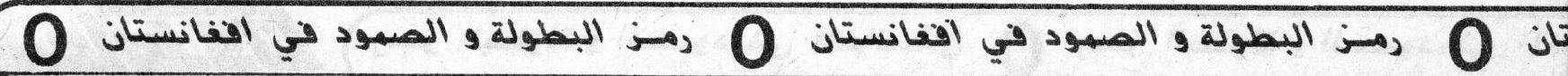



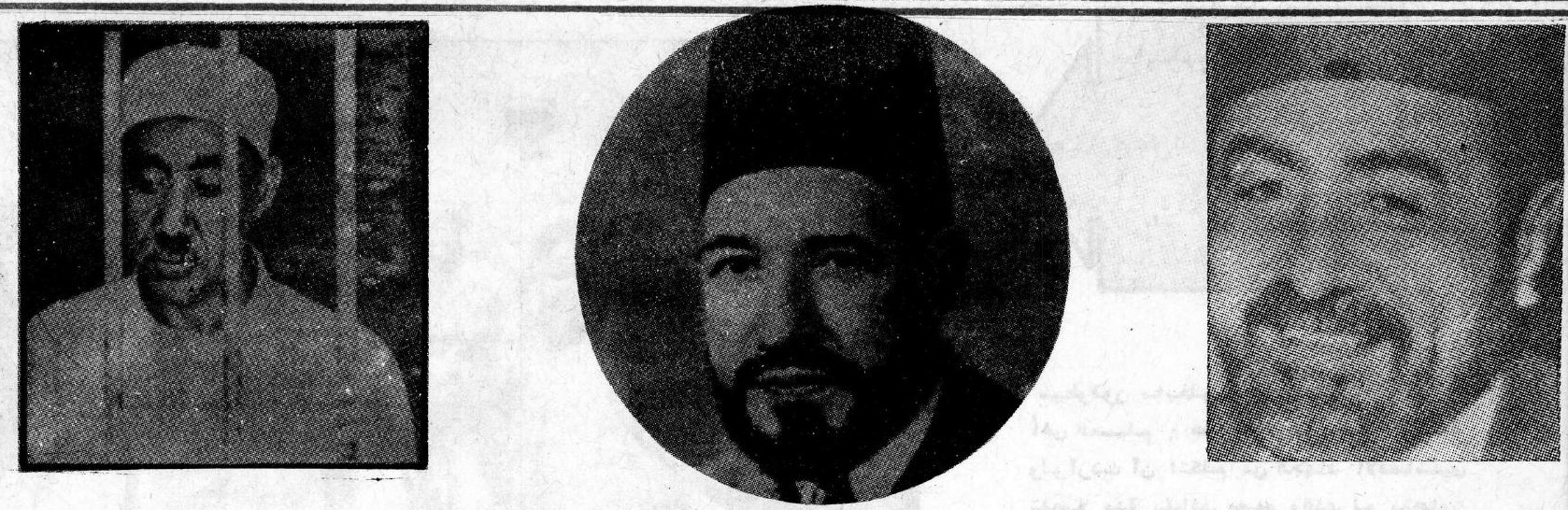

\section{وقفمة في نكرى الشهداء العظلمام}

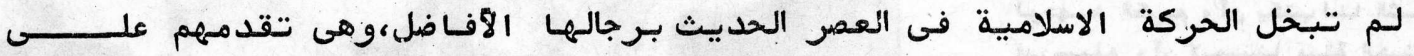

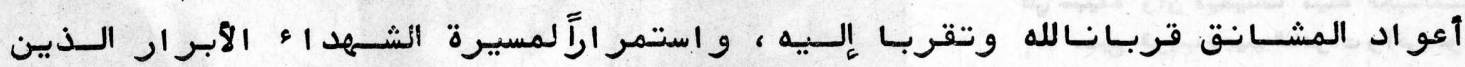

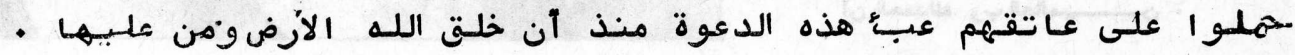

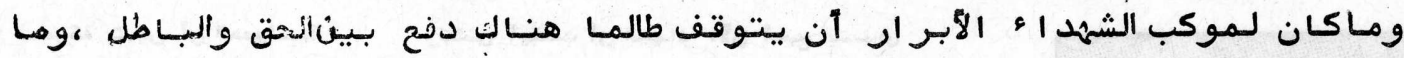

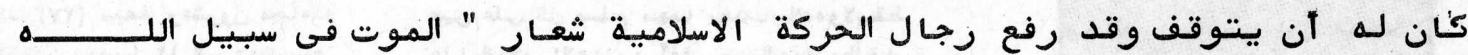

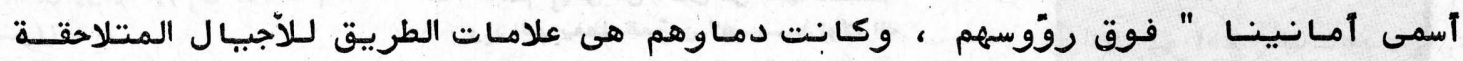

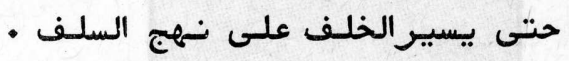

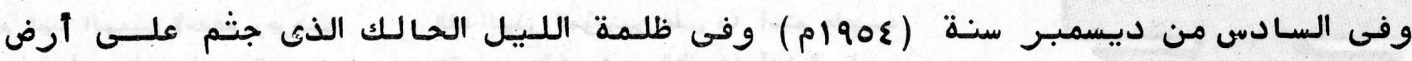

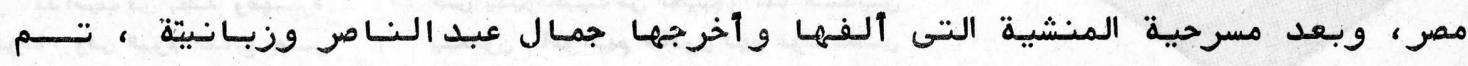

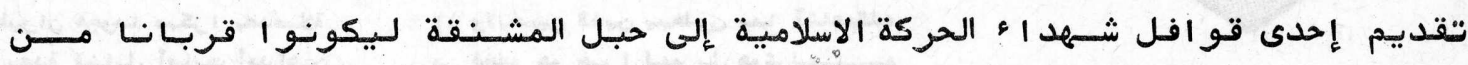

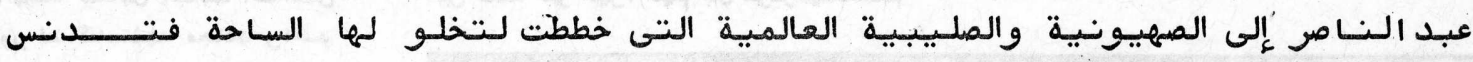

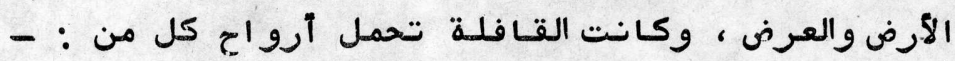

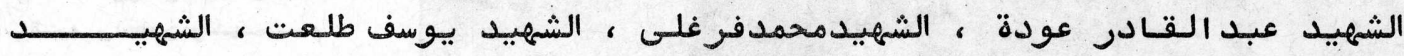

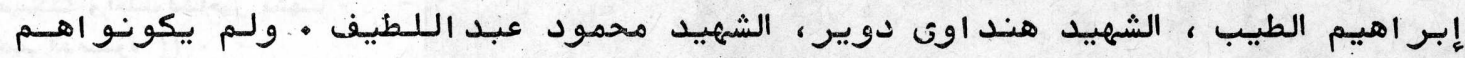

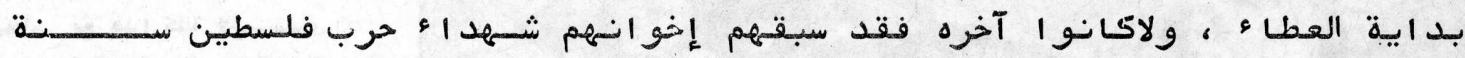

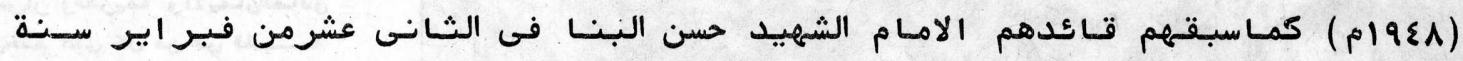

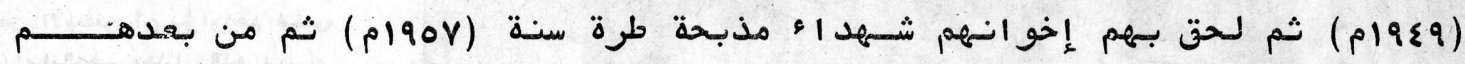

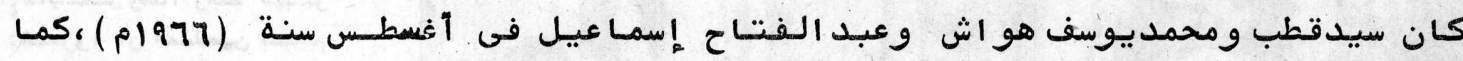

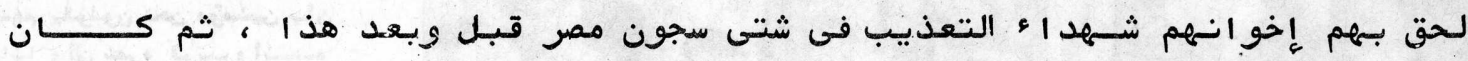

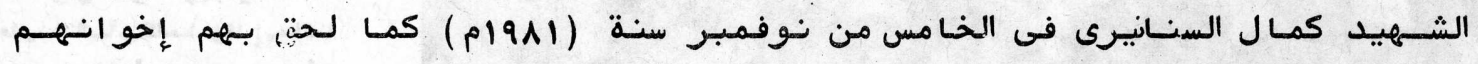

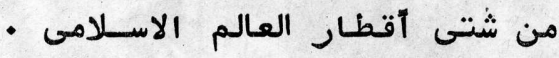

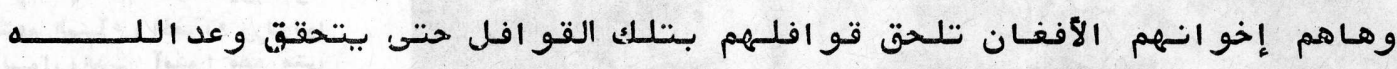

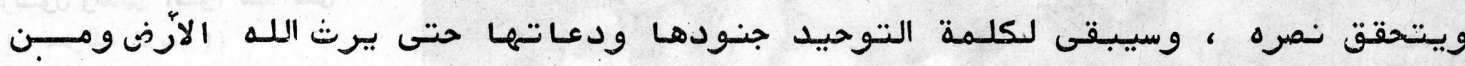
1 


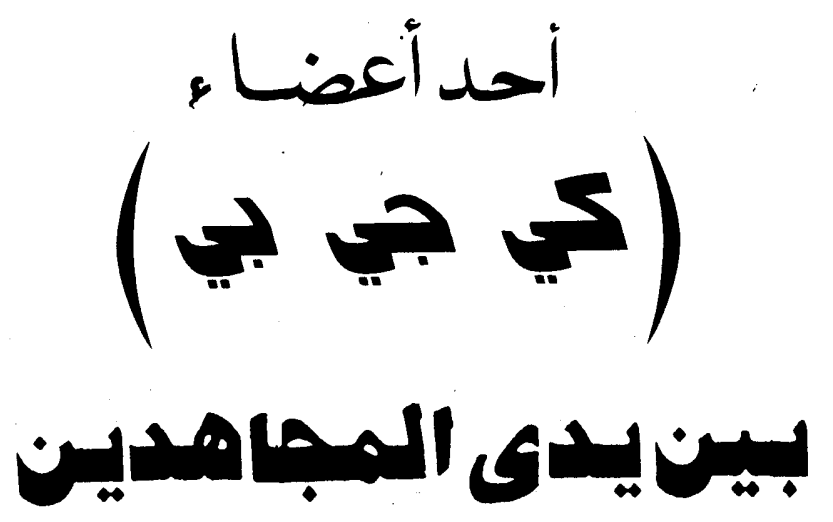

هن اير.ان بواسطة آلـة حساسة كـان يلـتقط

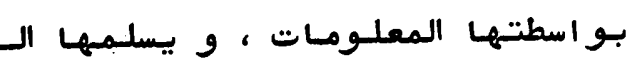

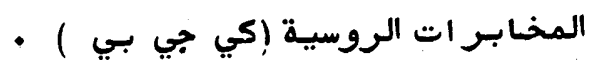

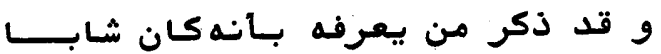

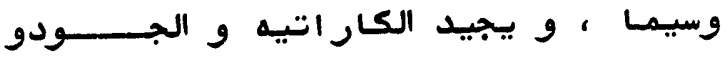

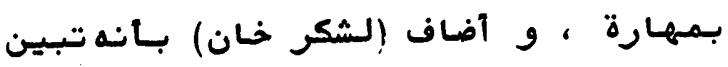

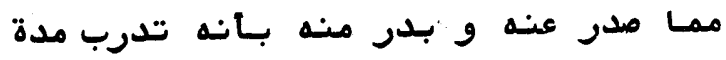

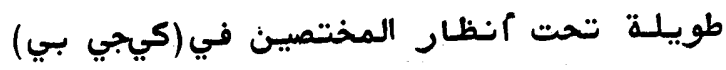

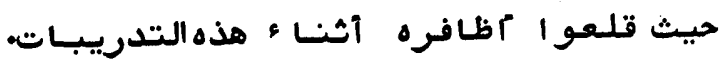

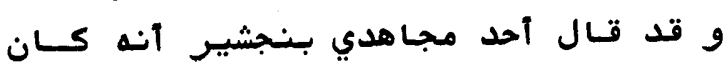

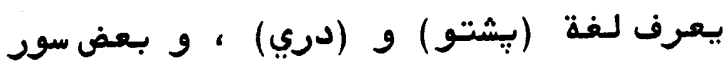

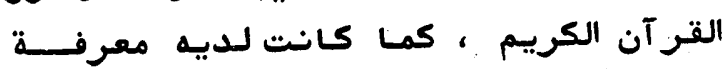

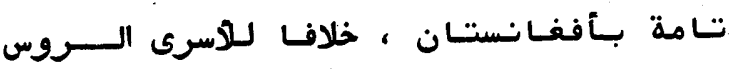

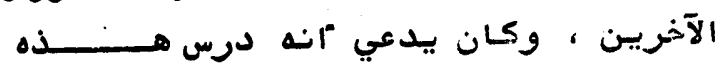

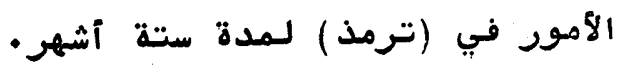
و ذكر المهندس ( عتيق الله ) مسمؤول

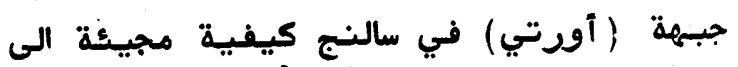

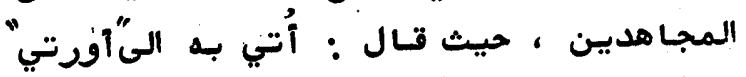

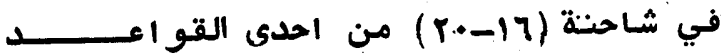

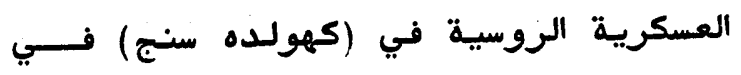

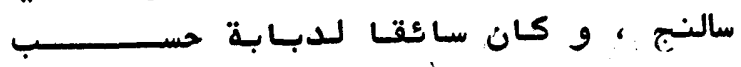

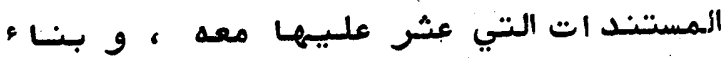

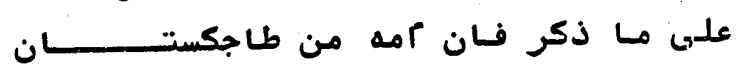

بـنـا \& على الانبـا \& الو اردة من المجاهدين

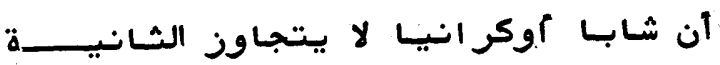

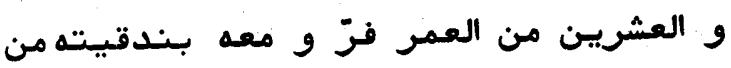

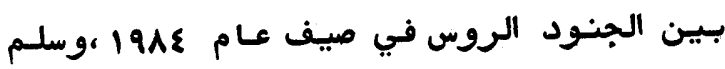

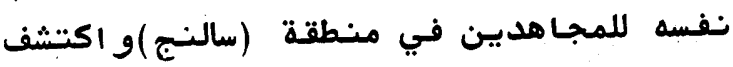

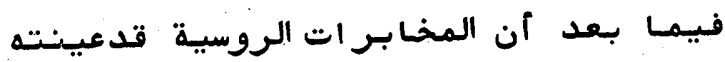

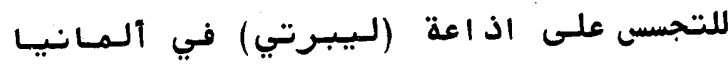
الغربية ، حيث بيملهـا عن طريق بـاكستـان.

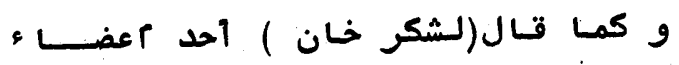

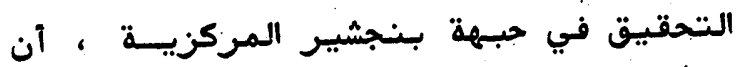

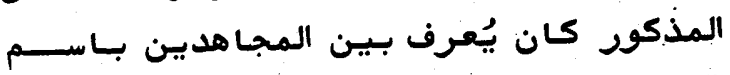

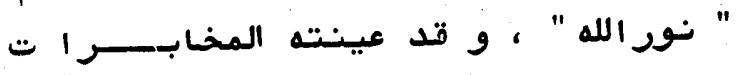

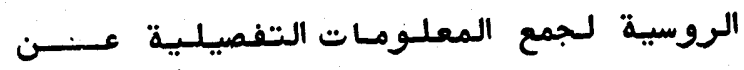

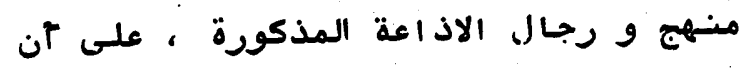

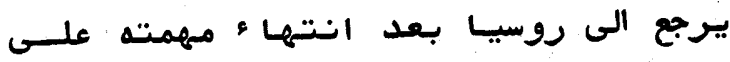

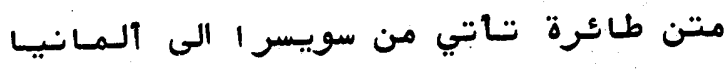

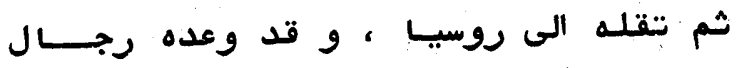

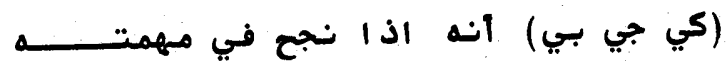

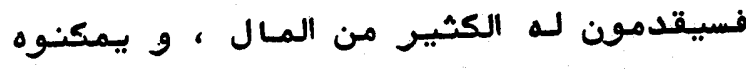

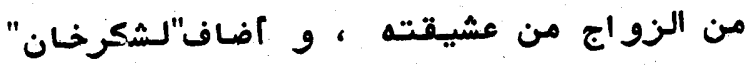

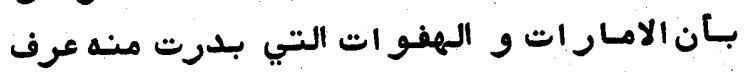

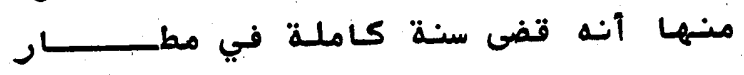

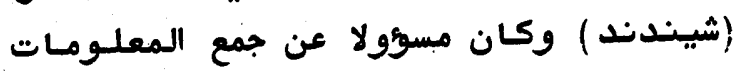


من قبـل المجـاهدين ، فـاطمـاًن اليه نـــــور

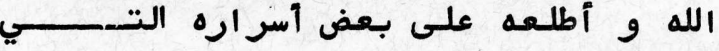

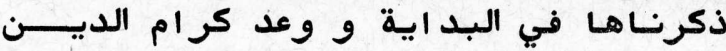
rنه سيزوجه من اخته النجمة الجميلة فـي روسيـ ان نجحسا في الفر ار من المجـاهديـن

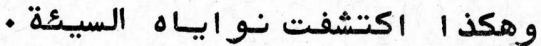

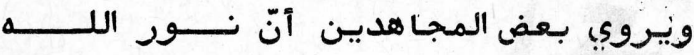

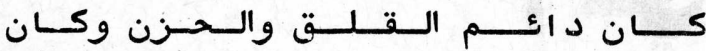

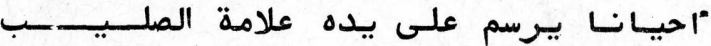

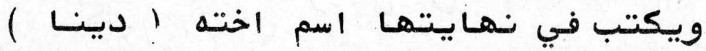

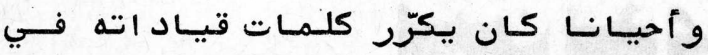

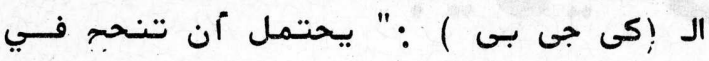

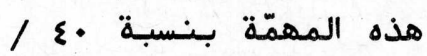
وجـاء في التقـريـر أنّ نـور الله كـان يــانم

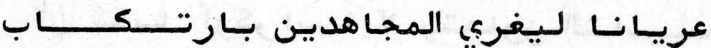

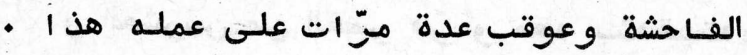

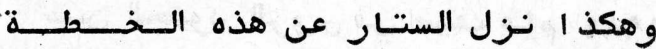

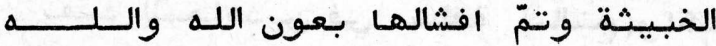
- حافظ جنده المخلصين

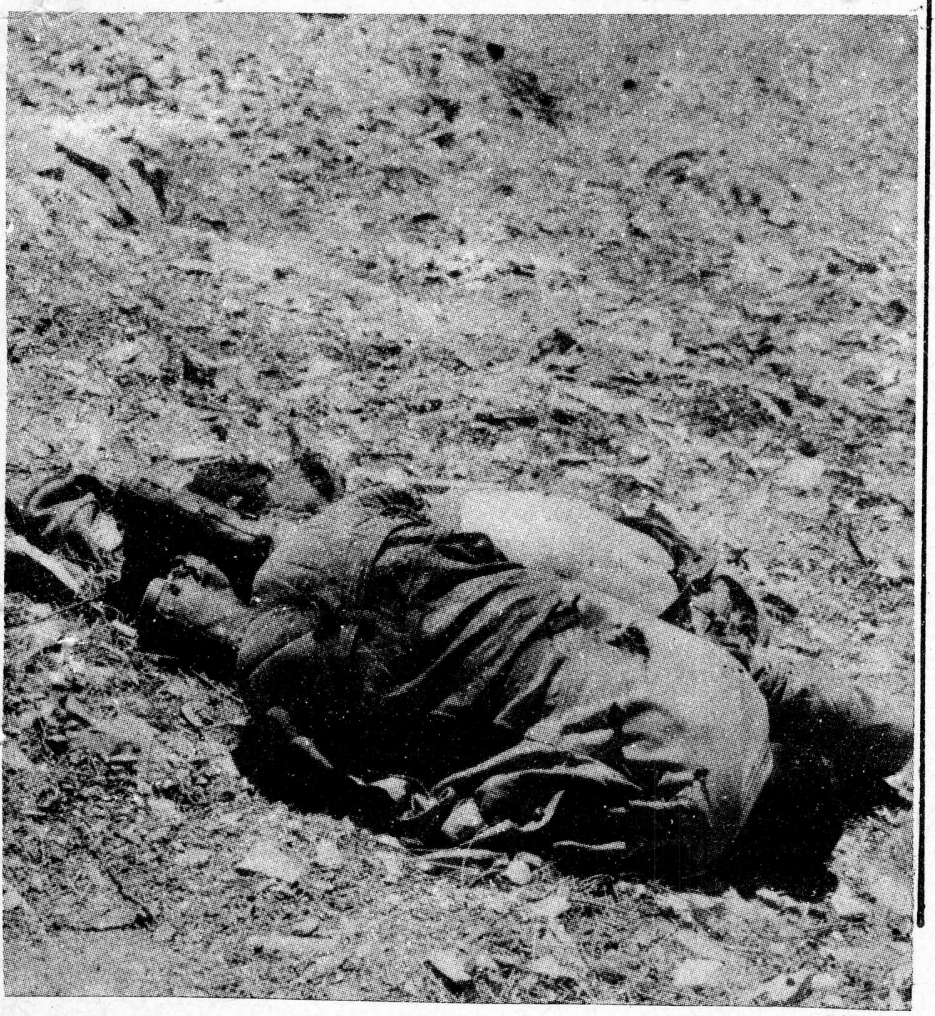

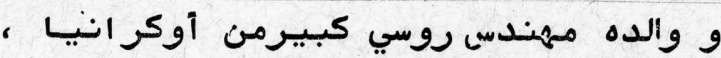

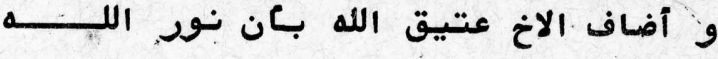

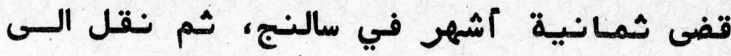
بـنشير حيث قضى مدة ثمـانية عشر شهــر

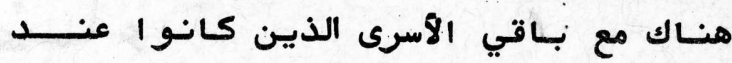

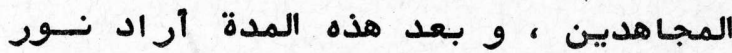

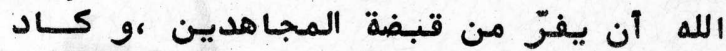

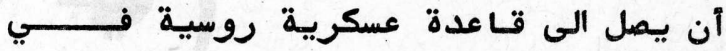

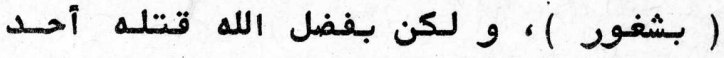

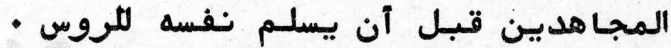

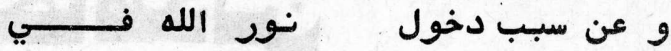

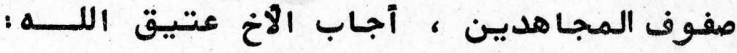

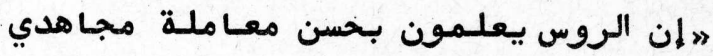

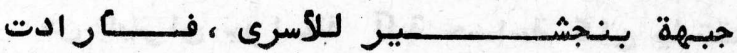

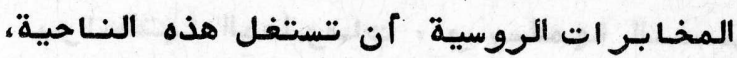

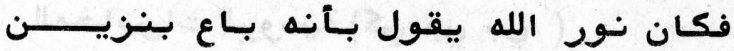

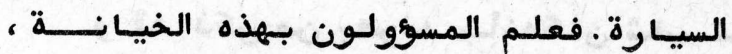

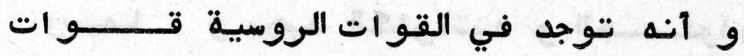

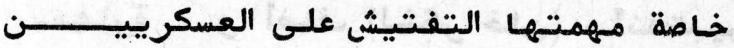

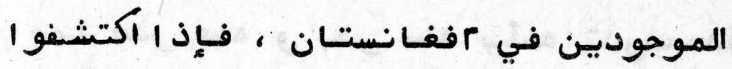

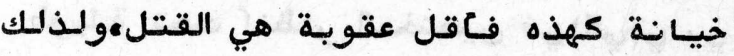

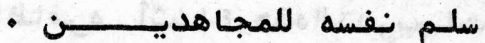

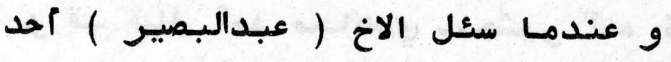

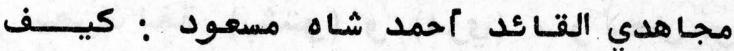

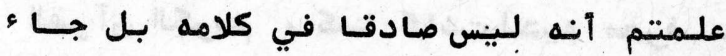
للتجسس ؟ أجـاب بأنه كان يمدر منه أعمال و تتمرفـات كانت تثير شكوكنا فيه ،و زاد من شكن هذ أ سرقته لـمسدس الاخغبدالصبور

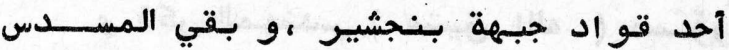

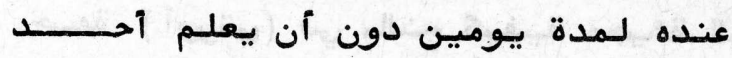

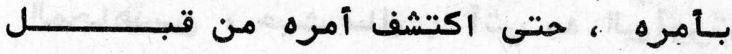

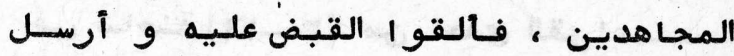

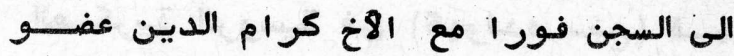
التحقبيق لدى المجاهدين ، و و الضاف

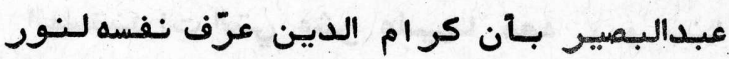

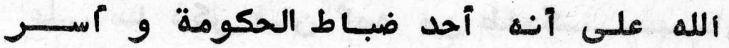

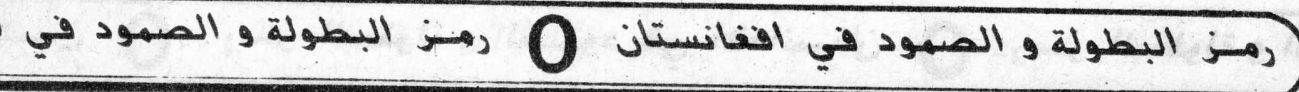




\section{افتتّاح \\ كي للمجاهدين بالشاروقة}

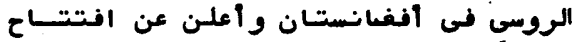

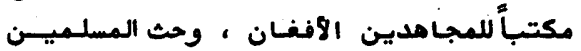

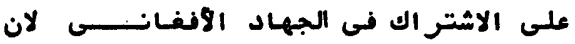

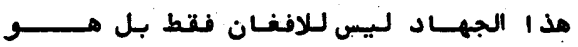

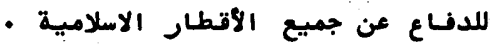

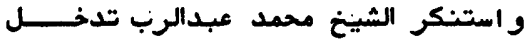
الجيش الاهر فى افغانستـان وايتلالفلسبطين

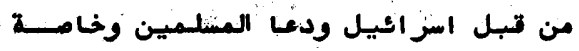

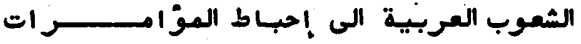

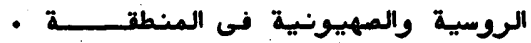

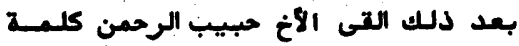
بالنيابة عن الاستاذ ربانى والمجامديسيسن

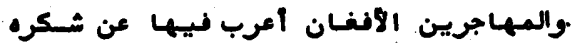

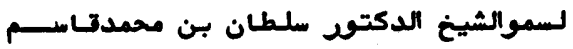

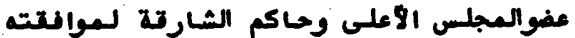

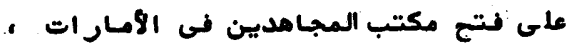

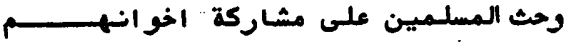

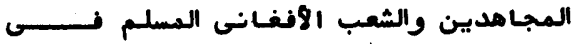

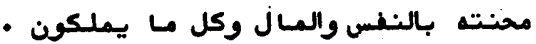

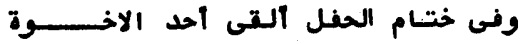

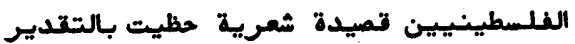

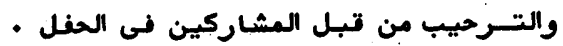

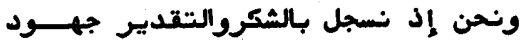

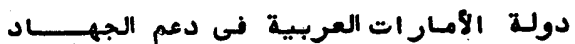

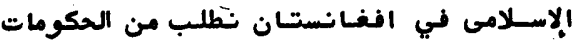

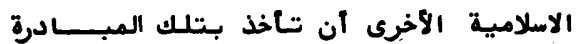

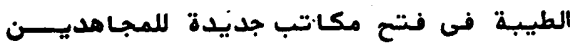

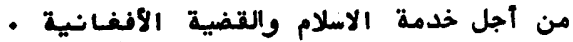
وعلى الاخوة الذين يرغبهن فى الاتعال بالمكتب يمكنهم التوجه إلى العنو انرئ في الإنى
والقت بدولة الامسار ات العربية المتحدة على لتع أول مكتب رسمى للجمعية الاسلامية

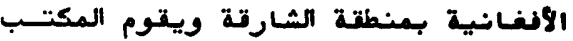

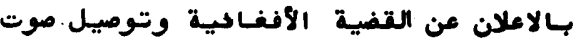

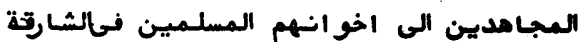

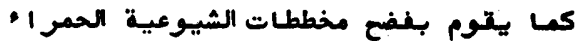

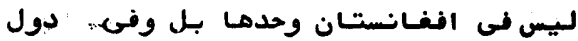

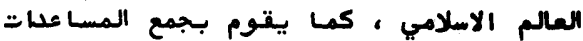

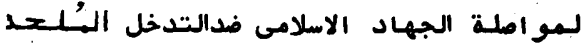

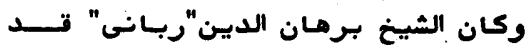
تـدم بهذا الطلب أثنـام جولته في في دول دول

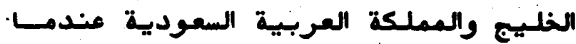

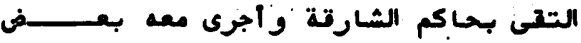

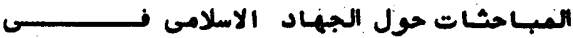
- الفانستان

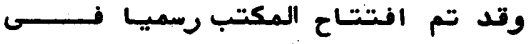

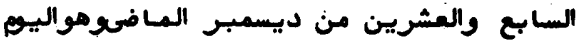

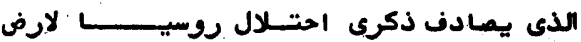

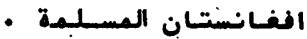

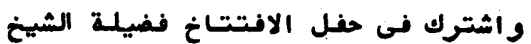

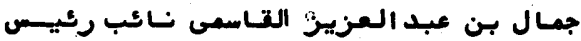
وزارة الشثقن الانسلامنية والاوقتاف والدعوة

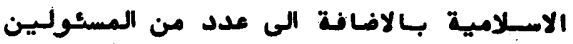

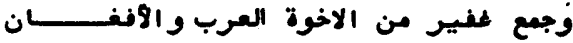

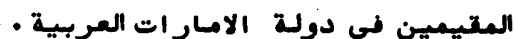

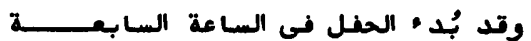
والنمف فى مسجد عمر بن الخطاب رضى اللهـ-

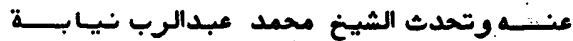

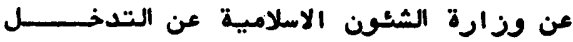

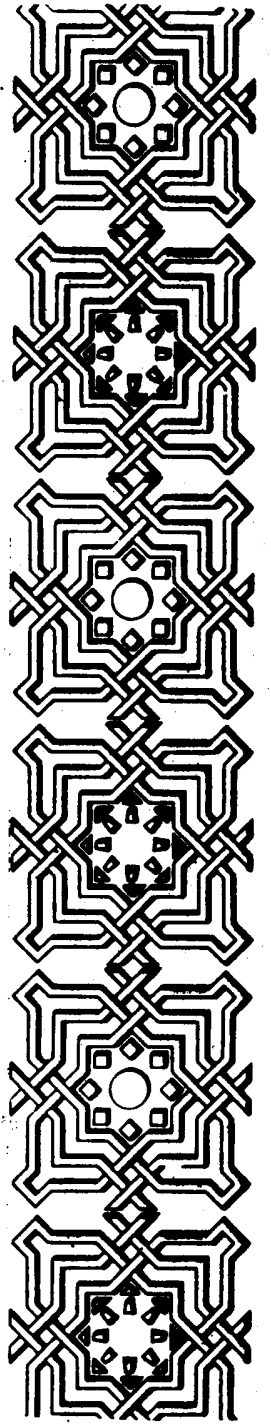

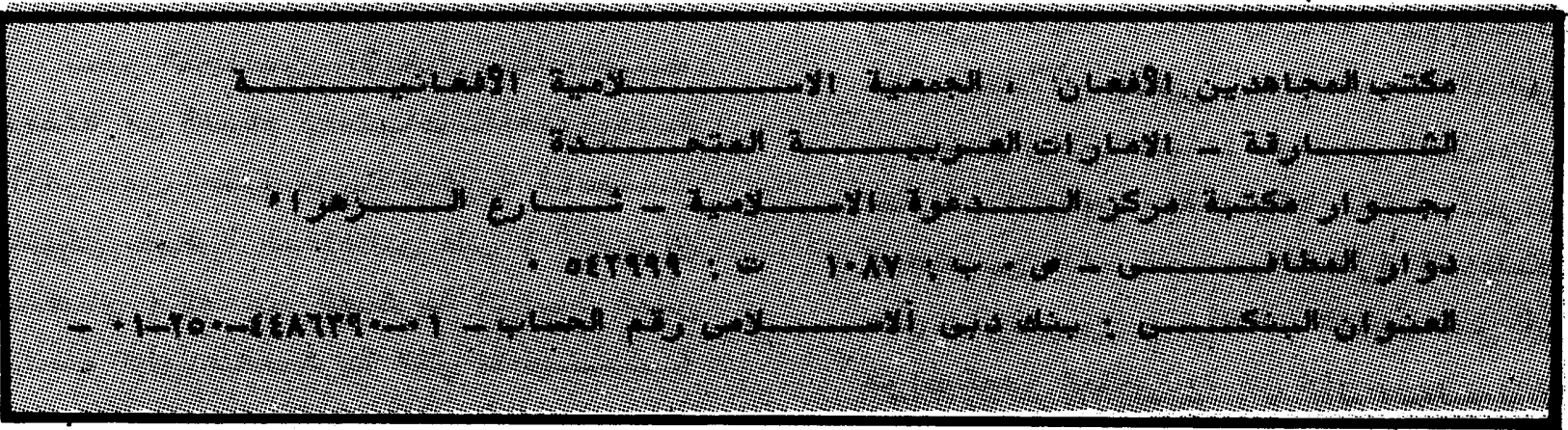




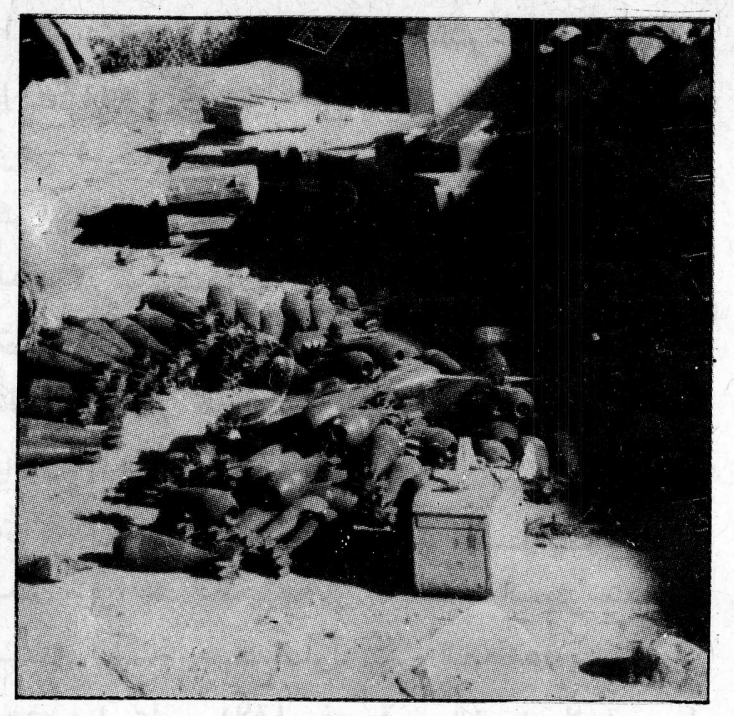

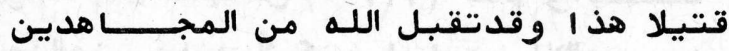
(I:) شهيد ا · وجرح (11) آخرين وعقبـ هذا الفتح الكبير تـابع المجاهدون هجومهيم البطولي بـتاريخ (9) من العقرب على لـو اء المستقر في (منجـان) منطقة (شهر ان) على

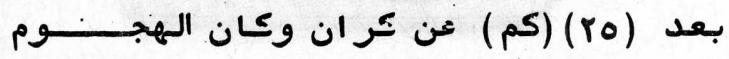

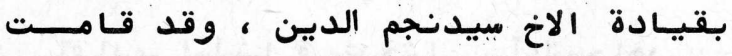
قوات العدو بـتهريب الفصيلـة الاولـوالثالـثة صوب زيبـاك و اشكـشم ، في حين أستســـلـم

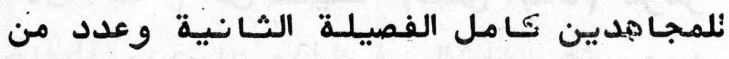

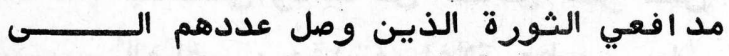

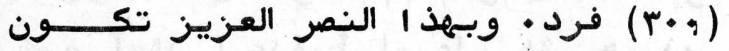
انمنسطقة محررة حتى نـاحية هضبة (توبنـانه)

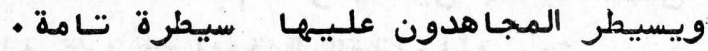

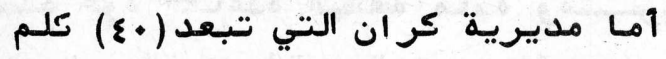

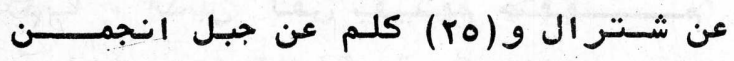

من انلـو اء النثالت وفصبيلة سار ندوى،وفصيلة استخببار إت عسكرية (خاد) وعددمنمد افعي

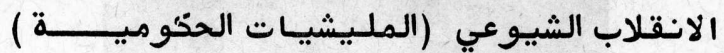

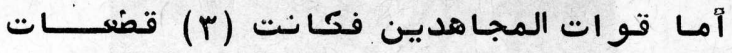
مركزية للمشاة ، قطلهتـان مركزيتـان مـــن رجـال المد افع ،مجموعـات للمفخـابـرةو الاستحكام م والدفاع الجوي ومركز نُمحة • كذلبك شاركت

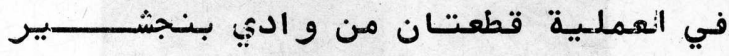

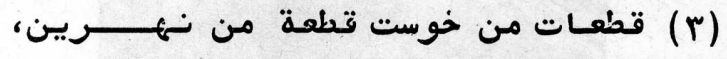

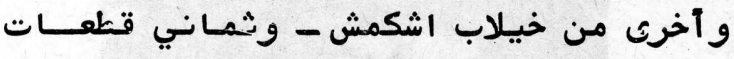

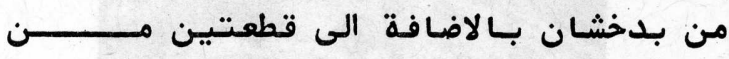
-

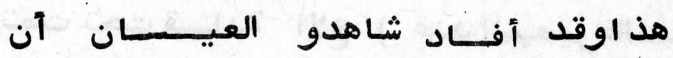

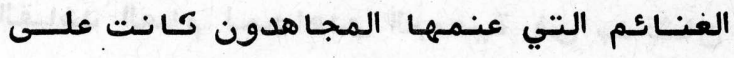
النحو النـاليب :

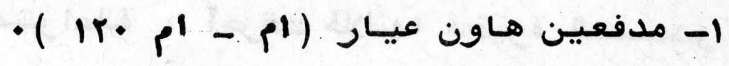

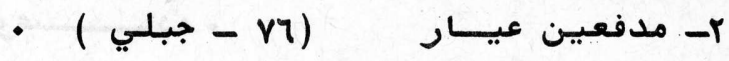

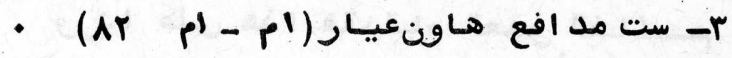

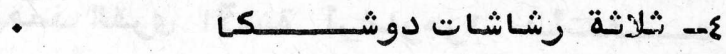

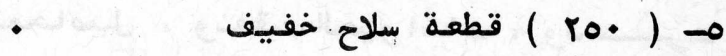

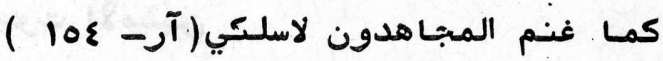
من نوع (بالمـا ) و (سبك) تـابع للاستخباز ات الفـيلة (خاد) وجهاز لاسلكي(آر -

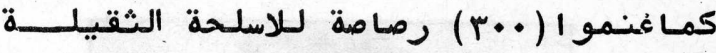
ومليون رماصة للاسلحة الخفيفة بـالاضافــة

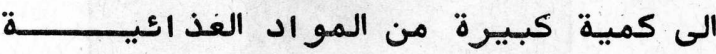

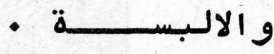

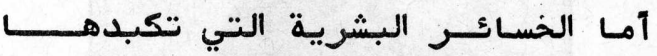

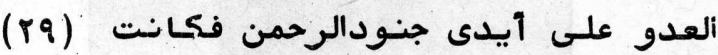

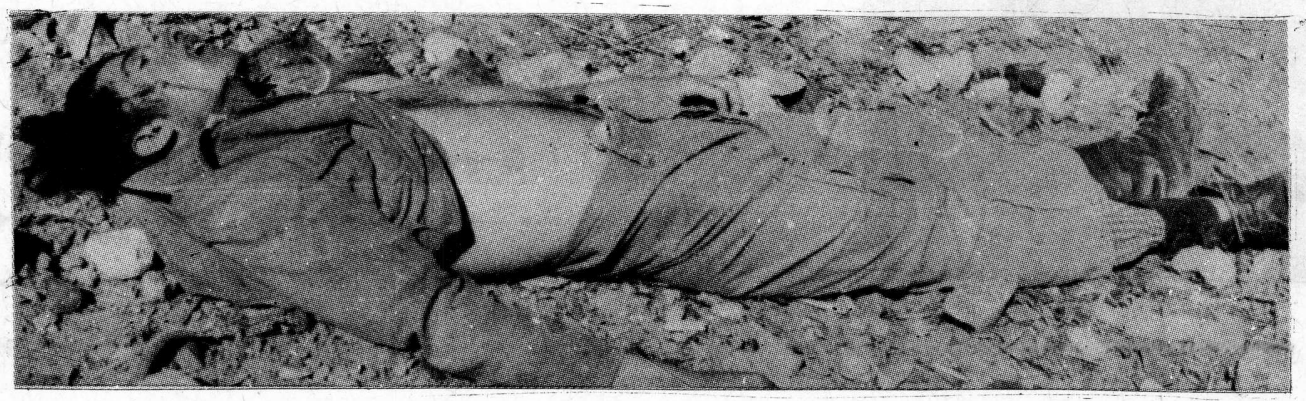

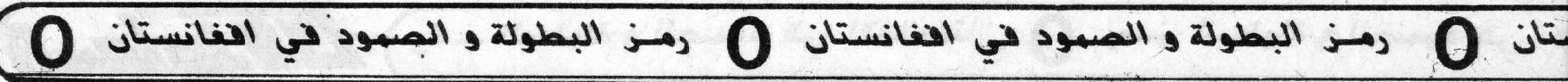




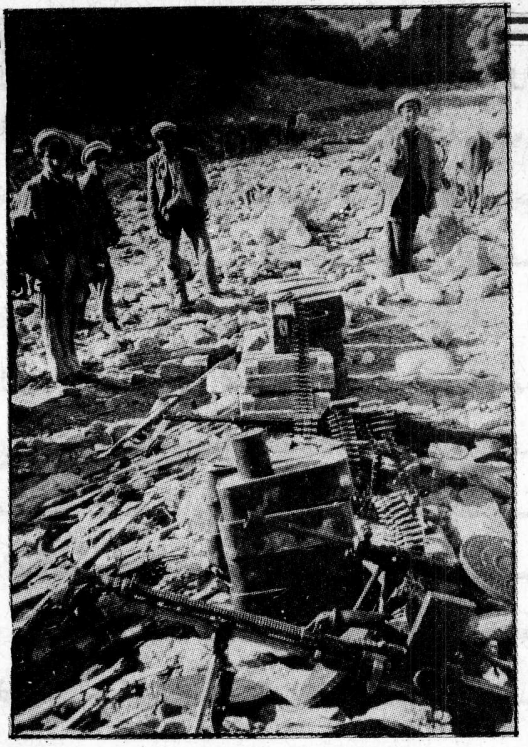

تمتت تحت قيـادة الاخ ( عبد الببصيرخالـد ) القـاعد العـام لـمجـاهدى الجمعية فـى بـدخشان

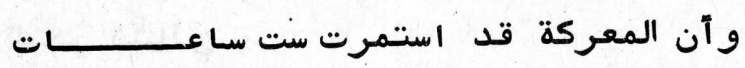

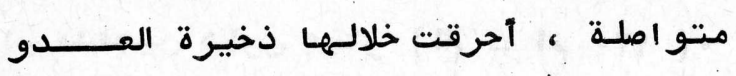

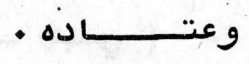

وردا على هذا فقدقـام العدو, الفـاشــم

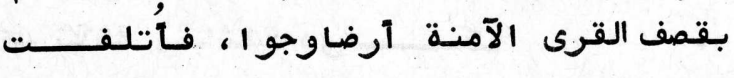

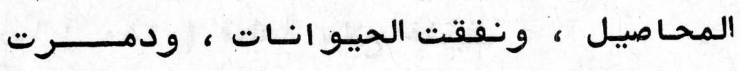

$$
\text { بيوت الآمنين }
$$

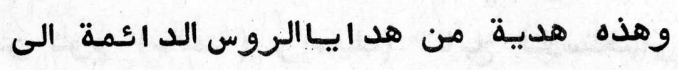
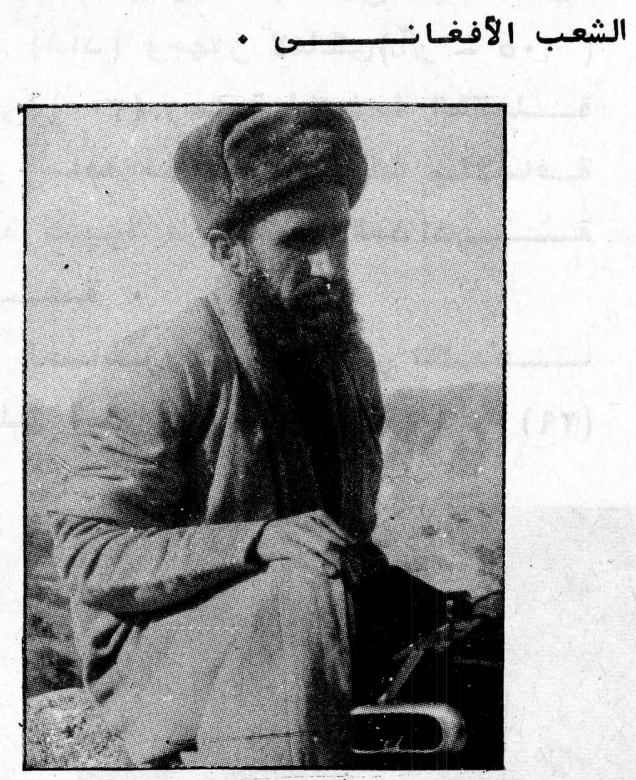

الشهيد .محمد انعـام احد شهد اء العملية

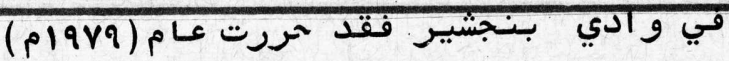

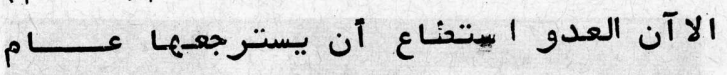

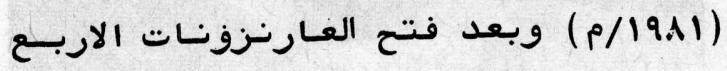

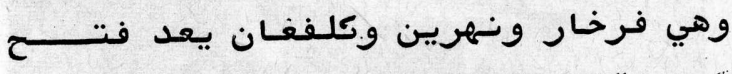

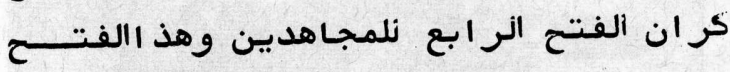

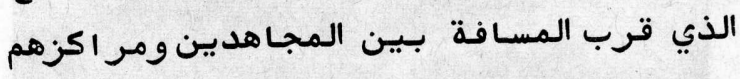

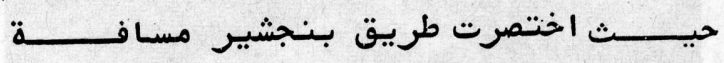
ثلاثة آيـام كما قرب طريق بدخشانأسابيع واصبح السمجـاهدون يقطعون مسـافــة (10) يـومـا

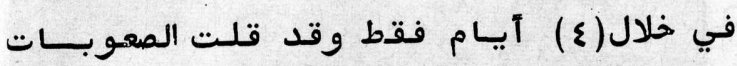

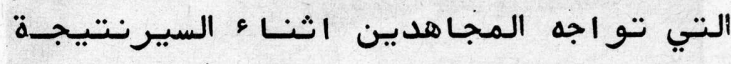

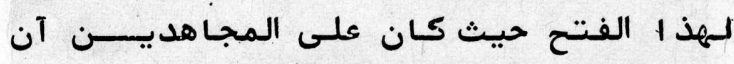

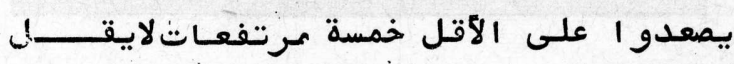

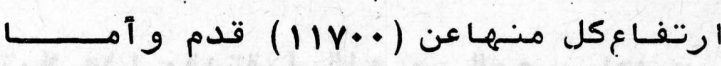
بعدالفتتح فـانه لايكون امسامهم الاالصعــــون

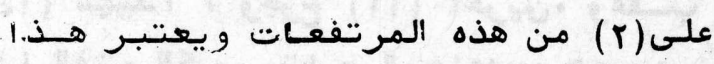
!لفتتح علامةو اضحة على هذه فشل مخططات العدو و

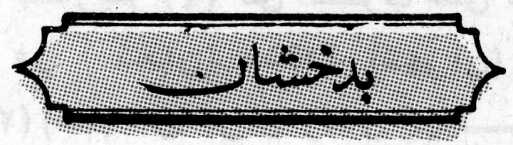

افـادمر اسلـن فى بدخشان بـأناتهجا هدين

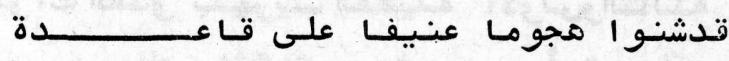

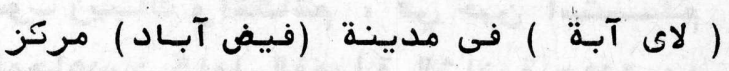

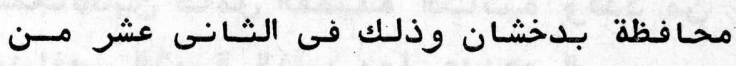

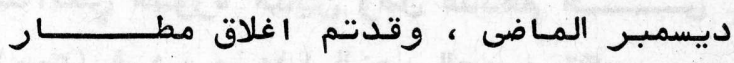

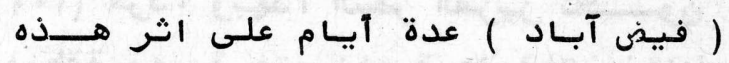

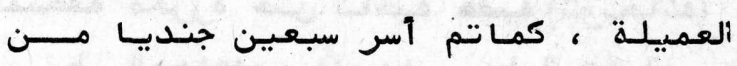

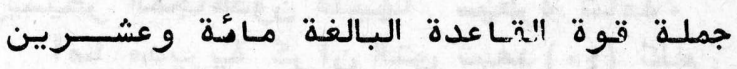

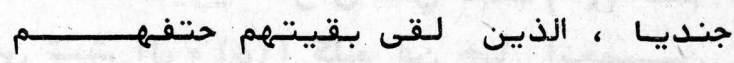

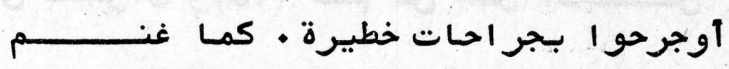
المجاهدون خمسة وستين قطعة سلاح مختلـفة احتة

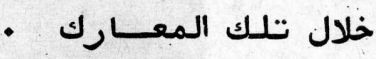

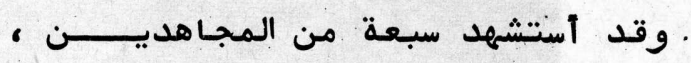

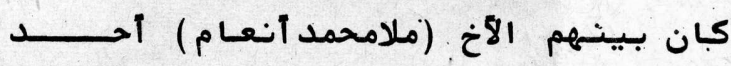

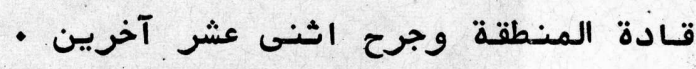

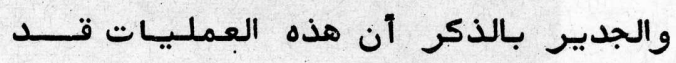


وكان لو اء (بوركة) يحتل مكانـة هـامة

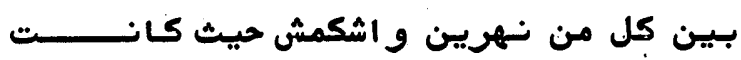

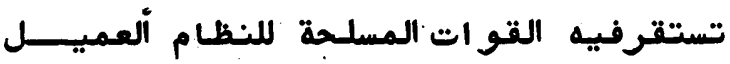

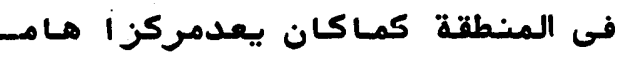

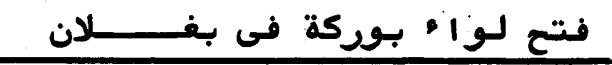

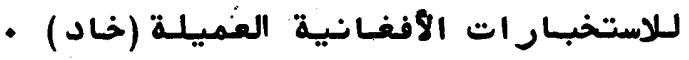

وبعد فتح هذالمركز تكون مساحةكبيرة

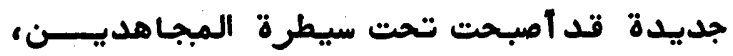

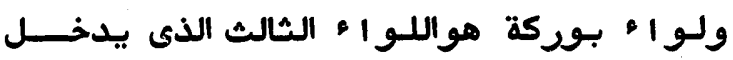

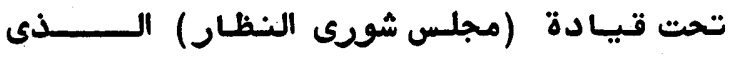

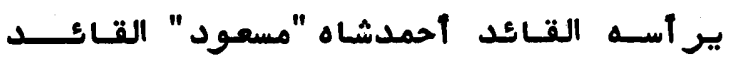

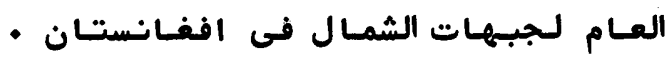

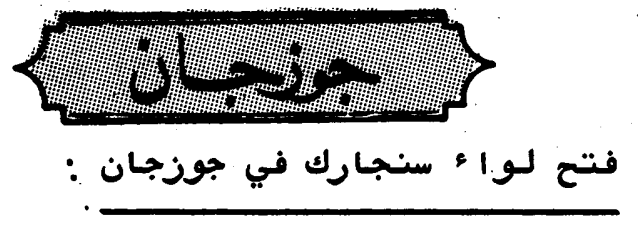

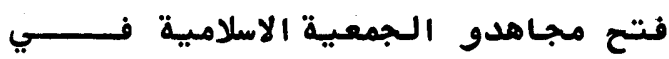

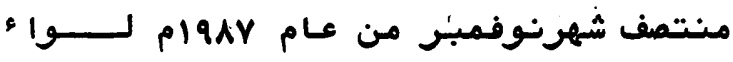

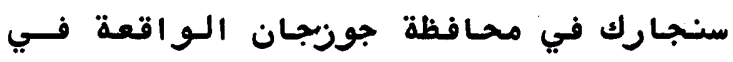

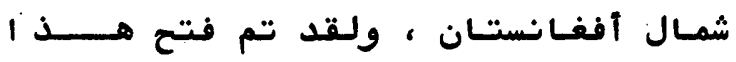

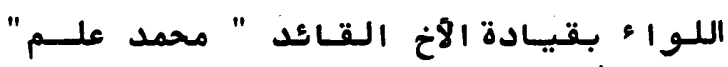

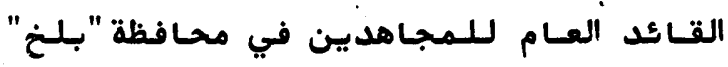

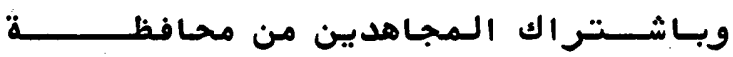

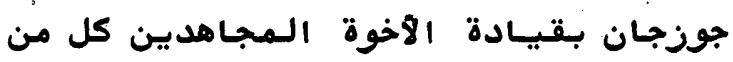

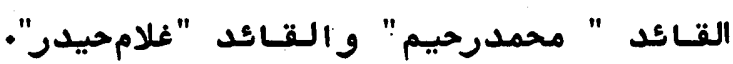

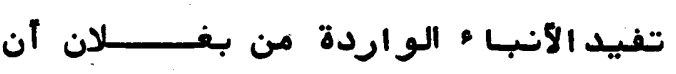

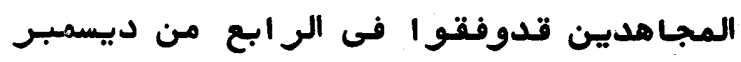

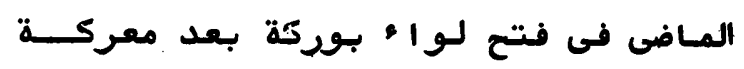

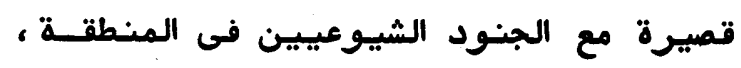

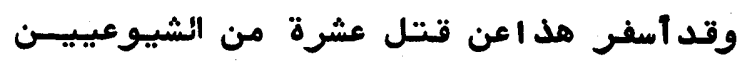

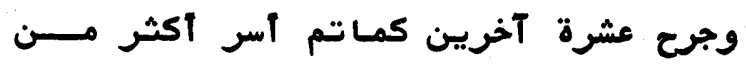
ماعة جندي وفابط عثرة آخرين اخرين

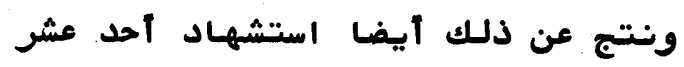

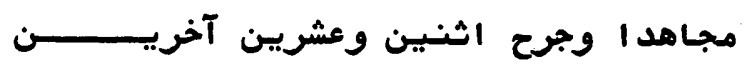

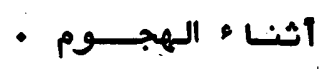

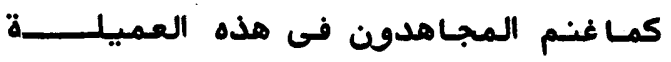

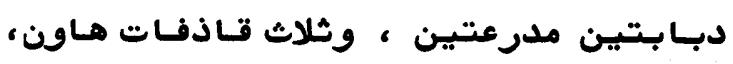

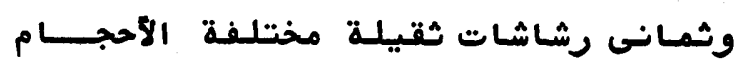

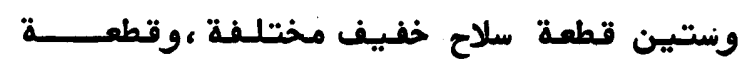

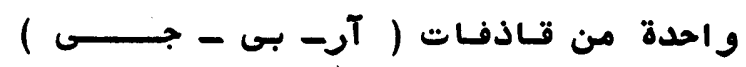

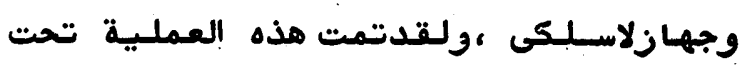

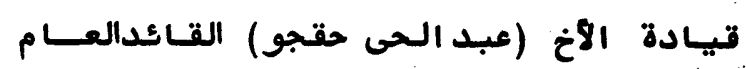

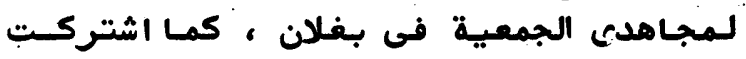

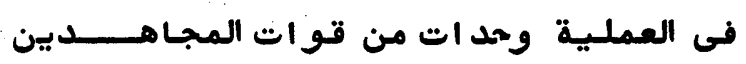

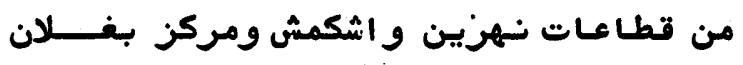

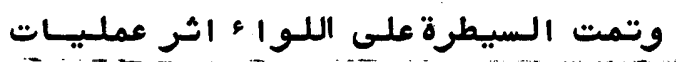

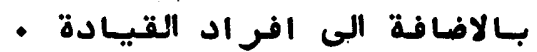

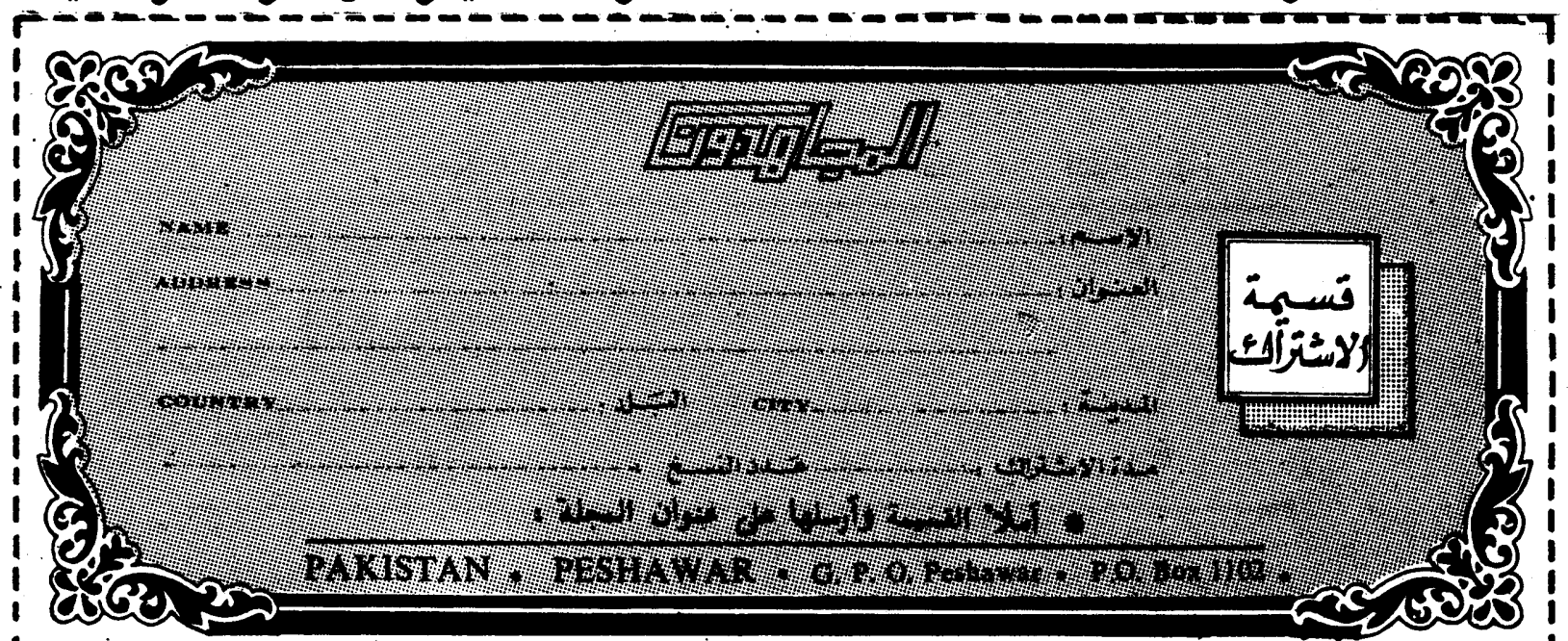

L-

ان O O رمبز البطولة و الصمود في الغانستان 0 رمسز البطولة و الصهود في الفانستان 0 


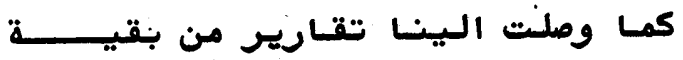

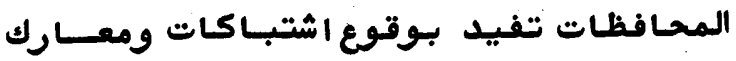
استغرقت أسبوعـ كاملا أبفرت عن مقتـــل

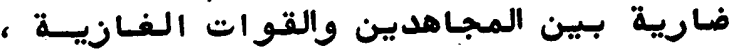

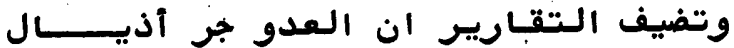

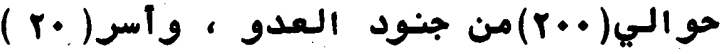

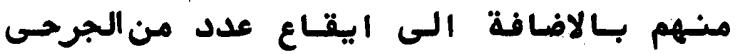

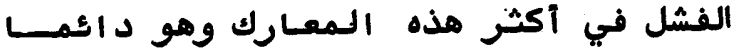
في موقع الدفـاع وان المجـاهدين هم الذيسرن

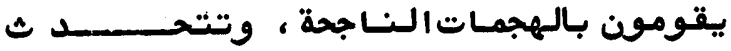

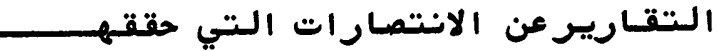

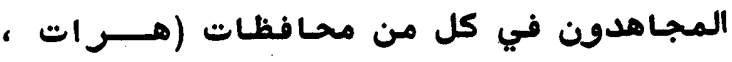

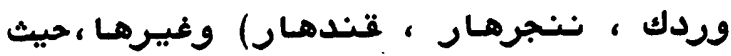

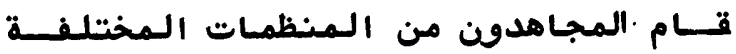

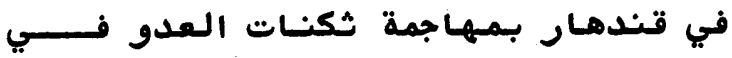

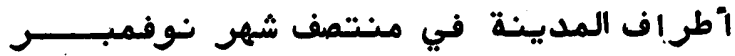

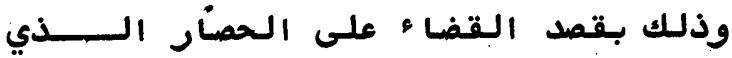

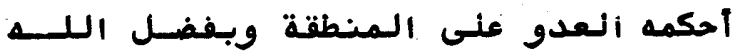

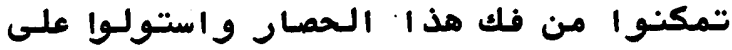

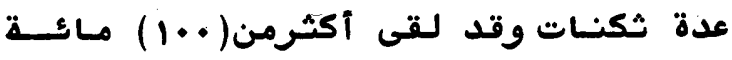
من جنود اللعدو مصرعهم خلال هذهالعمليات

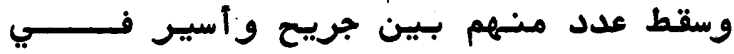

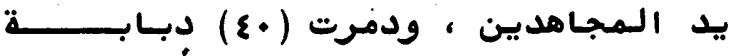

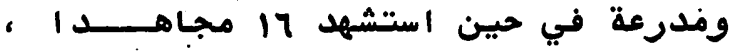

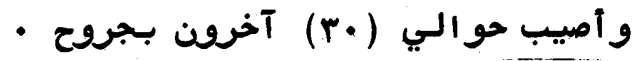

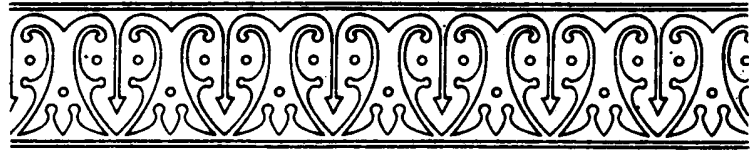

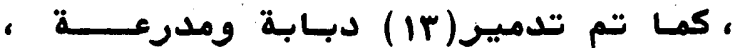
واسقـاط طاعرةة من طراز جيت ، وقد غنـــم

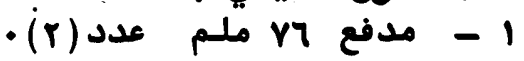

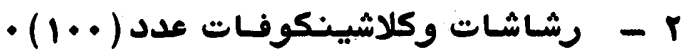

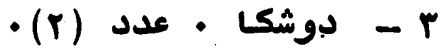

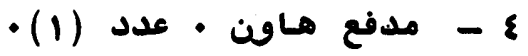

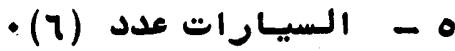

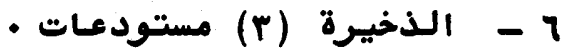

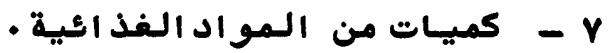
واستشهد خلال هذه اللمعركة شلاثة عشـــر

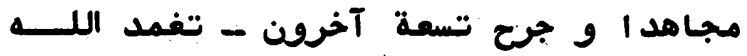

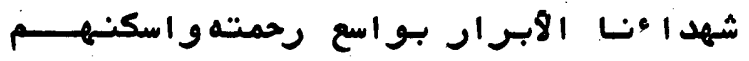
كمـا قـام ألمجـاهدون بعمليــات نـاجحسـة أخرى في محافظة جوزجان بقيـــــــادة (

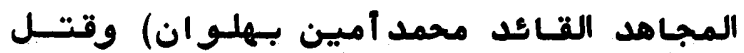

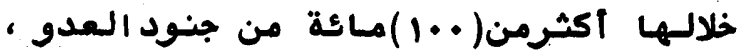
ودمروا (11) دبـابة ومدرعة في الـهجـوم

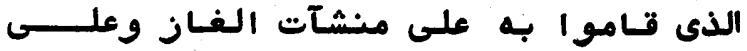
ثكنـات العـاملـين بـها في منطقة "جرقدوق مئه
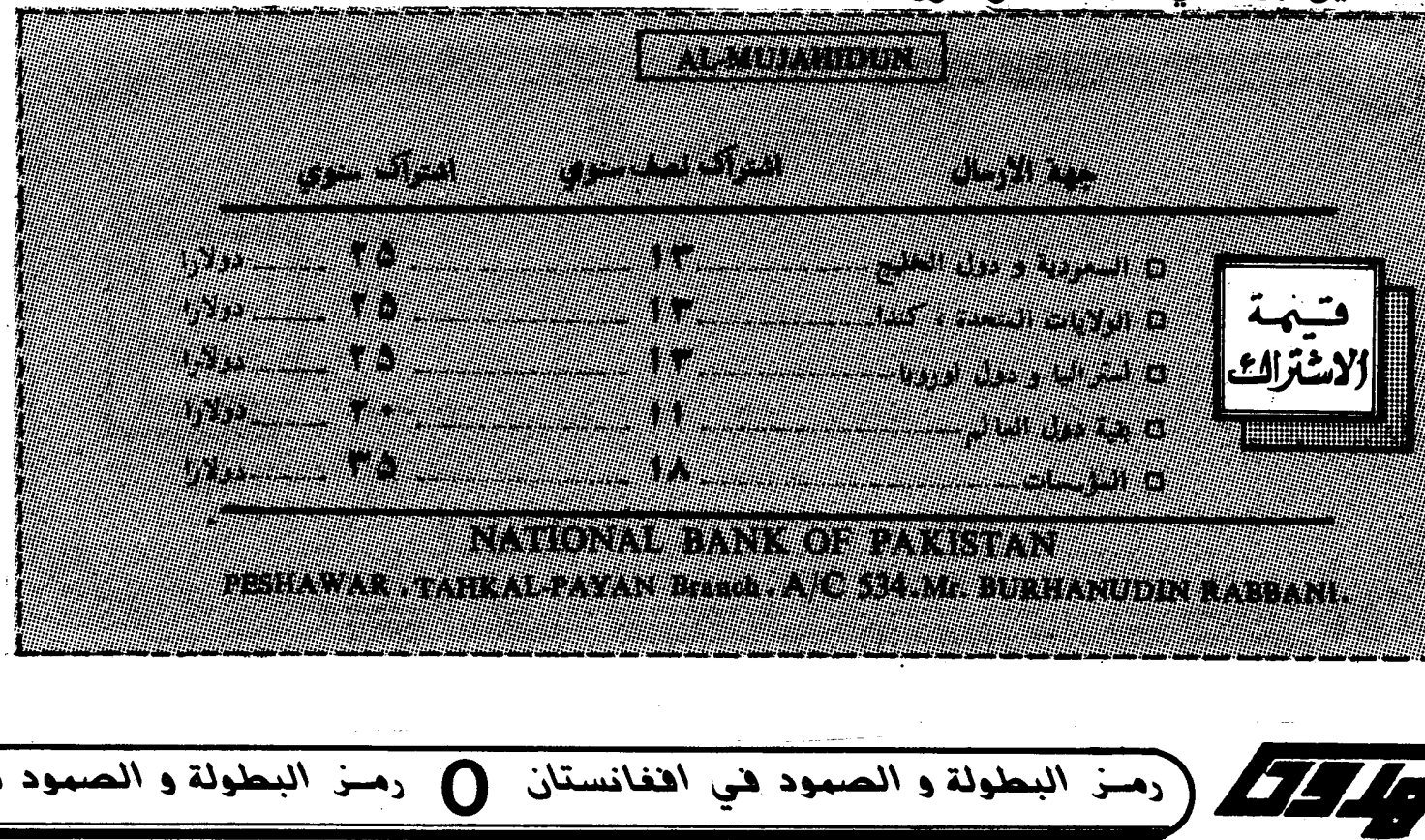

رمسز البطولة و المهود في النانستان 0 رمسز البطولة و المسود في افغا 
آهـا فى منـاطق ( تـاو اخ وعنـابةومزاج)

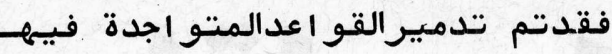

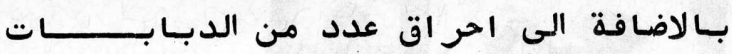

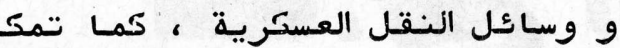
المجاهدون من تـمير مستشفى ومركز تـابع

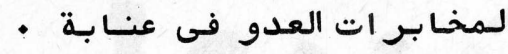
كمـاشوهدت أعمدة الدخان وهى تتتصاعـد فى منـاطنق ( رحمـان خيل وبهـارك ) • وقــد

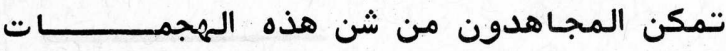
والفتتوحات - بـتوفيق من الله - رغم حقول

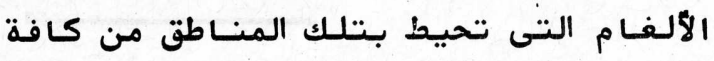

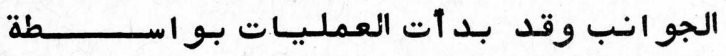

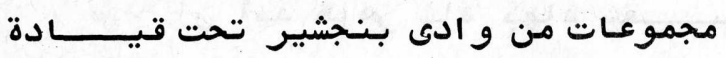
الاخ المحقق محمودخان ، وكسان هدفـها الاول

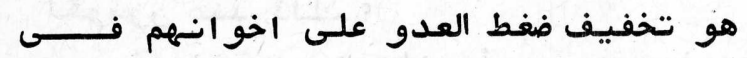

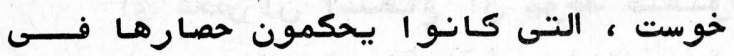

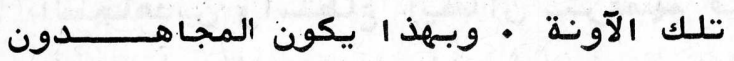

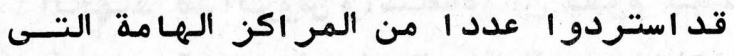

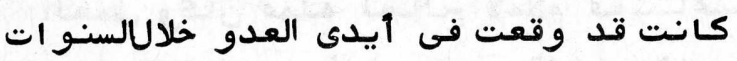

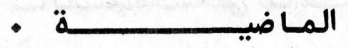

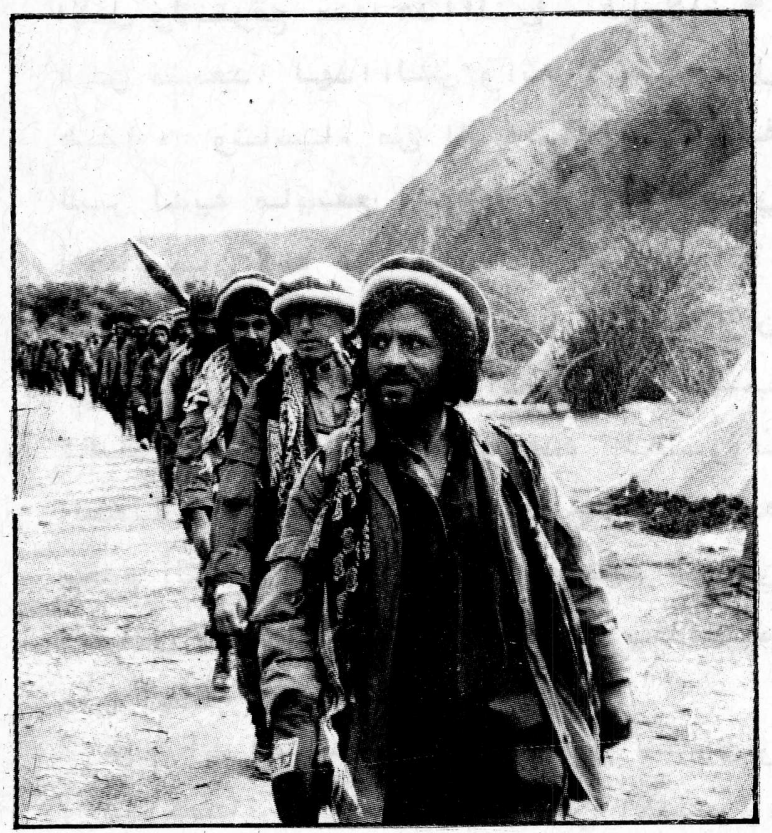

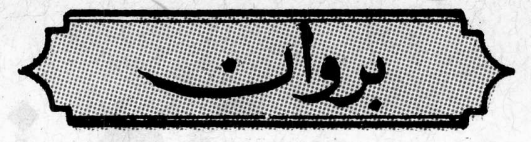

فتحلو اء ( شابه ) فى بـنشير

اختتم المجـاعدون العـام الثامن لنتدخـل

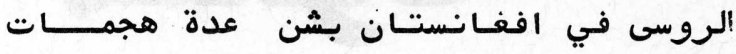

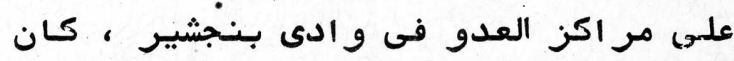

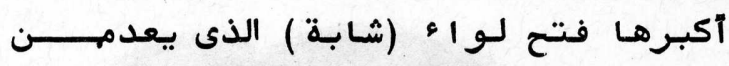

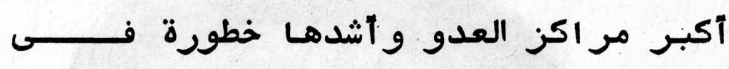

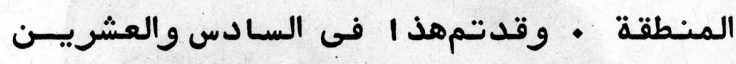

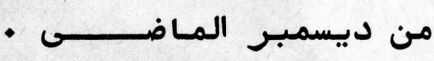

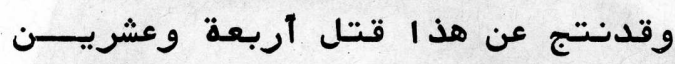
جنديـا للعدو،وآسرمـاعة وثلاثة عشر فذر آخرين

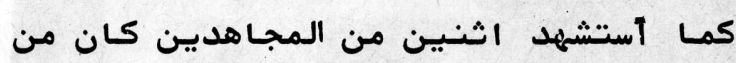

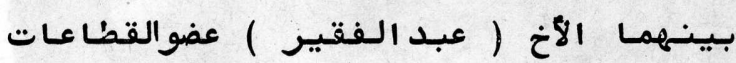

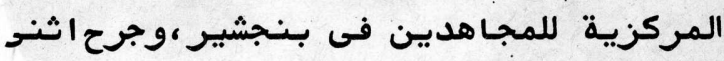

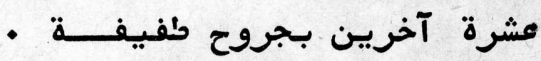

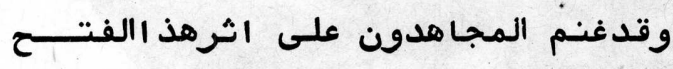

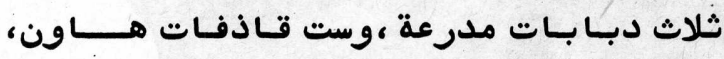

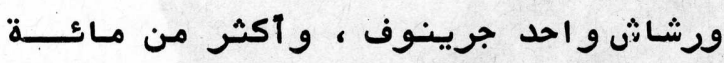

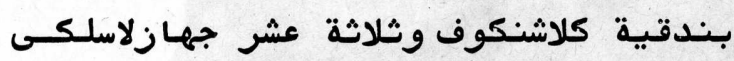

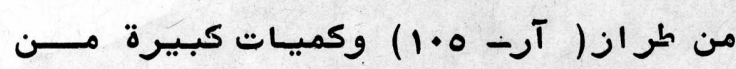
من العتـاد و الاثناث

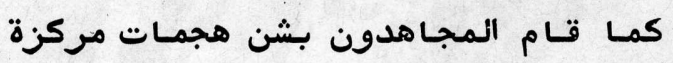

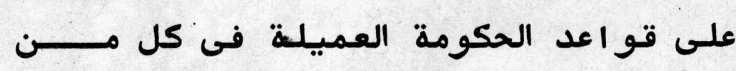

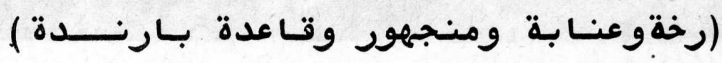

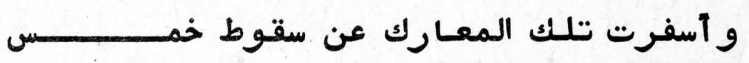

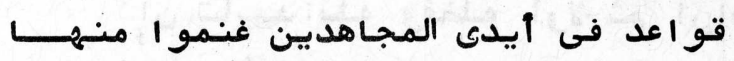
رشاشن و احدبيكه ، و واثنين وشلاثين بـدوقية

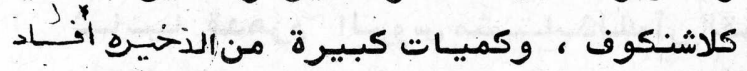

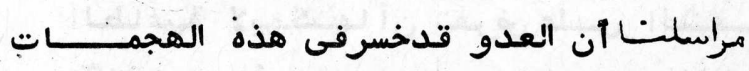

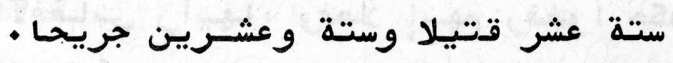

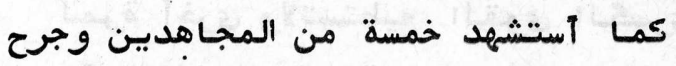
• ثمانية آخرون المنتمعن

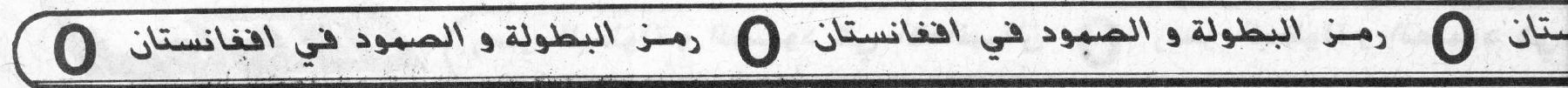




\section{القا. مع اسدبنجشير \\ أحمدشاه"هسمود"}

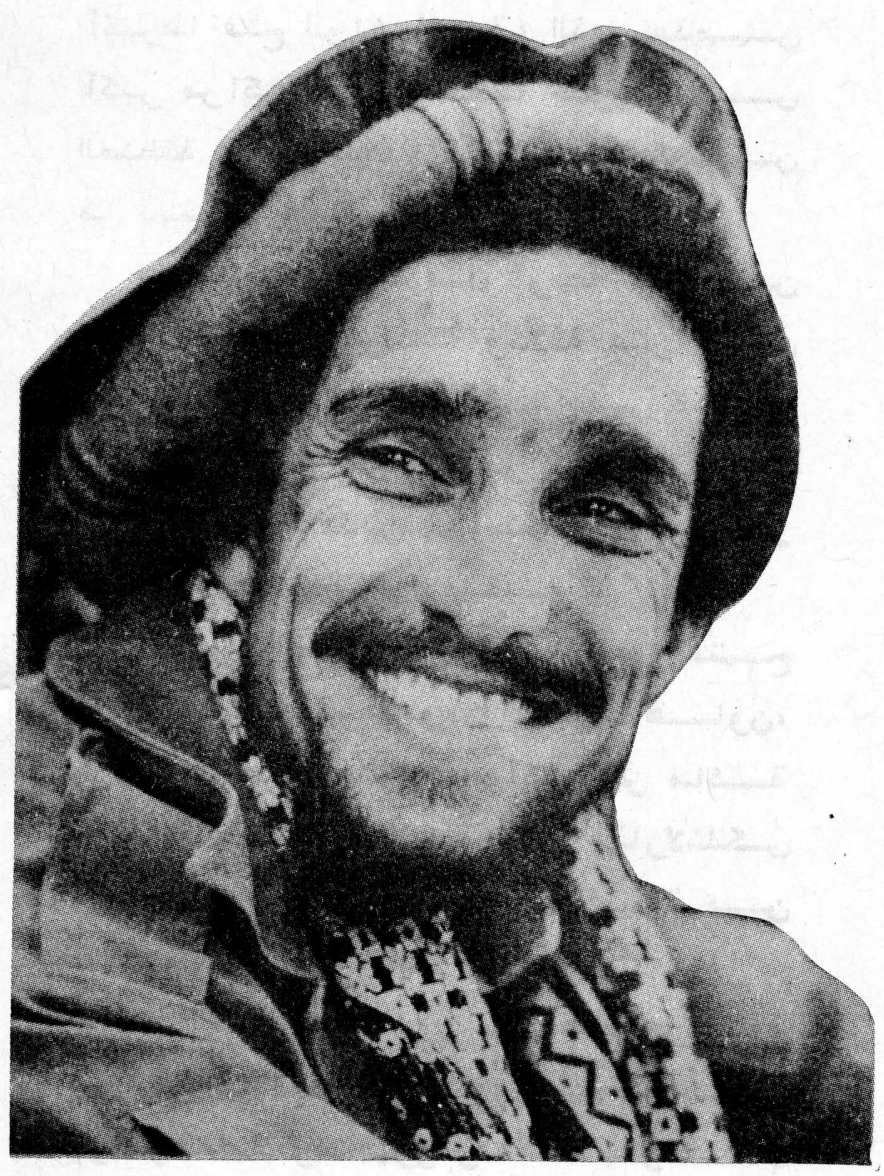

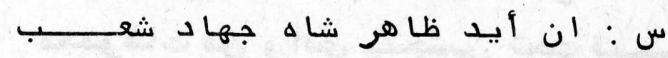

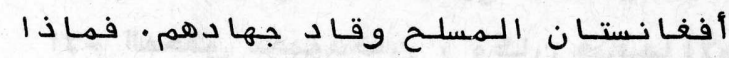

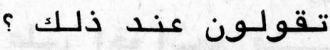

أي شخص ان استطـاع أن يـوحد مـفــوف

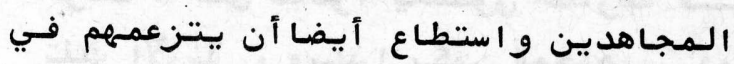

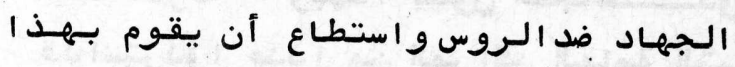

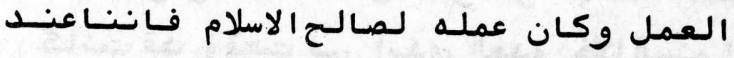

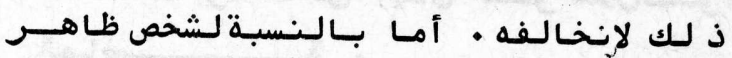

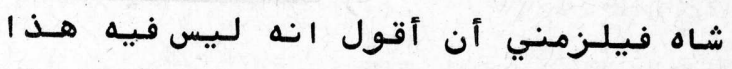

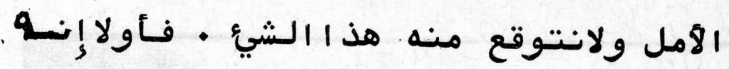

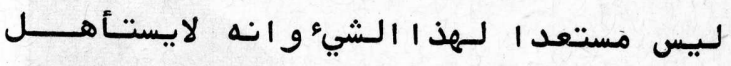

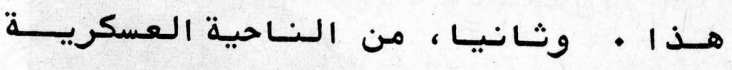

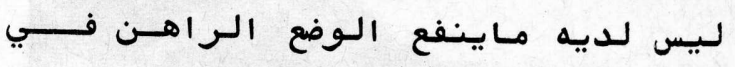

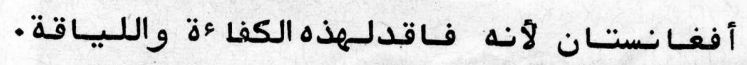

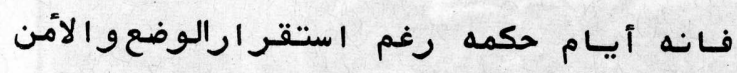

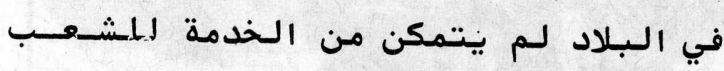

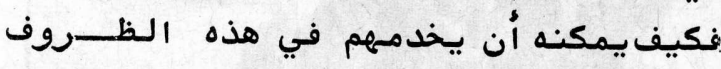

إن تـأيبـدالـله وفضله أولا ثم اررادة

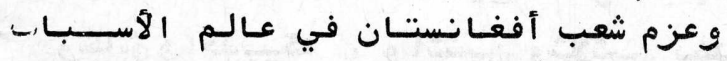

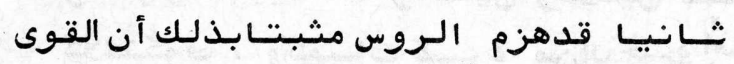

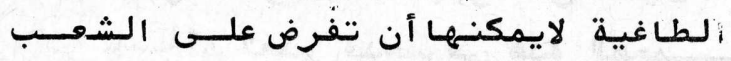

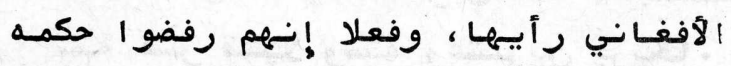

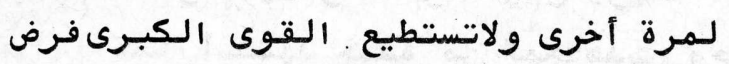

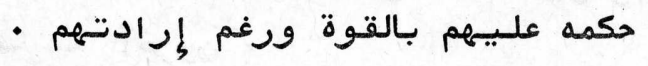

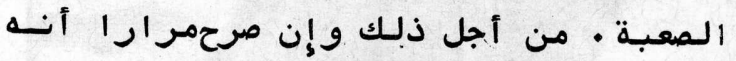

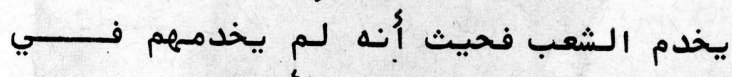

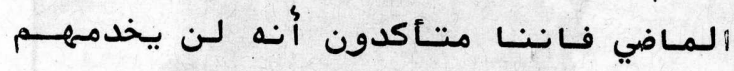

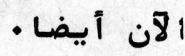

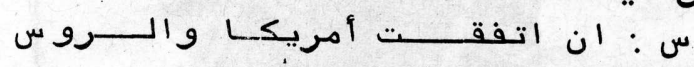

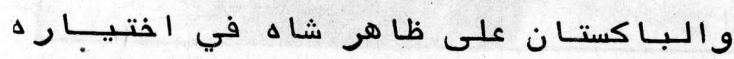

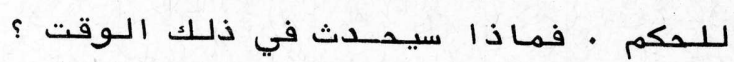

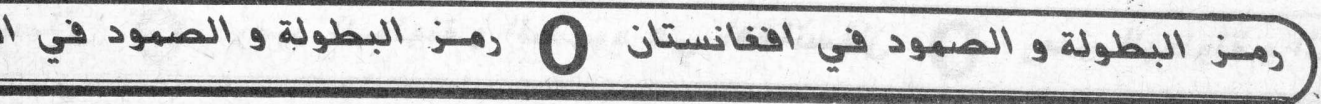


مخافظات لـيس أمرا سهلا فـانالـوحدة بيسن خمسة محافظات تحت قيبادة و احدةو أمرواحد

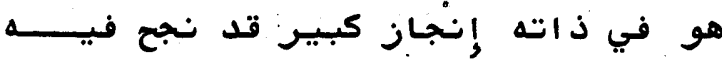
السورى في بداية انطلاقته الأولى • وفي فئي

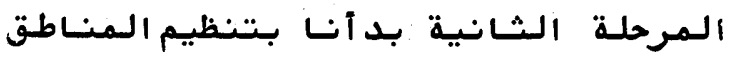

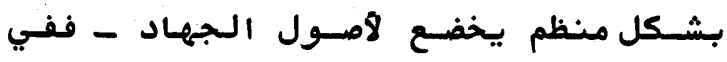

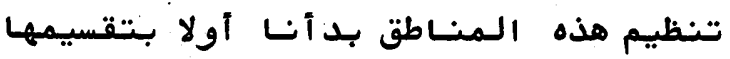

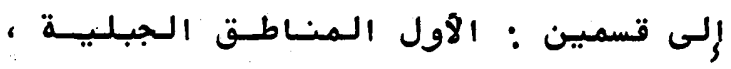
والـثاني الـمنـاطق الصحر اوية • لـقدتمكنت الصن

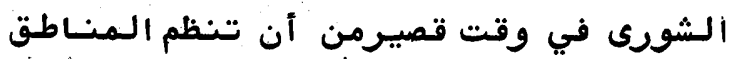

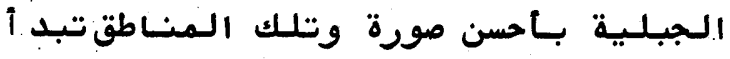

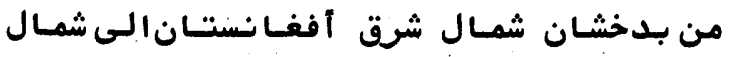

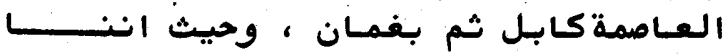

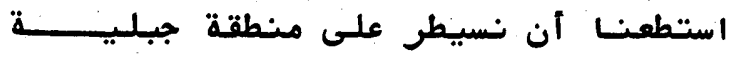

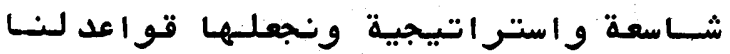

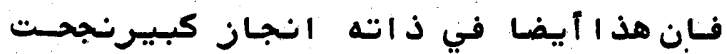

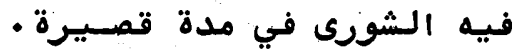

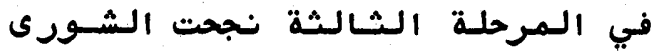
ثي محاولاتها توحيد مفوف المجاهدين مسن التنظيمسات الاخرى غير الحزب الاسـلامي وأن

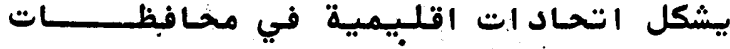
- تخار - قندوز وبفلان بيسـن الـمنظمات

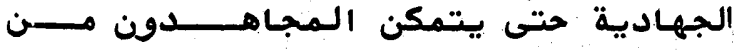

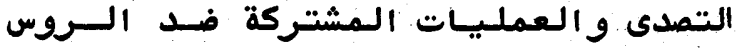
في مسف واحد وكلمة وقيـادة واحدة الأمسر الذي لانظير لـه في تـاريخ جهادنـابـالـماضي.

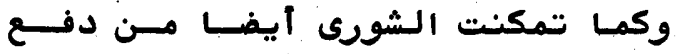

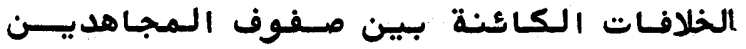

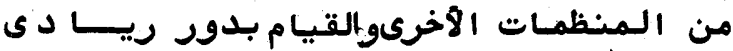

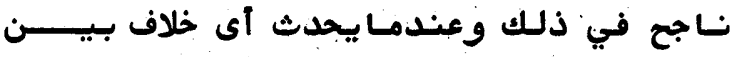

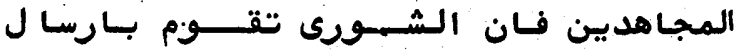

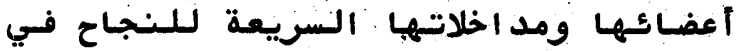

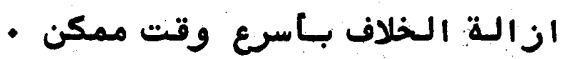

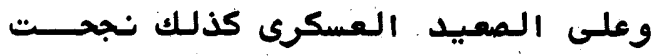

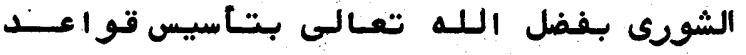

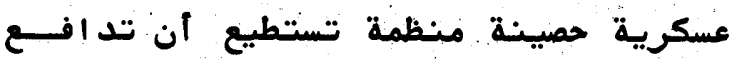

س : أعرب بعض السيـاسيهن عنعقيدتهم

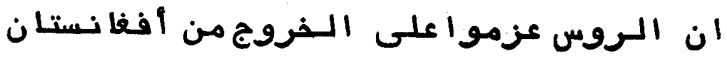

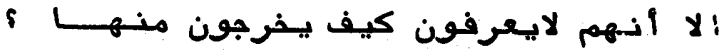

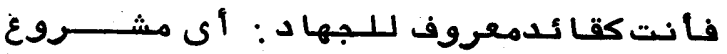
تـقترحه حتى يتـمكن بـ اللروس من الـخروج

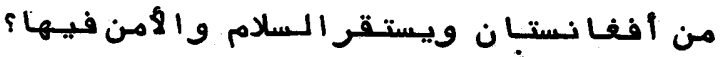

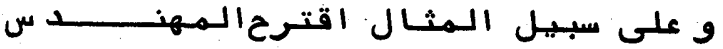
مكمتيـار وجيلاني مشروع الانتـفابـات العامة

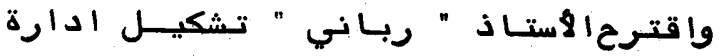

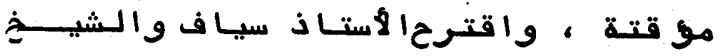

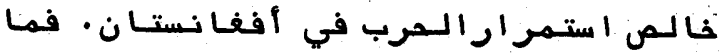

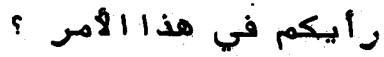
أن اعتقد أن جهبادنـ لـم يصل إلـى إنى مرحلة الـنضج ، انــا نجاهدمنأجل تحريز

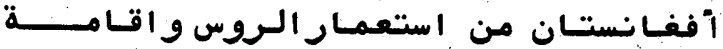

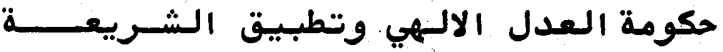

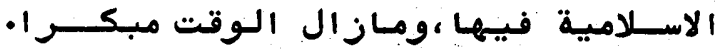

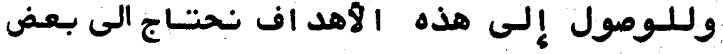

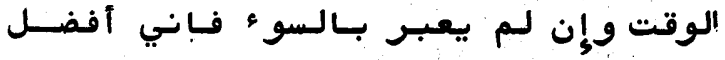

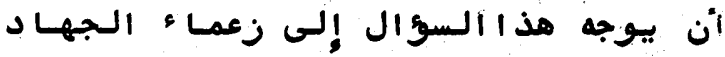
اذ لـيس لدي مشروع مرسوم في هذا ألامستر

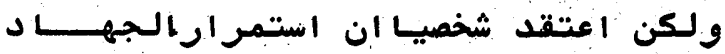

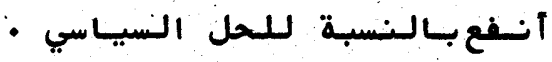
س : أود ان أسمع منكم كرئيس شورى

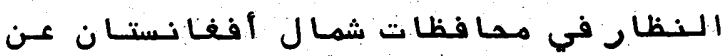

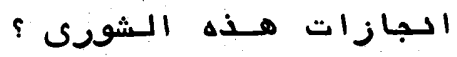

من انجازات الـشورى في بدابية الأمسر

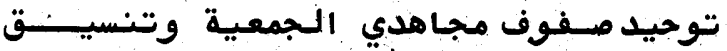
الا مور إلجهادية فيمبا بينهم إذ لـم يكن موجود ا بـالمـاضي ، فتمكنبت الشورى بفضل اللهد من إيجاد مذإالتنسيق وتجميع الاتخوة كيلهم حول مركزو احد وقيبادةواحدة • ومسن ألجدير بـالذكران تشكيل مثل هذه الشـورى مدرى

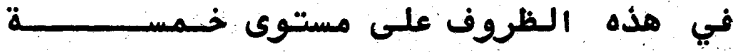



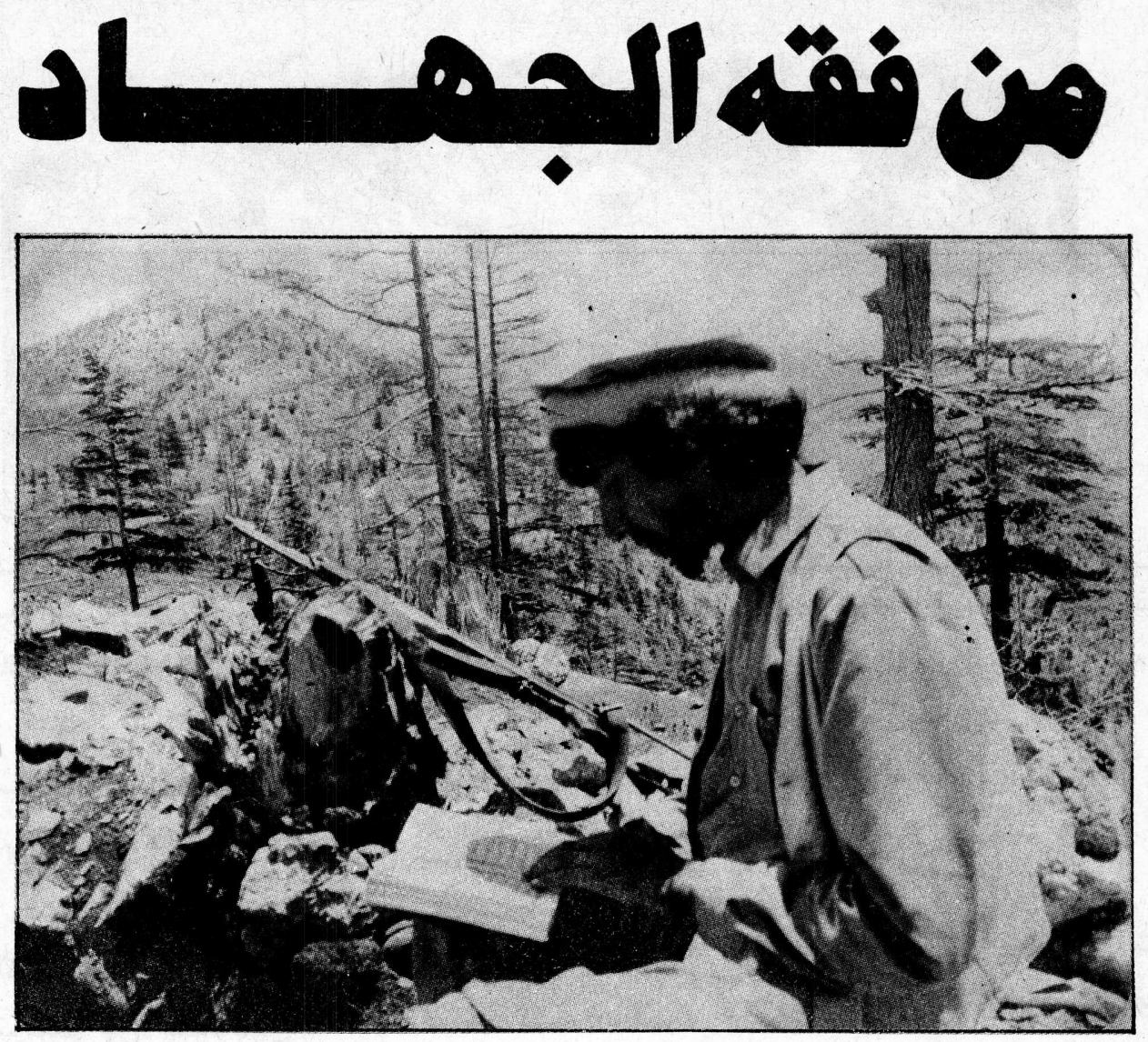

قال انمـا يتقتبل اللهه من ألمتتقين • لـئن

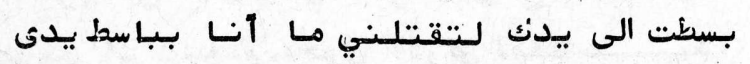

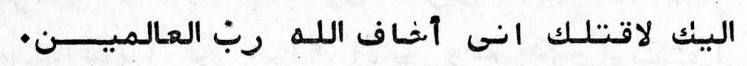

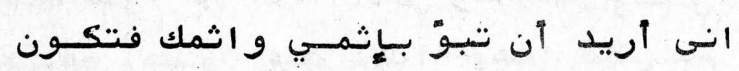

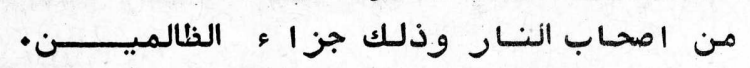

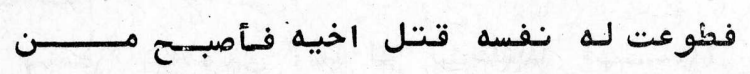

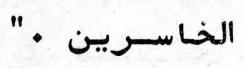

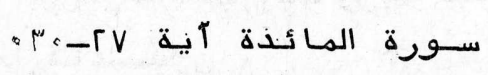

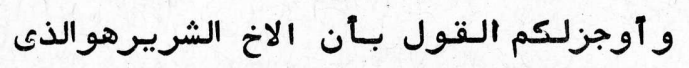

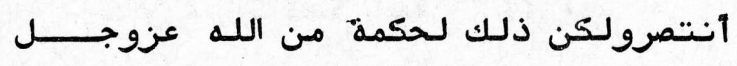

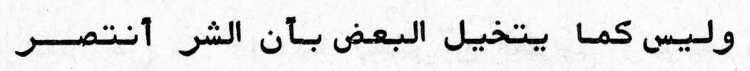

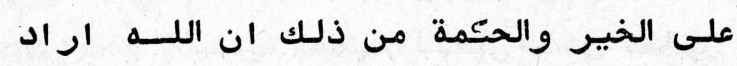

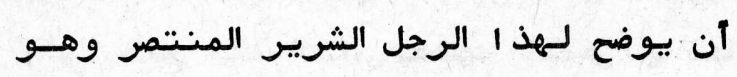

الفصل الاول : الف

تمههيد : الحمدلله ر رب العالمين والصـــــلاة

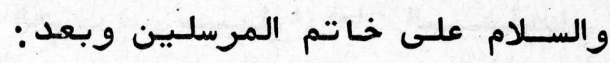

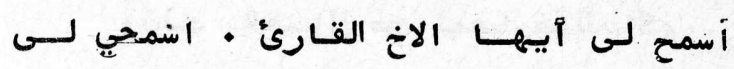

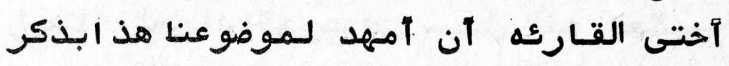

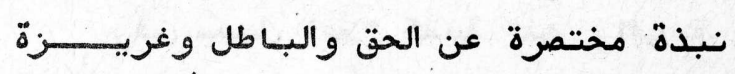

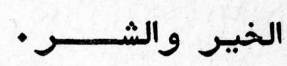

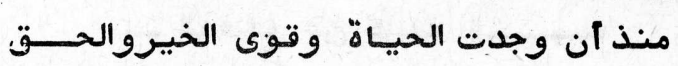

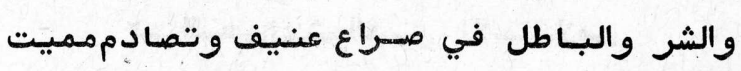

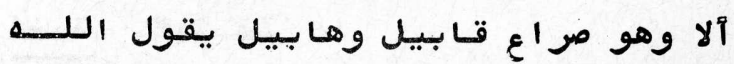

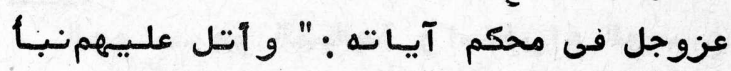

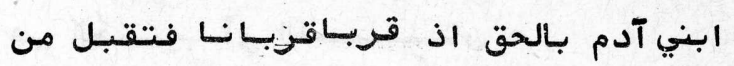

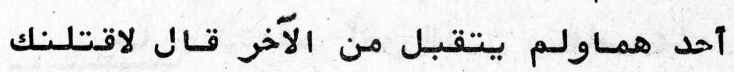

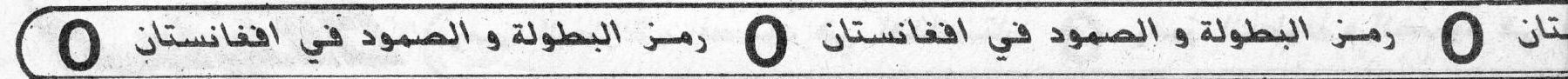




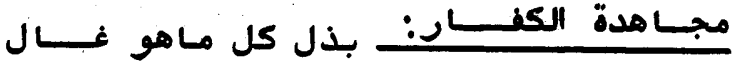
ونفيس فى سبيل اعلاء كلـمة اللهـ و أنتمبح

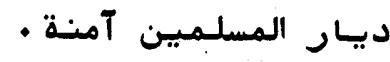

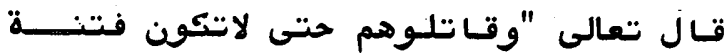

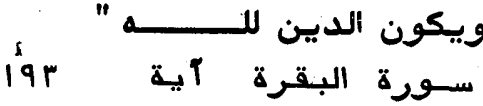

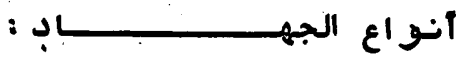

$$
\begin{aligned}
& \text { ا- الجهـاد بالم المبـل }
\end{aligned}
$$

قـل تعالى "انفروا خفـافـ وثقالاوجاهدو

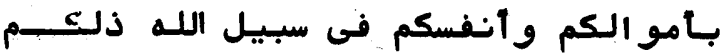

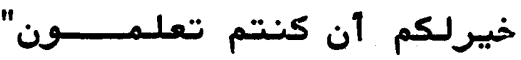

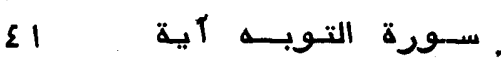

فالمسلمم القـادر بدنيـ وماليـ بيجهز نفسه

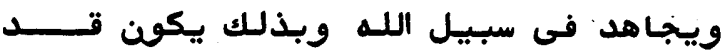

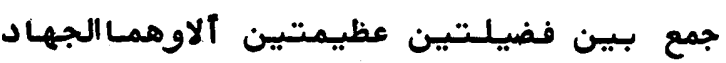
بالنفس والجهاد بالمنال وقديكون هنـاك مسلم عير قـادر بدنيا علبى الجهاد أو لاســـبـاب وفياب

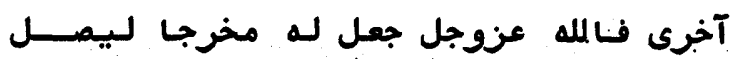

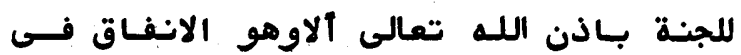
سبيـل الجهاد ومسـاعدة الاخوة المجاهــــين

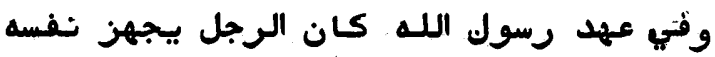

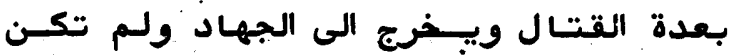
هنـاك رو اتب للجند .والقبادة انمـا كان عمسلا تطوغيـا بالنفس والمبال وهذ ا شأن العقيـدة

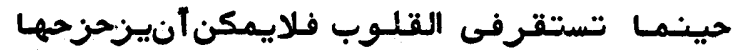

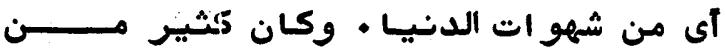

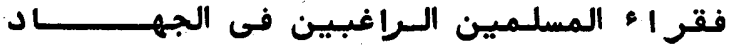
ورفع رايـة عقيدة التوحيد ربمـا لايجــون

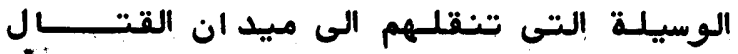
•أو شر ا • عدة القتشل فيذهبون لمرسول الله

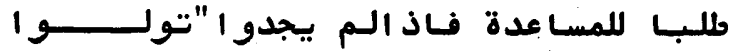

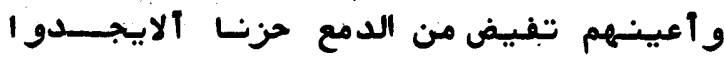

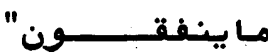

$$
\text { سـورة التوبـه آية }
$$

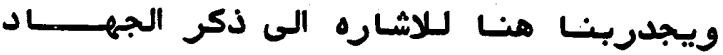

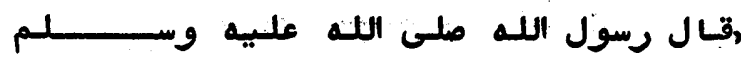

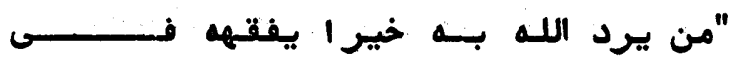

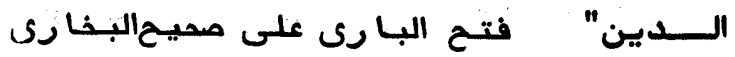
$17 \varepsilon \cdot 17 . / 1$

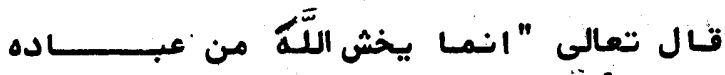

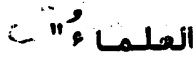

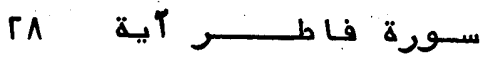

قال رسول الله ملـوات الله وسلامه علـيـــه

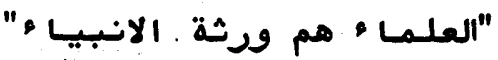

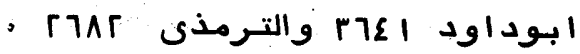

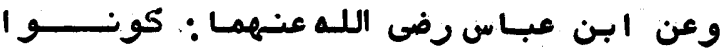

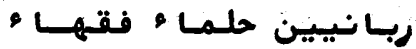
الــربـانى : الذى يربـى النـاسن بـفــار العلــم

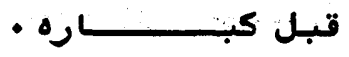
مجاهدة الشيطان : تجنب ودفع مـياتى به الشيطان من شبهـات ومـايزين من فو احســـــ

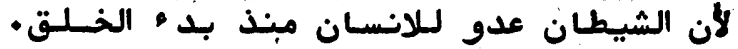

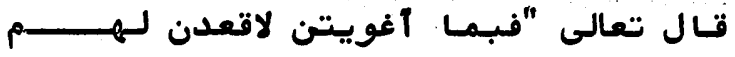

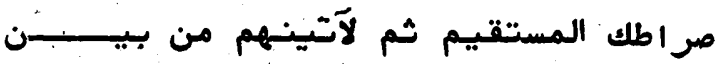

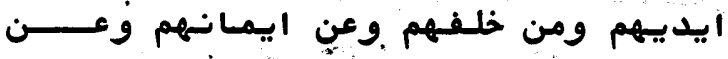

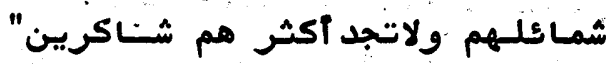

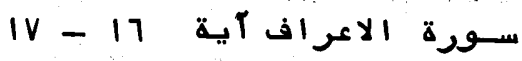
مجــهدة الفســـ : الامربالمعروف والنهـى عن المنكر و اجتنابه لـقول رسولنـالكريم ضلى الله علهيه وسلـم:

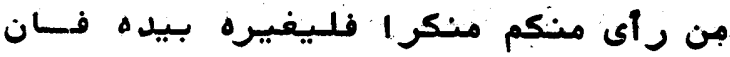

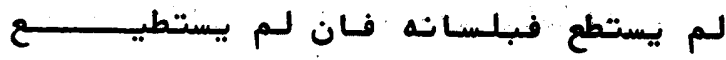

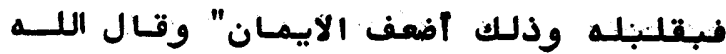

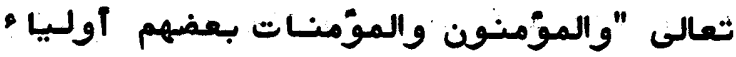
بعض يأمرون بالمعروف وينهون عن المنكــر ويقيمون الصلاة ويوتتون الزكاة ويطيعونالله

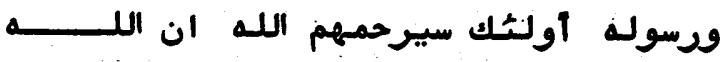

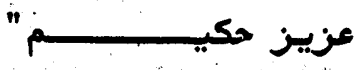

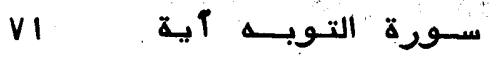


عنكريا تربويا تملنيميا وذلك لانن نحن

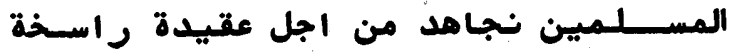

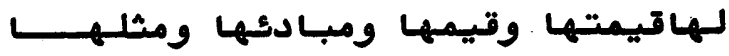

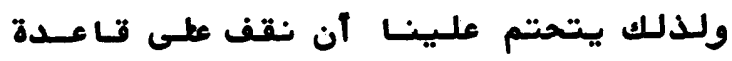

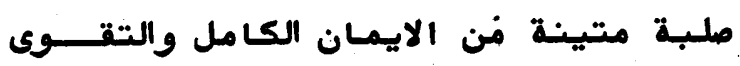

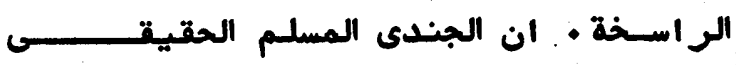

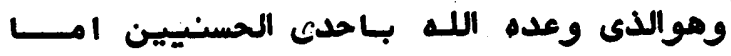

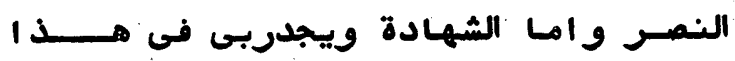

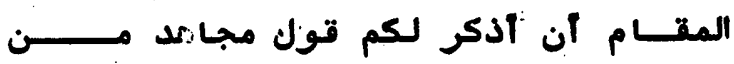

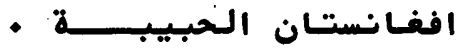

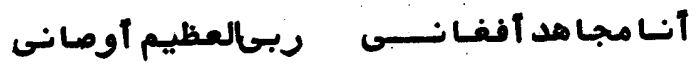

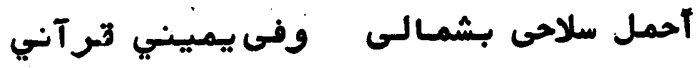

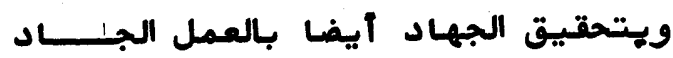

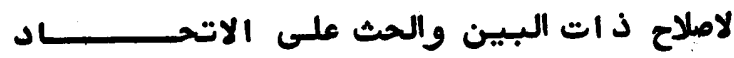

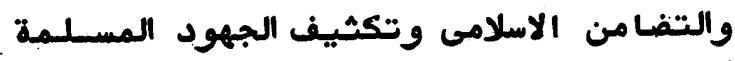

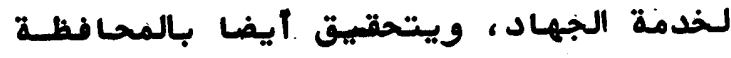

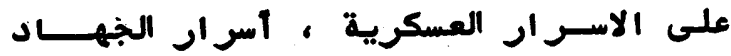

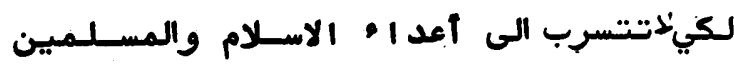
ويتحقق الجهاد بالتبرعبالمـال وكذلك بالدم

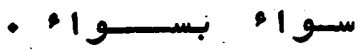

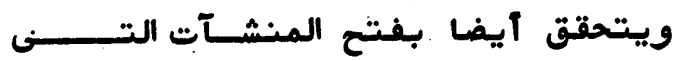

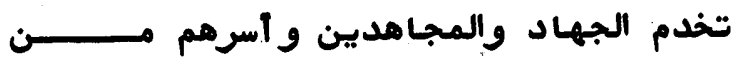

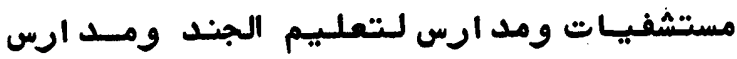

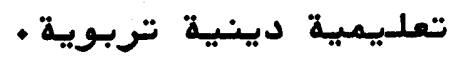

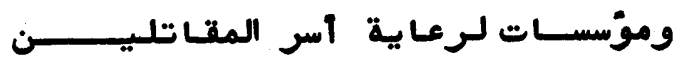

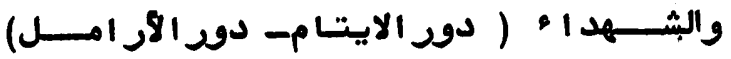
حتى يذهب المجامد يقـاتل وقد آيقن تمـاما

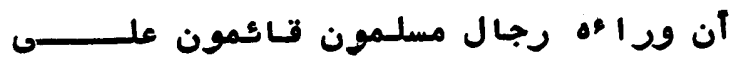

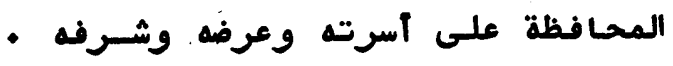

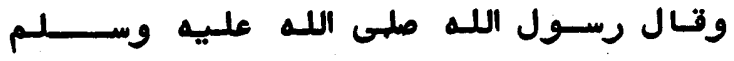

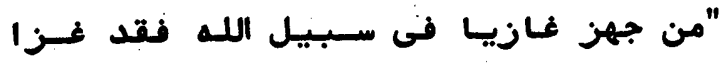

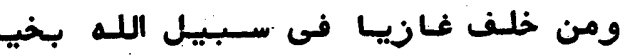

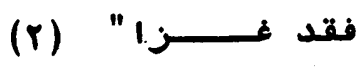

- 9r/1 مكيح البخـــ (1) (1)

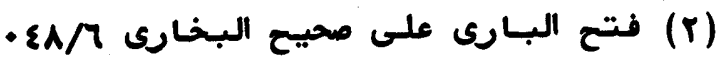

بالمال قبل غيره من انواع الجهاد وذلــك

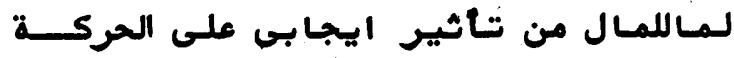

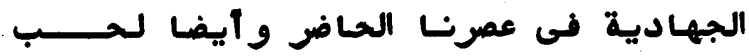
المـال والبخل فى اخر اجه ولبوكان فى سبيل وفيل

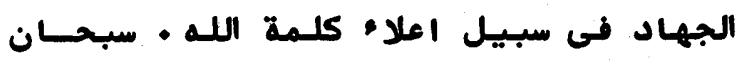

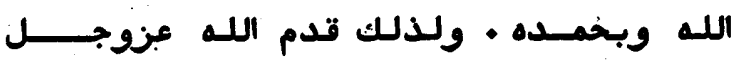
المـال على النفس فى الايـة الكريمة "وجـاهدوا بـأمو الكم وأنفسكم" وقدم المـال على الابن

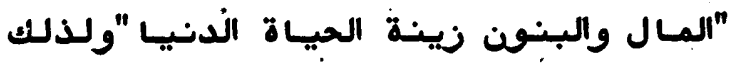

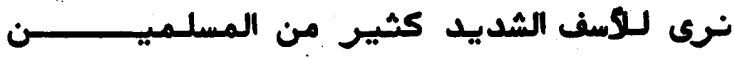

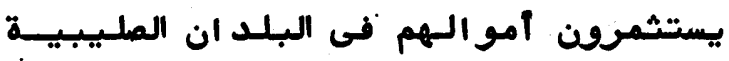

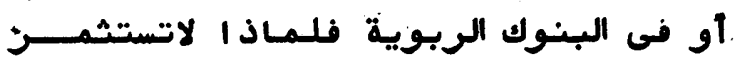

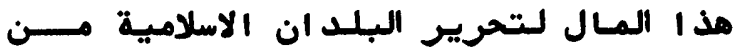
الطواغيت إع لورفع راية التوحيد عالـيـة

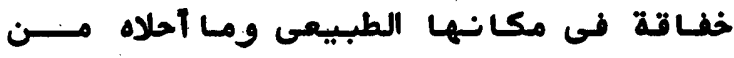

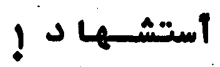

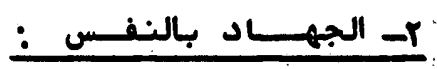

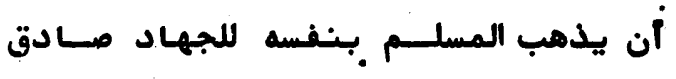

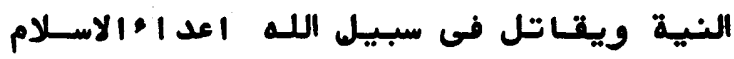

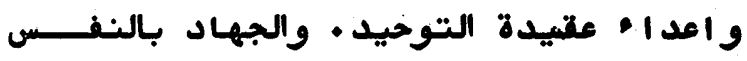

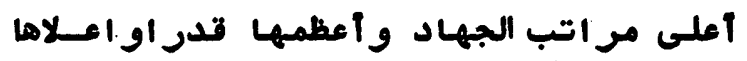
ثـانــا وهل يملك الانبسان أغلى من اعن روحسه

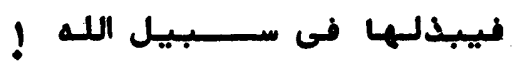

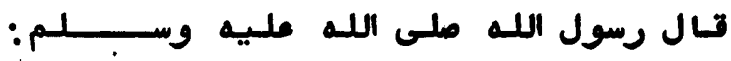

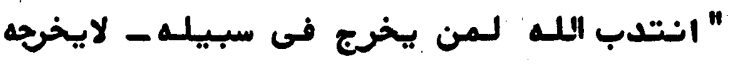

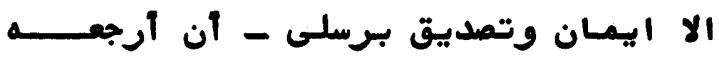

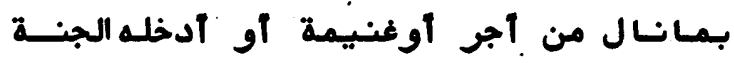

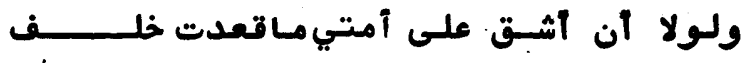

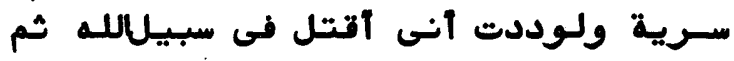

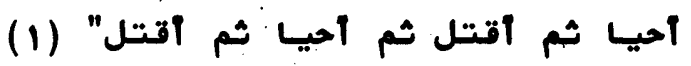

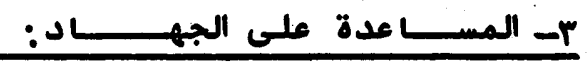
وذلك بـالاسـهـام فى كل عمل من شنانــه

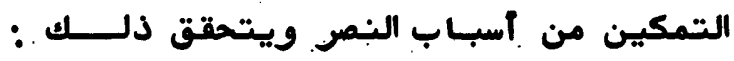

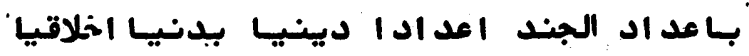




\section{اضواءعلىفتح

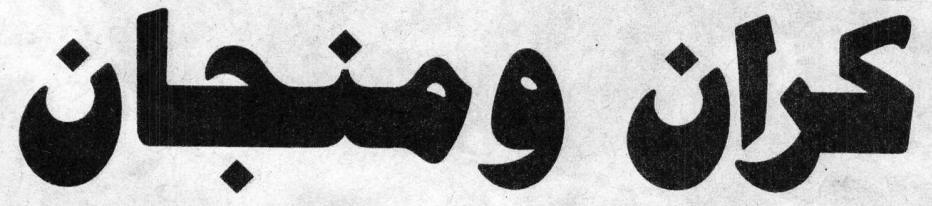

هذه الطر ق الثي نللت مفلـقة أمـامالمجاهدين

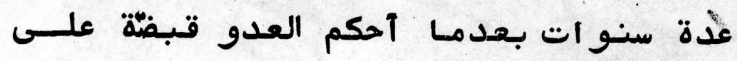

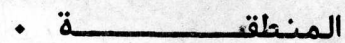

لـقدكان على المجاهدين في. السابتق آن

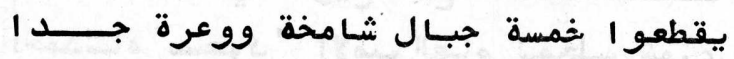

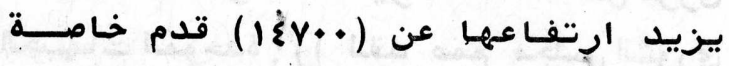

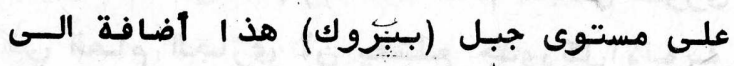

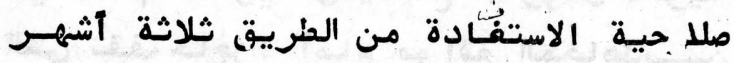
فقط هلول السنة لانهيا تنلل مغطساة بالثلـوج

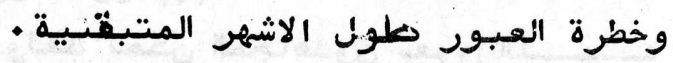

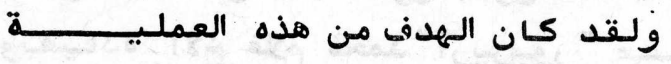

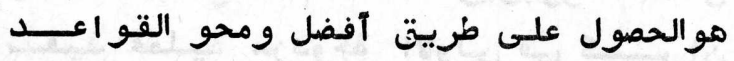

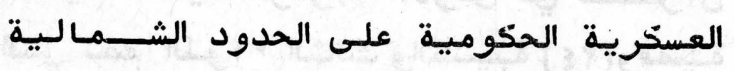

أفـادت التقـارير التي وردت من مجلـــس

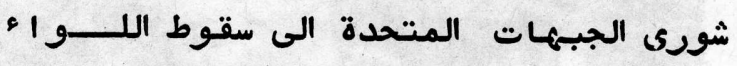

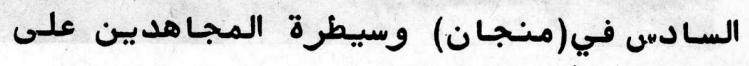

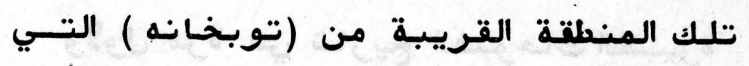

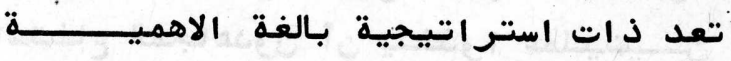

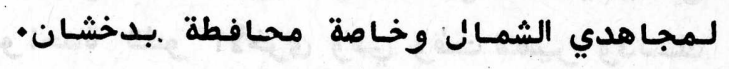

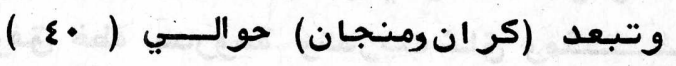

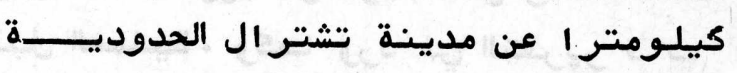

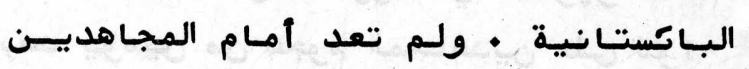

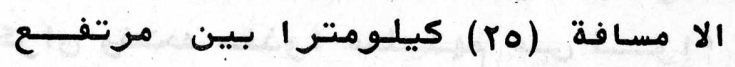

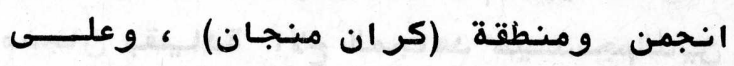

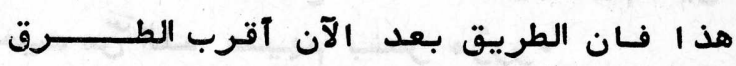

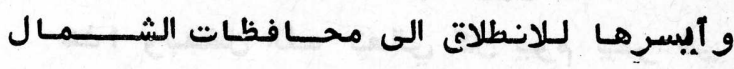

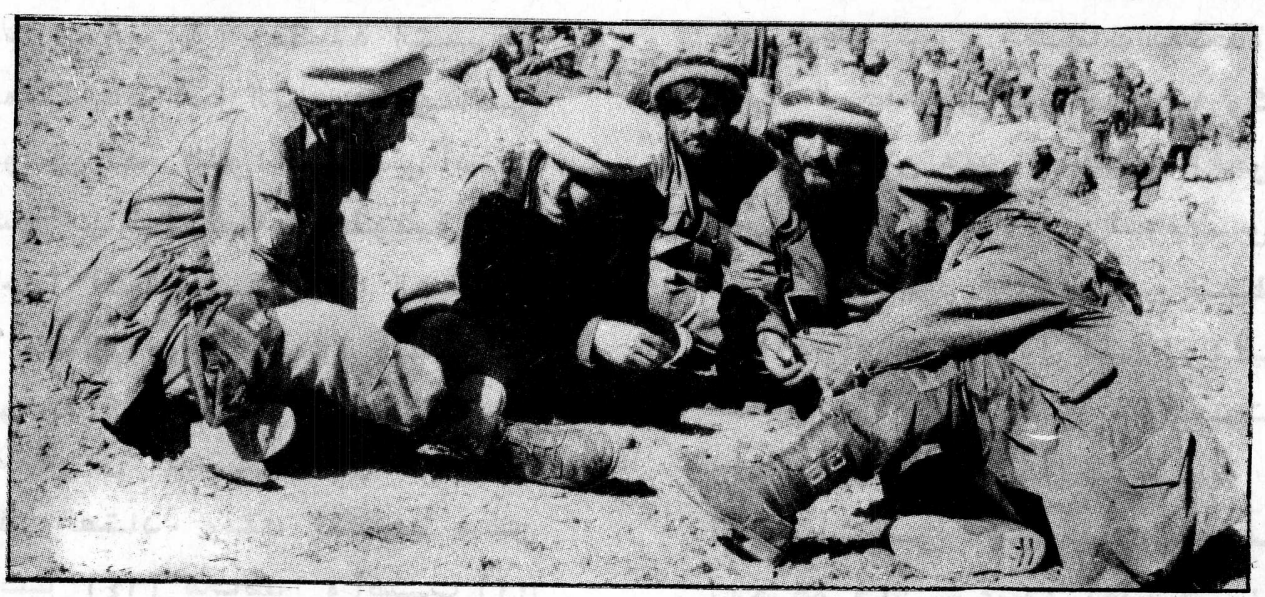

قـادة فتح كر ان في جلسة .تخطيط العملـية قبل بدأ السهجوم

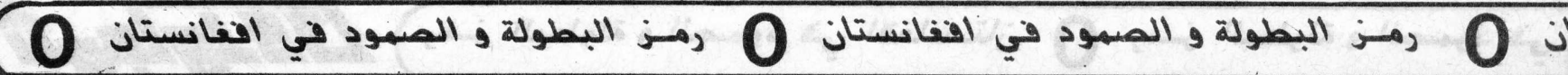



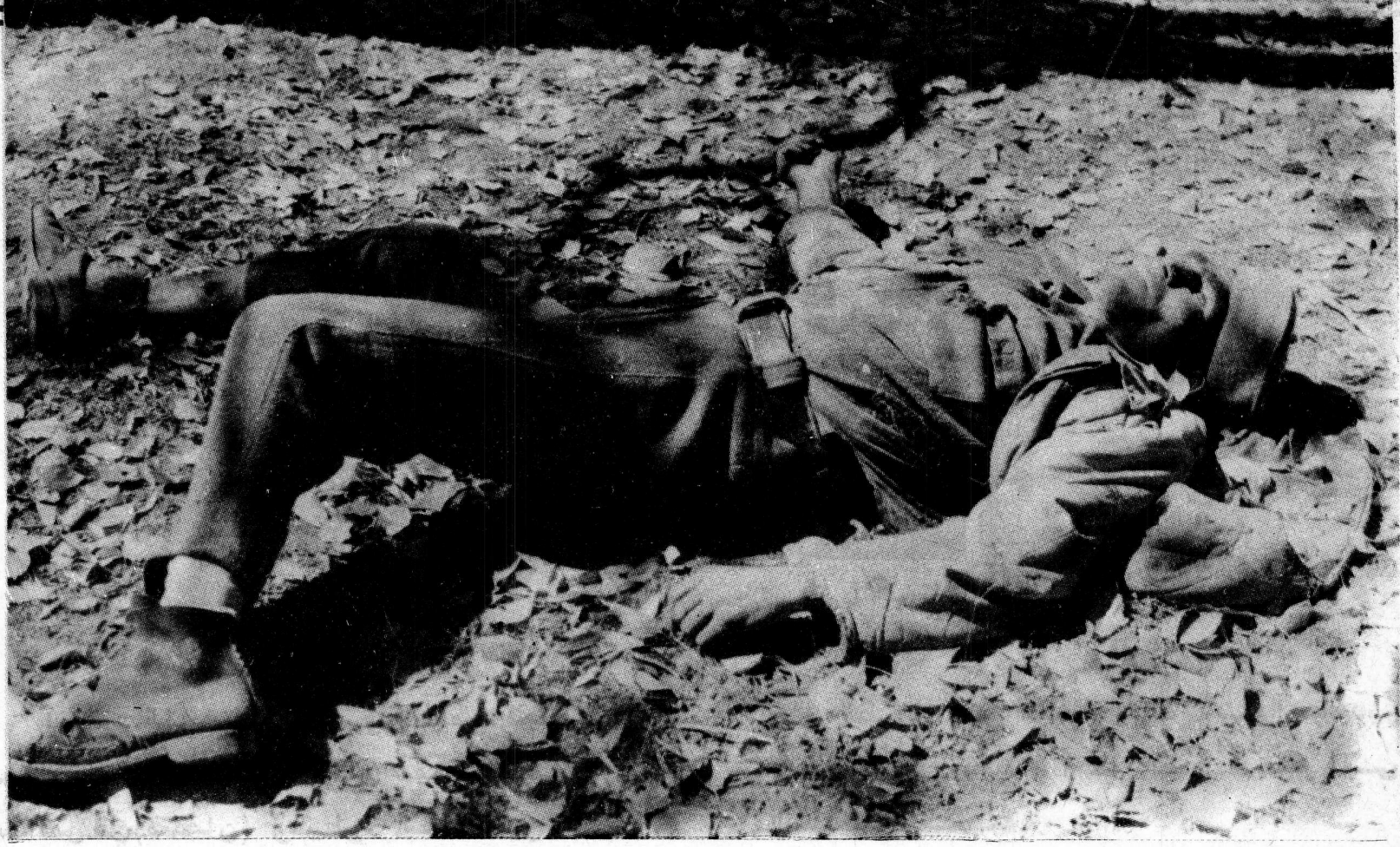

ولأول مرة في تـاريخ الفتوحسات الكبيزة

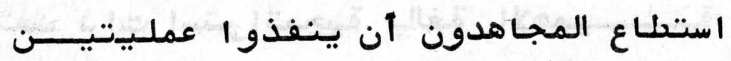

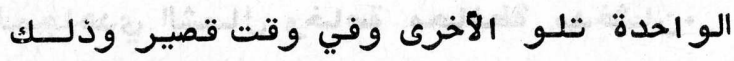

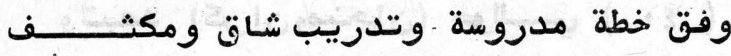

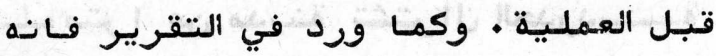

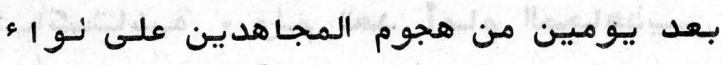

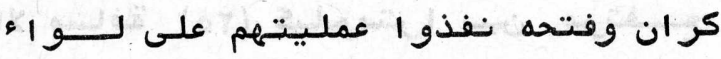

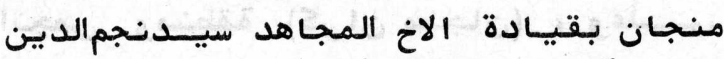

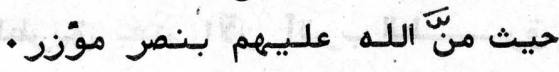

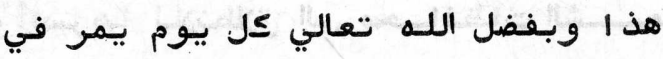

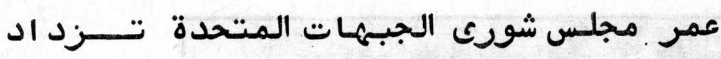

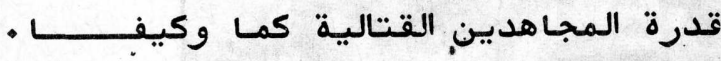
فبـالأمس كان عسير ا عليهم الهجومو الاستيلاو

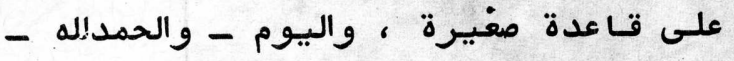

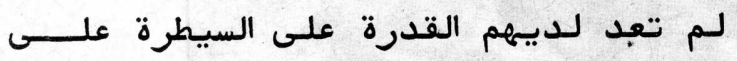

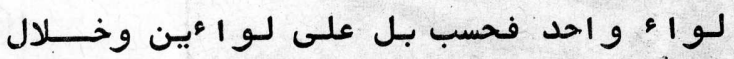

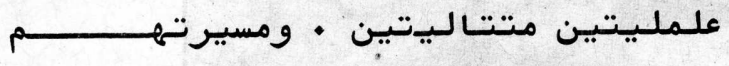

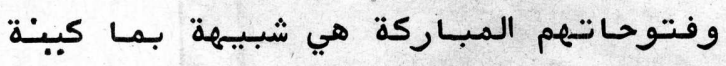

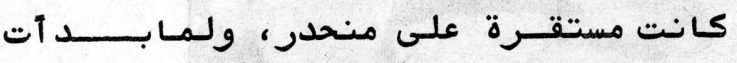

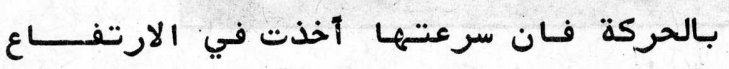

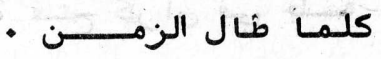

مثلـمـا جـاء في تصريح الاخ القـاء

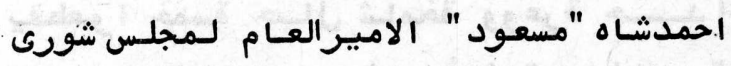
الجبهـات الموحدة : ( ( لـقد صمم مجلس الشورى الامير

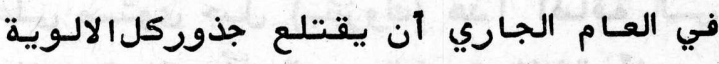

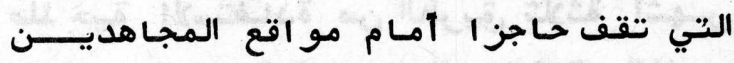
- ال

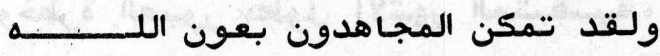

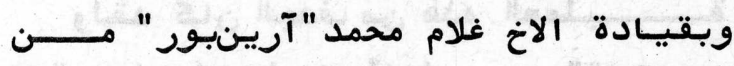

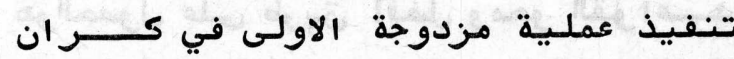

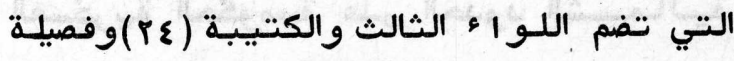

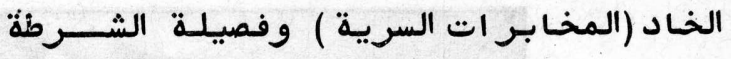

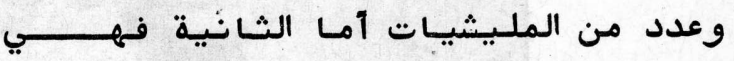

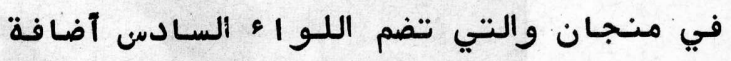

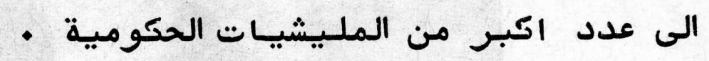

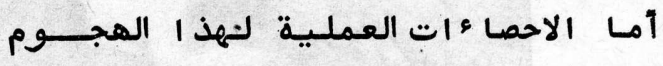

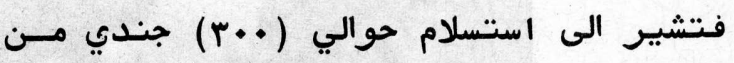

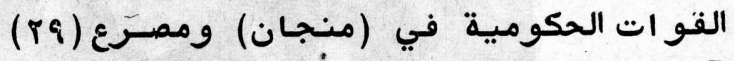

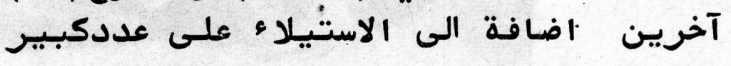

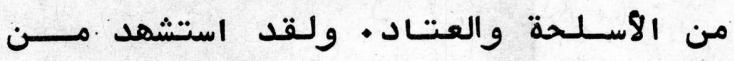

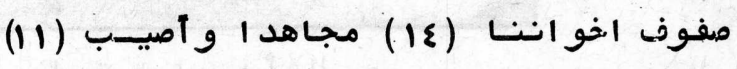
- آخرين بهوف 


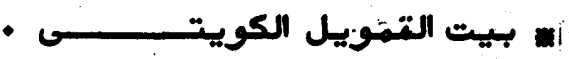

-

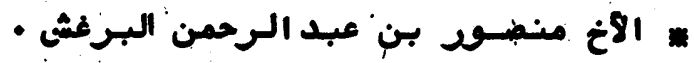

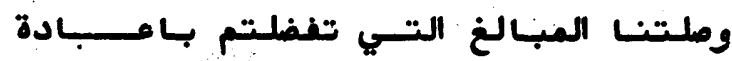

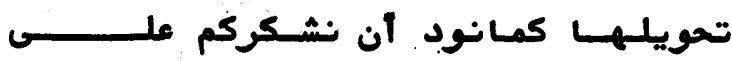

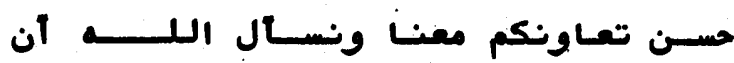
يجسازيكم عنـاوعن الإسـلام كل خير ونمير : الاخسوة الكرام في مجلة الامسلاح المغـــرب

تم تسجيل عنوان مؤسســـــم ضمن زميلاتها

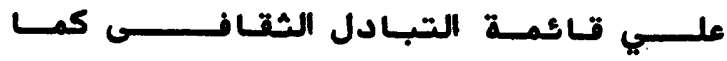

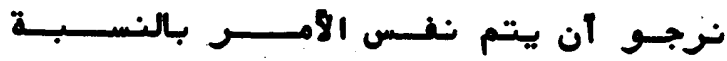
- لـمجلتنــان

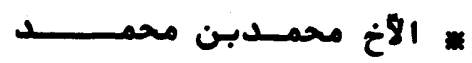

\section{هولن.}

نرجو أن تتففـل بـارسال قيمة الاشتتـر اك

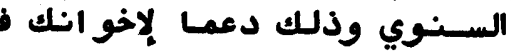

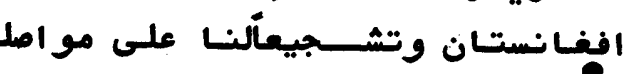

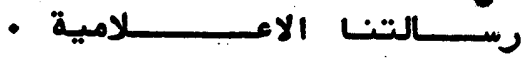

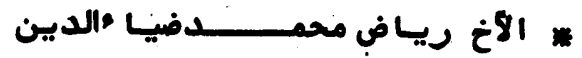

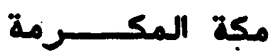

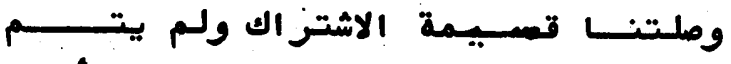

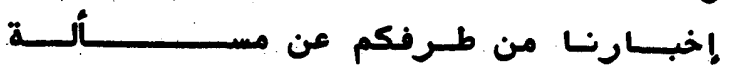

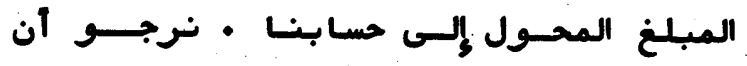

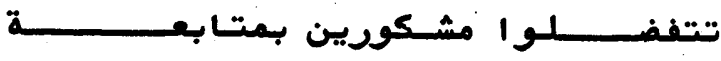

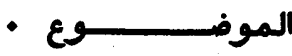

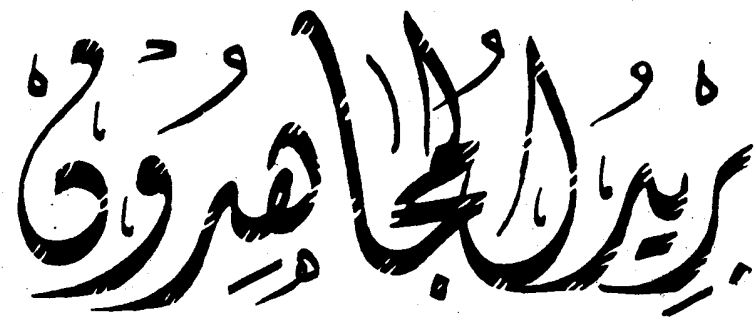

\%

فير نســـ

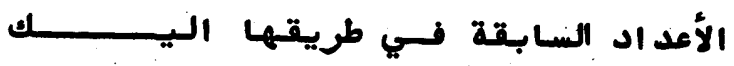

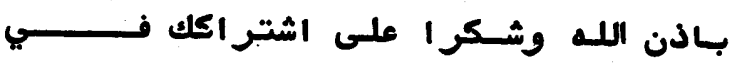
- لـ

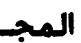

$$
\text { • • }
$$
الجـــــــ

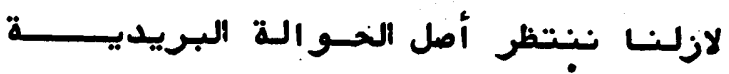

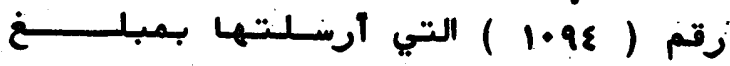
( lor.r. )

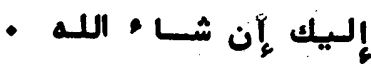

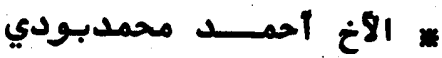

$$
\begin{aligned}
& \text { الكــــويت }
\end{aligned}
$$
* المملكة .العربيةالسعودية

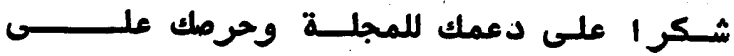

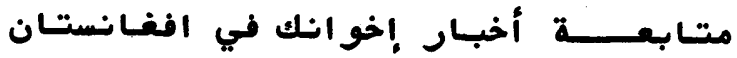

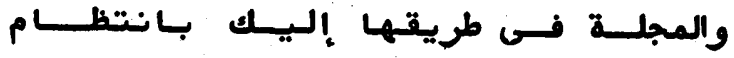

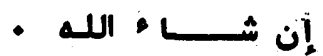

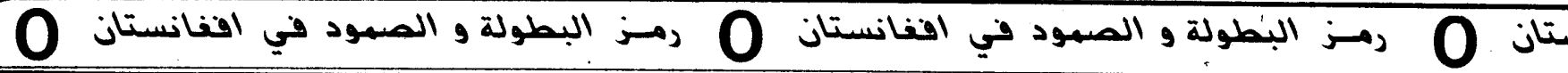



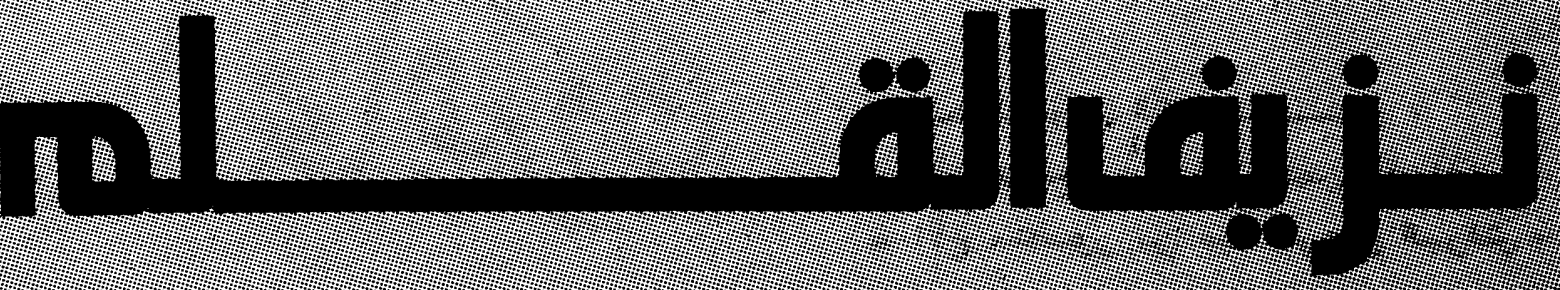

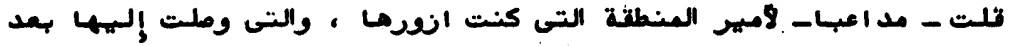

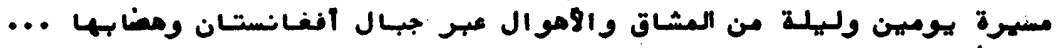

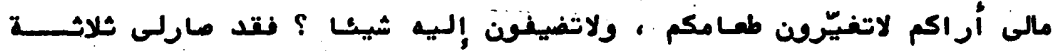

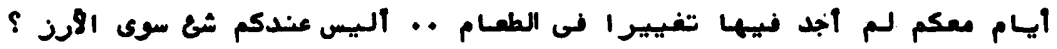

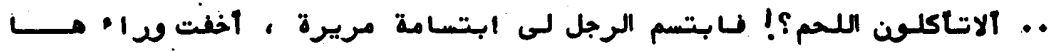

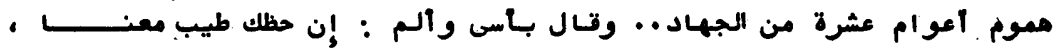

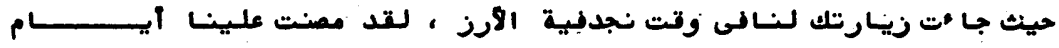

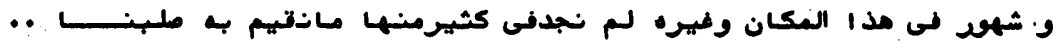

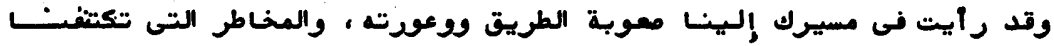

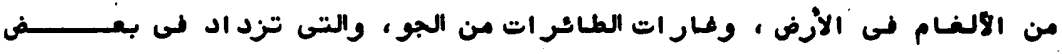

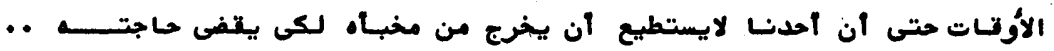

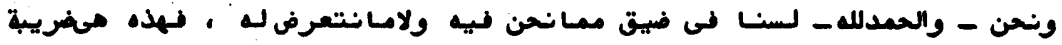

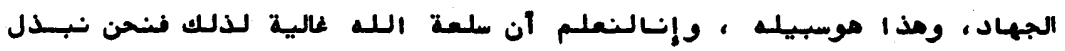

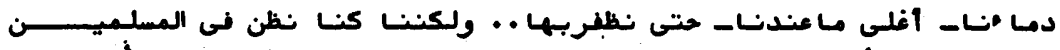

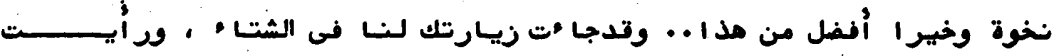

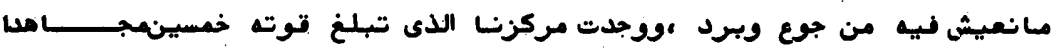

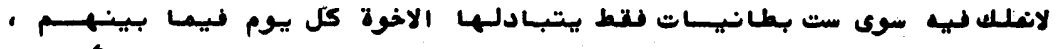

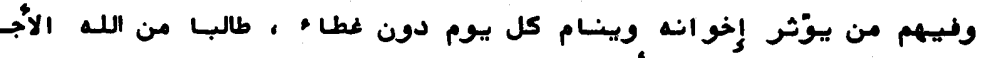

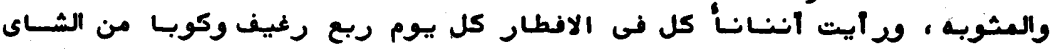

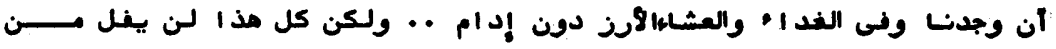

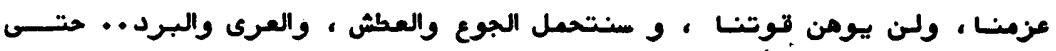

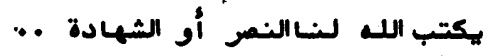

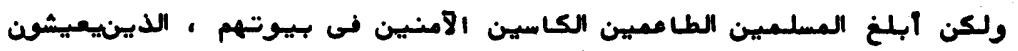

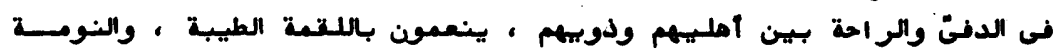

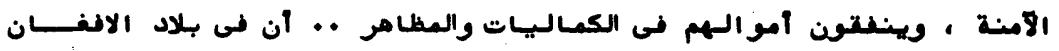

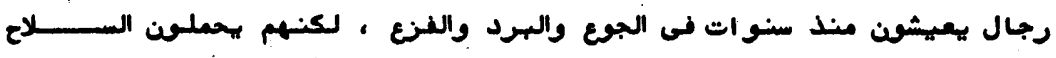

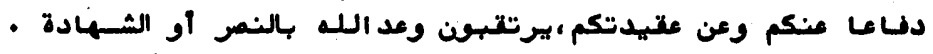
لهان أفقتم من سباتكم وعرفتم واجبهم عليكم فهو حقهم عليكم ويخلفهالله

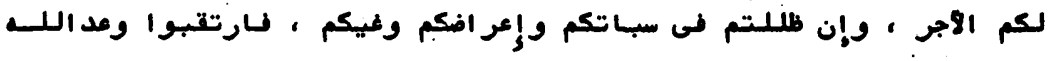
- وجس

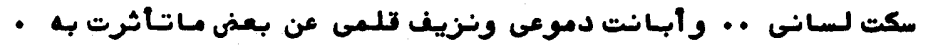

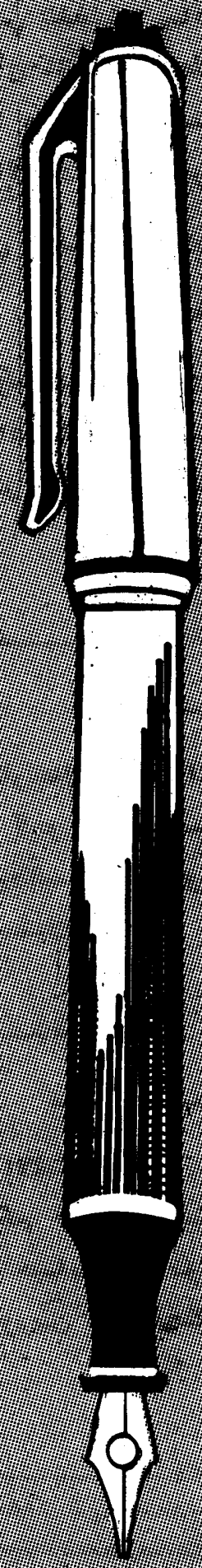


clew|X|
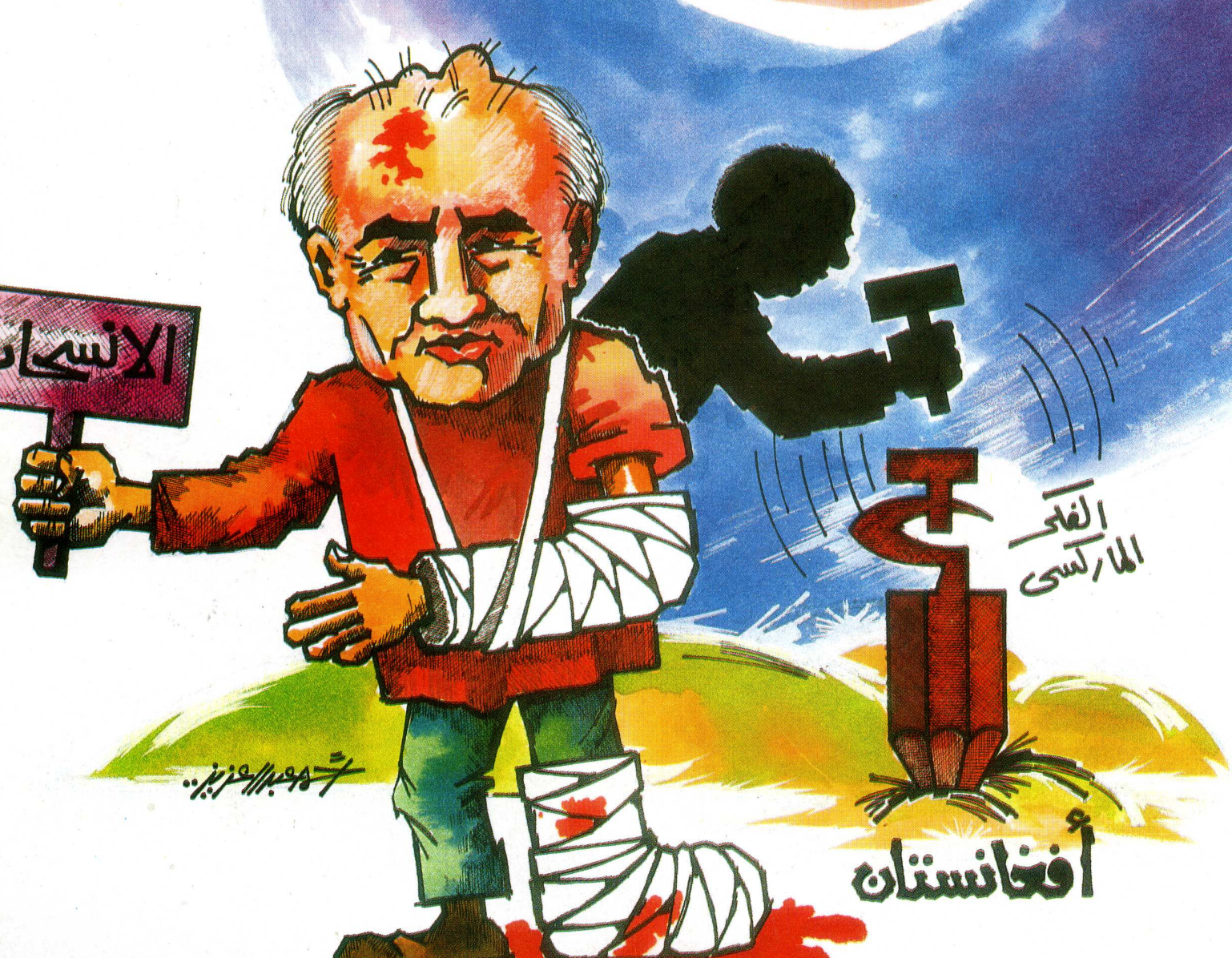

$4+2$ (a) 


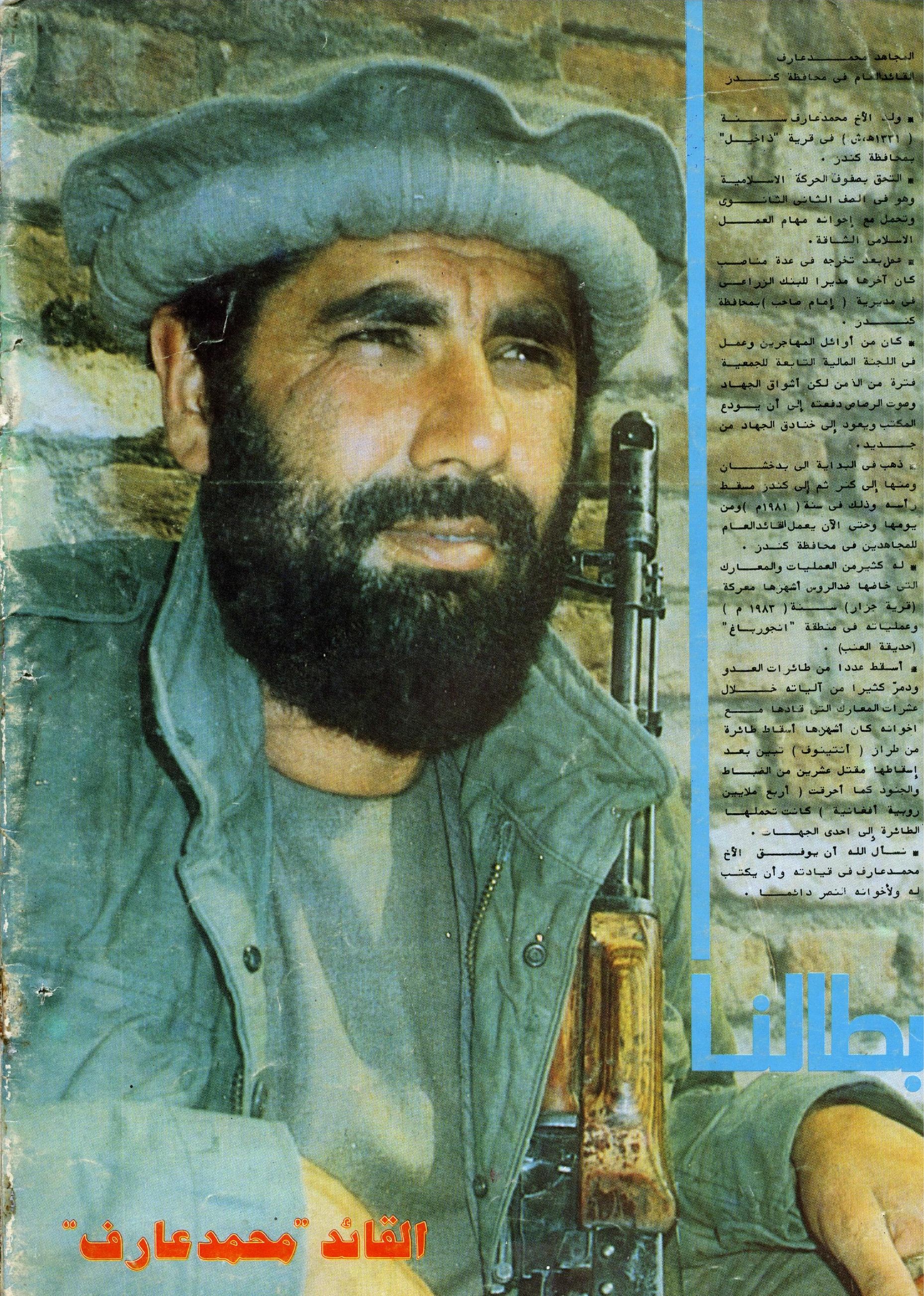

